\title{
BASALT PETROGENESIS BENEATH SLOW- AND ULTRASLOW- SPREADING ARCTIC MID-OCEAN RIDGES
}

\author{
By \\ Lynne J. Elkins \\ M.S. Earth and Planetary Science, University of New Mexico, 2003 \\ B.A. Geology, Smith College, 2001 \\ Submitted in partial fulfillment of the requirements for the degree of \\ Doctor of Philosophy \\ at the \\ MASSACHUSETTS INSTITUTE OF TECHNOLOGY \\ and the \\ WOODS HOLE OCEANOGRAPHIC INSTITUTION
}

February 2009

(C) 2009 Lynne J. Elkins

All rights reserved.

The author hereby grants to MIT and WHOI permission to reproduce and to distribute publicly paper and electronic copies of this thesis document in whole or in part in any medium now known or hereafter created.

Signature of Author

Joint Program in Marine Geology and Geophysics Massachusetts Institute of Technology and Woods Hole Oceanographic Institution

Certified by January 5, 2009

\section{Accepted by}

Dr. Kenneth W. W. Sims, Thesis Supervisor

Dr. Bradford H. Hager

Co-Chair, Joint Committee for Marine Geology and Geophysics Massachusetts Institute of Technology/

Woods Hole Oceanographic Institution 


\title{
BASALT PETROGENESIS BENEATH SLOW- AND ULTRASLOW- SPREADING ARCTIC MID-OCEAN RIDGES
}

By

\author{
LYNNE J. ELKINS
}

Submitted to the Joint Committee for Marine Geology and Geophysics on December 19, 2008 in partial fulfillment of the requirements for the Degree of Doctor of Philosophy

\begin{abstract}
To explore the ability of melting mafic lithologies to produce alkaline ocean-island basalts (OIB), an experimental study was carried out measuring clinopyroxene (Cpx)melt and garnet (Gt)-melt partition coefficients during silica-poor garnet pyroxenite melting for a suite of trace elements, including $\mathrm{U}$ and $\mathrm{Th}$, at $2.5 \mathrm{GPa}$ and $1420-1450^{\circ} \mathrm{C}$. Partition coefficients range from $0.0083 \pm 0.0006$ to $0.020 \pm 0.002$ for Th and $0.0094 \pm 0.0006$ to $0.024 \pm 0.002$ for $U$ in $C p x$, and are $0.0032 \pm 0.0004$ for Th and $0.013 \pm 0.002$ for $U$ in Gt. Forward-melting calculations using these experimental results to model time-dependent uranium-series isotopes do not support the presence of a fixed quantity of garnet pyroxenite in the source of OIB.
\end{abstract}

To use U-series isotopes to further constrain mantle heterogeneity and the timing and nature of melting and melt transport processes, U-Th-Pa-Ra disequilibria, radiogenic isotopes, and trace-element compositions were measured for the slow-spreading Arctic mid-ocean ridges (MOR). A focused case study of 33 young $(<10 \mathrm{ka})$ MOR basalts (MORB) from the shallow endmember of the global ridge system, the Kolbeinsey Ridge $\left(67^{\circ} 05^{\prime}-70^{\circ} 26^{\prime} \mathrm{N}\right)$ found that unaltered Kolbeinsey MORB have universally high $\left({ }^{230} \mathrm{Th} /{ }^{238} \mathrm{U}\right)(1.165-1.296)$ and relatively uniform $\left({ }^{230} \mathrm{Th} /{ }^{232} \mathrm{Th}\right)(1.196-1.324), \varepsilon_{\mathrm{Nd}}(8.43-$ 10.49), ${ }^{87} \mathrm{Sr} /{ }^{86} \mathrm{Sr}(0.70274-0.70301), \varepsilon_{\mathrm{Hf}}(16.59-19.56)$, and $\mathrm{Pb}$ isotopes (e.g. ${ }^{208} \mathrm{~Pb} /{ }^{206} \mathrm{~Pb}=$ 2.043-2.095). This suggests a homogeneous mantle source and a long peridotite melting column produces the thick Kolbeinsey crust. Trace element ratios suggest a young, 
depleted mantle source. Data from the slow- to ultraslow Mohns and Knipovich Ridges north of Kolbeinsey form a sloped array, and $\left({ }^{230} \mathrm{Th} /{ }^{232} \mathrm{Th}\right)$ correlates systematically with radiogenic isotopic variations. These data are readily reproduced by models for heterogeneous mantle melting. MORB from $85^{\circ} \mathrm{E}$ on the global ultraslow-spreading endmember Gakkel Ridge are homogeneously depleted with low $\left({ }^{230} \mathrm{Th} /{ }^{238} \mathrm{U}\right)$ and high $\left({ }^{226} \mathrm{Ra}{ }^{230} \mathrm{Th}\right)$ that lie along a global negative correlation. Arctic data support a global mantle temperature control on mean $\left({ }^{230} \mathrm{Th} /{ }^{238} \mathrm{U}\right)$.

Thesis Supervisor: Dr. Kenneth W. W. Sims

Title: Associate Scientist with Tenure 


\section{ACKNOWLEDGMENTS}

My deepest thanks, first and foremost, must go to Ken Sims, who taught me so much of what I know about mid-ocean ridge basalts, uranium-series chemistry, sample preparation, and thinking like a scientist. Ken was the most attentive and caring advisor, checking on me regularly to keep me on task and check in, but letting me take time to myself (and telling me to take vacations) when I needed it. Ken sent me all over the world to learn techniques in the best places from some of the best scientists, he challenged me to think things through, and he made sure I always had the resources I needed to excel. I could never have hoped for a more thoughtful, caring mentor.

Glenn Gaetani taught me, step by patient step, how to construct and run my own pistoncylinder experiments. Glenn always had words of encouragement to keep me going despite all the difficult failures experimental work can sometimes entail. I got to see firsthand how methods are tested and developed in an experimental lab, and take part in that process. It was an invaluable learning experience, and it has left me with admiring respect for those lifelong experimentalists who love unwrapping their presents after an experiment is done, and who don't mind taking the occasional shower in coolant or finding anti-seize on the back of their elbow in bed at night.

I also want to thank the rest of my committee. Fred Frey, my advisor at MIT, was there to teach me and help me think critically about my research throughout my time in the Joint Program. Jian Lin, from Geodynamics project advisor to exam committee chair to a thesis committee member, provided guidance and always reminded me to think beyond chemistry to the big picture questions involved. Peter Kelemen was always excited to talk about Kolbeinsey data and to share his innovative ideas, and he challenged me in committee meetings to think about everything in more depth. Susan Humphris was not just a fantastic, fair, and insightful chair, but she was a wonderful resource when I needed input or advice on anything, from research to my career.

I need to include a lot of thanks for my many collaborators on these research projects. I'm very grateful to Susan and to Rob Sohn for bringing me on board for the AGAVE project on the Gakkel Ridge. It was a fantastic opportunity to study some very exciting rocks. Jean-Guy Schilling literally opened the door to his large and extensive sample collection so that I could take whatever I needed for my research. Colin Devey invited me to attend a R/V Poseidon cruise to the Tjornes Fracture Zone, so that I got to see my field site firsthand and sample it myself, and he let me come to Kiel to take any samples I needed from their large Kolbeinsey sample collection. He has continued to work with me on finding old cruise reports, rounding up data, and discussing results. Susanne Fretzdorff and Karsten Haase were extremely generous in sharing both data and feedback.

In 2005 I visited the lab of Janne Blichert-Toft in Lyon, to learn how to measure Hf and $\mathrm{Nd}$ isotopes. Janne and I immediately connected, and I consider her one of the most important mentors I have ever had. I arrived in France burnt out and exhausted after my 
exams, and I left excited and fired up about my science all over again. Janne's continuing support and kind words over the years have been one of the biggest things that kept me going along the way. My warmest gratitude to her for everything.

I was able to visit Tim Elliott's lab in Bristol, and to discuss my ideas and data with him over the years that have followed. He and Julie Prytulak taught me to measure $\mathrm{Pa}$ isotopes - no easy task! Julie followed up by re-measuring many samples herself when we encountered analytical problems, something for which I am extremely grateful. I have been so lucky to have the opportunity to collaborate with such brilliant scientists.

Jurek Blusztajn taught me to measure $\mathrm{Sr}, \mathrm{Pb}$, and $\mathrm{Nd}$, helped me in the lab countless other times, and in the end analyzed some of my samples himself as a collaborator. As a colleague in the lab, and on the mass spectrometer this past year, Jurek was always an invaluable resource. He is always optimistic, cheerful, and helpful.

The Joint Program has given me many opportunities to travel to exciting places (Hawaii, Canada, Costa Rica), and has funded my travel to the cruise in Iceland as well as scientific meetings as far away as San Francisco and Melbourne, Australia. The Academic Programs Office was always there when I needed advice or help, especially Julia and Marsha.

My fellow students were one of the main things that kept me going through the years. My classmates from other departments that I saw over the years, housemates like Chris and Joanna, and fellow G\&G students like Matt, Trish, and others were always great to talk to and spend time with. Sharon Hoffmann gets a very special thank you, for putting up with me and sticking with me in small, shared offices for nearly 5 years, and for all around being my best JP buddy. Another special thanks goes to Chris and Evy, my fellow labgroup-mates, for all of the shared advice, feedback, and good times. And a big thank you is owed to Brian deMartin. From driving to Maine to rescue me, to playing video games, going out to breakfast, and building lego tie-fighters together during tough times, Brian made sure I was always able to laugh about things. Getting here would have been a whole lot tougher without his help.

I clearly could not have done any of this without my family's unswerving support. My mom, who talked me out of giving up more times than I can count; my dad, for his steadiness and support; and my sister and brothers for keeping me grounded and always being there over the years.

This work was made possible through funding support from the National Defense Science and Engineering Graduate Fellowship Program, from the Academic Programs Office, from the WHOI and MIT student travel assistance funds, and from National Science Foundation grant OCE-0422278 to K.W.W.S. 


\section{CONTENTS}

$1 \quad$ Introduction 9

2 Partitioning of $U$ and $T h$ during garnet pyroxenite partial melting:

Constraints on the source of alkaline ocean island basalts 20

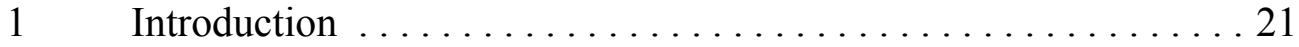

2 Experimental and analytical techniques $\ldots \ldots \ldots \ldots \ldots 22$

$2.1 \quad$ Starting materials. . . . . . . . . . . . 22

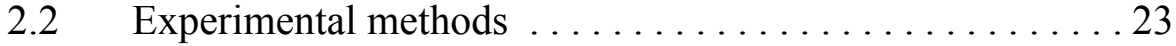

2.3 Analytical methods ................ 23

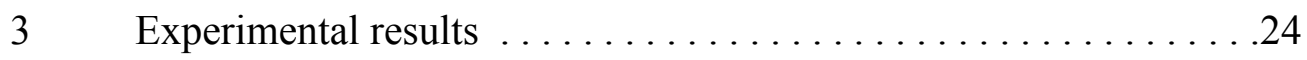

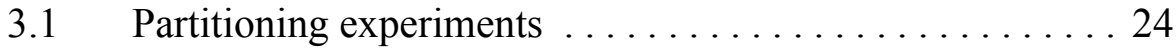

3.2 Approach to equilibrium $\ldots \ldots \ldots \ldots \ldots \ldots$

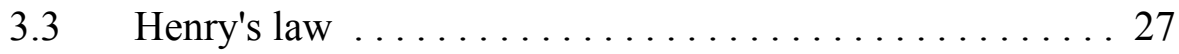

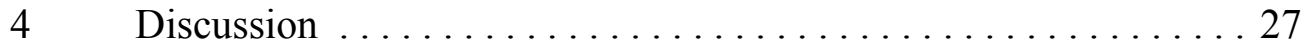

4.1 Partitioning of $U$ and Th during partial melting of garnet pyroxenite $\ldots \ldots \ldots \ldots \ldots \ldots \ldots \ldots \ldots \ldots \ldots \ldots \ldots \ldots \ldots \ldots \ldots \ldots$

4.2 Uranium series constraints on the role of garnet pyroxenite

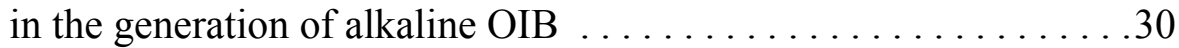

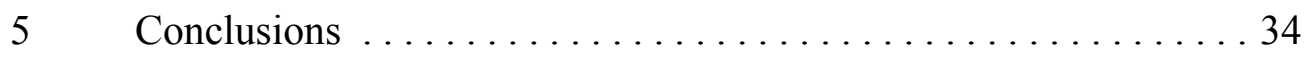

Appendix ............................

3 Melt generation and magma transport rates beneath the slow spreading

Kolbeinsey Ridge determined from ${ }^{238} \mathrm{U},{ }^{230} \mathrm{Th}$, and ${ }^{231} \mathrm{~Pa}$ excesses 39

3.1 Introduction $\ldots \ldots \ldots \ldots \ldots \ldots \ldots \ldots \ldots \ldots \ldots \ldots \ldots \ldots \ldots$

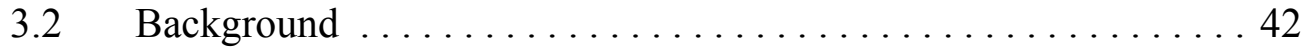

3.2 .1 Geological Setting $\ldots \ldots \ldots \ldots \ldots \ldots \ldots \ldots \ldots \ldots \ldots \ldots \ldots \ldots$

3.2 .2 Age Constraints ................... 44

3.2.3 Chemical and Isotopic Compositions . . . . . . . . . . . 49

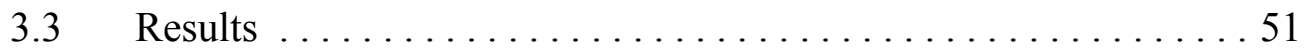

3.3.1 U-Series Disequilibria in Kolbeinsey Ridge Basalts . . . . . 51 
3.3.1.1 ${ }^{238} \mathrm{U}_{-}^{234} \mathrm{U} \ldots \ldots \ldots \ldots \ldots \ldots \ldots \ldots \ldots . \ldots . \ldots . \ldots 52$

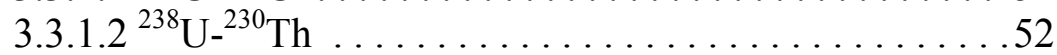

3.3.1.3 ${ }^{238} \mathrm{U}^{231} \mathrm{~Pa} \ldots \ldots \ldots \ldots \ldots \ldots \ldots \ldots \ldots \ldots$

3.3.2 Radiogenic Isotope Results $\ldots \ldots \ldots \ldots \ldots \ldots \ldots 61$

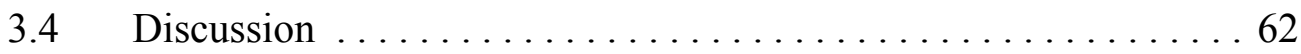

3.4.1 Shallow Alteration $\ldots \ldots \ldots \ldots \ldots \ldots \ldots \ldots . \ldots 62$

3.4.2 Modeling the Horizontal Kolbeinsey Array . . . . . . . . 64

3.4.2.1 Time-Independent Melting . . . . ........ 65

3.4.2.2 Dynamic and Reactive Porous Flow Melting .... 70

3.4.3 Global ${ }^{230} \mathrm{Th}^{238} \mathrm{U}$ Disequilibria, Spreading Rates, and

Axial Depth ........................... 75

3.5 Conclusions $\ldots \ldots \ldots \ldots \ldots \ldots \ldots \ldots \ldots \ldots \ldots \ldots \ldots \ldots$

Appendix ................................ 87

4 Generation of ${ }^{226} \mathrm{Ra},{ }^{238} \mathrm{U}$, and ${ }^{230} \mathrm{Th}$ excesses in Arctic mid-ocean ridge basalts from the Kolbeinsey, Mohns, Knipovich, and Gakkel Ridges 99

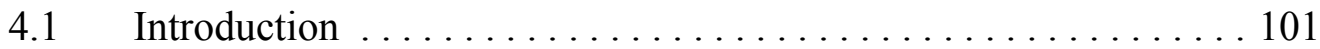

4.1.1 Uranium-Series Isotopes at Slow-Spreading Mid-Ocean

Ridges ............................ 101

4.1.2 Global Observations and the Arctic MOR ............101

$4.2 \quad$ Geologic Setting ............................. 104

$4.3 \quad$ Results .................................. 110

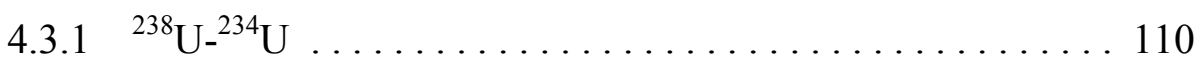

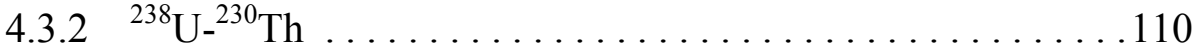

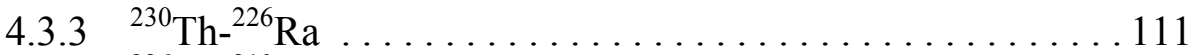

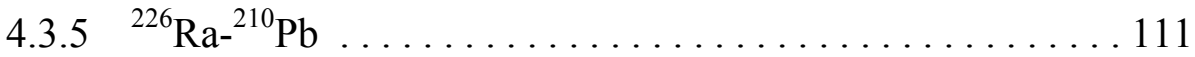

4.3.6 Radiogenic Isotope Analyses . . . . . . . . . . . . . . . . . 114

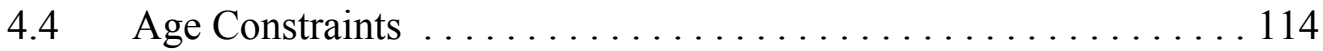

$4.5 \quad$ Arctic Melt Generation . . . . . . . . . . . . . . . . . . 116

4.6 Global MORB Petrogenesis . ..........................119

4.7 Conclusions ............................... 124 


\section{CHAPTER 1:}

\section{BASALT PETROGENESIS BENEATH SLOW- AND ULTRASLOW- SPREADING ARCTIC MID-OCEAN RIDGES: INTRODUCTION}

The presence of uranium-series disequilibria in both mid-ocean ridge basalts (MORB) and ocean island basalts (OIB) has provided new insights into the melt generation and magma transport processes occurring beneath volcanic centers. In the three studies presented here, I attempt to better constrain how mantle rocks melt to produce basaltic magmas, through a series of experimental and analytical approaches.

In Chapter Two, I explore how $\mathrm{U}$ and Th elemental partitioning provides important constraints on melting models, depth of melting, and specifically generation of alkaline OIB. ${ }^{238} \mathrm{U}_{-}{ }^{230} \mathrm{Th}$ disequilibria in particular are sensitive to the presence of garnet (Gt), because experimental determinations of mineral-melt partition coefficients $\left(D_{i}^{\text {Mineral/Melt }}=\mathrm{c}_{i}^{\text {Mineral }} / \mathrm{c}_{i}^{\text {Melt }}\right.$, where $\mathrm{c}_{i}$ is the weight concentration of element $i$ in the mineral or the melt) indicate that $\mathrm{U}$ is more compatible than Th in Gt during partial melting (i.e. $\left.D_{T h}{ }^{G t / M e l t} / D_{U}{ }^{G t / M e l t}<1\right)$. Garnet and clinopyroxene $(\mathrm{Cpx})$ are the principal hosts for $\mathrm{U}$ and $\mathrm{Th}$ in the upper mantle and thus control $\mathrm{U}-\mathrm{Th}$ partitioning behavior, but unlike with Gt, $D_{T h}{ }^{C p x / M e l t} / D_{U}{ }^{C p x / M e l t}$ is typically greater than 1 (e.g. (BEATTIE, 1993a; BeAtTIE, 1993b; HAuri et al., 1994; LA TouretTE and BurnetT, 1992; LA TOURETTE et al., 1993; SALTERS and LONGHI, 1999; SALTERS et al., 2002)). Thus, the presence of ${ }^{230} \mathrm{Th}$ excesses in MORB and OIB is generally taken as an indication of residual Gt in their source regions (e.g. (BOURDON et al., 1996b)).

Most MORB and OIB have $\left({ }^{230} \mathrm{Th} /{ }^{238} \mathrm{U}\right)>1$ (Fig. 1), indicating the presence of Gt (or Cpx with small M2 site radii; (LANDWEHR et al., 2001; WoOD et al., 1999)) in the melt regime (BeAttie, 1993a; BeAttie, 1993b; Bourdon et al., 1996a; Bourdon et al., 1996b; Goldstein et al., 1989; Goldstein et al., 1992; LA TOURETTE and BuRnETt, 1992; LA TOURETTE et al., 1993; LundSTROM, 2000; LunDSTROM, 2003; LuNDSTROM et al., 1998a; Lundstrom et al., 1994; Lundstrom et al., 1998b; PeATE et al., 2001; Sims et al., 2003; Sims et al., 1999; SIMS et al., 1995; SiMS et al., 2002; TEPLEY et al., 2004). 


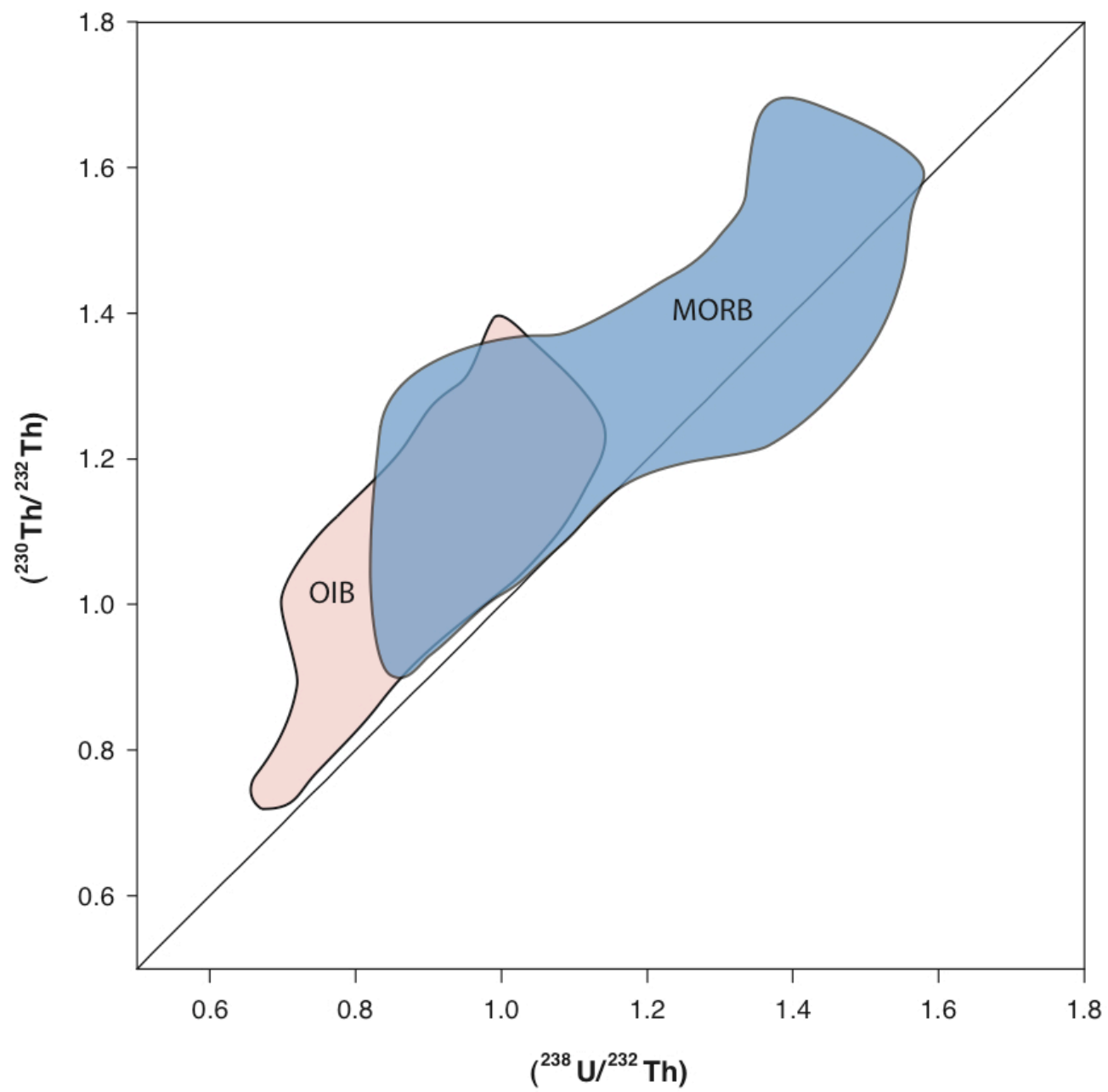

Figure 1. $\left({ }^{238} \mathrm{U} /{ }^{232} \mathrm{Th}\right)$ vs. $\left.{ }^{230} \mathrm{Th} /{ }^{232} \mathrm{Th}\right)$ "equiline" diagram showing global mid-ocean ridge basalt (MORB; blue field (BOURDON et al., 1996a; GolDSTEIN et al., 1989; GOLDSTEIN et al., 1992; GOLDSTEIN et al., 1993; LundSTROM et al., 1999; PEATE et al., 2001; Sims et al., 1995; Sims et al., 2002; StuRM et al., 2000; TEPLEY et al., 2004)) and ocean island basalt (OIB; pink field (BOURDON et al., 1998; ClAUDE-IVANAJ et al., 1998; Claude-IVANAJ et al., 2001; KoKfelt et al., 2003; PietruszKa et al., 2001; PrYTUlaK and ElliotT, 2008; SigmARSSON et al., 1998; SimS et al., 1999; SIMS et al., 1995; SiMS and HART, 2006; SiMS et al., 2008; STRACKE et al., 2003a; STRACKE et al., 2003b; TURNER et al., 1997; WIDOM et al., 1997)) data.

While a number of upper mantle rocks can contain Gt, the stability of Gt in peridotite depends on pressure. Thus if the host of Gt is peridotite, the dominant mantle lithology, measured $\left({ }^{230} \mathrm{Th} /{ }^{238} \mathrm{U}\right)$ in MORB provides a depth control for melting. For this control to be robust the plausibility of melting other mantle lithologies must be ruled out or constrained. To fully evaluate the possibility of melting alternate, Gt-bearing lithologies 
instead of peridotite, I have measured $\mathrm{U}$ and Th partition coefficients in silica-poor garnet pyroxenite, a minor mantle lithology for which such measurements have been lacking. Partial melting of silica-poor garnet pyroxenites may be able to produce alkaline basaltic melts at OIB settings (HirschmanN et al., 2003; Kogiso et al., 2004; PertermanN and HIRSCHMANN, 2003), making it important to fully test the ability of such a rock to produce melts similar to measured OIB geochemical data.

Chapter Two presents experimentally measured partition coefficients for Cpx and Gt compositions appropriate for partial melting of silica-poor garnet pyroxenite at 2.5 $\mathrm{GPa}$, with a focus on partitioning behavior of $\mathrm{U}$ and $\mathrm{Th}$. I use these new experimental results to test the capacity of garnet pyroxenite to generate the $\left({ }^{230} \mathrm{Th} /{ }^{238} \mathrm{U}\right)$ disequilibria observed in alkaline OIB. The relative compatibilities of $U$ and Th in both Gt and Cpx are different in pyroxenites than in other source lithologies: for a given melting rate and extent of partial melting, such mafic lithologies tend to produce larger ${ }^{230} \mathrm{Th}$ excesses than peridotite. The greater overall extents of melting experienced by eclogites and pyroxenites relative to peridotite damp this effect for mixtures of melts, but such binary peridotite-pyroxenite melt mixes are capable of producing the range of ${ }^{230} \mathrm{Th}$ excesses and, for the most part, Sm and $\mathrm{Nd}$ fractionations and $\varepsilon_{\mathrm{Nd}}$ values found in OIB lavas. However, as noted by Stracke et al. (1999), the trends that Hawaiian OIB form in diagrams of $\left({ }^{230} \mathrm{Th} /{ }^{238} \mathrm{U}\right)$ vs. isotopic or trace element ratios have the opposite sense of that expected from progressive melting with pyroxenite in the source, arguing against pyroxenite in the source of Hawaii.

While some variations in U-series systematics may have a lithologic origin, the variations observed in mid-ocean ridge basalts (MORB) also potentially record the effects of different rates of melt production and transport in the upper mantle. Complete geochemical data sets including major element, trace element, long-lived radiogenic isotope, and U-series data are necessary to fully evaluate competing effects of source variations and variations in melting and melt transport processes. To understand geographic variations, a study of a mid-ocean ridge (MOR) segment also benefits from 
detailed geographic coverage. Such a detailed, complete data set currently only exists for $9-10^{\circ} \mathrm{N}$ on the East Pacific Rise (EPR), a fast spreading ridge (SIMS et al., 2002).

To evaluate models for melt generation and better understand MORB geochemical data, in Chapter Three I present a geographically- and geochemically detailed case study of the Kolbeinsey Ridge, the first such study of a slow-spreading ridge. In addition to its slow spreading rate, Kolbeinsey Ridge has a very shallow ridge axis. Kolbeinsey Ridge MORB exhibit large degrees of melting (e.g. low $\mathrm{Na}_{8}$ values) and nearly constant depleted trace element and isotopic compositions. My data help to constrain the extent to which U-series disequilibria in a slow-spreading, shallow ridge location reflect 1) variations in source composition, or 2) variations in the melting process, and to evaluate the differences between these melting processes at varying spreading rates. For this study, I present measurements of U-Th disequilibria in a suite of 33 samples with complete major element, trace element, and $\mathrm{Nd}, \mathrm{Sr}, \mathrm{Pb}$, and $\mathrm{Hf}$ isotopic data. I find that unaltered Kolbeinsey Ridge lavas have universally high $\left({ }^{230} \mathrm{Th} /{ }^{238} \mathrm{U}\right)$, with a narrow range of $\left({ }^{230} \mathrm{Th} /{ }^{232} \mathrm{Th}\right)$ and widely varying $\left({ }^{238} \mathrm{U} /{ }^{232} \mathrm{Th}\right)($ Fig. 2$)$. The relatively uniform long-lived radiogenic isotopes for the ridge argue for a homogeneous mantle source, suggesting that it is produced by variations in the melting process.

These ${ }^{230} \mathrm{Th}_{-}{ }^{238} \mathrm{U}$ disequilibria can be explained by a long, deep peridotitic melting column that extends well into the garnet stability field, producing ${ }^{230} \mathrm{Th}$ excesses and thick crust. Ultra-depleted trace element ratios, however, reflect either a relatively young mantle source, potentially related to the young Arctic ridge system, or recent introduction of depleted source material, possibly from the Iceland plume.

In addition to the focused case study of the Kolbeinsey Ridge, in Chapter Four I examine the slow- to ultraslow-spreading MOR of the Arctic as a broader, regional study, to evaluate models for global MORB production. The Arctic Ridge system extends northward from the Tjörnes Fracture Zone (FZ) at the northern edge of Iceland and comprises the Kolbeinsey Ridge, the Mohns Ridge, the Knipovich Ridge, and the ultraslow Gakkel Ridge. Spreading rates decrease northward from $18 \mathrm{~mm} / \mathrm{yr}$ on the 


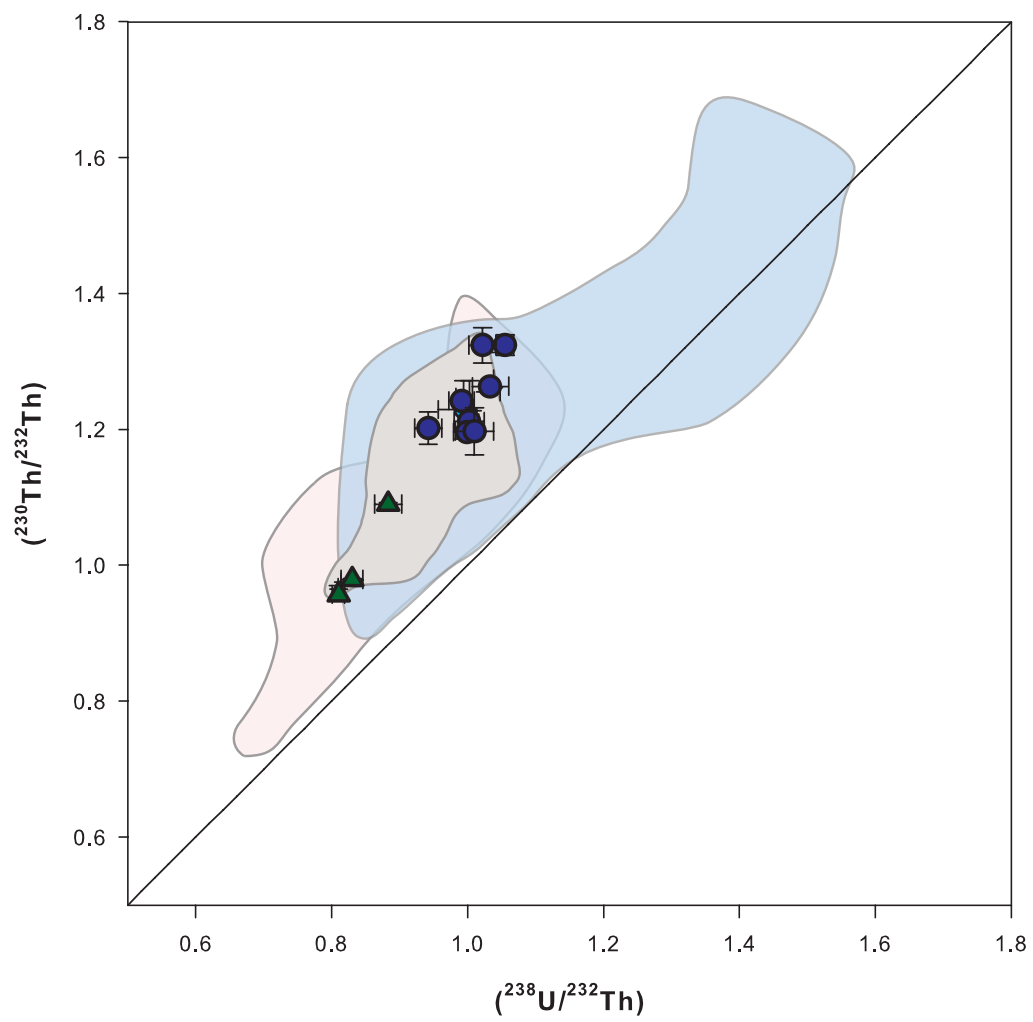

Figure 2. Equiline diagram showing Kolbeinsey Ridge data measured in this study. Fields as in Fig. 1, with Iceland data (KOKFELT et al., 2003; STRACKE et al., 2003a; STRACKE et al., 2003b) removed from the OIB field and shown separately in gray. Blue circles are unaltered samples from the depleted portion of the Kolbeinsey Ridge, and green triangles represent unaltered samples from the isotopically enriched far-north Kolbeinsey Ridge.

Kolbeinsey to $\leq 12 \mathrm{~mm} / \mathrm{yr}$. in the Eastern Volcanic Zone (EVZ) of the Gakkel (Breivik et al., 2006; Mosar et al., 2002), making it the ultraslow global endmember for oceanic spreading. Elevation of the ridge axis and major-element measures of degree of melting also decrease systematically northward. Uranium-series analysis of Arctic lavas thus provides an endmember test for 1) the robustness of the two-porosity melting model for the full range of oceanic spreading rates, 2) the role of mantle heterogeneity, and 3) the relationship between crustal thickness and melt process. In this study I present the results of ${ }^{238} \mathrm{U},{ }^{230} \mathrm{Th},{ }^{226} \mathrm{Ra},{ }^{235} \mathrm{U}$, and ${ }^{210} \mathrm{~Pb}$, as well as $\mathrm{Hf}, \mathrm{Nd}, \mathrm{Sr}$, and $\mathrm{Pb}$ isotopic analyses for a suite of 27 additional samples from the Arctic MOR system, and then I compare the results for Arctic MORB with data from the global ridge system (Fig. 3). 


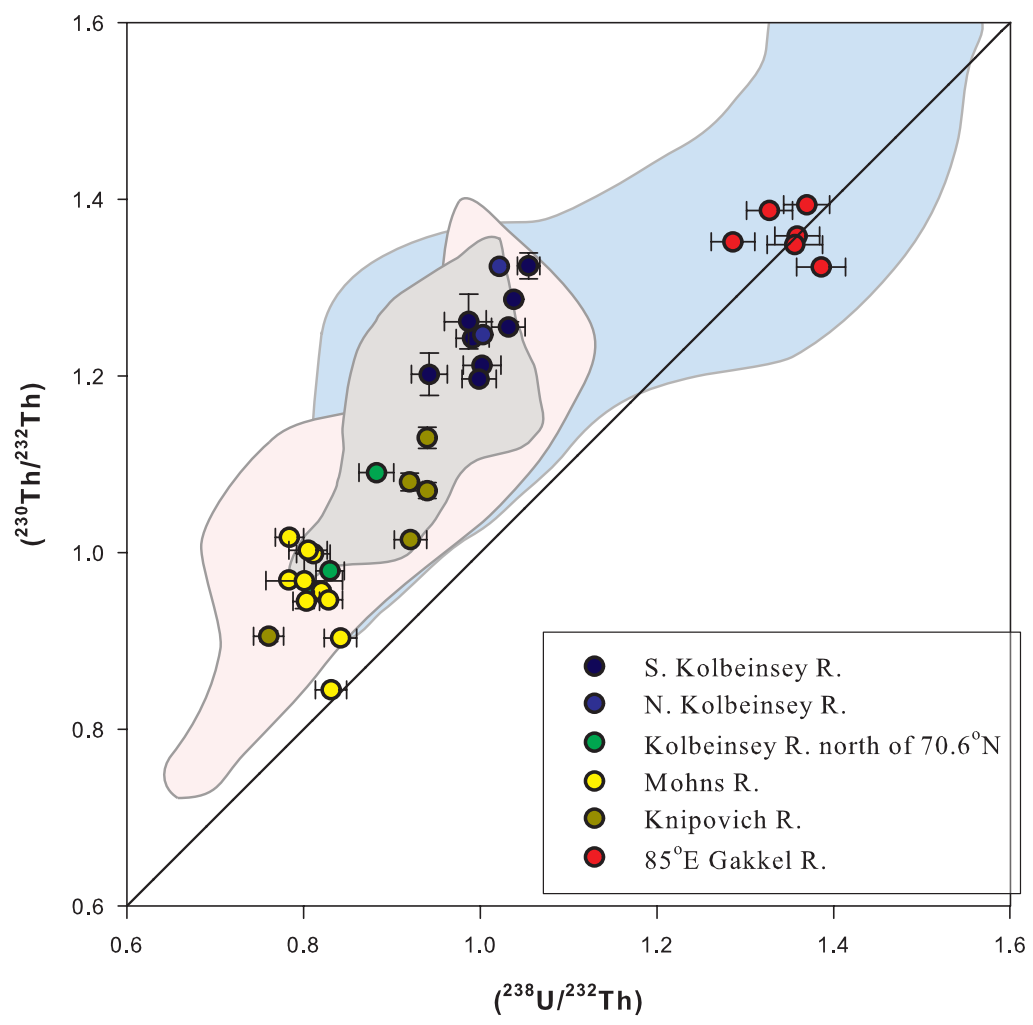

Figure 3. Equiline diagram with fields after Fig. 2, showing all new data for unaltered samples measured and reported in Chapters Three and Four.

While results for the Kolbeinsey Ridge indicated a relatively homogeneous mantle source, evidence from the literature and my analyses suggests a stronger heterogeneous source control over lavas from the more northerly Mohns and Knipovich Ridges. ${ }^{238} \mathrm{U}_{-}^{230} \mathrm{Th}$ results for these two ridges form an array that can be easily explained by a number of models where melts from geochemically distinct mantle sources variably mix prior to eruption. Lavas from $85^{\circ} \mathrm{E}$ on the Gakkel Ridge, on the other hand, are remarkably homogeneous and do not form a sloped array. These MORB do, however, lie at the low $\left({ }^{230} \mathrm{Th} /{ }^{238} \mathrm{U}\right)$, high $\left({ }^{226} \mathrm{Ra} /{ }^{230} \mathrm{Th}\right)$ end of the negative global correlation between $\left({ }^{226} \mathrm{Ra} /{ }^{230} \mathrm{Th}\right)$ and $\left({ }^{230} \mathrm{Th} /{ }^{238} \mathrm{U}\right)$. This correlation provides strong support for models in which MORB are produced by mixing of melts from different depths in the melt column (JULL et al., 2002; KeLEMEN et al., 1997; Sims et al., 1995; Sims et al., 2002). 
These new Kolbeinsey, Mohns, Knipovich, and Gakkel Ridge data corroborate the Bourdon et al. (1996) observation of a negative correlation between average axial ridge depth and average ridge $\left({ }^{230} \mathrm{Th} /{ }^{238} \mathrm{U}\right)$, suggesting a global mantle temperature control. However, unlike mean $\left({ }^{230} \mathrm{Th} /{ }^{238} \mathrm{U}\right)$, the range and variation in ${ }^{238} \mathrm{U}-{ }^{230} \mathrm{Th}$ systematics results from complex factors including mantle chemical heterogeneities, and the rate of upwelling and its effect on melt homogenization.

\section{References}

Beattie, P., 1993a. The Generation of Uranium Series Disequilibria by Partial Melting of Spinel Peridotite - Constraints from Partitioning Studies. Earth Planet Sc Lett 117, 379-391.

Beattie, P., 1993b. Uranium Thorium Disequilibria and Partitioning on Melting of Garnet Peridotite. Nature 363, 63-65.

Bourdon, B., Joron, J. L., Claude-Ivanaj, C., and Allegre, C. J., 1998. U-Th-Pa-Ra systematics for the Grande Comore volcanics: melting processes in an upwelling plume. Earth Planet Sc Lett 164, 119-133.

Bourdon, B., Langmuir, C. H., and Zindler, A., 1996a. Ridge-hotspot interaction along the Mid-Atlantic Ridge between 37 degrees $30^{\prime}$ and 40 degrees 30 'N: The U-Th disequilibrium evidence. Earth Planet Sc Lett 142, 175-189.

Bourdon, B., Zindler, A., Elliott, T., and Langmuir, C. H., 1996b. Constraints on mantle melting at mid-ocean ridges from global U-238-Th-230 disequilibrium data. Nature 384, 231-235.

Breivik, A. J., Mjelde, R., Faleide, J. I., and Murai, Y., 2006. Rates of continental breakup magmatism and seafloor spreading in the Norway Basin-Iceland plume interaction. J Geophys Res-Sol Ea 111, -.

Claude-Ivanaj, C., Bourdon, B., and Allegre, C. J., 1998. Ra-Th-Sr isotope systematics in Grande Comore Island: a case study of plume-lithosphere interaction. Earth Planet Sc Lett 164, 99-117.

Claude-Ivanaj, C., Joron, J. L., and Allegre, C. J., 2001. U-238-Th-230-Ra-226 fractionation in historical lavas from the Azores: long-lived source heterogeneity vs. metasomatism fingerprints. Chem Geol 176, 295-310.

DePaolo, D. J., 1981. Trace-Element and Isotopic Effects of Combined Wallrock Assimilation and Fractional Crystallization. Earth Planet Sc Lett 53, 189-202.

Goldstein, S. J., Murrell, M. T., and Jackecky, D. R., 1989. Th and U isotopic systematics of basalts from the Juan de Fuca and Gorda Ridges by mass spectrometry. Earth Planet Sc Lett 96, 134-146. 
Goldstein, S. J., Murrell, M. T., Janecky, D. R., Delaney, J. R., and Clague, D. A., 1992. Geochronology and Petrogenesis of Morb from the Juan-De-Fuca and Gorda Ridges by U-238 Th-230 Disequilibrium. Earth Planet Sc Lett 109, 255-272.

Goldstein, S. J., Murrell, M. T., and Williams, R. W., 1993. Pa-231 and Th-230 Chronology of Midocean Ridge Basalts. Earth Planet Sc Lett 115, 151-159.

Hauri, E. H., Wagner, T. P., and Grove, T. L., 1994. Experimental and Natural Partitioning of Th, U, $\mathrm{Pb}$ and Other Trace-Elements between Garnet, Clinopyroxene and Basaltic Melts. Chemical Geology 117, 149-166.

Hirschmann, M. M., Kogiso, T., Baker, M. B., and Stolper, E. M., 2003. Alkalic magmas generated by partial melting of garnet pyroxenite. Geology 31, 481-484.

Jull, M., Kelemen, P. B., and Sims, K., 2002. Consequences of diffuse and channelled porous melt migration on uranium series disequilibria. Geochim Cosmochim Ac 66, 4133-4148.

Kelemen, P. B., Hirth, G., Shimizu, N., Spiegelman, M., and Dick, H. J. B., 1997. A review of melt migration processes in the adiabatically upwelling mantle beneath oceanic spreading ridges. Philosophical Transactions of the Royal Society of London Series a-Mathematical Physical and Engineering Sciences 355, 283-318.

Kogiso, T., Hirschmann, M. M., and Pertermann, M., 2004. High-pressure partial melting of mafic lithologies in the mantle. Journal of Petrology 45, 2407-2422.

Kokfelt, T. F., Hoernle, K., and Hauff, F., 2003. Upwelling and melting of the Iceland plume from radial variation of U-238-Th-230 disequilibria in postglacial volcanic rocks. Earth Planet Sc Lett 214, 167-186.

La Tourette, T. Z. and Burnett, D. S., 1992. Experimental determination of U-partitioning and Th-partitioning between cpx and natural and synthetic basaltic liquid. Earth Planet Sc Lett 110, 227-244.

La Tourette, T. Z., Kennedy, A. K., and Wasserburg, G. J., 1993. Thorium-uranium fractionation by garnet: Evidence for a deep source and rapid rise of oceanic basalts. Science 261, 729-742.

Landwehr, D., Blundy, J., Chamorro-Perez, E. M., Hill, E., and Wood, B., 2001. U-series disequilibria generated by partial melting of spinel lherzolite. Earth Planet Sc Lett 188, 329-348.

Lundstrom, C., 2000. Models of U-series disequilibria generation in MORB: the effects of two scales of melt porosity. Phys Earth Planet In 121, 189-204.

Lundstrom, C. C., 2003. Uranium-series disequilibria in mid-ocean ridge basalts: Observations and models of basalt genesis. Rev Mineral Geochem 52, 175-214.

Lundstrom, C. C., Gill, J., Williams, Q., and Hanan, B. B., 1998a. Investigating solid mantle upwelling beneath mid-ocean ridges using U-series disequilibria. II. A local study at 33 degrees Mid-Atlantic Ridge. Earth Planet Sc Lett 157, 167-181.

Lundstrom, C. C., Sampson, D. E., Perfit, M. R., Gill, J., and Williams, Q., 1999. Insights into mid-ocean ridge basalt petrogenesis: U-series disequilibria from the Siqueiros Transform, Lamont Seamounts, and East Pacific Rise. J Geophys Res-Sol Ea 104, 13035-13048.

Lundstrom, C. C., Shaw, H. F., Ryerson, F. J., Phinney, D. L., Gill, J. B., and Williams, Q., 1994. Compositional Controls on the Partitioning of U, Th, Ba, Pb, Sr and $\mathrm{Zr}$ 
between Clinopyroxene and Haplobasaltic Melts - Implications for Uranium

Series Disequilibria in Basalts. Earth Planet Sc Lett 128, 407-423.

Lundstrom, C. C., Williams, Q., and Gill, J. B., 1998b. Investigating solid mantle

upwelling rates beneath mid-ocean ridges using U-series disequilibria, 1: a global approach. Earth Planet Sc Lett 157, 151-165.

Mosar, J., Lewis, G., and Torsvik, T. H., 2002. North Atlantic sea-floor spreading rates: implications for the Tertiary development of inversion structures of the Norwegian-Greenland Sea. J Geol Soc London 159, 503-515.

Peate, D. W., Hawkesworth, C. J., van Calsteren, P. W., Taylor, R. N., and Murton, B. J., 2001. U-238-Th-230 constraints on mantle upwelling and plume-ridge interaction along the Reykjanes Ridge. Earth Planet Sc Lett 187, 259-272.

Pertermann, M. and Hirschmann, M. M., 2003. Anhydrous partial melting experiments on MORB-like eclogite: Phase relations, phase compositions and mineral-melt partitioning of major elements at 2-3 GPa. Journal of Petrology 44, 2173-2201.

Pietruszka, A. J., Rubin, K. H., and Garcia, M. O., 2001. Ra-226-Th-230-U-238 disequilibria of historical Kilauea lavas (1790-1982) and the dynamics of mantle melting within the Hawaiian plume. Earth Planet Sc Lett 186, 15-31.

Prytulak, J. and Elliott, T., 2008. Doubly-distilling eclogite in ocean island basalt sources. Geochim Cosmochim Ac 72, A765-A765.

Salters, V. J. M. and Longhi, J., 1999. Trace element partitioning during the initial stages of melting beneath mid-ocean ridges. Earth Planet Sc Lett 166, 15-30.

Salters, V. J. M., Longhi, J. E., and Bizimis, M., 2002. Near mantle solidus trace element partitioning at pressures up to $3.4 \mathrm{GPa}$. Geochem Geophy Geosy 3, -.

Sigmarsson, O., Carn, S., and Carracedo, J. C., 1998. Systematics of U-series nuclides in primitive lavas from the 1730-36 eruption on Lanzarote, Canary Islands, and implications for the role of garnet pyroxenites during oceanic basalt formations. Earth Planet Sc Lett 162, 137-151.

Sims, K. W. W., Blichert-Toft, J., Fornari, D. J., Perfit, M. R., Goldstein, S. J., Johnson, P., DePaolo, D. J., Hart, S. R., Murrell, P. J., Michael, P. J., Layne, G. D., and Ball, L. A., 2003. Aberrant youth: Chemical and isotopic constraints on the origin of off-axis lavas from the East Pacific Rise, 9 degrees-10 degrees N. Geochem Geophy Geosy 4, -.

Sims, K. W. W., DePaolo, D. J., Murrell, M. T., Baldridge, W. S., Goldstein, S., Clague, D., and Jull, M., 1999. Porosity of the melting zone and variations in the solid mantle upwelling rate beneath Hawaii: Inferences from U-238-Th-230-Ra-226 and U-235-Pa-231 disequilibria. Geochim Cosmochim Ac 63, 4119-4138.

Sims, K. W. W., Depaolo, D. J., Murrell, M. T., Baldridge, W. S., Goldstein, S. J., and Clague, D. A., 1995. Mechanisms of Magma Generation beneath Hawaii and Midocean Ridges - Uranium/Thorium and Samarium/Neodymium Isotopic Evidence. Science 267, 508-512.

Sims, K. W. W., Goldstein, S. J., Blichert-Toft, J., Perfit, M. R., Kelemen, P., Fornari, D. J., Michael, P., Murrell, M. T., Hart, S. R., DePaolo, D. J., Layne, G., Ball, L., Jull, M., and Bender, J., 2002. Chemical and isotopic constraints on the 
generation and transport of magma beneath the East Pacific Rise. Geochim Cosmochim Ac 66, 3481-3504.

Sims, K. W. W. and Hart, S. R., 2006. Comparison of Th, Sr, Nd and Pb isotopes in oceanic basalts: Implications for mantle heterogeneity and magma genesis. Earth Planet Sc Lett 245, 743-761.

Sims, K. W. W., Hart, S. R., Reagan, M. K., Blusztajn, J., Staudigel, H., Sohn, R. A., Layne, G. D., and Ball, L. A., 2008. 238U-Th-230-Ra-226-Pb-210-Po-210, Th232-Ra-228, and U-235-Pa-231 constraints on the ages and petrogenesis of Vailulu'u and Malumalu Lavas, Samoa. Geochem Geophy Geosy 9, -.

Stracke, A., Salters, V. J. M., and Sims, K. W. W., 1999. Assessing the presence of garnet-pyroxenite in the mantle sources of basalts through combined hafniumneodymium-thorium isotope systematics. Geochem Geophy Geosy 1.

Stracke, A., Zindler, A., Salters, V. J. M., McKenzie, D., Blichert-Toft, J., Albarede, F., and Gronvold, K., 2003a. Theistareykir revisited. Geochem Geophy Geosy 4, -.

Stracke, A., Zindler, A., Salters, V. J. M., McKenzie, D., and Gronvold, K., 2003b. The dynamics of melting beneath Theistareykir, northern Iceland. Geochem Geophy Geosy 4, -.

Sturm, M. E., Goldstein, S. J., Klein, E. M., Karson, J. A., and Murrell, M. T., 2000. Uranium-series age constraints on lavas from the axial valley of the Mid-Atlantic Ridge, MARK area. Earth Planet Sc Lett 181, 61-70.

Tepley, F. J., Lundstrom, C. C., Sims, K. W. W., and Hekinian, R., 2004. U-series disequilibria in MORB from the Garrett Transform and implications for mantle melting. Earth Planet Sc Lett 223, 79-97.

Turner, S., Hawkesworth, C., Rogers, N., and King, P., 1997. U-Th isotope disequilibria and ocean island basalt generation in the Azores. Chem Geol 139, 145-164.

Widom, E., Carlson, R. W., Gill, J. B., and Schmincke, H. U., 1997. Th-Sr-Nd-Pb isotope and trace element evidence for the origin of the Sao Miguel, Azores, enriched mantle source. Chem Geol 140, 49-68.

Wood, B. J., Blundy, J. D., and Robinson, J. A. C., 1999. The role of clinopyroxene in generating U-series disequilibrium during mantle melting. Geochim Cosmochim Ac 63, 1613-1620. 


\section{CHAPTER 2:}

\section{PARTITIONING OF U AND TH DURING GARNET PYROXENITE PARTIAL MELTING: CONSTRAINTS ON THE SOURCE OF ALKALINE OCEAN ISLAND BASALTS}

Previously published as "Partitioning of $\mathrm{U}$ and Th during garnet pyroxenite partial melting: Constraints on the source of alkaline ocean island basalts" in 2008 by L.J. Elkins, G.A. Gaetani, and K.W.W. Sims in Earth and Planetary Science Letters, vol. 265, pp. 270-286. Reprinted with permission of Elsevier, (C) 2008 


\title{
Partitioning of $U$ and Th during garnet pyroxenite partial melting: Constraints on the source of alkaline ocean island basalts
}

\author{
L.J. Elkins *, G.A. Gaetani, K.W.W. Sims \\ Woods Hole Oceanographic Institution, Woods Hole, MA 02543, United States
}

Received 27 March 2007; received in revised form 4 October 2007; accepted 12 October 2007

Available online 26 October 2007

Editor: R.W. Carlson

\begin{abstract}
Uranium series disequilibria in ocean island basalts (OIB) provide evidence for the presence of garnet in their source region. It has been suggested that enriched OIB signatures derive from mantle lithologies other than peridotite, such as eclogite or pyroxenite, and, in particular, that silica-poor garnet pyroxenite is the source lithology for alkali basalts. To test the ability of such a source to produce the $\mathrm{U}-\mathrm{Th}$ disequilibria observed in alkali OIB, we determined experimentally clinopyroxene-melt and garnetmelt partition coefficients for a suite of trace elements, including $\mathrm{U}$ and $\mathrm{Th}$, at $2.5 \mathrm{GPa}$ and $1420-1450{ }^{\circ} \mathrm{C}$. The starting composition for the experiments was a $21 \%$ partial melt of a silica-poor garnet pyroxenite. Experimentally determined clinopyroxene-melt partition coefficients range from $0.0083 \pm 0.0006$ to $0.020 \pm 0.002$ for Th and from $0.0094 \pm 0.0006$ to $0.024 \pm$ 0.002 for $\mathrm{U}$, and garnet-melt partition coefficients are $0.0032 \pm 0.0004$ for Th and $0.013 \pm 0.002$ for U. Comparison of our experimental results with partition coefficients from previous experimental studies shows that the relative compatibilities of $U$ and Th in both garnet and clinopyroxene are different for different mineral compositions, leading to varying degrees of U/Th fractionation with changing lithology. For a given melting rate and extent of partial melting, mafic lithologies tend to produce larger ${ }^{230} \mathrm{Th}$ excesses than peridotite. However, this effect is minimized by the greater overall extents of melting experienced by eclogites and pyroxenites relative to peridotite. Results from chromatographic, batch, and fractional melting calculations with binary mixing between partial melts of pyroxenite and peridotite, carried out using our new partitioning data for the pyroxenite component and taking into account variable productivities and different solidus depths for the two lithologies, suggest that OIB are not the product of progressive melting of a source containing a fixed quantity of garnet pyroxenite. Melting a peridotite with enriched signatures, and mixing those melts with melts of a depleted, "normal" peridotite, is an alternative explanation for the trends seen in Hawaiian, Azores and Samoan lavas.
\end{abstract}

(C) 2007 Elsevier B.V. All rights reserved.

Keywords: melting; uranium series; partition coefficients; garnet; clinopyroxene; garnet pyroxenite

* Corresponding author. Tel.: +1 508289 3422; fax: +1 508457 2187.

E-mail addresses: lelkins@whoi.edu (L.J. Elkins), ggaetani@whoi.edu (G.A. Gaetani),ksims@whoi.edu (K.W.W.Sims).

\section{Introduction}

Most mid-ocean ridge basalts (MORB) and ocean island basalts (OIB) are not in secular equilibrium with respect to the uranium decay series isotopes. Observed $\left({ }^{230} \mathrm{Th}\right)$ excesses relative to $\left({ }^{238} \mathrm{U}\right)$ (where parentheses 
denote activity) indicate that Th generally behaves less compatibly during partial melting than U (e.g. (Bourdon et al., 1996). Garnet (Gt) and clinopyroxene (Cpx) are the principal hosts for $\mathrm{U}$ and $\mathrm{Th}$ in upper mantle rocks and, therefore, control the behavior of those elements during partial melting. Experimental determinations of mineralmelt partition coefficients $\left(D_{i}^{\text {Mineral/Melt }}=c_{i}^{\text {Mineral }} / c_{i}^{\text {Melt }}\right.$, where $c_{i}$ is the weight concentration of element $i$ in the mineral or the melt) indicate that $U$ is more compatible than Th in Gt during partial melting (i.e. $D_{\mathrm{Th}}^{\mathrm{Gt}} \mathrm{Melt}^{\mathrm{Git}} D_{\mathrm{U}}^{\mathrm{Gelt}}<1$ ), whereas $D_{\mathrm{Th}}^{\mathrm{Cpx} / \mathrm{Melt}} / D_{\mathrm{U}}^{\mathrm{Cpx} / \text { Melt }}$ is typically greater than 1 (e.g. (La Tourette and Burnett, 1992; Beattie, 1993a,b; La Tourette et al., 1993; Hauri et al., 1994). Thus, the presence of ${ }^{230} \mathrm{Th}$ excesses in MORB and OIB is generally taken as an indication of residual Gt in their source regions (e.g. (Bourdon et al., 1996). Whether that Gt resides in peridotite, pyroxenite, eclogite, or some combination thereof remains a matter of debate (e.g. Hirschmann and Stolper, 1996; Lundstrom et al., 1999; Stracke et al., 1999).

The long-lived radiogenic isotopic compositions of OIB indicate that the upper mantle is characterized by trace element heterogeneity (Zindler and Hart, 1986), suggesting that lithologic heterogeneity is also plausible. Because the relative compatibilities of $U$ and Th during partial melting are sensitive to the major element compositions of the solid phases, a detailed understanding of mineral-melt partitioning of $U$ and $T h$ for a range of mafic and ultramafic lithologies (i.e. eclogite, pyroxenite, and peridotite) is necessary to evaluate the importance of each of those rock types in the melt generation process.

The major element compositions of melts produced by partial fusion of eclogites and pyroxenites at upper mantle conditions have been investigated experimentally in a number of studies, and it has been demonstrated that partial melting of silica-poor garnet pyroxenites can produce alkaline basaltic melts (Hirschmann et al., 2003; Pertermann and Hirschmann, 2003; Kogiso et al., 2004). This supports the suggestion that the melting of less abundant mantle lithologies such as eclogite and pyroxenite may play an important role in generating OIB (Hauri, 1996; Sigmarsson et al., 1998; Lassiter et al., 2000; Kogiso and Hirschmann, 2001; Hauri, 2002; Hirschmann et al., 2003; Kogiso et al., 2003, 2004). Clinopyroxenes and Gt in pyroxenites, eclogites, and peridotites have distinct compositions, however, raising the possibility that there may be systematic differences in the fractionation of $U$ from Th during partial melting of these three lithologies. Partition coefficients for $\mathrm{Cpx}$ and Gt appropriate for peridotite partial melting have been experimentally determined over a wide range of temperature and pressure con- ditions (Salters and Longhi, 1999; Salters et al., 2002). Pertermann and Hirschmann (2002) and Pertermann et al. (2004) also measured $D_{i}^{\text {Mineral/Melt }}$ values appropriate for partial melting of MORB-type eclogites that produce silica-rich melts. However, none of the existing experimental studies have generated the partitioning data needed to test whether silica-poor garnet pyroxenite is a realistic source for alkaline basaltic lavas, as suggested by Kogiso et al. (2004).

In this study, partition coefficients for $\mathrm{Cpx}$ and $\mathrm{Gt}$ compositions appropriate for partial melting of silica-poor garnet pyroxenite were determined experimentally at 2.5 GPa. We focus on the partitioning behavior of $U$ and Th and use our experimental results to test the capacity of garnet pyroxenite to generate the $\left({ }^{230} \mathrm{Th} /{ }^{238} \mathrm{U}\right)$ disequilibria observed in alkaline OIB. We find that the relative compatibilities of U and Th in both Gt and Cpx and, thus, U/Th fractionation during partial melting, are different for different source lithologies. For a given melting rate and extent of partial melting, mafic lithologies tend to produce larger ${ }^{230}$ Th excesses than peridotite. However, this effect is damped by the greater overall extents of melting experienced by eclogites and pyroxenites relative to peridotite. Mixtures of partial melts from peridotite and silicapoor garnet pyroxenite are capable of producing the range of ${ }^{230} \mathrm{Th}$ excesses and, for the most part, $\mathrm{Sm}$ and $\mathrm{Nd}$ fractionations and $\varepsilon_{\mathrm{Nd}}$ values found in OIB lavas. However, a peridotite source with an enriched trace element and isotopic composition could possibly explain the data as well. As noted by Stracke et al. (1999), trends formed by ocean island lavas from Hawaii in diagrams using these variables have the opposite sense of that expected from progressive melting with pyroxenite in the source. This additional constraint argues against pyroxenite in the source of Hawaii.

\section{Experimental and analytical techniques}

\subsection{Starting materials}

To examine the partitioning behavior of incompatible trace elements during partial fusion of silica-poor garnet pyroxenite, we experimentally determined $D_{i}^{\text {Cpx/Melt }}$ and $D_{i}{ }^{\mathrm{Gt} / \mathrm{Melt}}$ values for $21 \%$ partial melting of pyroxenite MIX-1G at $2.5 \mathrm{GPa}$, previously studied by Hirschmann et al. (2003) and Kogiso et al. (2003). This bulk composition was found by Kogiso et al. (2003) to produce alkaline basalts during partial melting at upper mantle conditions. The melt composition from experiment 95MMH15 reported by Hirschmann et al. (2003) (see Table 1 in the Appendix) was synthesized as the starting mix PX21 from a combination of high-purity 
Table 1

Experimental conditions, phase assemblages and phase proportions

\begin{tabular}{llllll}
\hline Experiment & $\begin{array}{l}\mathrm{P} \\
(\mathrm{GPa})\end{array}$ & $\begin{array}{l}\mathrm{T} \\
\left({ }^{\circ} \mathrm{C}\right)\end{array}$ & $\begin{array}{l}\text { Duration } \\
(\mathrm{h})\end{array}$ & $\begin{array}{l}\text { Run } \\
\text { products }\end{array}$ & $\begin{array}{l}\text { Phase proportions } \\
(\text { wt. } \%)\end{array}$ \\
\hline PX21f-4 & 2.5 & 1440 & 120 & $\mathrm{Gl}, \mathrm{Cpx}, \mathrm{Gt}$ & $76.5 \% \mathrm{Gl} ; 14.1 \% \mathrm{Cpx} ; 8.8 \% \mathrm{Gt} ; 0.17$ \\
PX21f-5 & 2.5 & 1450 & 144 & $\mathrm{Gl}, \mathrm{Cpx}$ & $91.4 \% \mathrm{Gl} ; 7.8 \% \mathrm{Cpx} ; 1.24$ \\
PX21f-17 & 2.5 & $1440^{\mathrm{a}}$ & 72 & $\mathrm{Gl}, \mathrm{Cpx}, \mathrm{Sp}$ & $91.7 \% \mathrm{Gl} ; 6.8 \% \mathrm{Cpx} ; 0.2 \% \mathrm{Sp} ; 3.19$ \\
PX21g-2 & 2.5 & 1420 & 48 & $\mathrm{Gl}, \mathrm{Cpx}, \mathrm{Sp}$ & $90.4 \% \mathrm{Gl} ; 7.4 \% \mathrm{Cpx} ; 1.0 \% \mathrm{Sp} ; 1.07$ \\
PX21h-2 & 2.5 & 1420 & 48 & $\mathrm{Gl}, \mathrm{Cpx}, \mathrm{Sp}$ & $86.7 \% \mathrm{Gl} ; 11.2 \% \mathrm{Cpx} ; 1.2 \% \mathrm{Sp} ; 0.76$ \\
\hline
\end{tabular}

${ }^{\text {a }}$ Held at $1340{ }^{\circ} \mathrm{C}$ for $6 \mathrm{~h}$ before ramping up to $1440{ }^{\circ} \mathrm{C}$.

${ }^{\mathrm{b}}$ Calculated phase proportions for major element phase analyses (Table 3). Final value shown is mean sum of squares for mass balance analysis.

oxides and carbonates and homogenized by grinding in an agate mortar and pestle under ethanol for $6 \mathrm{~h}$. The mix was then decarbonated at $850{ }^{\circ} \mathrm{C}$, re-ground under ethanol, glassed for $10 \mathrm{~min}$ at $1200^{\circ} \mathrm{C}$ in air in a vertical gas-mixing furnace using a graphite crucible, and ground to a fine powder. The bulk composition of the starting material was determined by fusing an aliquot in a piston cylinder apparatus at $1400{ }^{\circ} \mathrm{C}$ and $1.0 \mathrm{GPa}$, then analyzing the resulting glass by electron microprobe using the protocol described below (composition of the mixture in Table 1 in the Appendix).

Trace elements were added to three different aliquots of the PX21 starting material to minimize potential isobaric interferences and maximize the ion probe trace element signal in the crystals. The combinations of trace elements used in this study are: (1) $\mathrm{U}$ and Th (mix f); (2) $\mathrm{Li}, \mathrm{Rb}, \mathrm{Nd}, \mathrm{U}, \mathrm{Be}, \mathrm{Sr}, \mathrm{Sm}$, and Th (mix g); (3) B, Y, Hf, $\mathrm{La}, \mathrm{V}, \mathrm{Zr}$, Ta, Lu, Cr, Nb, Ba, and $\mathrm{Pb}$ (mix h). Doping levels were $\sim 1$ wt.\% total trace elements in each batch. Uranium and Th were added using nitric acid standard solutions, and all other elements were added as solid oxide or carbonate powders.

\subsection{Experimental methods}

We conducted experiments using a piston-cylinder apparatus with $1.27 \mathrm{~cm}$-diameter assemblies (Boyd and England, 1960). For each experiment, starting materials were packed into a graphite capsule, which constrains the oxygen fugacity in the charge to be $\sim 1.5 \log$ units more reducing than the fayalite-magnetite-quartz (FMQ) oxygen buffer (Ulmer and Luth, 1991), thereby maintaining a reduced $U$ valence state $\left(\mathrm{U}^{4+}\right.$ versus $\left.\mathrm{U}^{6+}\right)$. The capsule was placed inside an alumina sleeve and centered within a straight-walled graphite furnace using crushable $\mathrm{MgO}$ spacers. The pressure medium was sintered $\mathrm{CaF}_{2}$. The friction correction for the assemblies was calibrated against the $\mathrm{Ca}$-Tschermakite breakdown reaction at 1.2 to $1.4 \mathrm{GPa}$ and $1300^{\circ} \mathrm{C}$ (Hays, 1966) and determined to be less than the pressure uncertainty $( \pm 50 \mathrm{MPa})$, so that no correction has been applied to the pressures reported in Table 1. Experiments were conducted using the cold piston-in technique (Johannes et al., 1971) and brought to the desired temperature at a rate of $1{ }^{\circ} \mathrm{C} / \mathrm{s}$. Temperatures were measured and controlled using $\mathrm{W}_{97} \mathrm{Re}_{3}-\mathrm{W}_{75} \mathrm{Re}_{25}$ thermocouples positioned above the sample capsule, with no correction for the effect of pressure on thermocouple EMF. The temperature difference between the position of the thermocouple bead and the center of the sample, determined using offset thermocouples, was $9{ }^{\circ} \mathrm{C}$. We have corrected the temperatures reported in Table 1 for this difference. Temperatures measured by this method are thought to be accurate to within $\pm 10^{\circ} \mathrm{C}$, and pressure is thought to be accurate to within $\pm 0.5 \mathrm{GPa}$. Run durations ranged from 48 to $144 \mathrm{~h}$, and experiments were quenched upon completion by shutting off the power.

\subsection{Analytical methods}

Experimental run products were longitudinally sectioned, mounted in epoxy, polished, and analyzed for major elements using the 5-spectrometer JEOL 733 electron microprobe at Massachusetts Institute of Technology. We used a $10 \mathrm{nA}$ beam current and $15 \mathrm{kV}$ accelerating potential for all analyses. Beam diameters of $10 \mu \mathrm{m}$ and $1 \mu \mathrm{m}$ were used for analyses of glass and crystalline phases, respectively. We measured elements in the glass using count times of $5 \mathrm{~s}$ for $\mathrm{Na}$, $10 \mathrm{~s}$ for $\mathrm{Mn}$ and $\mathrm{Fe}$ and $40 \mathrm{~s}$ for $\mathrm{Mg}, \mathrm{Al}, \mathrm{Si}, \mathrm{Ti}, \mathrm{K}$, and $\mathrm{Ca}$. Peak counting times for pyroxene crystals were $15 \mathrm{~s}$ for $\mathrm{Na}$ and $40 \mathrm{~s}$ for $\mathrm{Mn}$ and $\mathrm{Fe}$, and for $\mathrm{Gt}$ analyses were carried out by counting $\mathrm{Na}$ and $\mathrm{Ti}$ for $20 \mathrm{~s}$ and $\mathrm{Mn}$ and $\mathrm{Fe}$ for $40 \mathrm{~s}$. Data were reduced using a modified ZAF procedure (Armstrong, 1988).

Trace element concentrations were measured by secondary ion mass spectrometry (SIMS) with the Cameca $3 \mathrm{f}$ ion microprobe at Woods Hole Oceanographic Institution. A $\sim 0.1 \mathrm{nA}$ primary $\mathrm{O}^{-}$beam less than $5 \mu \mathrm{m}$ in diameter was used for all analyses due to small Cpx grain sizes. A primary accelerating voltage of 
$8.2 \mathrm{keV}$ with a secondary accelerating voltage of $4.41 \mathrm{keV}$ produced a primary $\mathrm{O}^{-}$beam impact energy of $12.61 \mathrm{keV}$. Following a 3-5 min. pre-burn to remove the Au coat, a single spot was occupied while measuring secondary ion intensities for ${ }^{7} \mathrm{Li},{ }^{9} \mathrm{Be},{ }^{11} \mathrm{~B},{ }^{51} \mathrm{~V},{ }^{52} \mathrm{Cr}$, ${ }^{85} \mathrm{Rb},{ }^{88} \mathrm{Sr},{ }^{89} \mathrm{Y},{ }^{90} \mathrm{Zr},{ }^{93} \mathrm{Nb},{ }^{138} \mathrm{Ba},{ }^{139} \mathrm{La},{ }^{146} \mathrm{Nd},{ }^{147} \mathrm{Sm}$, ${ }^{175} \mathrm{Lu},{ }^{178} \mathrm{Hf},{ }^{181} \mathrm{Ta},{ }^{208} \mathrm{~Pb},{ }^{232} \mathrm{Th}$, or ${ }^{238} \mathrm{U}$ within a $20 \mathrm{eV}$ window centered on a $90 \mathrm{eV}$ offset from the peak of the energy distribution. Count times of $20 \mathrm{~s}$ were used for all elements in experiments PX21g-2 and -h-2, except $\mathrm{Hf}, \mathrm{Ta}$, and $\mathrm{Pb}$, which were measured for $30 \mathrm{~s}$ each. In experiments PX21f-4, -5 , and $-17, \mathrm{U}$ and Th were measured with count times of $30 \mathrm{~s}$. Trace element measurements were normalized to either ${ }^{28} \mathrm{Si}$ or ${ }^{30} \mathrm{Si}$ and calibrated against standards NIST-610 and NIST-612.

\section{Experimental results}

\subsection{Partitioning experiments}

Five experiments were carried out to determine partition coefficients for incompatible trace elements among
Cpx, Gt, and nepheline-normative silicate melt during garnet pyroxenite partial melting at $2.5 \mathrm{GPa}$ and $1420^{\circ}$ to $1450{ }^{\circ} \mathrm{C}$ (Table 1). All experiments produced Cpx, spinel $(\mathrm{Sp})$ and silicate melt. One of the experiments contains a mineral assemblage of $\mathrm{Cpx}+\mathrm{Gt}+\mathrm{Sp}$, while the others contain $\mathrm{Cpx}+\mathrm{Sp}$ only. The absence of $\mathrm{Gt}$ from all but one of the experiments, which were carried out using a single starting mix, is thought to be attributable to sluggish nucleation. All experiments contain large areas of homogeneous, quench growth-free glass.

The experiment conducted at $1450{ }^{\circ} \mathrm{C}$ (just below the liquidus temperature of $1455{ }^{\circ} \mathrm{C}$ inferred from experiment 95MMH15 of Hirschmann et al. (2003)) for $144 \mathrm{~h}$ contains 91 wt.\% silicate melt, 9 wt.\% Cpx $(\sim 20 \mu \mathrm{m})$, and a trace amount of $\mathrm{Sp}$. An experiment held at $1440{ }^{\circ} \mathrm{C}$ for $120 \mathrm{~h}$ produced $77 \mathrm{wt} . \%$ silicate melt, 16 wt.\% Cpx $(\sim 20-30 \mu \mathrm{m}), 6$ wt.\% Gt (up to $\sim 300 \mu \mathrm{m}$ ), many of which poikilitically enclose small pyroxene grains, and trace amounts of $\mathrm{Sp}$. A second experiment conducted at $1440{ }^{\circ} \mathrm{C}$ was initially held at $1340{ }^{\circ} \mathrm{C}$ for $6 \mathrm{~h}$, and then ramped up to $1440{ }^{\circ} \mathrm{C}$ at $1{ }^{\circ} \mathrm{C} / \mathrm{s}$ to approach the same equilibrium from a different

Table 2

Electron microprobe analyses of experimental run products

\begin{tabular}{|c|c|c|c|c|c|c|c|c|c|c|c|c|c|}
\hline Phase & $n$ & $\mathrm{SiO}_{2}$ & $\mathrm{TiO}_{2}$ & $\mathrm{Al}_{2} \mathrm{O}_{3}$ & $\mathrm{Cr}_{2} \mathrm{O}_{3}$ & $\mathrm{FeO}$ & $\mathrm{MnO}$ & $\mathrm{MgO}$ & $\mathrm{CaO}$ & $\mathrm{Na}_{2} \mathrm{O}$ & $\mathrm{K}_{2} \mathrm{O}$ & $\mathrm{P}_{2} \mathrm{O}_{5}$ & Total \\
\hline \multicolumn{14}{|c|}{ Hirschmann et al. (2003) } \\
\hline G1 & 5 & $43.1(7)^{\mathrm{a}}$ & $2.58(9)$ & $14.20(2)$ & - & $13.6(4)$ & $0.15(3)$ & $12.5(3)$ & $10.2(1)$ & $3.72(7)$ & $0.08(2)$ & $0.06(1)$ & 100.2 \\
\hline $\mathrm{Cpx}$ & 10 & $50.8(7)$ & $0.51(2)$ & $10.5(3)$ & - & $5.4(1)$ & $0.10(5)$ & $16.7(1)$ & $14.70(4)$ & $1.2(1)$ & $0.01(1)$ & $0.00(1)$ & 99.9 \\
\hline Gt & 7 & $41.4(2)$ & $0.52(6)$ & $23.0(2)$ & - & $8.2(1)$ & $0.20(4)$ & 19.1(1) & $6.0(1)$ & $0.02(2)$ & $0.01(1)$ & $0.02(3)$ & 98.7 \\
\hline \multicolumn{14}{|c|}{$P X 21 f-4-1440^{\circ} \mathrm{C}-120 \mathrm{~h}$} \\
\hline G1 & 9 & $41.9(2)$ & $3.0(1)$ & $13.8(1)$ & $0.004(12)$ & $15.0(2)$ & $0.13(4)$ & $11.2(2)$ & $9.4(1)$ & $4.7(3)$ & $0.108(9)$ & $0.03(3)$ & 99.3 \\
\hline Cpx & 20 & $49.5(3)$ & $0.57(6)$ & $11.6(2)$ & $0.002(5)$ & $6.6(3)$ & $0.12(2)$ & $15.6(3)$ & $14.6(4)$ & $1.96(6)$ & - & - & 100.5 \\
\hline $\mathrm{Gt}$ & 18 & $41.1(2)$ & $0.55(3)$ & $24.2(2)$ & $0.03(2)$ & $10.8(1)$ & $0.22(4)$ & $16.6(2)$ & $5.7(1)$ & $0.02(2)$ & - & - & 99.1 \\
\hline \multicolumn{14}{|c|}{$P X 21 f-5-1450^{\circ} \mathrm{C}-144 \mathrm{~h}$} \\
\hline Gl & 10 & $42.3(3)$ & $2.7(2)$ & $14.71(7)$ & $0.01(2)$ & $13.7(3)$ & $0.17(5)$ & $11.3(2)$ & $9.48(6)$ & $4.2(2)$ & $0.1(1)$ & $0.05(5)$ & 98.8 \\
\hline $\mathrm{Cpx}$ & 16 & $50.0(5)$ & $0.48(4)$ & $11.6(4)$ & $0.02(1)$ & $6.0(2)$ & $0.11(2)$ & $15.8(3)$ & $14.8(5)$ & $1.66(6)$ & - & - & 100.5 \\
\hline \multicolumn{14}{|c|}{$P X 21 f-17-1440^{\circ} \mathrm{C}-72 \mathrm{~h}$} \\
\hline Gl & 22 & $43.0(2)$ & $2.7(1)$ & $15.1(1)$ & $0.01(2)$ & $13.5(2)$ & $0.17(5)$ & $10.9(1)$ & $9.75(6)$ & $3.8(2)$ & $0.11(1)$ & $0.02(4)$ & 99.2 \\
\hline Cpx & 5 & $49.8(3)$ & $0.53(6)$ & $11.8(4)$ & $0.02(2)$ & $5.8(2)$ & $0.12(2)$ & $15.3(5)$ & $15.5(3)$ & $1.69(7)$ & - & - & 100.6 \\
\hline $\mathrm{Sp}$ & 8 & $1.2(1.1)$ & $0.29(9)$ & $65.5(1.4)$ & $0.01(2)$ & $12.5(3)$ & $0.06(2)$ & 20.1(3) & $0.3(3)$ & - & - & - & 100 \\
\hline \multicolumn{14}{|c|}{$\mathrm{PX} 21 \mathrm{~g}-2-1420^{\circ} \mathrm{C}-48 \mathrm{~h}$} \\
\hline Gl & 24 & $43.6(5)$ & $2.7(1)$ & $14.6(1)$ & $0.04(4)$ & $13.9(3)$ & $0.19(4)$ & $11.8(3)$ & $9.30(7)$ & $4.0(2)$ & $0.11(1)$ & $0.02(3)$ & 100.2 \\
\hline Cpx & 17 & $51.3(7)$ & $0.43(8)$ & $9.9(1.0)$ & $0.00002(7)$ & $6.5(4)$ & $0.13(3)$ & $17.9(1.1)$ & $12.9(9)$ & $1.6(1)$ & - & - & 100.7 \\
\hline $\mathrm{Sp}$ & 12 & $1.0(2.0)$ & $0.26(3)$ & $65.5(2.5)$ & $0.002(4)$ & $12.2(3)$ & $0.09(2)$ & $20.3(2)$ & $0.2(5)$ & - & - & - & 99.6 \\
\hline \multicolumn{14}{|c|}{$P X 21 h-2-1420^{\circ} \mathrm{C}-48 \mathrm{~h}$} \\
\hline Gl & 18 & $43.4(2)$ & $2.8(1)$ & $14.7(1)$ & $0.02(2)$ & $14.3(3)$ & $0.18(5)$ & $11.5(3)$ & $9.51(6)$ & $4.2(2)$ & $0.111(9)$ & $0.006(12)$ & 100.7 \\
\hline $\mathrm{Cpx}$ & 9 & $50.7(6)$ & $0.44(4)$ & $10.2(9)$ & 0 & $6.5(2)$ & $0.12(2)$ & $17.0(1.3)$ & $13.6(1.0)$ & $1.6(2)$ & - & - & 100.3 \\
\hline $\mathrm{Sp}$ & 15 & $0.32(2)$ & $0.26(2)$ & $64.8(4)$ & 0 & $12.6(2)$ & $0.06(3)$ & $19.7(2)$ & $0.008(5)$ & - & - & - & 97.9 \\
\hline
\end{tabular}

${ }^{\text {a }}$ Numbers in parentheses represent $1 \sigma$ standard deviation in terms of least units cited on the basis of replicate analyses. Thus 43.1(7) should be read as $43.1 \pm 0.7$ 
starting condition. This experiment produced 93 wt.\% silicate melt, 7 wt.\% Cpx $(\sim 20 \mu \mathrm{m})$, and a trace amount of $\operatorname{Sp}(\sim 10 \mu \mathrm{m})$.

Additional experiments were conducted at $2.5 \mathrm{GPa}$ and $1420{ }^{\circ} \mathrm{C}$ using starting compositions doped with a larger suite of trace elements (mixes $g$ and $h$ ). The experiment doped with $\mathrm{Li}, \mathrm{Be}, \mathrm{Rb}, \mathrm{Sr}, \mathrm{Nd}, \mathrm{Sm}, \mathrm{Th}$, and $\mathrm{U}$ contains 92 wt.\% melt, 7 wt.\% Cpx ( 200-300 $\mu \mathrm{m})$, and 1 wt. $\%$ Sp $(\sim 100-200 \mu \mathrm{m})$. Similarly, the experiment doped with B, V, Cr, Y, Zr, Nb, Ba, La, Lu, Hf, Ta, and $\mathrm{Pb}$ contains 87 wt.\% silicate melt, 11 wt.\% Cpx $(\sim 500 \mu \mathrm{m})$, and $1 \mathrm{wt} . \% \mathrm{Sp}(\sim 200 \mu \mathrm{m})$.

Major element compositions of silicate melts, Cpx, $\mathrm{Gt}$, and $\mathrm{Sp}$ are reported in Table 2. Clinopyroxene, Gt, and melt compositions are similar to those reported from the pyroxenite partial melting experiments of Hirschmann et al. (2003). The silicate melts produced in our experiments are $\mathrm{SiO}_{2}$-poor ( $41.9 \pm 0.2$ to $43.6 \pm 0.5$ wt. $\%$ ) with 9.5 to $15.8 \mathrm{wt} . \%$ nepheline in their CIPW norms and molar $\mathrm{Mg} /(\mathrm{Mg}+\Sigma \mathrm{Fe})(\mathrm{Mg} \#)$ ranging from 0.57 to 0.60 . Clinopyroxenes have moderately high $\mathrm{Al}_{2} \mathrm{O}_{3}$ and $\mathrm{Na}_{2} \mathrm{O}$ contents $(\sim 11.0$ wt.\% and $\sim 1.7$ wt. $\%$, respectively) resulting in a significant jadeite component. The principal difference between the $\mathrm{Cpx}$ in our experiments and those from Hirschmann et al. (2003) is that ours have lower $\mathrm{Mg} \#$ (a mean of $0.822 \pm 0.006$ for the 5 experiments reported in Table 2, versus $0.846 \pm 0.001$ in Hirschmann et al. (2003)), likely a result of the systematically lower temperatures at which our experiments were carried out.

Compared against experiments on $\mathrm{U}$ and $\mathrm{Th}$ partitioning during partial melting of eclogite, the $\mathrm{Cpx}$ from our experiments are characterized by lower $\mathrm{TiO}_{2}$ $(\sim 0.50$ versus $\sim 3$ wt. $\%), \mathrm{Al}_{2} \mathrm{O}_{3}(\sim 11$ versus $\sim 17$ wt. $\%)$, and $\mathrm{Na}_{2} \mathrm{O}(\sim 2$ versus $\sim 4$ wt.\%), and higher $\mathrm{Mg \#}$ ( $\sim 0.82$ versus $\sim 0.66)$ (Pertermann and Hirschmann, 2002, 2003; Pertermann et al., 2004). The Cpx in our experiments have relatively higher $\mathrm{Al}_{2} \mathrm{O}_{3}(\sim 11$ versus $\sim 8$ wt. $\%), \mathrm{CaO}(\sim 14$ versus $\sim 10$ wt. $\%)$, and $\mathrm{Na}_{2} \mathrm{O}(\sim 2$ versus $\sim 1$ wt. $\%)$ and slightly lower $\mathrm{Mg \#}(\sim 0.82$ versus $\sim 0.88$ ) than experiments looking at $\mathrm{U}$ and $\mathrm{Th}$ partitioning during peridotite partial melting (Salters and Longhi, 1999; Salters et al., 2002; McDade et al., 2003). Finally, compared with $U$ and Th partitioning experiments conducted on near-liquidus basalts, the $\mathrm{Cpx}$ from our experiments have higher $\mathrm{Al}_{2} \mathrm{O}_{3}(\sim 11$ versus $\sim 7$ wt. $\%)$ and $\mathrm{Na}_{2} \mathrm{O}(\sim 2$ versus $\sim 1$ wt. $\%)$, lower $\mathrm{CaO}$ $(\sim 14$ versus $\sim 18$ wt. $\%)$, and slightly lower $\mathrm{Mg \#}$ $(\sim 0.82$ versus $\sim 0.88$; La Tourette and Burnett, 1992 ; Beattie, 1993a,b; Hauri et al., 1994; Wood et al., 1999).

Garnet compositions in our experiments, likewise, are similar to those from the melting experiments of Hirschmann et al. (2003), although with slightly higher $\mathrm{Al}_{2} \mathrm{O}_{3}(24.2 \pm 0.2$ versus $23.0 \pm 0.2)$ and slightly lower $\mathrm{CaO}$ $(5.7 \pm 0.1$ versus $6.0 \pm 0.1$ wt. $\%)$ and $\mathrm{Mg} \#(0.734 \pm 0.001$

Table 3

Experimentally determined mineral-melt partition coefficients

\begin{tabular}{|c|c|c|c|c|c|c|c|c|c|}
\hline & PX21f-4 & & PX21f-5 & PX21f-17 & & PX21g-2 & & PX21h-2 & \\
\hline & $1440^{\circ} \mathrm{C}$, & & $1450{ }^{\circ} \mathrm{C}, 144 \mathrm{~h}$ & $1440^{\circ} \mathrm{C}$, & & $1420^{\circ} \mathrm{C}$, & & $1420^{\circ} \mathrm{C}, 4$ & \\
\hline & Cpx & Gt & Cpx & Cpx & $\mathrm{Sp}$ & Cpx & $\mathrm{Sp}$ & Cpx & $\mathrm{Sp}$ \\
\hline $\mathrm{Li}$ & - & - & - & - & - & $0.22(4)^{\mathrm{a}}$ & 0.13 & - & - \\
\hline $\mathrm{Be}$ & - & - & - & - & - & $0.024(3)$ & 0.10 & - & - \\
\hline B & - & - & - & - & - & - & - & $0.19(9)$ & 0.10 \\
\hline V & - & - & - & - & - & - & - & $1.1(2)$ & 1.3 \\
\hline $\mathrm{Cr}$ & - & - & - & - & - & - & - & $2.8(5)$ & $3.43(8)$ \\
\hline $\mathrm{Rb}$ & - & - & - & - & - & $0.015(2)$ & 0.029 & - & - \\
\hline $\mathrm{Sr}$ & - & - & - & - & - & $0.067(3)$ & 0.0047 & - & - \\
\hline $\mathrm{Y}$ & - & - & - & - & - & - & - & $0.37(6)$ & $0.002(1)$ \\
\hline $\mathrm{Zr}$ & - & - & - & - & - & - & - & $0.09(1)$ & $0.0081(9)$ \\
\hline $\mathrm{Nb}$ & - & - & - & - & - & - & - & $0.0029(8)$ & $0.0006(2)$ \\
\hline $\mathrm{Ba}$ & - & - & - & - & - & - & - & $0.005(2)$ & $0.0006(4)$ \\
\hline $\mathrm{La}$ & - & - & - & - & - & - & - & $0.034(6)$ & $0.0002(1)$ \\
\hline $\mathrm{Nd}$ & - & - & - & - & - & $0.24(1)$ & 0.24 & - & - \\
\hline $\mathrm{Sm}$ & - & - & - & - & - & $0.31(2)$ & 0.18 & - & - \\
\hline $\mathrm{Lu}$ & - & - & - & - & - & - & - & $0.38(6)$ & $0.0007(4)$ \\
\hline $\mathrm{Hf}$ & - & - & - & - & - & - & - & $0.13(3)$ & $0.003(2)$ \\
\hline $\mathrm{Ta}$ & - & - & - & - & - & - & - & $0.008(2)$ & $0.0004(1)$ \\
\hline $\mathrm{Pb}$ & - & - & - & - & - & - & - & $0.2(1)$ & $0.0005(2)$ \\
\hline Th & $0.015(2)$ & $0.0032(4)$ & $0.0083(6)$ & $0.015(1)$ & $0.010(3)$ & $0.020(2)$ & 0.016 & - & - \\
\hline U & $0.017(2)$ & $0.013(2)$ & $0.0094(6)$ & $0.016(1)$ & $0.014(5)$ & $0.024(2)$ & 0.046 & - & - \\
\hline
\end{tabular}

${ }^{\text {a }}$ Numbers in parentheses indicate one standard error uncertainties in terms of least units cited. 
versus $0.806 \pm 0.001)$. Compared with existing eclogite melting and $\mathrm{U}$ and Th partitioning experiments, the Gt from our experiments have relatively low $\mathrm{TiO}_{2}(0.55 \pm 0.03$ versus $\sim 1$ wt. $\%)$ and $\mathrm{CaO}(5.7 \pm 0.1$ versus $\sim 8$ wt. $\%)$, and high $\mathrm{Al}_{2} \mathrm{O}_{3}(24.2 \pm 0.2$ versus $\sim 23$ wt. $\%)$ and $\mathrm{Mg \#}$ $(0.734 \pm 0.001$ versus $\sim 0.61$; Pertermann et al., 2004). Our Gt crystals have higher $\mathrm{Al}_{2} \mathrm{O}_{3}(24.2 \pm 0.2$ versus $\sim 23$ wt. $\%)$ and $\mathrm{CaO}(5.7 \pm 0.1$ versus $\sim 4$ wt. $\%)$ and lower $\mathrm{Mg \#}(0.734 \pm 0.001$ versus $\sim 0.88$; Salters and Longhi, 1999; Salters et al., 2002) than Gt from peridotite melting experiments. Uranium and Th partitioning experiments conducted on near-liquidus basalts have Gt with higher $\mathrm{Al}_{2} \mathrm{O}_{3}(\sim 26$ versus $24.2 \pm 0.2$ wt.\%) and slightly higher $\mathrm{Mg \#}(\sim 0.76$ versus $0.734 \pm 0.001)$ than ours (Beattie, 1993a,b; La Tourette et al., 1993; Hauri et al., 1994).

The partition coefficients determined in this study are reported in Table 3. In Fig. 1, we show how Cpx-melt partition coefficients for $\mathrm{U}$ increase monotonically from $0.0094 \pm 0.0006$ at $1450{ }^{\circ} \mathrm{C}$ to $0.024 \pm 0.002$ at $1420{ }^{\circ} \mathrm{C}$, while $D_{\mathrm{Th}}^{\mathrm{Cpx} / \text { Melt }}$ increases from $0.0083 \pm 0.0006$ to $0.020 \pm 0.002$ over the same temperature range. The $D_{\mathrm{Th}}^{\mathrm{Cpx} / \text { Melt }} / D_{\mathrm{U}}^{\mathrm{Cpx} / \text { Melt }}$ ratios in our experiments are slightly less than 1 , and, with a mean value of $0.88 \pm$ 0.05 , do not vary significantly with temperature. The $D_{\mathrm{Th}}^{\mathrm{Gt} / \mathrm{Melt}}$ value determined from our experiment at $1440{ }^{\circ} \mathrm{C}$ is $0.0032 \pm 0.0004$, nearly a factor of 5 smaller than $D_{\mathrm{Th}}^{\mathrm{Cpx} / \text { Melt }}(0.015 \pm 0.002)$ at the same conditions, whereas $D_{\mathrm{U}}^{\mathrm{Gt} / \text { Melt }}(0.013 \pm 0.002)$ is only slightly smaller than $D_{\mathrm{U}}^{\text {Cpx/Melt }}(0.017 \pm 0.002)$. Our experiments therefore show that $D_{\mathrm{Th}}^{\mathrm{Gt} / \mathrm{Melt}} / D_{\mathrm{U}}^{\mathrm{Gt} / \mathrm{Mel} t}$ $(0.25 \pm 0.04)$ is much smaller than $D_{\mathrm{Th}}^{\mathrm{Cpx} / \text { Melt }} / D_{\mathrm{U}}^{\mathrm{Cpx} / \text { Melt }}$ during garnet pyroxenite partial melting, confirming that Gt is much more effective at producing ${ }^{230} \mathrm{Th}$ excesses.

Clinopyroxene-melt partition coefficients determined at $2.5 \mathrm{GPa}$ and $1420^{\circ} \mathrm{C}$ are presented in Fig. 2, in order of compatibility during peridotite partial melting (Hofmann, 1988), together with partitioning data for partial melting of both eclogites (Pertermann and Hirschmann, 2002; Pertermann et al., 2004) and peridotites (Salters and Longhi, 1999) for comparison. Our $D_{i}{ }^{\mathrm{Cpx} / \mathrm{Melt}}$ values are overall similar to those measured in previous studies, suggesting that the variations in $\mathrm{Cpx}$ composition discussed above do not produce significant changes in compatibility for most trace elements, though $D_{\mathrm{U}}^{\mathrm{Cpx} / \text { Melt }}$ and $D_{\mathrm{Th}}^{\mathrm{Cpx} / \text { Melt }}$, which are lower in eclogites, represent an exception to this.

\subsection{Approach to equilibrium}

The approach to equilibrium for experimental results in this study was evaluated by carrying out experiments
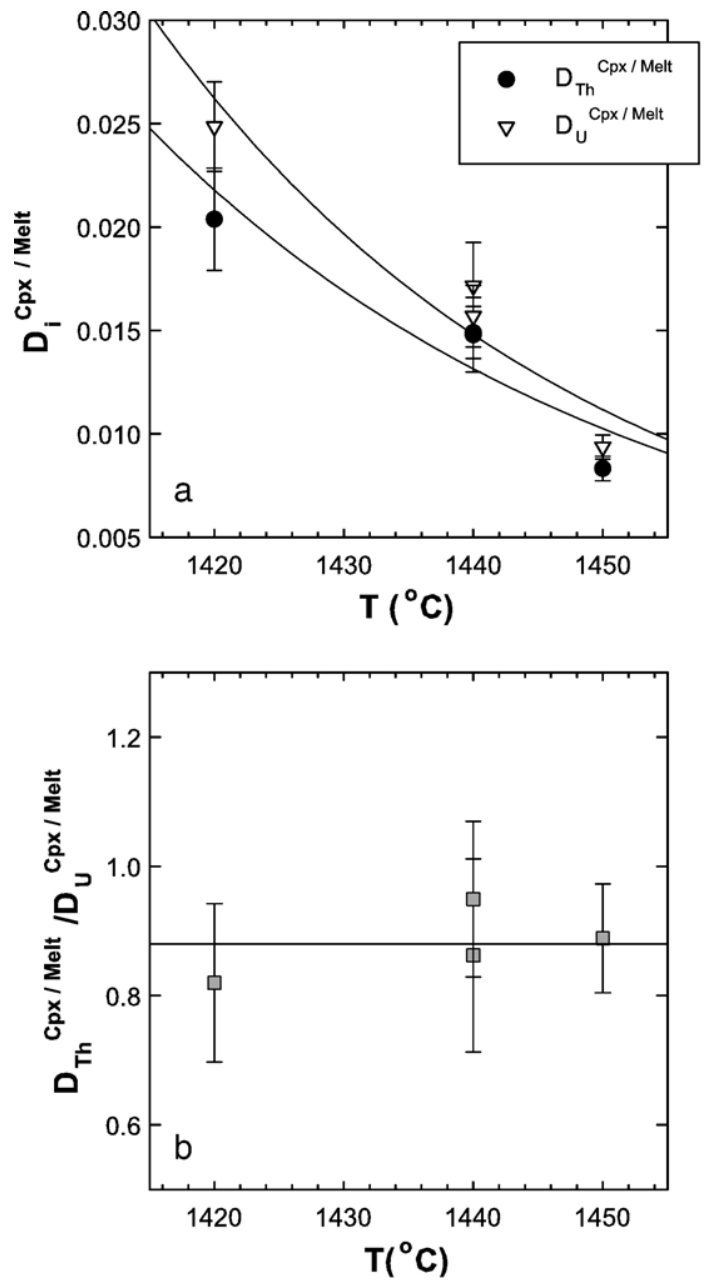

Fig. 1. Temperature vs. (a) $D_{i}^{\mathrm{Cpx} / \mathrm{Melt}}$ and (b) $D_{\mathrm{Th}}^{\mathrm{Cpx} / \mathrm{Melt}} / D_{\mathrm{U}}^{\mathrm{Cpx} / \mathrm{Melt}}$ ratio diagrams, showing measured values from experiments PX21f-4, PX21f-5, PX21f-17, and PX21g-2. Plotted lines show (a) Arrhenius relationships between temperature and partition coefficients and (b) the mean $D_{\mathrm{Th}}^{\mathrm{Cpx} / \text { Melt }} / D_{\mathrm{U}}^{\mathrm{Cpx} / \text { Melt }}$ value, demonstrating that while $D_{i}^{\mathrm{Cpx} / \text { Melt }}$ values decrease with $\mathrm{T}, D_{\mathrm{Th}}^{\mathrm{Cpx} / \mathrm{Melt}} / D_{\mathrm{U}}^{\mathrm{Cpx} / \text { Melt }}$ ratios are relatively constant.

in which the final equilibrium state was approached from two different starting conditions, to demonstrate that the final equilibrium is independent of path. An experiment in which the final pressure-temperature conditions $\left(1440{ }^{\circ} \mathrm{C}, 2.5 \mathrm{GPa}\right)$ were approached starting from ambient conditions produced a mineral assemblage of $\mathrm{Cpx}+$ $\mathrm{Gt}+\mathrm{Sp}$ with $D_{\mathrm{U}}^{\mathrm{Cpx} / \mathrm{Melt}}=0.017 \pm 0.002$ and $D_{\mathrm{Th}}^{\mathrm{Cpx} / \mathrm{Melt}}=$ $0.015 \pm 0.002$. A second experiment was conducted at $2.5 \mathrm{GPa}$ in which the charge was initially held at $1340{ }^{\circ} \mathrm{C}$ for $6 \mathrm{~h}$, then heated at $1{ }^{\circ} \mathrm{C} / \mathrm{s}$ to $1440{ }^{\circ} \mathrm{C}$ and held for $72 \mathrm{~h}$. This experiment produced a mineral assemblage of $\mathrm{Cpx}+$ $\mathrm{Sp}$, with $D_{\mathrm{U}}^{\mathrm{Cpx} / \mathrm{Melt}}=0.016 \pm 0.002$ and $D_{\mathrm{Th}}^{\mathrm{Cpx} / \text { Melt }}=0.015 \pm$ 0.001 . The $\mathrm{Fe} / \mathrm{Mg}$ exchange coefficients for $\mathrm{Cpx}$ and melt for these experiments are the same within analytical 


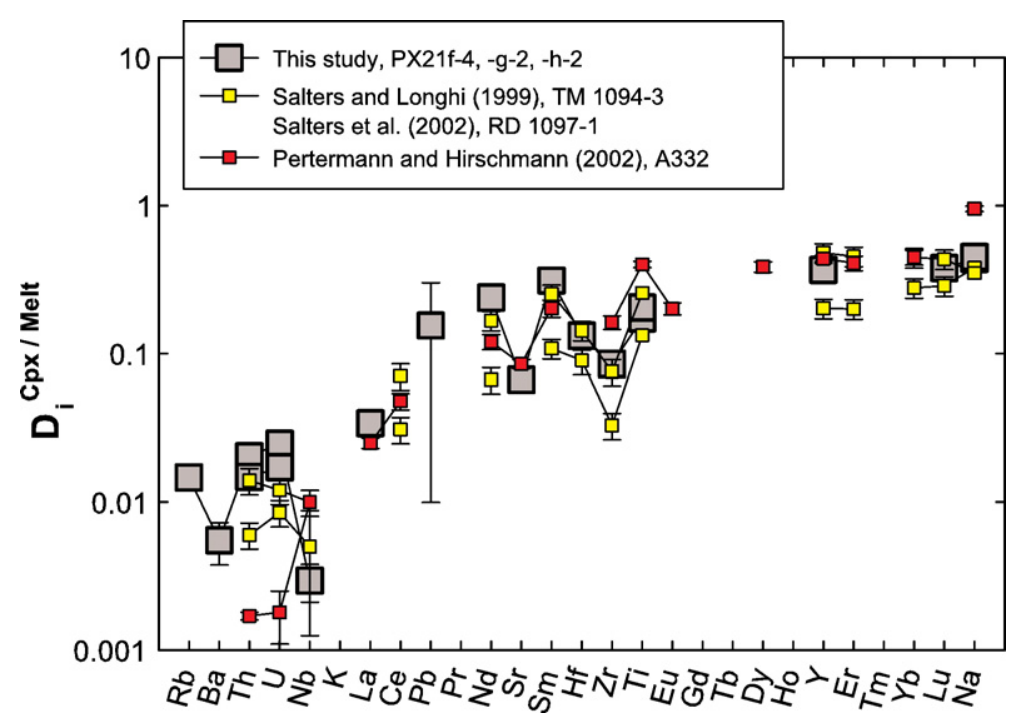

Fig. 2. Spider diagram showing combined Cpx-melt partition coefficients from experiments PX21g-2 and PX21h-2, in order of increasing compatibility (Hofmann, 1988). Data from Pertermann and Hirschmann (2002), Salters and Longhi (1999), and Salters et al. (2002) are shown for comparison between our experiments and eclogite and peridotite partitioning data from the literature. Note that the element ordering of Hofmann (1988) has been retained even for cases where no partitioning data are available in order to avoid the appearance of apparent compatibility anomalies.

uncertainty $(0.315 \pm 0.004$ versus $0.306 \pm 0.007)$. Therefore, while the absence of $\mathrm{Gt}$ in the second experiment indicates that an equilibrium mineral assemblage was not achieved, the experimental duration was adequate to attain equilibrium element distribution between minerals and melts.

\subsection{Henry's law}

In order to analyze the experimental products by SIMS, it was necessary to dope the starting compositions at levels significantly higher than those found in natural basalts. Previous trace element partitioning studies have demonstrated adherence to Henry's Law at concentration levels ranging from $100 \mathrm{ppm}$ to as high as 2 wt.\% (Grutzeck et al., 1974; Nicholls and Harris, 1980; Ray et al., 1983; Gallahan and Nielsen, 1992). The total trace element contents of our silicate melts $(\sim 1$ wt. $\%)$ fall well below the expected upper limit for Henry's law, such that no deviation from Henrian behavior is expected. While we did not carry out an explicit test of Henry's law, there are no systematic differences among experiments carried out using different concentrations of $\mathrm{U}$ and $\mathrm{Th}$, and our partition coefficients are in general agreement with literature values determined over a range of doping levels. On the basis of these comparisons, we conclude that our experiments were carried out at concentration levels within the range of Henrian behavior and that our results are appropriate for modeling natural systems.

\section{Discussion}

\subsection{Partitioning of $U$ and Th during partial melting of garnet pyroxenite}

The equilibrium partitioning of incompatible trace elements such as $U$ and Th during partial melting is governed at equilibrium by the equivalence of chemical potentials. Because of this, $D_{i}^{\text {Mineral/Melt }}$ values depend on both the pressure-temperature conditions at which partial melting takes place and the compositions of both the minerals in the source rock and the partial melt. As noted in the introduction, there is isotopic evidence to suggest that heterogeneity exists in the source region of OIB (Zindler and Hart, 1986), it is plausible that lithologic heterogeneity is also present and may be a source for enriched lavas (Hirschmann and Stolper, 1996; Lundstrom et al., 1999), and silica-poor garnet pyroxenite is a viable source rock for producing the major element composition of alkaline OIB lavas (Hirschmann et al., 2003; Kogiso et al., 2003, 2004). Melting of garnet pyroxenite begins at higher pressures and temperatures than peridotite, and the compositions of both Cpx and Gt in pyroxenite are different than in lherzolite. These factors have the potential to produce differences in both the absolute and the relative compatibilities of $U$ and Th during partial melting that could create identifiable differences in secular disequilibria patterns in melts. Here we use results from our partitioning experiments to quantify the influence 


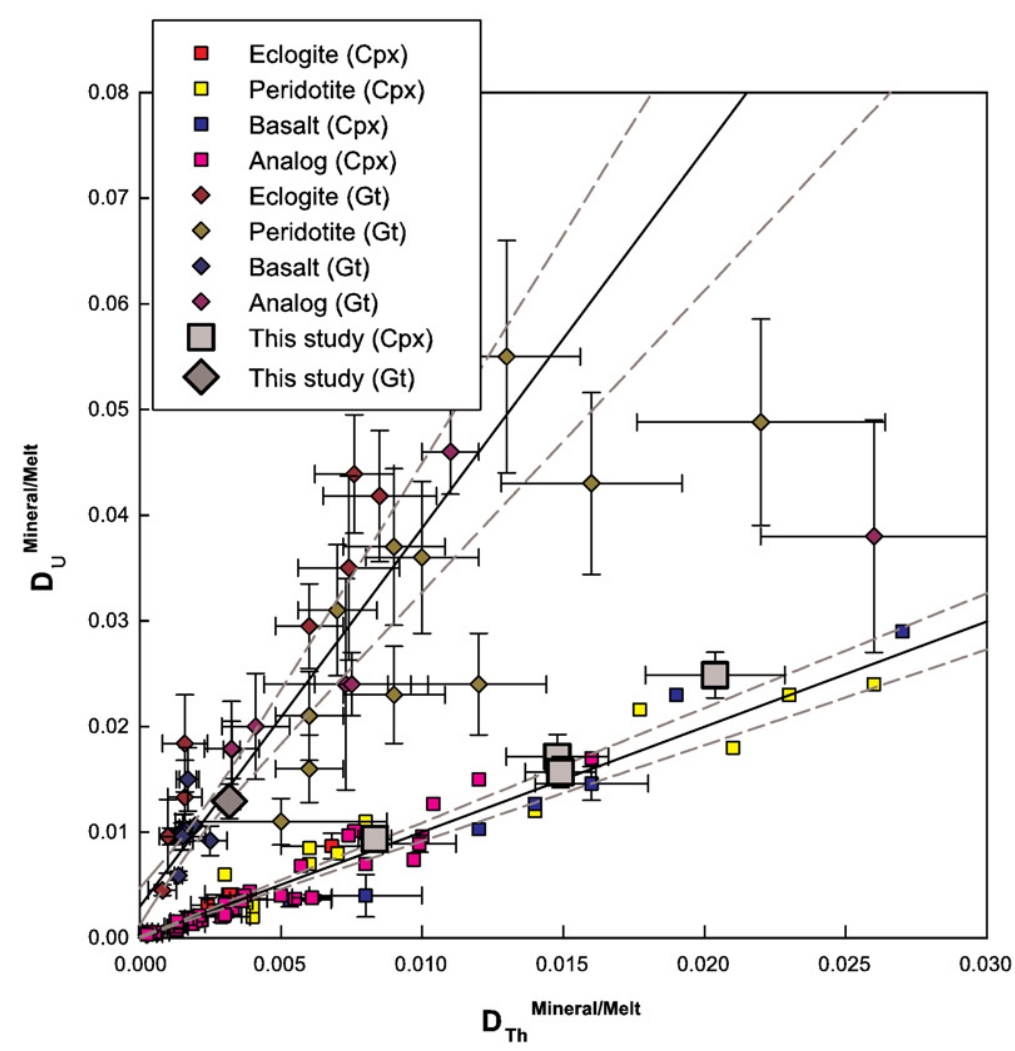

Fig. 3. $D_{\mathrm{Th}}^{\mathrm{Mineral} / \mathrm{Melt}}$ vs. $D_{\mathrm{U}}^{\mathrm{Minera} / \mathrm{Melt}}$ for Cpx and Gt data from this study and from the literature (Benjamin et al., 1980; La Tourette and Burnett, 1992; Beattie, 1993a,b; La Tourette et al., 1993; Hauri et al., 1994; Lundstrom et al., 1994; Salters and Longhi, 1999; van Westrenen et al., 1999; Wood et al., 1999; van Westrenen et al., 2000; Landwehr et al., 2001; Pertermann and Hirschmann, 2002; Salters et al., 2002; McDade et al., 2003; Pertermann et al., 2004), filtered to show only those experiments with oxygen fugacity at least 1 log unit more reduced than the fayalite-magnetite-quartz buffer

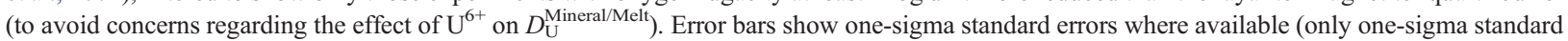
deviations were available from Benjamin et al. (1980) and McDade et al. (2003), and only estimated uncertainties were available from Salters and Longhi (1999) and Salters et al. (2002)). Results from double error regressions (solid lines) and 95\% confidence envelopes (dashed lines) for Cpx and Gt are shown. Although all data are shown, only $D_{i}^{\text {Mineral/Melt }}$ values with reported errors are included in the regressions. The Gt trend follows a steeper slope than the Cpx data, as discussed in Section 4.1 of the text.

of some of these factors on $D_{\mathrm{Th}}^{\text {Mineral/Melt }}, D_{\mathrm{U}}^{\mathrm{Mineral} / \text { Melt }}$, and $D_{\mathrm{Th}}^{\mathrm{Mineral} / \mathrm{Melt}} / D_{\mathrm{U}}^{\mathrm{Mineral} / \mathrm{Melt}}$ ratios during partial melting of garnet pyroxenite. While the composition of the melt can also influence the magnitude of $D_{i}^{\text {Mineral/Melt }}$, it is unlikely to change relative compatibilities of isovalent cations with the same charge and similar cationic radii (e.g. Landwehr et al., 2001; Gaetani, 2004).

Given that $\mathrm{U}^{4+}$ and $\mathrm{Th}^{4+}$ have the same valence state at oxygen fugacity conditions thought to be prevalent in the upper mantle, the variable most likely to influence the relative compatibilities of these elements during partial melting is the size of the lattice site onto which they substitute. Wood et al. (1999) pointed out that for spinel lherzolite of a given bulk composition, Cpx becomes increasingly poorer in $\mathrm{Ca}^{2+}$ and richer in $\mathrm{Al}^{3+}$ with increasing pressure along the peridotite solidus, and that this likely results in a decrease in the mean size of the Cpx M2 site (designated as $r_{0}$ in the lattice strain equation of Blundy and Wood (1994)). Because the cationic radius of $\mathrm{U}^{4+}$ $(1.00 \AA)$ is slightly less than that of $\mathrm{Th}^{4+}(1.05 \AA)$ in VIIIfold coordination (Shannon, 1976), this compositional change should produce a progressive decrease in the compatibility of $\mathrm{Th}^{4+}$ relative to $\mathrm{U}^{4+}$ in spinel lherzolite with increasing depth in the upper mantle. Landwehr et al. (2001) experimentally demonstrated the influence of $\mathrm{Cpx}$ composition on $D_{\mathrm{Th}}^{\mathrm{Cpx} / \mathrm{Melt}} / D_{\mathrm{U}}^{\mathrm{Cpx} / \mathrm{Melt}}$ in the simplified system $\mathrm{CaO}-\mathrm{MgO}-\mathrm{Al}_{2} \mathrm{O}_{3}-\mathrm{SiO}_{2}-$ $\mathrm{Na}_{2} \mathrm{O}$, producing $D_{\mathrm{Th}}^{\mathrm{Cpx} / \mathrm{Melt}} / D_{\mathrm{U}}^{\mathrm{Cpx} / \text { Melt }}$ ratios ranging from $1.64 \pm 0.14$ for relatively $\mathrm{CaO}$-rich $(23.08 \pm$ 0.19 wt.\%), $\mathrm{Al}_{2} \mathrm{O}_{3}$-poor $(1.27 \pm 0.04$ wt.\%) $\mathrm{Cpx}$ with $r_{0}=1.031 \AA$, to $0.58 \pm 0.11$ for a $\mathrm{CaO}$-poor $(6.3 \pm$ 0.3 wt.\%), $\mathrm{Al}_{2} \mathrm{O}_{3}$-rich (19.5 \pm 0.4 wt.\%) $\mathrm{Cpx}$ with $r_{0}=0.952 \AA$.

To evaluate the possibility that $\mathrm{Cpx}$ and Gt compositional differences related to differing lithologies also cause systematic differences in $\mathrm{U} / \mathrm{Th}$ fractionation 


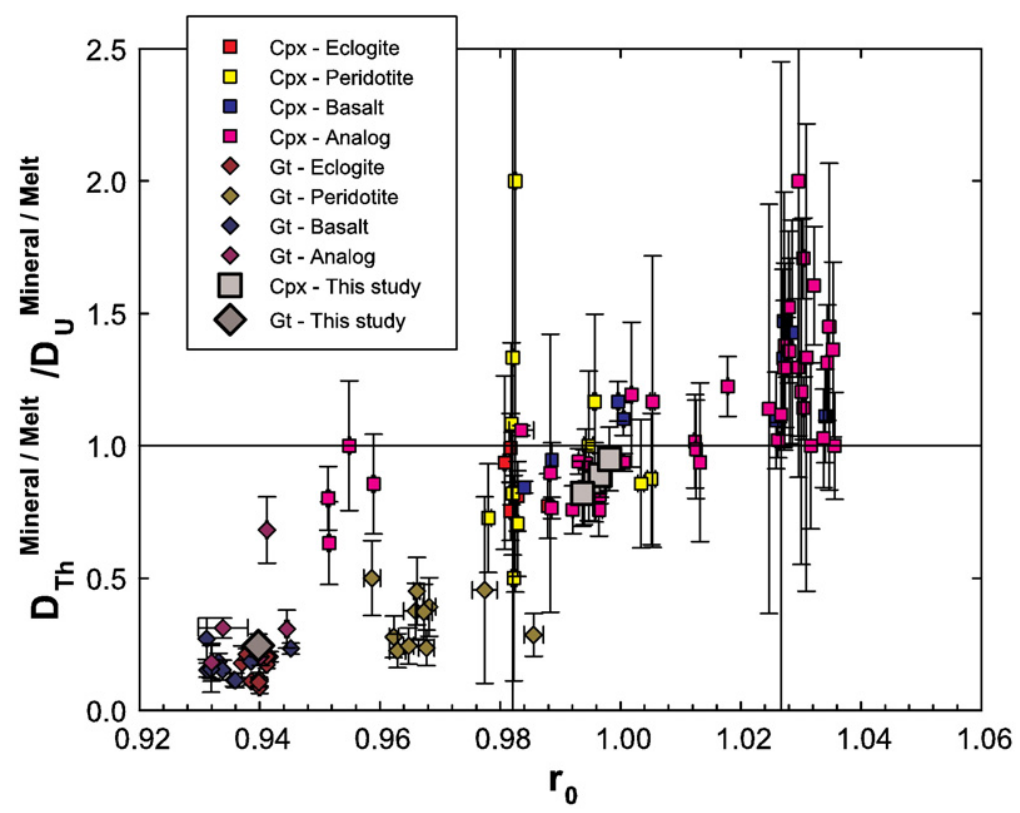

Fig. 4. Plot showing relationships between calculated $r_{0}$ values and $D_{\mathrm{Th}}^{\mathrm{Mineral} / \mathrm{Melt}} / D_{\mathrm{U}}^{\mathrm{Mineral} / \mathrm{Melt}}$ ratios for both Cpx and Gt; data set and error bars as in Fig. 3. Note that for a given $r_{0}$ value $D_{\mathrm{Th}}^{\mathrm{Mineral} / \mathrm{Melt}} / D_{\mathrm{U}}^{\mathrm{Mineral} / \mathrm{Melt}}$ ratios are significantly lower for Gt than for Cpx.

during partial melting, we compared $\mathrm{U}$ and Th partition coefficients determined for $\mathrm{Cpx}$ and $\mathrm{Gt}$ from our experiments with those determined in previous studies for partial melting of eclogite and peridotite and from near-liquidus experiments on basalts (Figs. 3 and 4). The nominal radii $\left(r_{0}\right)$ of the Cpx M2 and Gt X lattice sites were calculated as a function of mineral composition for our partitioning experiments and those from the literature using Equation 15 of Wood and Blundy (1997) and Equation 2 of van Westrenen et al. (2001), respectively. Applying these values to understand the geochemical behavior of $\mathrm{U}^{4+}$ and $\mathrm{Th}^{4+}$ requires the assumption that $r_{0}^{3+}=r_{0}^{4+}$, but the uncertainty involved with this approximation is small (e.g. (Wood et al., 1999; Landwehr et al., 2001; Blundy and Wood, 2003).

There are no obvious correlations between $r_{0}$ and $D_{\mathrm{Th}}^{\mathrm{Mineral} / \mathrm{Melt}}$ or $D_{\mathrm{U}}^{\mathrm{Mineral} / \mathrm{Melt}}$ for either Cpx or Gt. This is not surprising, given that the magnitudes of both partition coefficients depend upon pressure, temperature, and melt composition in addition to mineral composition. However, there are statistically significant correlations between $D_{\mathrm{Th}}^{\mathrm{Mineral} / \mathrm{Melt}}$ and $D_{\mathrm{U}}^{\mathrm{Mineral} / \text { Melt }}$ for both Cpx and Gt, with an especially strong relationship for Cpx (Fig. 3):

$D_{\mathrm{U}}^{\mathrm{Cpx} / \mathrm{Melt}}=1.0 \pm 0.9 \times D_{\mathrm{Th}}^{\mathrm{Cpx} / \mathrm{Melt}}+0.00006 \pm 0.00008$

$D_{\mathrm{U}}^{\mathrm{Gt} / \text { Melt }}=3.6 \pm 0.7 \times D_{\mathrm{Th}}^{\mathrm{Gt} / \mathrm{Melt}}+0.0030 \pm 0.0017$ where stated uncertainties are $2 \sigma$. For $\mathrm{Cpx}$, the slope of this correlation is 1.0 , reflecting the small variation around a value of 1 exhibited by the $D_{\mathrm{Th}}^{\mathrm{Cpx} / \mathrm{Melt}} / D_{\mathrm{U}}^{\mathrm{Cpx} / \text { Melt }}$ ratio. As the individual compatibilities of $U$ and $T h$ in Cpx increase, their relative compatibilities do not change significantly. In the case of $\mathrm{Gt}, D_{\mathrm{U}}^{\mathrm{Gt} / \mathrm{Melt}}$ increases approximately 4 times faster than $D_{\mathrm{Th}}^{\mathrm{Gt} / \mathrm{Melt}}$, so that the $D_{\mathrm{Th}}^{\mathrm{Gt} / \text { Melt }} / D_{\mathrm{U}}^{\mathrm{Gt} / \text { Melt }}$ ratio is typically $\sim 0.25$ (note that Eq. (2) has a non-zero intercept, an indication that this relationship is likely to be curved). There appears to be no systematic change in compatibility of either $U$ or Th among the different lithologies (pyroxenite, eclogite, or peridotite) for $\mathrm{Cpx}$. This may not be true for Gt, however, where $\mathrm{U}^{4+}$ and $\mathrm{Th}^{4+}$ appear to be more compatible during partial melting of peridotite relative to eclogite or pyroxenite.

Fig. 4 is a plot of $r_{0}$ versus $D_{\mathrm{Th}}^{\mathrm{Mineral} / \text { Melt }} / D_{\mathrm{U}}^{\mathrm{Minera} / \text { Melt }}$ ratio for experimentally produced $\mathrm{Cpx}$ and Gt. From this comparison it can be seen that the $D_{\mathrm{Th}}^{\mathrm{Mineral} / \mathrm{Melt}} / D_{\mathrm{U}}^{\mathrm{Mineral} / \text { Melt }}$ ratio increases systematically with increasing $r_{0}$, as suggested for Cpx by Wood et al. (1999), and that this increase can be driven by bulk composition as well as variations in pressure-temperature conditions. For Cpx, the relative compatibilities of $U$ and $T h$ switch at an $r_{0}$ value $\sim 1.00 \AA$, comparable to the cationic radius of $\mathrm{U}^{4+}$. Clinopyroxenes produced in our experiments are characterized by a narrow range of $r_{0}$ values $(0.994-$ $0.998 \AA$ ) that fall near the middle of the overall range for Cpx from partitioning experiments ( 0.951 to 
$1.036 \AA$; Fig. 4), and a mean $D_{\mathrm{Th}}^{\mathrm{Cpx} / \text { Melt }} / D_{\mathrm{U}}^{\mathrm{Cpx} / \text { Melt }}$ ratio of $0.88 \pm 0.05$. Clinopyroxenes with compositions relevant to eclogite partial melting have M2 lattice sites with $r_{0}$ from 0.981 to $0.988 \AA$, significantly smaller than for Cpx from silica-poor garnet pyroxenite, and are characterized by $D_{\mathrm{Th}}^{\mathrm{Cpx} / \mathrm{Melt}} / D_{\mathrm{U}}^{\mathrm{Cpx} / \mathrm{Melt}}$ ratios of 0.77 to 1.00 . Clinopyroxene from experiments carried out to investigate partitioning during peridotite partial melting have $r_{0}$ values from 0.978 to $1.005 \AA$, and $D_{\mathrm{Th}}^{\mathrm{Cpx} / \mathrm{Melt}} / D_{\mathrm{U}}^{\mathrm{Cpx} / \text { Melt }}$ ratios of 0.50 to 2.0 . These are substantially broader ranges than for either pyroxenite or eclogite Cpx and may, in part, reflect the broader range of pressure-temperature conditions of these experiments. Clinopyroxene from partitioning experiments on near-liquidus basalts have the widest range of $r_{0}$ values $(0.984$ to $1.030 \AA)$, with $D_{\mathrm{Th}}^{\mathrm{Cpx} / \text { Melt }} / D_{\mathrm{U}}^{\mathrm{Cpx} / \text { Melt }}$ ratios of 0.83 to 2.0 , and define the upper end of the range for experiments on "natural" starting compositions. This is likely a reflection of their systematically higher $\mathrm{CaO}$ contents.

The $r_{0}$ values calculated for the Gt X site are smaller than the majority of those for the Cpx M2 site, with a narrower range of values (0.931 to $0.986 \AA)$. The $D_{\mathrm{Th}}^{\mathrm{Gt} / \text { Melt }} / D_{\mathrm{U}}^{\mathrm{Gt} / \text { Melt }}$ ratios are always much less than one (0.09-0.68 with a mean of 0.25). Garnets from pyroxenite melt $\left(r_{0}=0.940 \AA ; D_{\mathrm{Th}}^{\mathrm{Gt} / \mathrm{Melt}} / D_{\mathrm{U}}^{\mathrm{Gt} / \text { Melt }}=0.245\right)$, eclogite melt $\left(r_{0}=0.937\right.$ to $0.942 \AA ; D_{\mathrm{Th}}^{\mathrm{Gt} / \mathrm{Melt}} / D_{\mathrm{U}}^{\mathrm{Gt} / \mathrm{Melt}}=$ $0.087-0.211)$, and near-liquidus basalt $\left(r_{0}=0.931\right.$ to $\left.0.945 \AA ; D_{\mathrm{Th}}^{\mathrm{Gt} / \mathrm{Melt}} / D_{\mathrm{U}}^{\mathrm{Gt} / \text { Melt }}=0.113-0.271\right)$ partitioning experiments have $r_{0}$ values and $D_{\mathrm{Th}}^{\mathrm{Gt} / \text { Melt }} / D_{\mathrm{U}}^{\mathrm{Gt} / \text { Melt }}$ ratios comparable to one another. The $r_{0}$ values for $\mathrm{Gt}$ from experiments relevant to peridotite partial melting are significantly larger than for mafic lithologies, ranging from 0.959 to $0.986 \AA$, and $D_{\mathrm{Th}}^{\mathrm{Gt} / \text { Melt }} / D_{\mathrm{U}}^{\mathrm{Gt} / \text { Melt }}$ ratios $(0.226$ to $0.500)$ that tend to be larger. Therefore, as with $\mathrm{Cpx}$, Gt in mafic lithologies tend to produce large ${ }^{230} \mathrm{Th}$ excesses relative to peridotite.

In summary, the relationships shown in Figs. 3 and 4 strongly support the contention that, although other factors also contribute, the principal control on the relative compatibilities of $U$ and Th during partial melting is the size of the VIII-fold lattice sites in both $\mathrm{Cpx}$ and Gt. The size of the Cpx M2 site and of the Gt $\mathrm{X}$ site in eclogite and pyroxenite tend to be small relative to peridotite, such that bulk rock $D_{\mathrm{Th}} / D_{\mathrm{U}}$ ratios will tend to be higher. Therefore, for a given melting rate and extent of partial melting, mafic lithologies tend to produce larger ${ }^{230} \mathrm{Th}$ excesses than peridotites. As discussed in the next section, this effect is damped by the greater overall extents of partial melting experienced by eclogites and pyroxenites relative to peridotite.
4.2. Uranium series constraints on the role of garnet pyroxenite in the generation of alkaline OIB

Ocean island basalt lavas are characterized by a broad spectrum of trace element and isotopic compositions. Zindler and Hart (1986) and others have identified a variety of mantle components that mix to produce OIB globally. These components consist of a depleted end member, hypothesized to be the ambient depleted MORB mantle (DMM), and several distinct enriched components (EMI, EMII) characterized by time-integrated incompatible trace element enrichment as evidenced by their longlived radiogenic isotopic signatures.

The lithologic identity of the enriched component in the OIB source is hotly debated. Some studies suggest that the enriched signal is produced by crypticallymetasomatized ambient mantle peridotite (e.g. Workman et al., 2006), while others hypothesize that a mafic/ eclogitic source is responsible for this enrichment (e.g. Hirschmann and Stolper, 1996; Sobolev, 2000; Hirschmann et al., 2003). Because U-Th elemental fractionation is particularly sensitive to both mineral composition and the modal abundance of Gt in a lava's mantle source, measurements of $\left({ }^{230} \mathrm{Th} /{ }^{238} \mathrm{U}\right)$ disequilibria in OIBs provide an important means to address the question of source lithology.

Previously, Stracke et al. (1999) suggested that, on the basis of existing experimentally determined partition coefficients for $U$ and $T h$, partial melting of a mafic mantle lithology (e.g. pyroxenite, eclogite) could not generate significant degrees of ${ }^{230} \mathrm{Th}$ excess in lavas. Their $\left({ }^{230} \mathrm{Th} /{ }^{238} \mathrm{U}\right)$ values for pyroxenite melting were calculated using partitioning data from Hauri et al. (1994) with bulk $D_{\mathrm{Th}} / D_{\mathrm{U}}=0.96$ for pyroxenite and 0.83 for eclogite. These bulk partition coefficients generate only $5-20 \%{ }^{230} \mathrm{Th}$ excess, whereas the Salters and Longhi (1999) D values for U and Th used by Stracke et al. (1999) bulk $D_{\mathrm{U}} / D_{\mathrm{Th}} \sim 2$ ) could generate up to $\sim 100 \%{ }^{230}$ Th excess during partial melting of peridotite. While their use of the Salters and Longhi (1999) partition coefficients for peridotite could produce the necessary large ${ }^{230} \mathrm{Th}$ excesses, the $D_{i}^{\text {Mineral/Melt }}$ values they used for pyroxenite from Hauri et al. (1994) came from experiments on near-liquidus basalt. While the $D_{\mathrm{Th}}^{\mathrm{Gt} / \mathrm{Melt}} / D_{\mathrm{U}}^{\mathrm{Gt} / \text { Melt }}$ ratio from these experiments is comparable to pyroxenite ( 0.233 vs. 0.245$)$, the $D_{\mathrm{Th}}^{\mathrm{Cpx} / \mathrm{Melt}} / D_{\mathrm{U}}^{\mathrm{Cpx} / \text { Melt }}$ ratio is significantly higher $(1.13 \pm$ 0.03 vs. $0.88 \pm 0.05$ ), leading to ${ }^{230} \mathrm{Th}$ excesses that are too small. Therefore, they are not applicable to such an assessment.

The partition coefficients determined from our experiments are specific to partial melting of garnet 

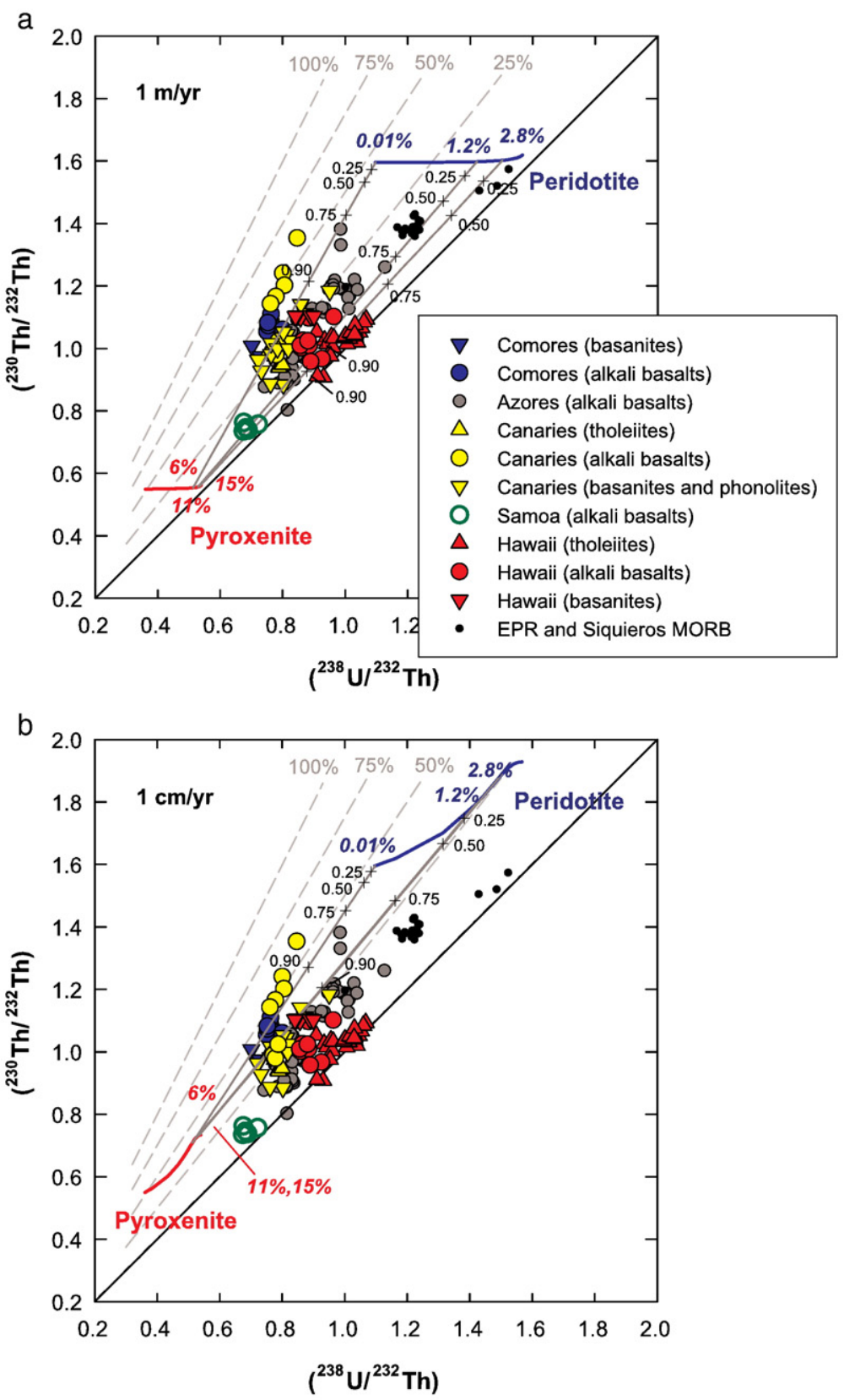

Fig. 5. $\left({ }^{238} \mathrm{U} /{ }^{232} \mathrm{Th}\right)$ vs. $\left({ }^{230} \mathrm{Th} /{ }^{232} \mathrm{Th}\right)$ equiline diagram for upwelling rates of (a) $1 \mathrm{~m} / \mathrm{yr}$ and (b) $1 \mathrm{~cm} / \mathrm{yr}$, showing chromatographic melting trajectories with residual porosities of $0.5 \%$ and binary mixing trends described in Section 4.2 of the text and the Appendix A. The curves labeled "Peridotite" and "Pyroxenite" show the progressive melting paths from each of those source lithologies, and the dark gray lines show mixing trends between melts of peridotitic (blue) and pyroxenitic (red) source lithologies at melt fractions reflecting the different depths to the solidii and productivities during upwelling. Tick or plus marks with labels show the fraction of pyroxenite in the binary pyroxenite-peridotite mixtures; note, however, that the precise position of these ticks is dependent on our choice of endmember values. Data from OIB rocks from Hawaii (Cohen and O’Nions, 1993; Sims et al., 1995; Cohen et al., 1996; Pickett and Murrell, 1997; Pietruszka, 1999; Sims et al., 1999), Samoa (Sims and Hart, 2006; Sims et al., in press), the Canaries (Sigmarsson et al., 1998; Lundstrom et al., 2003), the Azores (Turner et al., 1997; Widom et al., 1997; ClaudeIvanaj et al., 2001; Bourdon et al., 2005), and the Comores (Bourdon et al., 1998; Claude-Ivanaj et al., 1998) are plotted for comparison, together with East Pacific Rise (EPR) and Siquieros data (Lundstrom et al., 1999; Sims et al., 1999). Also shown for comparison are light gray dashed lines with labels indicating constant ${ }^{230} \mathrm{Th}$ excess. Note that because of the slopes of these lines, the enriched pyroxenitic source reaches higher values of ${ }^{230} \mathrm{Th}$ excess than the depleted peridotitic source. 
pyroxenite and thus provide an important test of its effect on $\left({ }^{230} \mathrm{Th} /{ }^{238} \mathrm{U}\right)$ disequilibria formed during OIB genesis. Here we use our partitioning data to evaluate the role of mixing of peridotite and garnet pyroxenite melts in generating the $\mathrm{U}-\mathrm{Th}, \mathrm{Sm}-\mathrm{Nd}$, and $\mathrm{Nd}$ isotope systematics of OIB. In our calculations we consider the differences in productivities (Hirschmann and Stolper, 1996) of these two lithologic end member components (Fig. 5). Because of the short half-life of ${ }^{230} \mathrm{Th}(75.4 \mathrm{ka})$ relative to the timescales of melt generation and magma transport we also consider the effects of ${ }^{230} \mathrm{Th}$ ingrowth during the melt generation process using an analytic approximation (Sims et al., 1999) to the 1-dimensional chromatographic melting model of Spiegelman and Elliott (1993). The main parameters of our meltingmixing models are: (1) $D_{i}^{\text {Mineral/Melt }}$ values, (2) melt fraction, (3) solid mantle upwelling rate, (4) porosity of the melting region, and (5) mixing proportions (a detailed description of our melting/mixing calculations can be found in the supplemental information).

In contrast with the results of Stracke et al. (1999), calculations carried out using our new partition coefficients show that at the limit of melting (when $\mathrm{F}$ approaches zero) a garnet pyroxenite source generates slightly larger ${ }^{230} \mathrm{Th}$ excesses $(52 \%)$ than peridotite melting $(46 \%)$ using $D_{\mathrm{Th}}^{\text {Mineral/Melt }}$ and $D_{\mathrm{U}}^{\text {Mineral/Melt }}$ values from Salters et al. (2002) (see Table 2 in the Appendix for $D_{i}{ }^{\text {Mineral/Melt }}$ values and modes used). At slower upwelling rates $(1 \mathrm{~cm} / \mathrm{yr}),\left({ }^{230} \mathrm{Th} /{ }^{238} \mathrm{U}\right)$ disequilibria are maintained or even enhanced over the duration of upwelling because of ${ }^{230} \mathrm{Th}$ ingrowth (Fig. 5b), whereas for faster upwelling $(1 \mathrm{~m} / \mathrm{yr})$, the degree of melting exerts a stronger control over the amount of disequilibria generated (Fig. 5a). Because of the larger buoyancy flux beneath ocean islands like Hawaii, fast upwelling is more appropriate, and indeed several studies have now shown that $\mathrm{U}-\mathrm{Th}$ disequilibria and $\mathrm{U}-\mathrm{Pa}$ disequilibria in places like Hawaii can be described by time independent melting models (Sims et al., 1995; Elliott, 1997; Sims et al., 1999; Bourdon and Sims, 2003).

Using our understanding of relative melt productivities for the two lithologies and conservative estimates for productivity (Langmuir et al., 1992; Hirschmann and Stolper, 1996; Hirschmann et al., 1999; Asimow et al., 2001; Pertermann and Hirschmann, 2003), mixing trends were calculated between melt fractions for pyroxenite and peridotite that reflect the differences in onset of melting and relative productivities. When the large productivity predicted for mafic lithologies relative to peridotite is taken into account, the resulting mixing lines, shown in Fig. 5a, can explain a majority of the alkali OIB data (only the Canaries and Comores data require greater disequilibria than are generated by our model). The most enriched samples (i.e. Samoa) show small and uniform ${ }^{230} \mathrm{Th}$ excesses, while more depleted lavas (like MORB) have large and highly variable ${ }^{230} \mathrm{Th}$ excesses (e.g. Sims and Hart, 2006). While, in principle, the alkaline OIB data in Fig. 5 are consistent with partial melting of a mixed pyroxenite-peridotite mantle source lithology, it is important to note that the data could be equally well explained by binary mixing of melts from two peridotite sources with different isotopic and trace element signatures (i.e. mixing of partial melts from a 'normal' peridotitic source with those from a metasomatically enriched peridotite source).

Comparison of U-Th disequilibria with other trace element fractionations provides more definitive constraints on both melting processes and source lithologies. In Fig. 6 we compare U-Th disequilibria with the parameter $\alpha_{\mathrm{Sm}-\mathrm{Nd}}$ for several suites of oceanic basalts (where $\alpha_{\mathrm{Sm}-\mathrm{Nd}}=(\mathrm{Sm} / \mathrm{Nd})_{\text {lava }} /(\mathrm{Sm} / \mathrm{Nd})_{\text {source }}$,

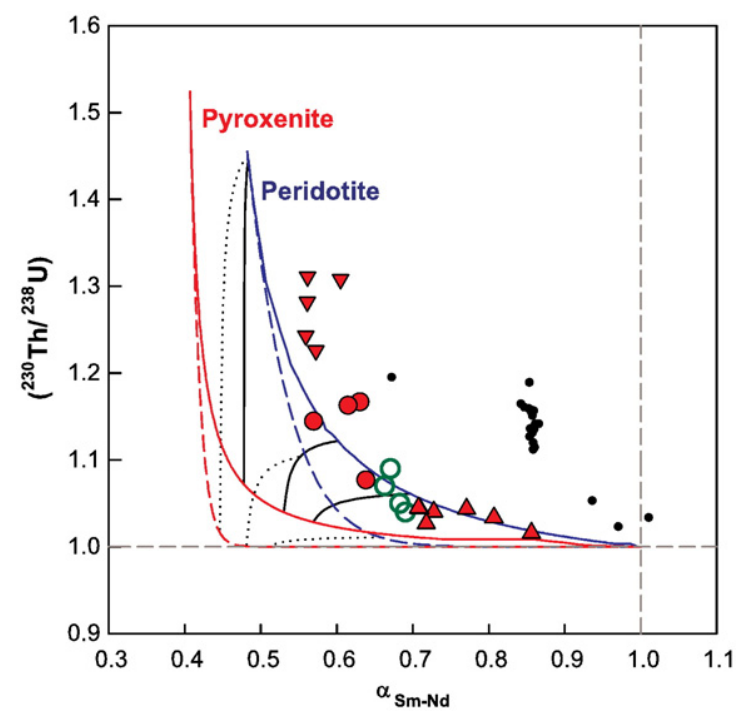

Fig. 6. $\alpha_{\mathrm{Sm}-\mathrm{Nd}}$ vs. $\left({ }^{230} \mathrm{Th} /{ }^{238} \mathrm{U}\right)$ (a) batch (solid) and fractional (dashed) melting trajectories for peridotite (blue line) and pyroxenite (red line), with binary peridotite-pyroxenite mixing trends shown as thin solid black (for batch melting) and dotted black (fractional) lines. Melt fractions for mixing are the same as in Fig. 5, as are symbols for Hawaii (Cohen and O'Nions, 1993; Sims et al., 1995; Cohen et al., 1996; Pickett and Murrell, 1997; Pietruszka, 1999; Sims et al., 1999), Samoa (Sims et al., 1999; Sims and Hart, 2006; Sims et al., in press), and MORB data (Lundstrom et al., 1999; Sims et al., 1999). Sm and $\mathrm{Nd} D_{i}^{\mathrm{Gt} / \text { Melt }}$ values are calculated as described in the text and supplemental information. The significantly reduced number of data points shown here relative to Fig. 5 reflects the smaller number of samples for which comprehensive $\mathrm{U}-\mathrm{Th}$ disequilibrium, $\mathrm{Sm}$ and $\mathrm{Nd}$ concentration, and $\mathrm{Nd}$ isotope data sets exist. 
and $(\mathrm{Sm} / \mathrm{Nd})_{\text {source }}$ is calculated using the sample's ${ }^{143} \mathrm{Nd} /{ }^{144} \mathrm{Nd}$ ratio and a $1.8 \mathrm{Ga}$ model age (see e.g. DePaolo, 1988; Sims et al., 1995)). This approach has been previously used to constrain melting processes in Hawaii (Sims et al., 1995; Elliott, 1997; Sims et al., 1999; Stracke et al., 1999), Samoa (Sims and Hart, 2006; Sims et al., in press), and the East Pacific Rise (Sims et al., 2002). While our new data provide constraints on $U$ and $T h$ partitioning, due to the nucleation difficulties associated with Gt, our experiments lack $D_{i}^{\text {Garnet/Melt }}$ values for $\mathrm{Sm}$ and $\mathrm{Nd}$. Thus, in order to examine silica-poor garnet pyroxenite melting for these systems, we apply our measured $D_{i}{ }^{\mathrm{Cpx} / \mathrm{Melt}}$ values for Th, $\mathrm{U}, \mathrm{Sm}$, and $\mathrm{Nd}$, while our measured $D_{i}^{\mathrm{Gt} / \mathrm{Melt}}$ values for $\mathrm{Th}$ and $\mathrm{U}$ are supplemented by $D_{\mathrm{Sm}}^{\mathrm{Gt} / \text { Melt }}$ and $D_{\mathrm{Nd}}^{\mathrm{Gt} / \mathrm{Melt}}$ values calculated for our pyroxenitic $\mathrm{Gt}$ compositions using the lattice strain model of van Westrenen et al. (2001) and Draper and van Westrenen (2007). Using these partitioning constraints and published partitioning data for peridotite (Salters et al., 2002), and applying them to forward batch and fractional melting, we find that existing Hawaii and Samoa data plot closer to the peridotite batch melting trend than that for pyroxenite or to fractional melting trends (Fig. 6). We also note, as has been found in previous OIB studies (e.g. Sims et al., 1995; Elliott, 1997; Sims et al., 1999), that the Hawaiian OIB data closely follow a batch melting trend and that $\mathrm{Th} / \mathrm{U}$ and $\mathrm{Sm} / \mathrm{Nd}$ fractionations are coupled, with the largest extents of $\mathrm{Th} / \mathrm{U}$ and $\mathrm{Sm} / \mathrm{Nd}$ fractionation occurring in the alkali basalts and basanites (inferred to be derived by low extents of melting) and the least extents of $\mathrm{Th} / \mathrm{U}$ and $\mathrm{Sm} / \mathrm{Nd}$ fractionation occurring in the tholeiites (inferred to be the largest melt fractions). As discussed above, this is because the inferred fast solid mantle upwelling rates beneath Hawaii do not allow for significant ${ }^{230} \mathrm{Th}$ ingrowth in the melting column, and the range in the extent of melting is large (i.e. from tholeiites to basanites), such that the degree of melting exerts a dominant control on the extent of fractionation for both $\mathrm{U}-\mathrm{Th}$ and $\mathrm{Sm}-\mathrm{Nd}$. Conversely, MORB data, shown for comparison, do not lie on this trend (Fig. 6), having much larger ${ }^{230} \mathrm{Th}$ excesses for a given $\mathrm{Sm} / \mathrm{Nd}$, and here ${ }^{230} \mathrm{Th}$ ingrowth is inferred to be important because of the slow upwelling rates beneath MOR.

It is generally assumed that mantle pyroxenite is isotopically distinct and from a source characterized by a long-term incompatible element enrichment. When comparing the Hawaiian lavas' Nd isotopic composition with U-Th disequilibria and $\mathrm{Sm} / \mathrm{Nd}$ fractionation, Stracke et al. (1999) observed that trends formed by Hawaiian lavas have an opposite slope from what would be

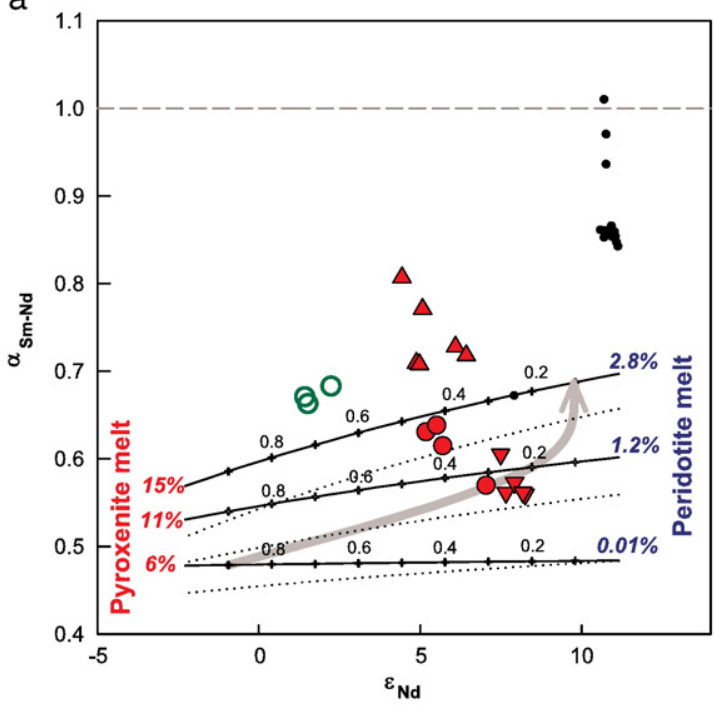

b

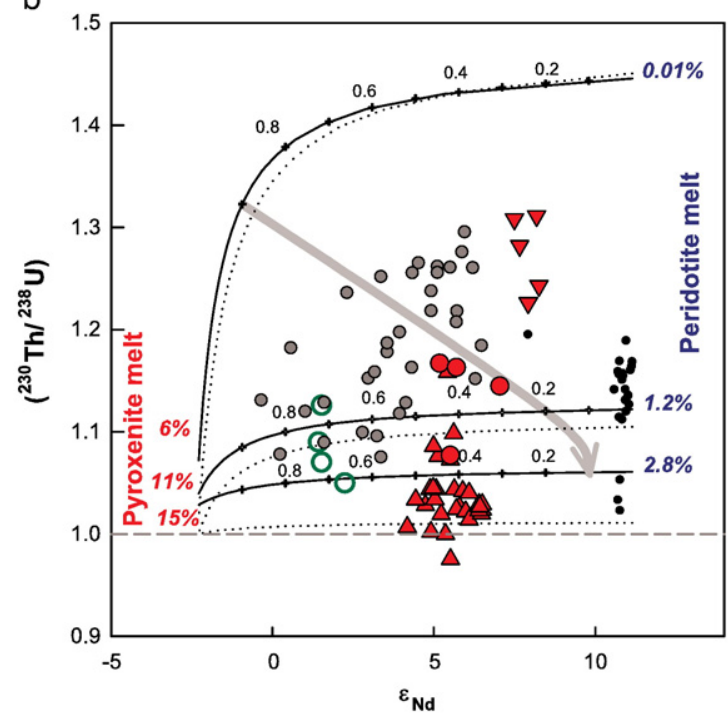

Fig. 7. $\varepsilon_{\mathrm{Nd}}$ vs. (a) $\alpha_{\mathrm{Sm}-\mathrm{Nd}}$ and (b) $\left({ }^{230} \mathrm{Th} /{ }^{238} \mathrm{U}\right)$, showing mixing lines for batch (solid) and fractional (dotted) melts of peridotite (blue) and pyroxenite (red) at melting fractions shown in blue and red. As in Fig. 5, tick marks with numbers on the batch melting curves show the fraction of pyroxenite melt in the mixtures. Hawaii (Cohen and O'Nions, 1993; Sims et al., 1995; Cohen et al., 1996; Pickett and Murrell, 1997; Pietruszka, 1999; Sims et al., 1999), Samoa (Sims and Hart, 2006; Sims et al., in press), Azores (Turner et al., 1997; Widom et al., 1997; Claude-Ivanaj et al., 2001; Bourdon et al., 2005), and MORB data (Lundstrom et al., 1999; Sims et al., 1999) are shown for comparison; symbols as in Fig. 5. Light gray arrows show the direction of progressive melting in an upwelling column with $\sim 2 \%$ pyroxenite in the source. Hawaiian, Azores, and Samoan data form a trend counter to what would be expected for progressive melting, as also observed in Stracke et al. (1999). 
expected from progressive melting and mixing of melts from two different lithologies in a melting column. Using our new pyroxenitic partition coefficients for $U$ and $\mathrm{Th}$ and the calculated values for $\mathrm{Sm} / \mathrm{Nd}$ described above and in the supplemental material, we find that our model melting and mixing curves give results consistent with the Stracke et al. (1999) predictions. As demonstrated in Fig. 7, the OIB data fall along a trend counter to the direction expected for progressive melting of a source with a fixed quantity of pyroxenite present. As proposed by Stracke et al. (1999), melting a peridotite with enriched signatures, and mixing those melts with melts of a deleted, "normal" peridotite, is an alternative explanation for the trends seen in the Hawaiian, Azores, and Samoan data sets.

\section{Conclusions}

Previous experimental studies of $U$ and Th partitioning have been conducted for peridotites, eclogites, and basaltic melt compositions, and to this data set we add new measurements for $\mathrm{Cpx}$ and Gt coexisting in a silica-poor garnet pyroxenite melt. At $1420-1450{ }^{\circ} \mathrm{C}$ and $2.5 \mathrm{GPa}$, our starting composition PX21, representing a $21 \%$ melt of the silica poor garnet pyroxenite MIX1G after Hirschmann et al. (2003), was found to have $D_{\mathrm{Th}}^{\mathrm{Cpx} / \mathrm{Melt}} / D_{\mathrm{U}}^{\mathrm{Cpx} / \text { Melt }}=0.82 \pm$ 0.12 to $0.95 \pm 0.12$ and $D_{\mathrm{Th}}^{\mathrm{Gt} / \text { Melt }} / D_{\mathrm{U}}^{\mathrm{Gt} / \text { Melt }}=0.25 \pm 0.04$.

These new data provide a quantitative test for viability of pyroxenite in the mantle source of OIB. Taking into account depth to solidi and variable productivities, we conclude that chromatographic and batch melts of silica-poor garnet pyroxenite and ambient peridotite can mix to generate most of the observed ${ }^{238} \mathrm{U}-{ }^{230}$ Th disequilibria. However, Hawaiian, Samoan, and Azores lavas form trends in trace element fractionation vs. radiogenic isotope space with slopes counter to expected progressive melting trends, suggesting that metasomatised peridotite could better explain the inferred isotopic enrichment in the source of these lavas. Further testing with new data from other ocean island settings may help to further constrain the role of garnet pyroxenite in global OIB production.

\section{Acknowledgements}

We are grateful to J. Blundy and M. Hirschmann for providing constructive reviews that improved the final version of the paper. N. Shimizu and N. Chatterjee are thanked for providing guidance with SIMS and electron microprobe analyses, respectively. This work was supported by the National Science Foundation under grants no.
OCE-0118198 to G. Gaetani and OCE-0422278 to K. Sims.

\section{Appendix A}

In Section 4.2, we apply the chromatographic melting model of Spiegelman and Elliott (1993) (Fig. 5). Calculations were carried out using our experimentally determined partition coefficient values for garnet pyroxenite partial melting $\left(D_{\mathrm{Th}}^{\mathrm{Cpx} / \text { Melt }}=0.015, D_{\mathrm{U}}^{\mathrm{Cpx} / \text { Melt }}=0.017, D_{\mathrm{Th}}^{\mathrm{Gt} / \text { Melt }}=\right.$ 0.0032 , and $D_{\mathrm{U}}^{\mathrm{Gt} / \mathrm{Melt}}=0.013$ ) and partitioning data from Salters and Longhi (1999) and Salters et al. (2002) for peridotite partial melting $\left(D_{\mathrm{Th}}^{\mathrm{Cpx} / \text { Melt }}=0.004, D_{\mathrm{U}}^{\mathrm{Cpx} / \mathrm{Melt}}=\right.$ $0.003, D_{\mathrm{Th}}^{\mathrm{Gt} / \mathrm{Melt}}=0.017, D_{\mathrm{U}}^{\mathrm{Gt} / \mathrm{Melt}}=0.038, D_{\mathrm{Th}}^{\mathrm{O} / \mathrm{Melt}}=$ $0.0005, D_{\mathrm{U}}^{\text {OlMelt }}=0.00005, D_{\mathrm{Th}}^{\text {Opx Melt }}=0.009$, and $D_{\mathrm{U}}^{\text {Opx/Melt }}=$ 0.008 , where Ol refers to olivine and Opx to orthopyroxene; see Table 2 in the Appendix). We use a porosity of $0.5 \%$ and endmember upwelling rates of $1 \mathrm{~m} / \mathrm{yr}$ and $1 \mathrm{~cm} / \mathrm{yr}$ to demonstrate the competing effects of upwelling and degree of melting in generating ${ }^{230} \mathrm{Th}-{ }^{238} \mathrm{U}$ disequilibria, since ingrowth, in addition to U-Th fractionation, accounts for much of the disequlibria produced at low upwelling rates (Sims et al., 1995; Elliott, 1997; Sims et al., 1999; Bourdon et al., 2006). To roughly allow for (1) the larger degrees of melting achieved by pyroxenite and (2) melting to continue slightly beyond the largest melt fractions in our binary mixtures (see below), we assign maximum degrees of melting of 0.1 for the peridotite and 0.2 for the pyroxenite (as shown below. We chose peridotite mineral modes of $8 \% \mathrm{Cpx}, 12 \% \mathrm{Gt}, 59 \% \mathrm{Ol}$, and $21 \%$ Opx (Table 2 in the Appendix), for parallel comparison with relevant U-series studies such as Sims et al. (1995, 1999).

While other studies have placed eclogite and pyroxenite solidi $12-50 \mathrm{~km}$ deeper than the peridotite solidus (Hirschmann and Stolper, 1996; Pertermann and Hirschmann, 2003; Kogiso et al., 2004), Kogiso et al. (2003) determined the MIX1G solidus to be less than $50{ }^{\circ} \mathrm{C}$ below the peridotite solidus, which, using typical solidus slopes of $120^{\circ} \mathrm{C} / \mathrm{GPa}$ for both pyroxenite and peridotite, places the MIX1G solidus only $6.5 \mathrm{~km}$ below the onset of peridotite melting.

We estimate that $40 \% \mathrm{Gt}$ is present in pyroxenite at $3.4 \mathrm{GPa}$, or $106.5 \mathrm{~km}$ depth $(6.5 \mathrm{~km}$ below the peridotite solidus in a $100 \mathrm{~km}$ melting column; see Table 2 in the Appendix for mineral modes) on the basis of previous experimental results for the MIX1g composition. Calculations for pyroxenite mineral modes coexisting with a $19 \%$ melt of MIX1g at $5 \mathrm{GPa}$ show a significantly greater abundance of Gt than Cpx (Kogiso et al., 2003). Similar calculations for experiments from Hirschmann 
et al. (2003) demonstrate that almost no Gt is present after $14 \%$ melting at $2 \mathrm{GPa}$. Mass balance calculations for the remaining melt in these two experiments suggest that at high pressure, almost $60 \% \mathrm{Gt}$ is present on the solidus, while at $2 \mathrm{GPa}$ less than $10 \%$ is present.

We chose initial $\left({ }^{238} \mathrm{U} /{ }^{232} \mathrm{Th}\right)$ and $\left({ }^{230} \mathrm{Th} /{ }^{232} \mathrm{Th}\right)$ ratios for the pyroxenite endmember component using the non-linear regression of Samoan data in Sims and Hart (2006); Samoan lavas have the most enriched isotopic signatures and lowest $\left({ }^{238} \mathrm{U} /{ }^{232} \mathrm{Th}\right)$ of any OIB (0.6) (Sims and Hart, 2006; Sims et al., submitted for publication), and the Sims and Hart (2006) regression calculates $\mathrm{Th} / \mathrm{U}=5.1-5.5$ for the EM2 endmember component. East Pacific Rise lavas represent some of the most depleted MORB samples with the highest $\left({ }^{230} \mathrm{Th} /{ }^{232} \mathrm{Th}\right)$ and $\left({ }^{238} \mathrm{U} /{ }^{232} \mathrm{Th}\right)$ ratios (Lundstrom et al., 1999; Sims et al., 2002). Thus, for the peridotite endmember we use data from the most extreme EPR sample (with respect to $\varepsilon_{\mathrm{Nd}} ;\left({ }^{238} \mathrm{U} /{ }^{232} \mathrm{Th}\right)=1.6$ ). All sources begin in secular equilibrium.

Previous studies have observed that productivity is low for at least the first $2-3 \%$ of melting above the solidus for all compositions (Langmuir et al., 1992; Hirschmann and Stolper, 1996; Hirschmann et al., 1999; Asimow et al., 2001; Pertermann and Hirschmann, 2003). Productivity then increases rapidly with increasing extent of partial melting, until it reaches a maximum at the point of $\mathrm{Cpx}$ exhaustion; once $\mathrm{Cpx}$ is absent, productivity drops abruptly and climbs again slowly until another phase is exhausted, though productivity is probably low enough after Cpx exhaustion that melting does not proceed far beyond this point. Calculated productivities from Hirschmann et al. (1999) for fertile peridotite melting increase from $\sim 5 \%$ / GPa just above the solidus to $\sim 24 \% / \mathrm{GPa}$ at the point of Cpx exhaustion ( $\sim 18 \%$ melting). Due to their different solidi and melting intervals, pyroxenite experiences this increase at a different rate during upwelling, causing the pyroxenite to melt significantly more. Hirschmann and Stolper (1996) estimated that peridotite initially melts at $0.4 \% / \mathrm{km}$ and that pyroxenites melt $20-50 \%$ faster than this, and diffusive heating below the peridotite solidus generates an additional $0.6-3.9 \% / \mathrm{km}(17-120 \% / \mathrm{GPa})$ of melting for pyroxenites (Hirschmann and Stolper, 1996).

Based on studies by Pertermann and Hirschmann (2003) and Kogiso et al. (2003), we estimate that a MIX1G-type pyroxenite, which has a narrow melting interval of $\sim 100{ }^{\circ} \mathrm{C}$, would melt at a similar rate to eclogite near its solidus $(15 \% / \mathrm{GPa})$, and that diffusive heating could conservatively add another $15 \% / \mathrm{GPa}$ of melting. Over $6.5 \mathrm{~km}$ of upwelling, these productivities, if constant, would generate $6 \%$ melting. Because MELTS can overestimate melting (e.g. Hirschmann et al., 1999), we use very conservative productivity estimates and suggest that for the next $5 \mathrm{~km}$ productivity for the pyroxenite is as low as $20 \% / \mathrm{GPa}$. Concurrently, the peridotite begins melting with a near-solidus productivity of $5 \% / \mathrm{GPa}$ (Hirschmann et al., 1999); thus, after 5 more km of upwelling, pyroxenite has experienced $10.8 \%$ melting and peridotite $1.2 \%$. After a further $5 \mathrm{~km}$ of upwelling, with a higher pyroxenite productivity of $25 \% / \mathrm{GPa}$ and peridotite productivity of $10 \% / \mathrm{GPa}$, the pyroxenite source has melted $14.8 \%$ and the peridotite source $2.8 \%$. Mixing lines based on these calculations are shown and labeled with the respective melt fractions of each mixing melt in Figs. 5-7. Note that step-wise melting in this fashion necessarily underestimates what are probably continuously increasing productivities during upwelling, again making these estimates conservative in terms of each melting lithology's ability to fractionate trace elements during upwelling and melting.

To test the agreement of the U-Th modeling with other isotopic systems, we also applied batch, fractional, and chromatographic melting models to $\alpha_{\mathrm{Sm}-\mathrm{Nd}}$ (where $\alpha_{\mathrm{Sm}-\mathrm{Nd}}=(\mathrm{Sm} / \mathrm{Nd})_{\text {lava }} /(\mathrm{Sm} / \mathrm{Nd})_{\text {source, }}$, and $(\mathrm{Sm} / \mathrm{Nd})_{\text {source }}$ is calculated using the sample's ${ }^{143} \mathrm{Nd} /{ }^{144} \mathrm{Nd}$ ratio and a $1.8 \mathrm{Ga}$ model age) during melting of pyroxenite and peridotite (Fig. 6). Partition coefficient data for Sm and $\mathrm{Nd}$ are from Salters et al. (2002) for peridotite, and for pyroxenite we use our measurements for Cpx partitioning and calculate Gt partition coefficients from van Westrenen et al. (2001) and Draper and van Westrenen (2007). We chose source Sm and Nd concentrations for the depleted peridotite and enriched pyroxenite sources from the Workman et al. (2004) and Workman and Hart (2005) inversions for the DMM and EM2 endmembers, respectively. Other parameters for melting and mixing are the same as above. In Fig. 7, the same batch and fractional melting and mixing trends for $\alpha_{\mathrm{Sm}-\mathrm{Nd}}$ and $\left({ }^{230} \mathrm{Th} /{ }^{238} \mathrm{U}\right)$ are plotted against $\varepsilon_{\mathrm{Nd}}$.

\section{Appendix B. Supplementary data}

Supplementary data associated with this article can be found, in the online version, at doi:10.1016/j. eps1.2007.10.034.

\section{References}

Armstrong, J.T., 1988. Quantitative analysis of silicate and oxide minerals: comparison of Monte Carlo, ZAF, and $\phi(\rho \mathrm{z})$ procedures. In: Newbury, D.E. (Ed.), Microbeam Analysis - 1988. San Francisco Press, San Francisco, CA, pp. 239-246.

Asimow, P.D., Hirschmann, M.M., Stolper, E.M., 2001. Calculation of peridotite partial melting from thermodynamic models of minerals 
and melts. IV. Adiabatic decompression and the composition and mean properties of mid-ocean ridge basalts. J. Petrol. 42, 963-998.

Beattie, P., 1993a. The generation of uranium series disequilibria by partial melting of spinel peridotite; constraints from partitioning studies. Earth Planet. Sci. Lett. 117, 379-391.

Beattie, P., 1993b. Uranium-thorium disequilibria and partitioning on melting of garnet peridotitie. Nature 363, 63-65.

Benjamin, T., Heuser, W.R., Burnett, D.S., Seitz, M.G., 1980. Actinide crystal-liquid partitioning for clinopyroxene and $\mathrm{Ca} 3(\mathrm{PO} 4) 2$. Geochim. Cosmochim. Acta 44, 1251-1264.

Blundy, J.D., Wood, B.J., 1994. Prediction of crystal-melt partition coefficients from elastic moduli. Nature 372, 452-454.

Blundy, J.D., Wood, B.J., 2003. Mineral-melt partitioning of uranium, thorium, and their daughters. Reviews in Mineralogy, 52, pp. $59-123$.

Bourdon, B., Sims, K.W.W., 2003. U-series constraints on intraplate basaltic magmatism. Rev. Mineral. Petrol. 52, 215-254.

Bourdon, B., Zindler, A., Elliott, T., Langmuir, C.H., 1996. Constraints on mantle melting at mid-ocean ridges from global ${ }^{238} \mathrm{U} /{ }^{230} \mathrm{Th}$ disequilibria data. Nature 384, 231-235.

Bourdon, B., Joron, J.-L., Claude-Ivanaj, C., Allègre, C.J., 1998. UTh-Pa-Ra systematics for the Grande Comore volcanics: melting processes in an upwelling plume. Earth Planet. Sci. Lett. 164, 119-133.

Bourdon, B., Turner, S.P., Ribe, N.M., 2005. Partial melting and upwelling rates beneath the Azores from a U-series isotope perspective. Earth Planet. Sci. Lett. 239, 42-56.

Bourdon, B., Ribe, N.M., Stracke, A., Saal, A.E., Turner, S.P., 2006. Insights into the dynamics of mentle plumes from uranium-series geochemistry. Nature 444, 713-717.

Boyd, F.R., England, J.L., 1960. Apparatus for phase equilibrium studies at pressures up to $50 \mathrm{kbar}$ and temperatures up to $1750{ }^{\circ} \mathrm{C}$. J. Geophys. Res. 65, 741-748.

Claude-Ivanaj, C., Bourdon, B., Allègre, C.J., 1998. Ra-Th-Sr isotope systematics in Grande Comore Island: a case study of plumelithosphere interaction. Earth Planet. Sci. Lett. 164, 99-117.

Claude-Ivanaj, C., Joron, J.-L., Allègre, C.J., 2001. ${ }^{238} \mathrm{U}-{ }^{230} \mathrm{Th}-{ }^{226} \mathrm{Ra}$ fractionation in historical lavas from the Azores: long-lived heterogeneity versus metasomatism fingerprints. Chem. Geol. 176, 295-310.

Cohen, A.S., O'Nions, R.K., 1993. Melting rates beneath Hawaii: evidence from uranium series isotopes in recent lavas. Earth Planet. Sci. Lett. 120, 169-175.

Cohen, A.S., O’Nions, R.K., Kurz, M.D., 1996. Chemical and isotopic variations in Mauna Loa tholeiites. Earth Planet. Sci. Lett. 143, $111-124$.

DePaolo, D., 1988. Neodymium isotope geochemistry: An introduction.

Draper, D.S., van Westrenen, W., 2007. Quantifying garnet-melt trace element partitioning using lattice-strain theory: assessment of statistically significant controls and a new predictive model. Contrib. Mineral. Petrol. 154, 731-746.

Elliott, T., 1997. Fractionation of $U$ and Th during mantle melting: a reprise. Chem. Geol. 139, 165-183.

Gaetani, G.A., 2004. The influence of melt structure on trace element partitioning near the peridotite solidus. Contrib. Mineral. Petrol. $147,511-527$.

Gallahan, W.E., Nielsen, R.L., 1992. The partitioning of Sc, Y, and the rare earth elements between high-Ca pyroxene and natural mafic to intermediate lavas at 1 atmosphere. Geochim. Cosmochim. Acta 56, 2387-2404.

Grutzeck, M., Kridelbaugh, S., Weill, D.F., 1974. The distribution of $\mathrm{Sr}$ and REE between diopside and silicate liquid. Geophys. Res. Lett. 1, 273-275.
Hauri, E.H., 1996. Major-element variability in the Hawaiian mantle plume. Nature 382, 415-419.

Hauri, E.H., 2002. SIMS analysis of volatiles in silicate glasses, 2: isotopes and abundances in Hawaiian melt inclusions. Chem. Geol. $183,115-141$.

Hauri, E.H., Wagner, T.P., Grove, T.L., 1994. Experimental and natural partitioning of $\mathrm{Th}, \mathrm{U}, \mathrm{Pb}$, and other trace elements between garnet, clinopyroxene, and basaltic melts. Chem. Geol. 117, 149-166.

Hays, J.F., 1966. Lime-alumina-silica. Carnegie Institution of Washington Yearbook, 65, pp. 234-239.

Hirschmann, M.M., Stolper, E.M., 1996. A possible role for garnet pyroxenite in the origin of the "garnet signature" in MORB. Contrib. Mineral. Petrol. 124, 185-208.

Hirschmann, M.M., Asimow, P.D., Ghiorso, M.S., Stolper, E.M., 1999. Calculation of peridotite partial melting from thermodynamic models of minerals and melts. III. Controls on isobaric melt production and the effect of water on melt production. J. Petrol. 40, 831-851.

Hirschmann, M.M., Kogiso, T., Baker, M.B., Stolper, E.M., 2003. Alkalic magmas generated by partial melting of garnet pyroxenite. Geology 31, 481-484.

Hofmann, A.W., 1988. Chemical differentiation of the Earth: the relationship between mantle, continental crust, and oceanic crust. Earth Planet. Sci. Lett. 90, 297-314.

Johannes, W., Bell, P., Mao, H.K., Boettcher, A.L., Chipman, D.W., Hays, J.F., Newton, R.C., Seifert, F., 1971. An interlaboratory comparison of piston-cylinder pressure calibration using the albitebreakdown reaction. Contrib. Mineral. Petrol. 32, 24-38.

Kogiso, T., Hirschmann, M.M., 2001. Experimental study of clinopyroxenite partial melting and the origin of ultra-calcic melt inclusions. Contrib. Mineral. Petrol. 142, 347-360.

Kogiso, T., Hirschmann, M.M., Frost, D.J., 2003. High-pressure partial melting of garnet pyroxenite: possible mafic lithologies in the source of ocean island basalts. Earth Planet. Sci. Lett. 216, 603-617.

Kogiso, T., Hirschmann, M.M., Pertermann, M., 2004. High-pressure partial melting of mafic lithologies in the mantle. J. Petrol. 45, 2407-2422.

Landwehr, D., Blundy, J.D., Chamorro-Perez, E.M., Hill, E., Wood, B.J., 2001. U-series disequilibria generated by partial melting of spinel lherzolite. Earth Planet. Sci. Lett. 188, 329-348.

Langmuir, C.H., Klein, E.M., Plank, T., 1992. Petrological systematics of mid-ocean ridge basalts: constraints on melt generation beneath ocean ridges. Mantle Flow and Melt Generation at Mid-Ocean Ridges, Geophys. Monograph, 71, pp. 183-280.

Lassiter, J.C., Hauri, E.H., Reiners, P.W., Garcia, M.O., 2000. Generation of Hawaiian post-erosional lavas by melting of a mixed lherzolite/pyroxenite source. Earth Planet. Sci. Lett. 178, 269-284.

La Tourette, T.Z., Burnett, D.S., 1992. Experimental determination of U-partitioning and Th-partitioning between cpx and natural and synthetic basaltic liquid. Earth Planet. Sci. Lett. 110, 227-244.

La Tourette, T.Z., Kennedy, A.K., Wasserburg, G.J., 1993. Thoriumuranium fractionation by garnet: Evidence for a deep source and rapid rise of oceanic basalts. Science 261, 739-742.

Lundstrom, C.C., Shaw, H.F., Ryerson, F.J., Phinney, D.L., Gill, J.B., Williams, Q., 1994. Compositional controls on the partitioning of $\mathrm{U}, \mathrm{Th}, \mathrm{Ba}, \mathrm{Pb}, \mathrm{Sr}$, and $\mathrm{Zr}$ between cpx and haplobasaltic melts: implications for uranium series disequilibria in basalts. Earth Planet. Sci. Lett. 128, 407-423.

Lundstrom, C.C., Sampson, D.E., Perfit, M.R., Gill, J., Williams, Q., 1999. Insights into mid-ocean ridge basalt petrogenesis: U-series 
disequilibria from the Siqueiros Transform, Lamont Seamounts, and East Pacific Rise. J. Geophys. Res. 104, 13,035-13,048.

Lundstrom, C.C., Hoernle, K., Gill, J., 2003. U-series disequilibria in volcanic rocks from the Canary Islands: Plume versus lithospheric melting. Geochim. Cosmochim. Acta 67, 4153-4177.

McDade, P., Blundy, J.D., Wood, B.J., 2003. Trace element partitioning on the Tinaquillo Lherzolite solidus at $1.5 \mathrm{GPa}$. Phys. Earth Planet. Inter. 139, 129-147.

Nicholls, I.A., Harris, K.L., 1980. Experimental rare earth element partition coefficients for garnet, clinopyroxene, and amphibole coexisting with andesitic and basaltic liquids. Geochim. Cosmochim. Acta 44, 287-308.

Pertermann, M., Hirschmann, M., 2002. Trace-element partitioning between vacancy-rich eclogitic clinopyroxene and silicate melt. Am. Mineral. 87, 1365-1376.

Pertermann, M., Hirschmann, M., 2003. Partial melting experiments on MORB-like pyroxenite between 2 and $3 \mathrm{GPa}$ : Constraints on the presence of pyroxenite in basalt source regions from solidus location and melting rate. J. Geophys. Res. 108.

Pertermann, M., Hirschmann, M.M., Hametner, K., Günther, D., Schmidt, M.W., 2004. Experimental determination of trace element partitioning between garnet and silica-rich liquid during anhydrous partial melting of MORB-like eclogite. Geochem. Geophys. Geosyst. 5.

Pickett, D.A., Murrell, M.T., 1997. Observations of $\left({ }^{231} \mathrm{~Pa}\right) /\left({ }^{235} \mathrm{U}\right)$ disequilibrium in volcanic rocks. Earth Planet. Sci. Lett. 148, 259-271.

Pietruszka, A., 1999. The short-term geochemical evolution of Kilauea Volcano, Hawai'i (1790-1998). University of Hawaii.

Ray, G.L., Shimizu, N., Hart, S.R., 1983. An ion microprobe study of partitioning of trace elements between clinopyroxene and liquid in the system diopside-albite-anorthite. Geochim. Cosmochim. Acta 47, 2131-2140.

Salters, V.J.M., Longhi, J., 1999. Trace element partitioning during the initial stages of melting beneath mid-ocean ridges. Earth Planet. Sci. Lett. 166, 15-30.

Salters, V.J.M., Longhi, J.E., Bizimis, M., 2002. Near mantle solidus trace element partitioning at pressures up to $3.4 \mathrm{GPa}$. Geochem. Geophys. Geosyst. 3.

Shannon, R.D., 1976. Revised effective ionic radii and systematic studies of interatomic distances in halides and chalcogenides. Acta Crystallogr. A32, 751-767.

Sigmarsson, O., Carn, S., Carracedo, J.C., 1998. Systematics of U-series nuclides in primitive lavas from the 1730-36 eruption on Lanzarote, Canary Islands, and implications for the role of garnet pyroxenites during oceanic basalt formations. Earth Planet. Sci. Lett. 162, 137-151.

Sims, K.W.W., Hart, S.R., 2006. Comparison of Th, Sr, Nd and Pb isotopes in oceanic basalts: Implications for mantle heterogeneity and magma genesis. Earth Planet. Sci. Lett. 245, 743-761.

Sims, K.W.W., DePaolo, D.J., Murrell, M.T., Baldridge, W.S., Goldstein, S.J., Clague, D.A., 1995. Mechanisms of magma generation beneath Hawaii and mid-ocean ridges: Uranium/ thorium and samarium/neodymium isotopic evidence. Science 267, 508-512.

Sims, K.W.W., DePaolo, D.J., Murrell, M.T., Baldridge, W.S., Goldstein, S., Clague, D., Jull, M., 1999. Porosity of the melting zone and variations in the solid mantle upwelling rate beneath Hawaii: Inferences from ${ }^{238} \mathrm{U}-{ }^{230} \mathrm{Th}-{ }^{226} \mathrm{Ra}$ and ${ }^{235} \mathrm{U}-{ }^{231} \mathrm{~Pa}$ disequilibria. Geochim. Cosmochim. Acta 63, 4119-4138.

Sims, K.W.W., Goldstein, S.J., Blichert-Toft, J., Perfit, M.R., Kelemen, P., Fornari, D.J., Michael, P., Murrell, M.T., Hart, S.R., DePaolo, D.J.,
Layne, G., Ball, L., Jull, M., Bender, J., 2002. Chemical and isotopic constraints on the generation and transport of magma beneath the East Pacific Rise. Geochim. Cosmochim. Acta 66, 3481-3504.

Sims, K.W.W., Hart, S.R., Reagan, M.K., Blusztajn, J., Staudigel, H., Sohn, R.A., Layne, G.D., Ball, L.A., Andrews, J., in press. ${ }^{238} \mathrm{U}-{ }^{230} \mathrm{Th}-{ }^{226} \mathrm{Ra}-{ }^{210} \mathrm{~Pb}-{ }^{210} \mathrm{Po},{ }^{232} \mathrm{Th}-{ }^{228} \mathrm{Ra}$ and ${ }^{235} \mathrm{U}-{ }^{231} \mathrm{~Pa}$ constraints on the ages and petrogenesis of Vailulu'u and Malumalu Lavas, Samoa. Geochem. Geophys. Geosyst.

Sobolev, A.V., 2000. Recycled oceanic crust observed in 'ghost plagioclase' within the source of Mauna Loa lavas. Nature 404, 986-990.

Spiegelman, M., Elliott, T., 1993. Consequences of melt transport for U-series disequilibrium in young lavas. Earth Planet. Sci. Lett. $118,1-20$.

Stracke, A., Salters, V.J.M., Sims, K.W.W., 1999. Assessing the presence of garnet-pyroxenite in the mantle sources of basalts through combined hafnium-neodymium-thorium isotope systematics. Geochem. Geophys. Geosyst. 1.

Turner, S.P., Hawkesworth, C., Rogers, N., King, P., 1997. U-Th isotope disequilibria and ocean island basalt generation in the Azores. Chem. Geol. 139.

Ulmer, P., Luth, R.W., 1991. The graphite-COH fluid equilibrium in P, T, fO2 space. Contrib. Mineral. Petrol. 106, 265-272.

van Westrenen, W., Blundy, J.D., Wood, B.J., 1999. Crystal-chemical controls on trace element partitioning between garnet and anhydrous silicate melt. Am. Mineral. 84, 838-847.

van Westrenen, W., Blundy, J.D., Wood, B.J., 2000. Effect of $\mathrm{Fe}^{2+}$ on garnet-melt trace element partitioning: Experiments in FCMAS and quantification of crystal-chemical controls in natural systems. Lithos 53, 189-201.

van Westrenen, W., Wood, B.J., Blundy, J.D., 2001. A predictive thermodynamic model of garnet-melt trace element partitioning. Contrib. Mineral. Petrol. 142, 219-234.

Widom, W., Carlson, R.W., Gill, J.B., Schmincke, H.U., 1997. Th-Sr$\mathrm{Nd}-\mathrm{Pb}$ isotope and trace element evidence for the origin of the Sao Miguel enriched mantle source. Chem. Geol. 140, 49-68.

Wood, B.J., Blundy, J.D., 1997. A predictive model for rare earth element partitioning between clinopyroxene and anhydrous silicate melt. Contrib. Mineral. Petrol. 129, 166-181.

Wood, B.J., Blundy, J.D., Robinson, J.A.C., 1999. The role of clinopyroxene in generating U-series disequilibrium during mantle melting. Geochim. Cosmochim. Acta 63, 1613-1620.

Workman, R.K., Hart, S.R., 2005. Major and trace element composition of the depleted MORB mantle (DMM). Earth Planet. Sci. Lett. 231, 53-72.

Workman, R.K., Hart, S.R., Jackson, M., Regelous, M., Farley, K.A., Blusztajn, J., Kurz, M., Staudigel, H., 2004. Recycled metasomatized lithosphere as the origin of the Enriched Mantle II (EM2) end-member: evidence from the Samoan Volcanic Chain. Geochem. Geophys. Geosyst. 5.

Workman, R.K., Hauri, E., Hart, S.R., Wang, J., Blusztajn, J., 2006. Volatile and trace elements in basaltic glasses from Samoa: implications for water distribution in the mantle. Earth Planet. Sci. Lett. 241, 932-951.

Zindler, A., Hart, S., 1986. Chemical geodynamics. Annual reviews in earth and planetary. Science 11, 493-571. 


\title{
CHAPTER 3:
}

\section{MELT GENERATION AND MAGMA TRANSPORT RATES BENEATH THE

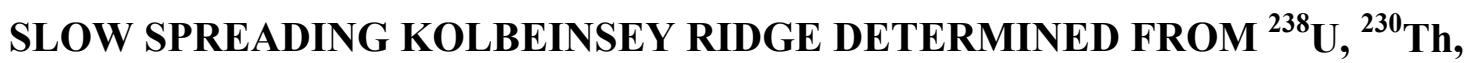 AND ${ }^{231}$ Pa EXCESSES}

\begin{abstract}
Here we report measurements of $\mathrm{U}-\mathrm{Th}-\mathrm{Pa}-\mathrm{Ra}$ disequilibria, $\mathrm{Hf}, \mathrm{Sr}, \mathrm{Nd}$, and $\mathrm{Pb}$ isotopes, and trace-element compositions for 33 young $(<10 \mathrm{ka})$ mid-ocean ridge basalts $(\mathrm{MORB})$ from the slow-spreading Kolbeinsey Ridge north of Iceland (half-spreading rate $=\sim 0.9$ $\mathrm{cm} / \mathrm{yr}$.; $\left.67^{\circ} 05^{\prime}-70^{\circ} 26^{\prime} \mathrm{N}\right)$. The remaining basalts display both $\left({ }^{230} \mathrm{Th} /{ }^{238} \mathrm{U}\right)<1$ and $\left({ }^{230} \mathrm{Th} /{ }^{238} \mathrm{U}\right)>1$, with $\left({ }^{230} \mathrm{Th} /{ }^{238} \mathrm{U}\right)$ ranging from 0.95 to 1.30 . These are some of the most $\mathrm{U}$ (as low as $11 \mathrm{ppb}$ ) and Th (as low as $35 \mathrm{ppb}$ ) depleted samples yet studied. With the exception of the four northernmost Kolbeinsey samples, which display unique, enriched radiogenic isotope signatures characteristic of the region near the Jan Mayen Fracture Zone (e.g. mean $\varepsilon_{\mathrm{Nd}}=+8.0$ near Jan Mayen vs. +9.7 along the rest of the ridge), Kolbeinsey Ridge samples lie in a narrow range of $\left({ }^{230} \mathrm{Th} /{ }^{232} \mathrm{Th}\right)(1.20-1.32)$ with a correspondingly large range in $\left({ }^{238} \mathrm{U} /{ }^{232} \mathrm{Th}\right)(0.94$ to 1.32$)$. Thus, these data lie on a horizontal array on a $\left({ }^{230} \mathrm{Th} /{ }^{232} \mathrm{Th}\right)$ vs. $\left({ }^{238} \mathrm{U} /{ }^{232} \mathrm{Th}\right)$ equiline diagram. However, Kolbeinsey Ridge $\mathrm{Nd}, \mathrm{Sr}, \mathrm{Hf}$, and $\mathrm{Pb}$ isotopic compositions are relatively depleted and show a limited range (e.g. $\varepsilon_{\mathrm{Nd}}=+8.4-+10.5,{ }^{87} \mathrm{Sr} /{ }^{86} \mathrm{Sr}=0.70272-0.70301, \varepsilon_{\mathrm{Hf}}=+15.4-$ +19.6 , and $\left.{ }^{208} \mathrm{~Pb} /{ }^{206} \mathrm{~Pb}=2.043-2.095\right)$. Based on $\left({ }^{234} \mathrm{U} /{ }^{238} \mathrm{U}\right)$ ratios $>1.005$, we exclude 12 of the samples because of potential post-depositional contamination by chemical interaction with seawater. Our measurements show that samples with low $\left({ }^{230} \mathrm{Th} /{ }^{238} \mathrm{U}\right)$ have high $\left({ }^{234} \mathrm{U} /{ }^{238} \mathrm{U}\right)$, whereas Kolbeinsey MORB with $\left({ }^{234} \mathrm{U} /{ }^{238} \mathrm{U}\right)$ of unity have universally high $\left({ }^{230} \mathrm{Th} /{ }^{238} \mathrm{U}\right)$. These high $\left({ }^{230} \mathrm{Th} /{ }^{238} \mathrm{U}\right)$ values can be generated in a long melting column that initiates well within the garnet peridotite stability zone, producing
\end{abstract}


large ${ }^{230} \mathrm{Th}$ excesses in the melts and thick crust. Kolbeinsey lavas are almost uniformly depleted in incompatible trace element abundances and ratios (e.g. average $(\mathrm{La} / \mathrm{Yb})_{\mathrm{n}}=$ 0.41 ), and combined isotopic and trace element systematics (i.e. $\alpha_{\mathrm{Sm}-\mathrm{Nd}}>1$ for most of the Kolbeinsey lavas indicates that their source $\mathrm{Sm} / \mathrm{Nd}$ is younger than the assumed average mantle $1.8 \mathrm{Ga}$ model age) suggest a relatively young, depleted source. 


\subsection{INTRODUCTION}

Uranium series isotopes measured in mid-ocean ridge basalts (MORB) record the effects of melt production and magma transport rates in the upper mantle and lower crust. The half-lives of ${ }^{230} \mathrm{Th}\left(75 \mathrm{kyr}\right.$.), ${ }^{231} \mathrm{~Pa}\left(32.5 \mathrm{kyr}\right.$.), and ${ }^{226} \mathrm{Ra}$ (1600 yr.) are particularly relevant to the time-scales involved with melt generation and transport, so the ${ }^{238} \mathrm{U}^{230} \mathrm{Th}$, ${ }^{230} \mathrm{Th}^{-226} \mathrm{Ra},{ }^{235} \mathrm{U}_{-}{ }^{231} \mathrm{~Pa}$ systems can help constrain the timescales of melting processes such as solid mantle upwelling rates, melt dispersivity, and melt-rock reaction. The ${ }^{238} \mathrm{U}_{-}{ }^{230} \mathrm{Th}$ system is particularly sensitive to source mineralogy: experimentally measured mineral/melt partition coefficients indicate that $\left({ }^{230} \mathrm{Th} /{ }^{238} \mathrm{U}\right)>1$ requires melts to be extracted either from deep, garnet (Gt) bearing lithologies, or possibly spinel peridotites containing clinopyroxene (Cpx) with M2 site radii smaller than 1.0 Å (ELKINS et al., 2008). Such Cpx, however, are unable to produce the large ${ }^{230} \mathrm{Th}$ excesses frequently observed in MORB, and they tend to occur naturally as deep, aluminous $\mathrm{Cpx} .\left({ }^{230} \mathrm{Th} /{ }^{238} \mathrm{U}\right)$ $<1$ indicates shallow spinel peridotite melting (BEattie, 1993a; BeAtTIE, 1993b; ElKins et al., 2008; HAuri et al., 1994; LA TOURETTE and BurnetT, 1992; LA TOURETTE et al., 1993; LANDWEHR et al., 2001; LUNDSTROM et al., 1994; SALTERS and LONGHI, 1999; SALTERS et al., 2002; WoOD et al., 1999).

There have been few systematic geochemical studies of ridge segments that have included complete major element, trace element, long-lived radiogenic isotopes, and Useries data sets. There is such a data set for the Reykjanes Ridge south of Iceland (MurTon et al., 2002; PEATE et al., 2001), but it lacks detailed geographic coverage. The data that now exist for $9-10^{\circ} \mathrm{N}$ on the East Pacific Rise (EPR) are currently the most detailed complete geochemical study of this type (SImS et al., 2003; Sims et al., 2002).

The EPR, however, is a fast-spreading ridge, such that it represents only one endmember of the global spreading ridge system. There are not yet data of this kind of detail for slow-spreading mid-ocean ridges (MOR). Such data are critical to test models for melt generation. Furthermore, because very few MORB suites measured for $\mathrm{U}$-series disequilibria have also been measured for $\mathrm{Hf}, \mathrm{Nd}, \mathrm{Sr}$, and $\mathrm{Pb}$ isotopic compositions, the 
extent to which U-series disequilibria reflect variations in the melting process, as opposed to variable mixing of melts from depleted and enriched mantle sources, is not well constrained.

Here we present a detailed study of the slow-spreading Kolbeinsey ridge, to better understand the differences between melting processes at variable spreading rates. We present measurements of U-Th disequilibria in a suite of 33 samples from the shallow (mean depth $\sim 1100 \mathrm{~km}$ ), slow-spreading (half spreading rate $\sim 0.9 \mathrm{~cm} / \mathrm{yr}$.; (MosAR et al., 2002)) Kolbeinsey Ridge. Many of the samples analyzed have been previously characterized for $\mathrm{Nd}, \mathrm{Sr}, \mathrm{Pb}$, and $\mathrm{Hf}$ isotopes and major and trace element compositions (ANDres et al., 2004; Blichert-TofT et al., 2005; DEVEy et al., 1994; HAASE et al., 2003; Hanan et al., 2000; Mertz et al., 1991; Mertz and HaAse, 1997; Michael, 1995; Michael et al., 1989; NEUMANN and SCHILLing, 1984; SCHILling et al., 1999; SCHILling et al., 1983; SigurdSSON, 1981; WAGGONER, 1989). For samples whose major and trace-element abundances and $\mathrm{Nd}, \mathrm{Sr}, \mathrm{Hf}$, and $\mathrm{Pb}$ isotopic compositions have not previously determined or published, we have also measured these abundances and isotopes. With our combined U-series, major and trace element, and radiogenic isotope data, we investigate melt generation and transport processes beneath this very shallow ridge. We test a suite of melting models to assess the extent to which U-series disequilibria and other trace element fractionations are controlled by spreading rate and contrasting melting behavior of heterogeneous sources. We find that Kolbeinsey Ridge lavas have universally high ${ }^{230} \mathrm{Th}$ excesses, indicating a long, deep melting column exists beneath the ridge.

\subsection{BACKGROUND}

\subsubsection{Geological Setting}

The Kolbeinsey Ridge is a shallow, slow-spreading ridge extending northward from the northern coast of Iceland at $66.5^{\circ} \mathrm{N}$ to the Jan Mayen Fracture Zone (FZ) at 
$71^{\circ} \mathrm{N}$ (Figure 1). The ridge is offset from the northeast Iceland volcanic province (i.e.

a

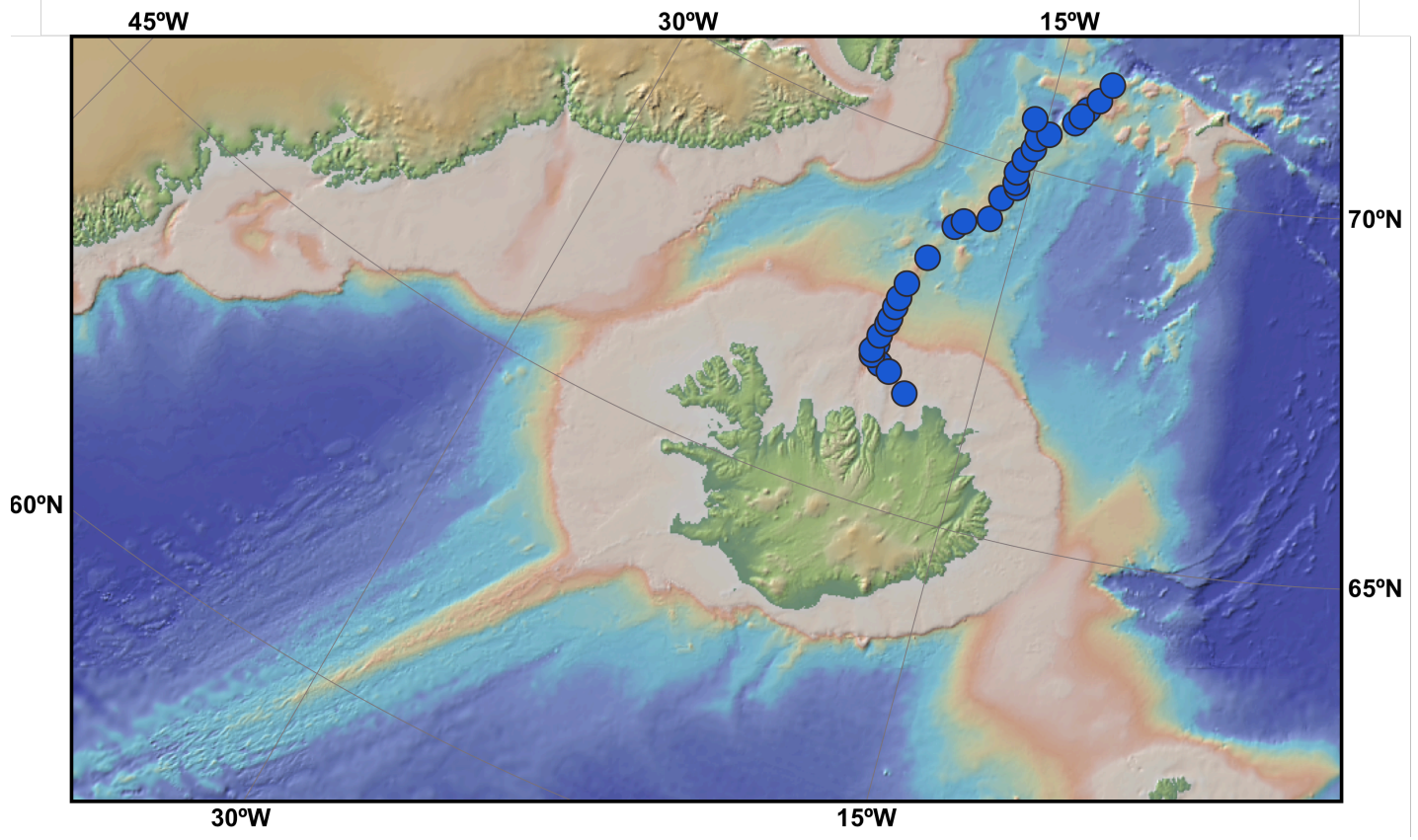

b

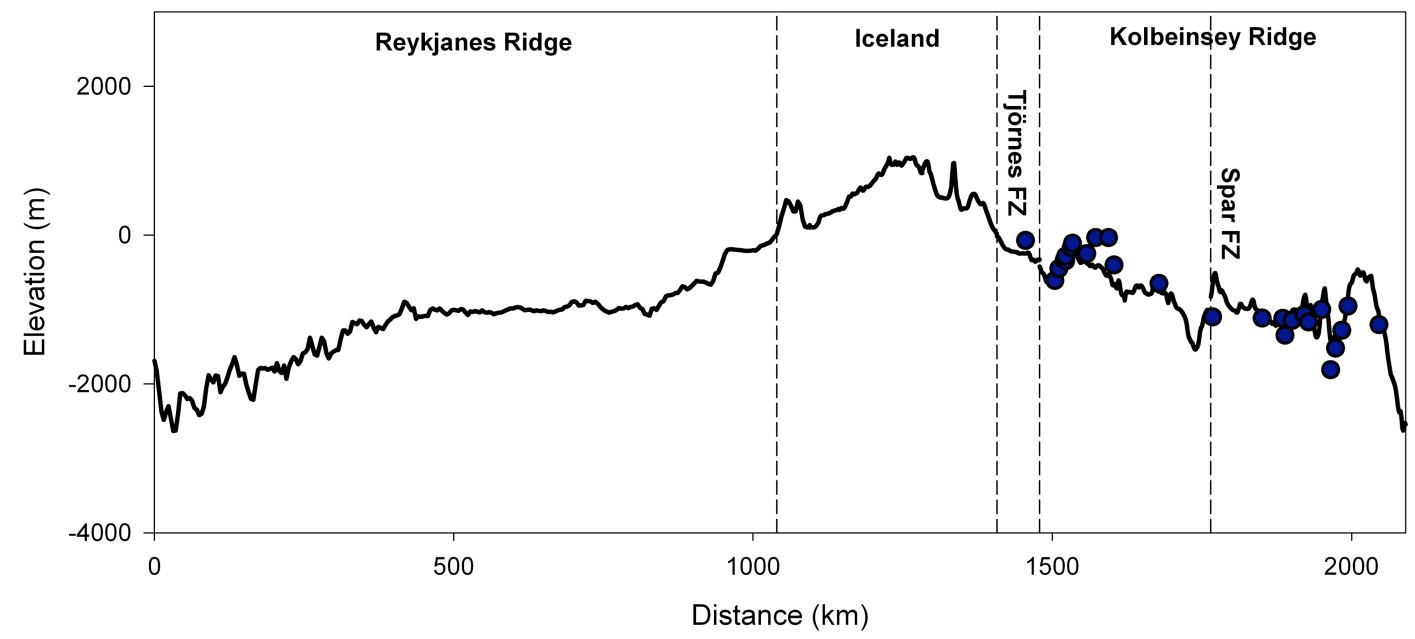

Figure 1. (a) Map of the field area, showing the locations of all samples examined in this study, with bathymetry from Smith and Sandwell (1997) and Jakobsson et al. (2008). (b) A depth profile for the Reykjanes Ridge, Iceland, and the Kolbeinsey Ridge, with Kolbeinsey Ridge sample locations as bold blue circles. 
Krafla, Theistareikjir-Bunga) by the Tjörnes FZ, and broken into two major segments delineated by an overlapping spreading center. The southern segment extends from the Tjörnes FZ to the Spar FZ at $69^{\circ} \mathrm{N}$; the northern segment extends from the Spar FZ to the Jan Mayen FZ. The northern Kolbeinsey Ridge segment is additionally offset by a minor overlapping spreading center located at $70^{\circ} 30^{\prime} \mathrm{N}$ (HAASE et al., 2003); the ridge segment north of this small fracture zone is alternately referred to as the Eggvin Bank (BRANDSDOTTIR et al., 2004; HoOFT et al., 2006).

Given the high sedimentation rate of the North Atlantic, the abundance of fresh glasses dredged from the ridge axis suggests that it is presently active along most of its length (DEvEY et al., 1994). The Kolbeinsey Ridge is one of the shallowest MOR ridges and has an average depth of $1100 \mathrm{~m}$ (compared to $2500 \mathrm{~m}$ for the East Pacific Rise; Figure 1b). The ridge deepens northward from Iceland $(\sim 200 \mathrm{~m})$ until it reaches its maximum depth $\left(\sim 1500 \mathrm{~m}\right.$ at $69^{\circ} \mathrm{N}$, just south of the Spar FZ). North of the Spar FZ the central ridge shallows until it reaches the Eggvin bank, which is in places only $40 \mathrm{~m}$ below sea level. Seismic studies (KoDAIRA et al., 1997; MJELDE et al., 2008)) have shown that the Kolbeinsey Ridge crustal section is 7-10 km thick, notably thicker than the EPR (ca. 6-7 km).

The geographic coverage of the sample suite analyzed in this study encompasses the entire Kolbeinsey Ridge, including the Tjörnes FZ and Eggvin Bank (Figure 1, Table 1). These samples were collected by dredging on a number of research cruises funded by the German Research Ministry, BMFT (F.S. Polarstern cruise ARK V/Ib, 1988; F.S. Polarstern cruise ARK VII/1, 1990; F.S. Poseidon cruise 185, 1991; F.S. Poseidon cruise 210/1 , 1995; F.S. Poseidon cruise 221 , 1996; F.S. Poseidon cruise 229; F.S. Poseidon cruise 291, 2002; F.S. Poseidon cruise 326, 2005), and the R/V Trident leg 139 (1971).

\subsubsection{Age Constraints}

During the last glacial period ( 10 ka), high latitude regions, including Iceland and the Kolbeinsey Ridge, were covered with ice. Shallower parts of the Kolbeinsey 
Ridge (e.g. the northern part of the Eggvin Bank) were above sea level, which has risen $\sim 121 \mathrm{~m}$ since the last glacial maximum (FAIRBANKS, 1989). Extensive glacial outwash during subsequent deglaciation covered the ocean floor with a thick veneer of glacial debris; this sediment layer thickens towards Iceland. Sedimentation rates have been significant enough that in areas with volcanic morphological features visible in bathymetric profiles, some sampling efforts have only retrieved sediment and ice-rafted glacial debris, suggesting the volcanic features in those areas predate glaciation (BAUMANN et al., 1993; HoOFT et al., 2006; LACKSCHEwITZ et al., 1994). Although recent seismic surveys have not allowed for direct measurement of sediment thickness on the Kolbeinsey Ridge, the extensive sediment deposited in basins near Iceland indicates sedimentation has been significant. Measurements of sediment thicknesses in pull-apart basins along the Tjörnes FZ range from at least $100 \mathrm{~m}$ for the small Grimsey Graben (V. Dekov, pers. communication) to up to $4 \mathrm{~km}$ in the $700 \mathrm{~m}$ deep Eyjafjarðarall basin, the southernmost expression of the Kolbeinsey Ridge (HoofT et al., 2006).

Post-glacial volcanism ( $<10 \mathrm{ka}$ ) along the ridge axis has 'punched through' this outwash and produced a distinct neovolcanic zone. This is well illustrated in a highresolution multi-beam bathymetry of the Tjörnes FZ and Southern Kolbeinsey Ridge (BRANDSDOTTIR et al., 2004; HoOFT et al., 2006), which shows features such as moraines and glacial sediment covering the ocean floor, with a well-developed neovolcanic zone in the center of the ridge. Interpretation of U-Th and U-Pa disequilibria in terms of magmatic processes requires the age of the samples to be much less than the half-life of ${ }^{230} \mathrm{Th}$ (75 kyr.) and ${ }^{231} \mathrm{~Pa}$ (32.5 kyr.). That cruise dredges recovered basaltic glass, rather than glacial outwash, constrains the ages of our samples to younger than $10 \mathrm{ka}$, which is within the uncertainty of $\left({ }^{230} \mathrm{Th} /{ }^{238} \mathrm{U}\right)$ measurements $(\sim 1 \%)$.

We derive additional confirmation of our young lavas from sample POS210/1 702DS-1, for which we measured $\left({ }^{226} \mathrm{Ra} /{ }^{230} \mathrm{Th}\right)=1.10 \pm 3 \%$ (Table 2$) .{ }^{226} \mathrm{Ra}$ has a halflife of 1600 years, so $\left({ }^{226} \mathrm{Ra} /{ }^{230} \mathrm{Th}\right)>1$ indicates that the sample must be younger than 8 ka. Thus even our deepest sample (dredged from $1520 \mathrm{~m}$ depth) is younger than the last glacial maximum. 


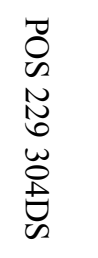
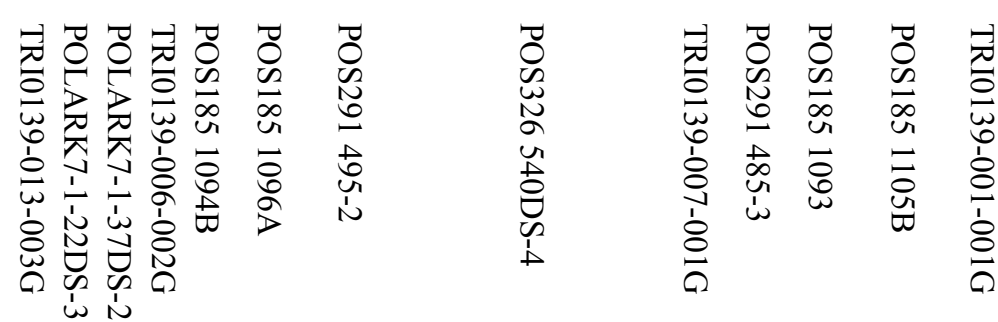

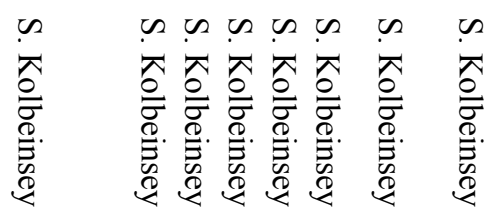

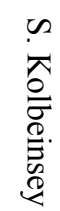

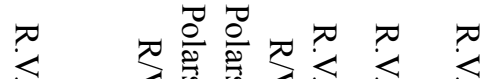

०

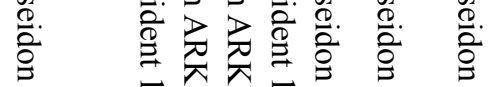

N

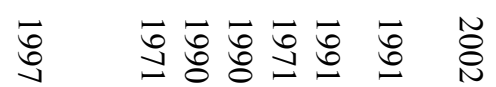

जे जे जे ने बे

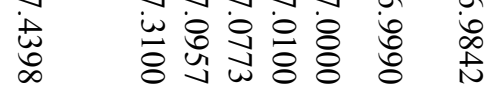

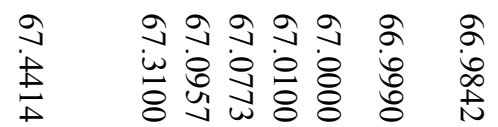

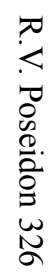

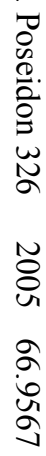

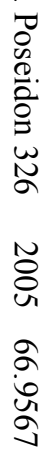

$\dot{\infty} \quad \dot{\infty} \dot{\infty} \frac{1}{\infty} \dot{\infty} \frac{1}{\infty}$

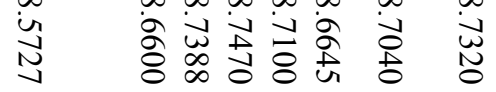

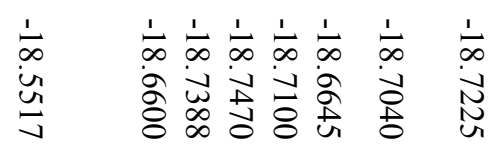

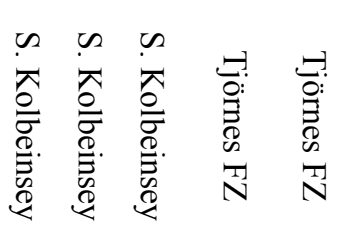

$\mid$

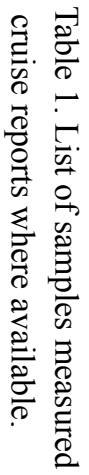

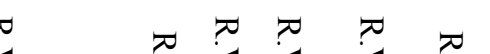

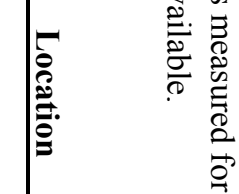

ڤे

a $a$ ลे aे a

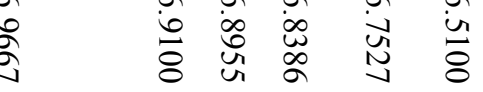

$\dot{\infty} \dot{\infty} \frac{1}{\infty} \doteq$

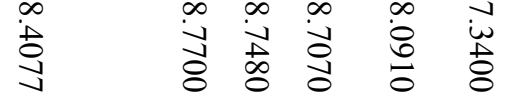

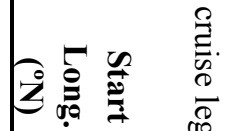

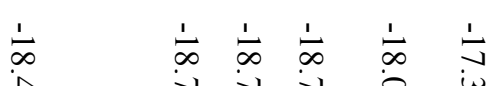

(a)

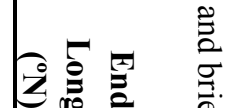

六 ठ

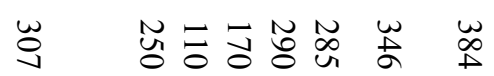

$\omega_{\omega}^{\omega}$

雚

Eิ

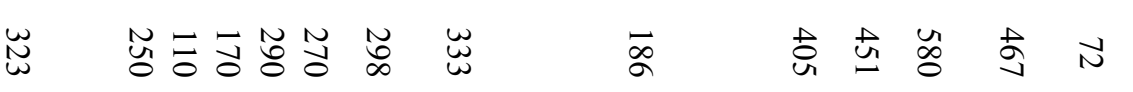

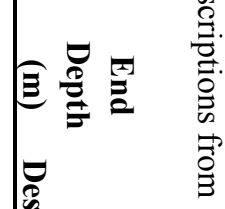

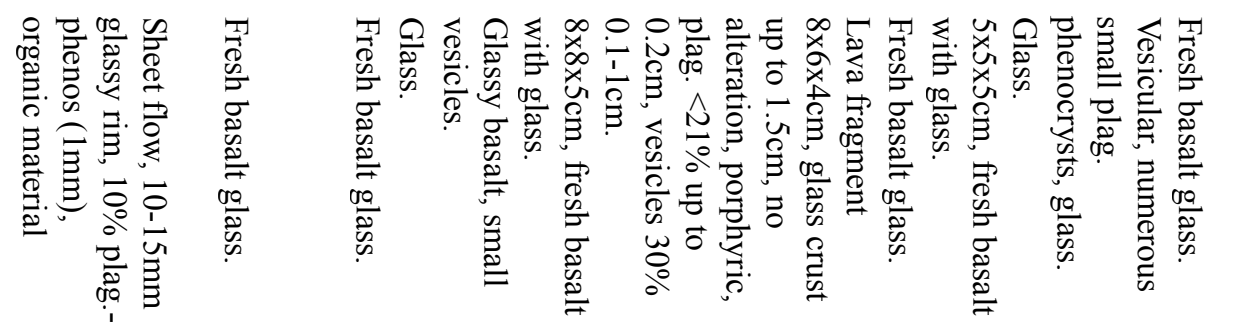




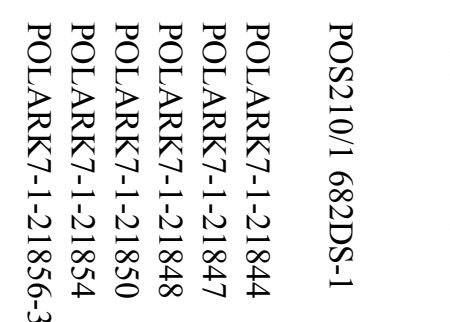

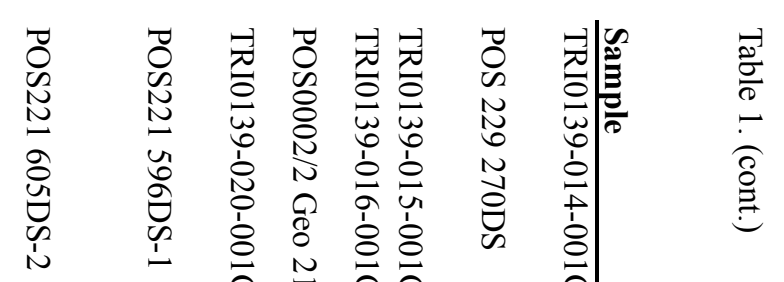

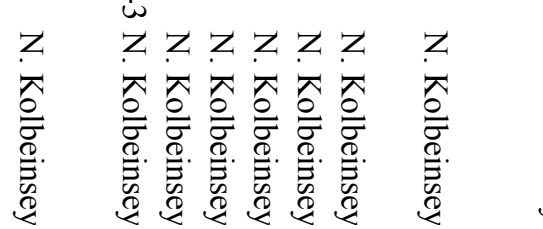

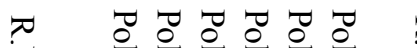

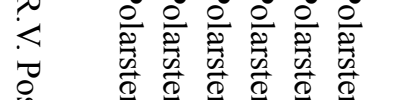

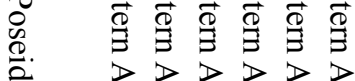

产

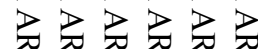

元

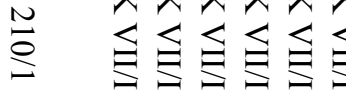

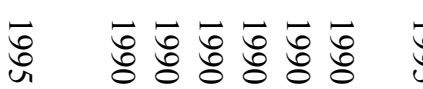

ㄱ. 깅ㅎㅇ

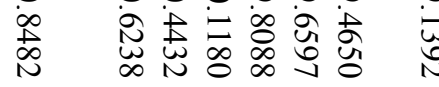

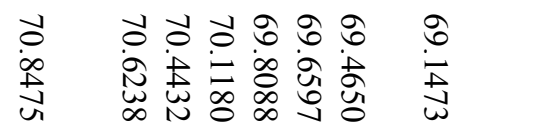

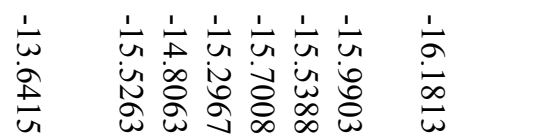

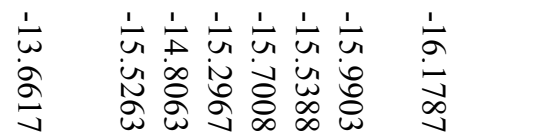

芯

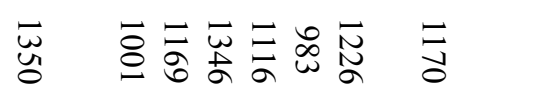
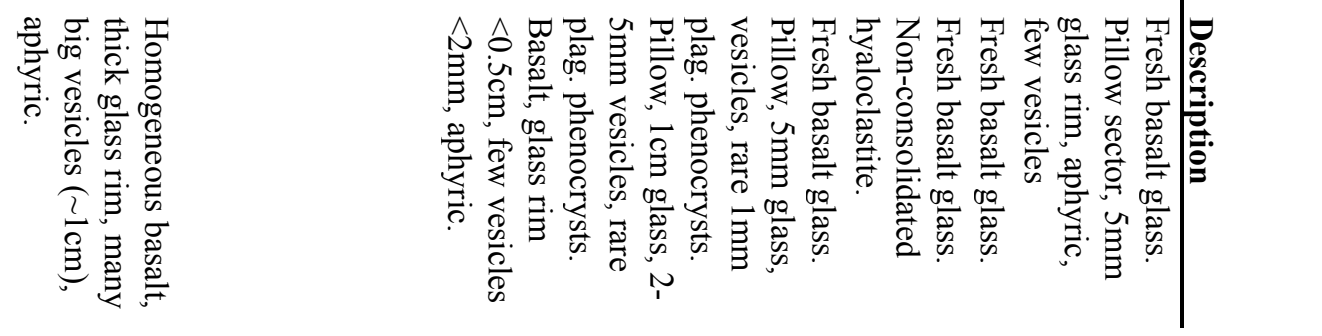


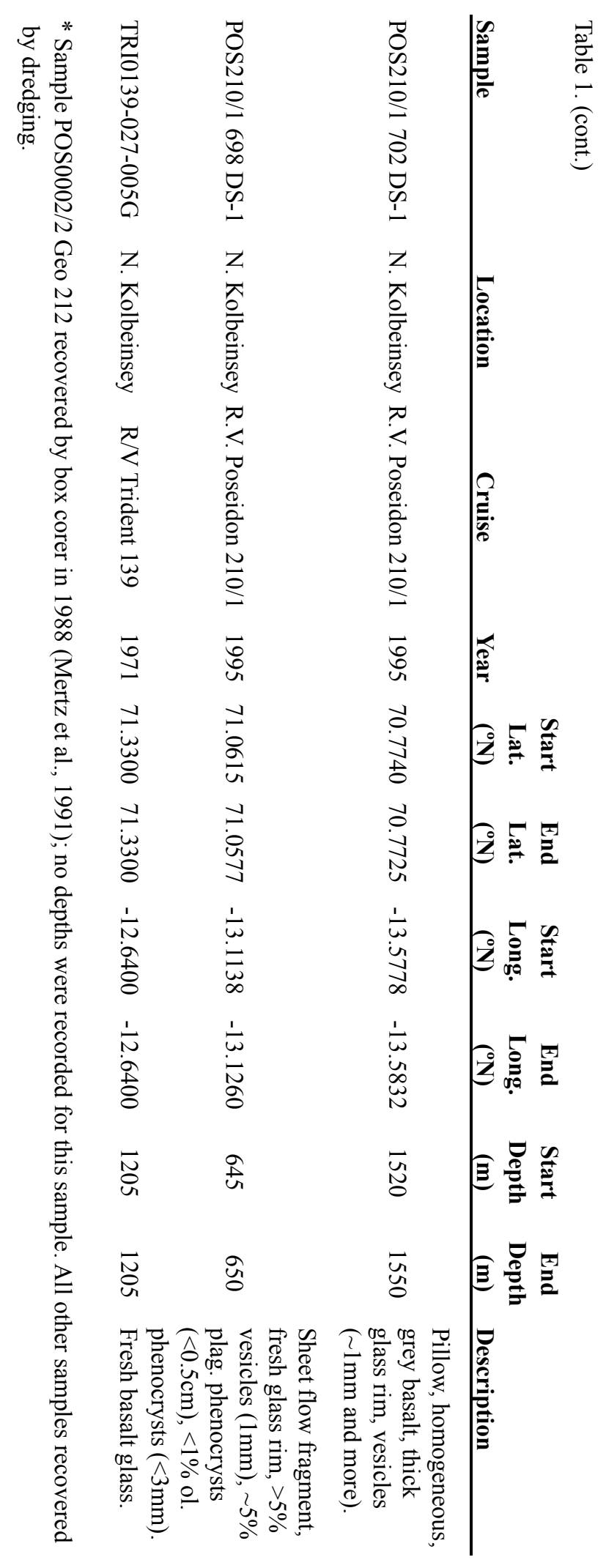




\subsubsection{Chemical and Isotopic Compositions}

Many of the samples analyzed have been previously characterized for their $\mathrm{Nd}$, $\mathrm{Sr}, \mathrm{Pb}$, and $\mathrm{Hf}$ isotopic compositions and major- and trace-element abundances, including isotope dilution measurements of $\mathrm{Rb}, \mathrm{Sr}, \mathrm{Sm}, \mathrm{Nd}, \mathrm{U}, \mathrm{Th}, \mathrm{Pb}, \mathrm{Lu}$, and $\mathrm{Hf}$ (ANDRES et al., 2004; Blichert-Toft et al., 2005; Devey et al., 1994; HAASE et al., 2003; HANAN et al., 2000; MertZ et al., 1991; MertZ and HaAse, 1997; Michael, 1995; Michael et al., 1989; Neumann and Schilling, 1984; Schilling et al., 1999; Schilling et al., 1983; SigURDSSON, 1981; WAGGONER, 1989).

The Kolbeinsey Ridge basalts are mafic quartz tholeiites $(\mathrm{MgO}=6-10$ wt. \%; (DEVEY et al., 1994)). Fractionation-corrected $\mathrm{Na}_{2} \mathrm{O}$ contents $\left(\mathrm{Na}_{8}\right)$ are among the lowest and fractionation corrected $\mathrm{FeO}$ contents $\left(\mathrm{Fe}_{8}\right)$ among the highest found on the global ridge system, indicating these MORB are the result of large degrees of melting and a deep onset of melting (KLEIN and LANGMUIR, 1987). Compared to most other MORB, the Kolbeinsey Ridge basalts are trace-element depleted (e.g. average $(\mathrm{La} / \mathrm{Yb})_{\mathrm{N}}=0.41$, while average MORB $=1.03$ (KELEMEN et al., 2004)).

Figure 2 shows variations in isotopic and trace element geochemical data from the literature and this study, for the Reykjanes Ridge south of Iceland, Icelandic lavas, and the Kolbeinsey Ridge. Isotopic studies by Mertz et al. (1991) and Mertz and Haase (1997) demonstrated small but systematic variations in $\mathrm{Sr}$ and $\mathrm{Nd}$ isotopic compositions along the Kolbeinsey Ridge (e.g. ${ }^{87} \mathrm{Sr} /{ }^{86} \mathrm{Sr}=0.7027-0.7030$ ). Mertz et al. (1991) also found a decrease in trace element ratios (e.g. $\mathrm{U} / \mathrm{Pb}$ ) with approach to Iceland, indicating that the most isotopically enriched samples (i.e. high ${ }^{87} \mathrm{Sr} /{ }^{86} \mathrm{Sr}$, low ${ }^{143} \mathrm{Nd} /{ }^{144} \mathrm{Nd}$ ) have the most depleted chemical signatures. Although $\mathrm{Sr}$ and $\mathrm{Nd}$ isotopes point to a more enriched source as one approaches Iceland, Mertz et al. (1991) argued, based on constant

${ }^{206} \mathrm{~Pb} /{ }^{204} \mathrm{~Pb}$ isotope ratios, that the Iceland plume component is not involved in Kolbeinsey Ridge magmatism. More recently, Schilling et al. (1999) argued otherwise and documented gradients in $\mathrm{He}, \mathrm{Pb}, \mathrm{Sr}$, and $\mathrm{Nd}$ isotopes and trace-element characteristics (e.g. $\mathrm{Th} / \mathrm{U}$ ) across the Tjörnes FZ and southern Kolbeinsey Ridge that they interpret as 

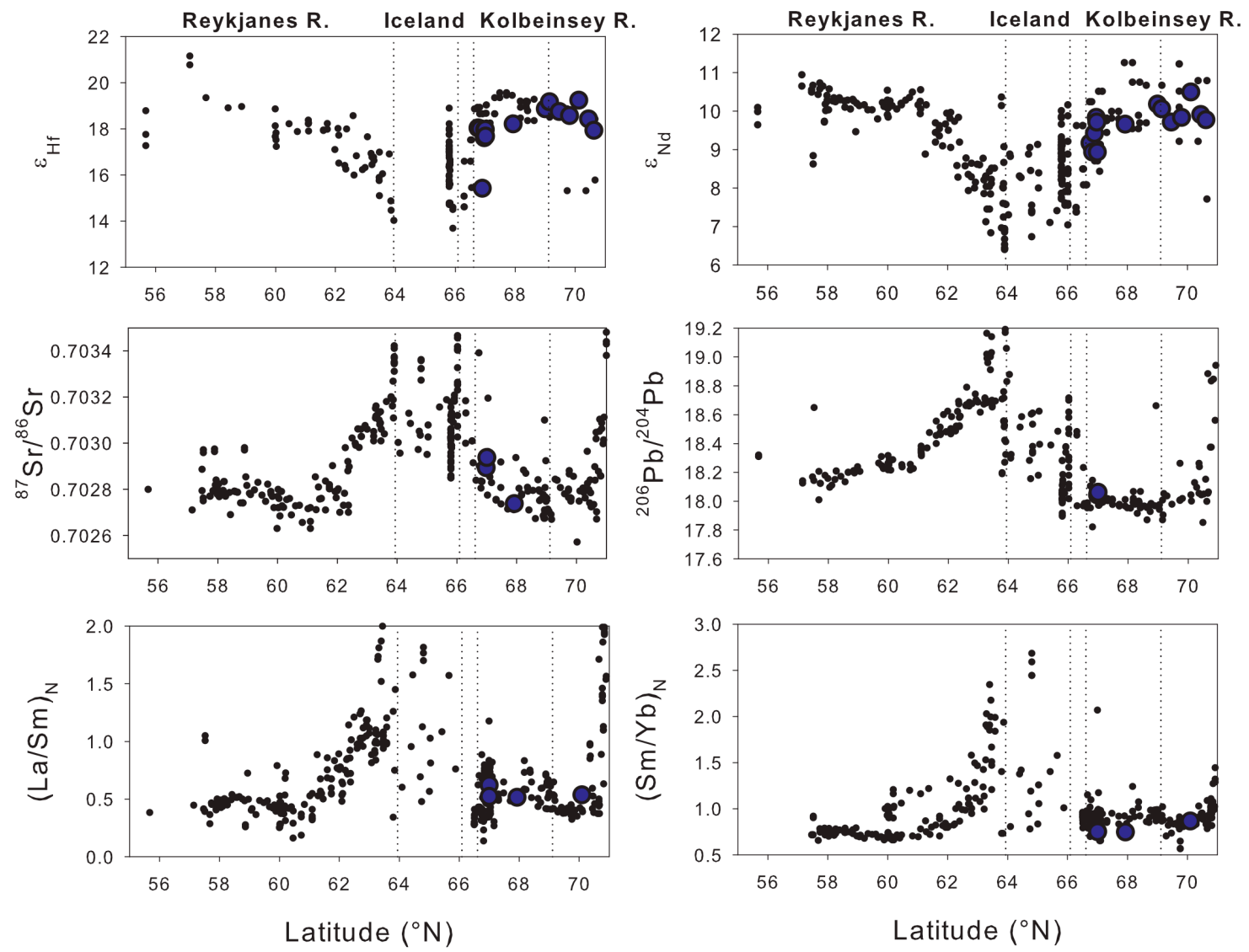

Figure 2. Trace element ratios and long-lived radiogenic isotopic ratios for the Kolbeinsey Ridge, plotted vs. latitude for the Reykjanes Ridge, Iceland, and the Kolbeinsey Ridge. Literature data shown as small black data points (BLICHERT-TOFT et al., 2005; COHEN et al., 1980;

CONDOMINES et al., 1981; DEVEY et al., 1994; DUPRE and ALlEGRE, 1980; FURMAN et al., 1991; HAASE et al., 2003; HANAN et al., 2000; HARDARSON and FITTON, 1997; HARDS et al., 1995; HEMOND et al., 1993; HiLtON et al., 2000; MERTZ et al., 1991; MERTZ and HAASE, 1997; MURTON et al., 2002; NEUMANN and SCHILLING, 1984; O'NIONS and PANKHURS.RJ, 1973; PEATE et al., 2001; POREDA et al., 1986; SALTERS and WHITE, 1998; SCHILLING, 1975; SCHILLING et al., 1999; SCHILLING et al., 1983; STECHER et al., 1999; STRACKE et al., 2006; STRACKE et al., 2003a; STRACKE et al., 2003b; SUN and JAHN, 1975; THIRLWALL et al., 2004), and new data from this study are shown as dark blue circles.

mapping the northward dispersion of the Iceland Plume.

Blichert-Toft et al. (2005) analyzed many of the samples in our data set for highprecision $\mathrm{Pb}$ and $\mathrm{Hf}$ isotope ratios (notably most dredge samples collected on the $\mathrm{R} / \mathrm{V}$ Trident (1971) and R/V Endeavour (1973) cruise legs), providing new insight into the formation of these lavas. Principal component analysis of the ${ }^{206} \mathrm{~Pb} /{ }^{204} \mathrm{~Pb},{ }^{207} \mathrm{~Pb} /{ }^{204} \mathrm{~Pb}$, and 
${ }^{208} \mathrm{~Pb} /{ }^{204} \mathrm{~Pb}$ isotopic variation along this ridge suggested that Kolbeinsey Ridge lavas formed as a result of mixing between a "FOZO"-like component (HART et al., 1992) and a “depleted MORB mantle" (DMM) component (BLICHERT-TOFT et al., 2005).

Kolbeinsey Ridge MORB north of $\sim 70.6^{\circ} \mathrm{N}$ have more enriched radiogenic isotopic compositions than other Kolbeinsey Ridge lavas (MERTZ et al., 2004). Sr, Nd, $\mathrm{Hf}$, and $\mathrm{Pb}$ isotopes reach their most enriched values on the Jan Mayen rise, and then systematically grow less enriched away from the Jan Mayen FZ along the Mohns Ridge to the north. Schilling et al. (1999) and others (e.g. (NEUMANN and ScHILLING, 1984)) suggested that the isotope signatures are the result of a laterally dispersing mantle plume beneath the Jan Mayen region, while others have suggested cool edge effects or trapped subcontinental material in the mantle beneath Jan Mayen (MERTZ et al., 2004; TRONNES et al., 1999).

\subsection{RESULTS}

\subsubsection{U-Series Disequilibria in Kolbeinsey Ridge Basalts}

Uranium-series isotopes were measured by thermal ionization mass spectrometry (TIMS) at Los Alamos National Laboratory (LANL), New Mexico using methods described in Sims et al. (1999a; 1995) and Goldstein et al. (1989) and at Faculteit der Aardenschappen, Vrije Universiteit, Amsterdam using methods described in Frujiter et al. (FrUJiTER et al., 2000), and by Plasma Ionization Multi-collector Mass Spectrometry (PIMMS) at the Woods Hole Oceanographic Institution (WHOI) in Woods Hole, MA (methods as in Sims et al. (2008b) and Ball et al. (2008)), and the University of Bristol in Bristol, UK (methods as described in Hoffman et al. (2007); Regelous et al. (2004), Prytulak et al. (2008), and Sims et al. (2008b)). Neodymium and Hf isotopes were measured by PIMMS at l'École Normale Supérieure (l'ENS) de Lyon (methods as in Blichert-Toft et al. (2001)), and Sr and Pb isotopes were analyzed by PIMMS at WHOI (SIMS and HART, 2006; TARAS and HART, 1987; TODT et al., 1996; White et al., 2000). 
Replicates for $\mathrm{U}$ and $\mathrm{Th}$ concentrations and isotopes between labs were overall in very good agreement, which is consistent with the interlab comparison of standard analyses evaluated in Sims et al. (2008a).

\subsubsection{1. ${ }^{238} U-{ }^{234} U$}

All U-series analysis results are reported in Table 2. We measured $\left({ }^{234} \mathrm{U} /{ }^{238} \mathrm{U}\right)$ wherever possible to evaluate sample contamination. All samples used in this study were handpicked glasses; $\left.{ }^{234} \mathrm{U} /{ }^{238} \mathrm{U}\right)$ measurements were possible for all but a few samples, as shown in Table 2. $\left({ }^{234} \mathrm{U}{ }^{238} \mathrm{U}\right)$ data do not exist for the early data set from Amsterdam, or for a sample that did not run successfully at WHOI.) For submarine basalts, $\left({ }^{234} \mathrm{U} /{ }^{238} \mathrm{U}\right)$ activity ratios are a sensitive indicator of secondary processes such as alteration, as seawater is significantly enriched in ${ }^{234} \mathrm{U}$ relative to ${ }^{238} \mathrm{U}\left(\left({ }^{234} \mathrm{U} /{ }^{238} \mathrm{U}\right)_{\mathrm{sw}}=1.14\right.$; (HENDERSON et al., 1993; Ku et al., 1977; RoBinson et al., 2004)). Although all measured samples are reported in Tables 2 and 3, when evaluating the chemical and isotopic systematics of Kolbeinsey lavas we only considered samples with $\left({ }^{234} \mathrm{U} /{ }^{238} \mathrm{U}\right)$ activity ratios $=1.000 \pm 0.005$, which indicates minimal post-eruption alteration within our analytical detection capabilities. Based on this criterion, we reject 12 samples from further consideration in terms of primary melting processes.

In Figure $3 b$ we show results for $\left({ }^{238} \mathrm{U} /{ }^{232} \mathrm{Th}\right)$ vs. $\left({ }^{230} \mathrm{Th} /{ }^{232} \mathrm{Th}\right)$ in our data set, distinguished based on $\left({ }^{234} \mathrm{U} /{ }^{238} \mathrm{U}\right)$ results $\left(\left({ }^{230} \mathrm{Th} /{ }^{238} \mathrm{U}\right)\right.$ data are presented in more detail below in Section 3.3.1.2). Figure 4a shows $\left({ }^{230} \mathrm{Th} /{ }^{238} \mathrm{U}\right)$ disequilibria for Kolbeinsey rocks plotted against $\left({ }^{234} \mathrm{U} /{ }^{238} \mathrm{U}\right)$, and suggests that there is a systematic relationship between the degree of seawater contamination and measured ${ }^{230} \mathrm{Th}^{238} \mathrm{U}$ disequilibrium.

\subsubsection{2. ${ }^{238} \mathrm{U}_{-}{ }^{230} \mathrm{Th}$}

${ }^{238} \mathrm{U}_{-}{ }^{230} \mathrm{Th}$ results are presented in Table 2, Figure 3, and Figure 5. Many Kolbeinsey Ridge samples have extremely low concentrations of $U$ and Th (Th concentrations as low as $33 \mathrm{ppb}$, and $\mathrm{U}$ concentrations down to $11 \mathrm{ppb}$ ), making even large samples ( $>2$ grams) difficult to analyze by TIMS (because of the low ionization 


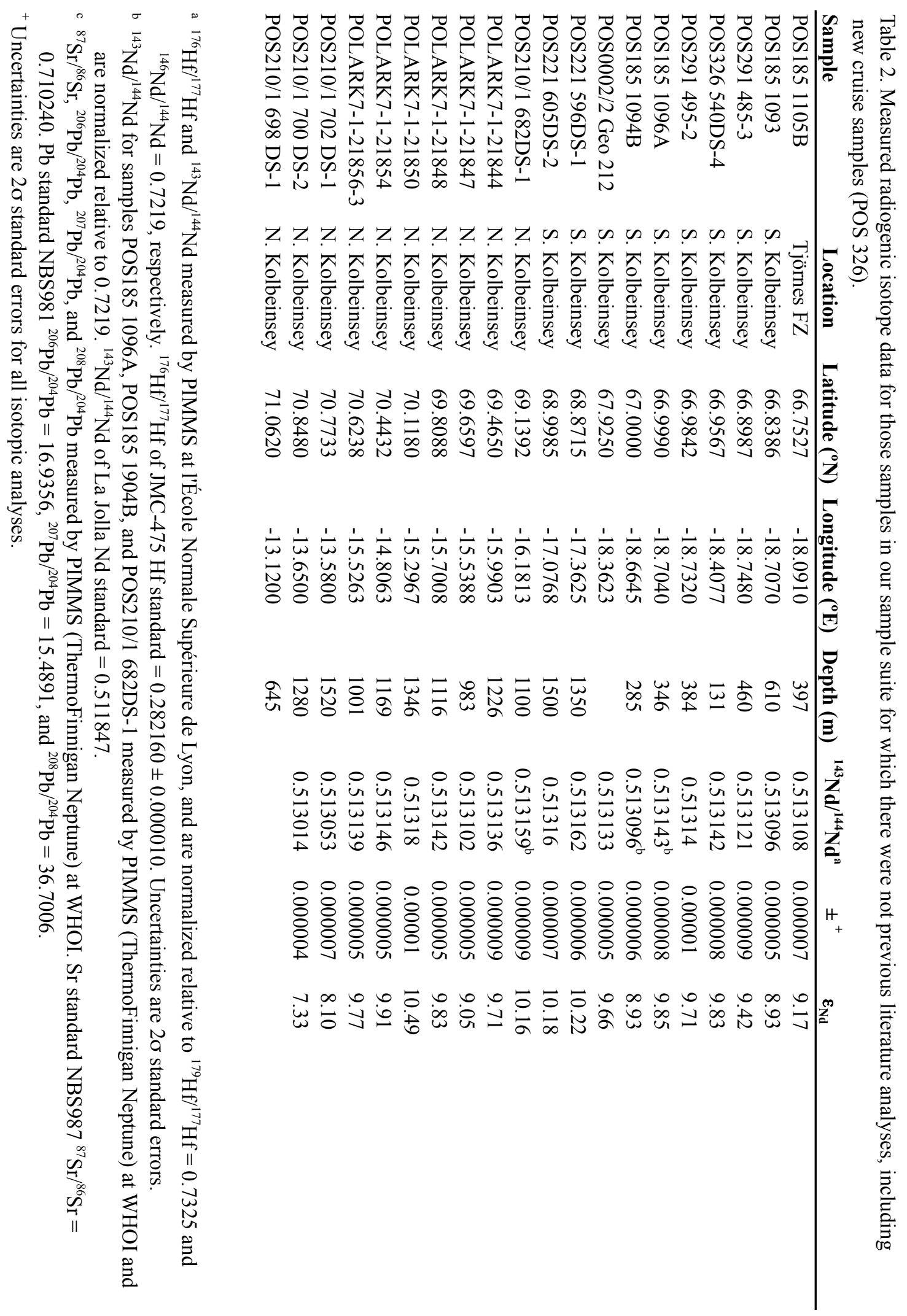




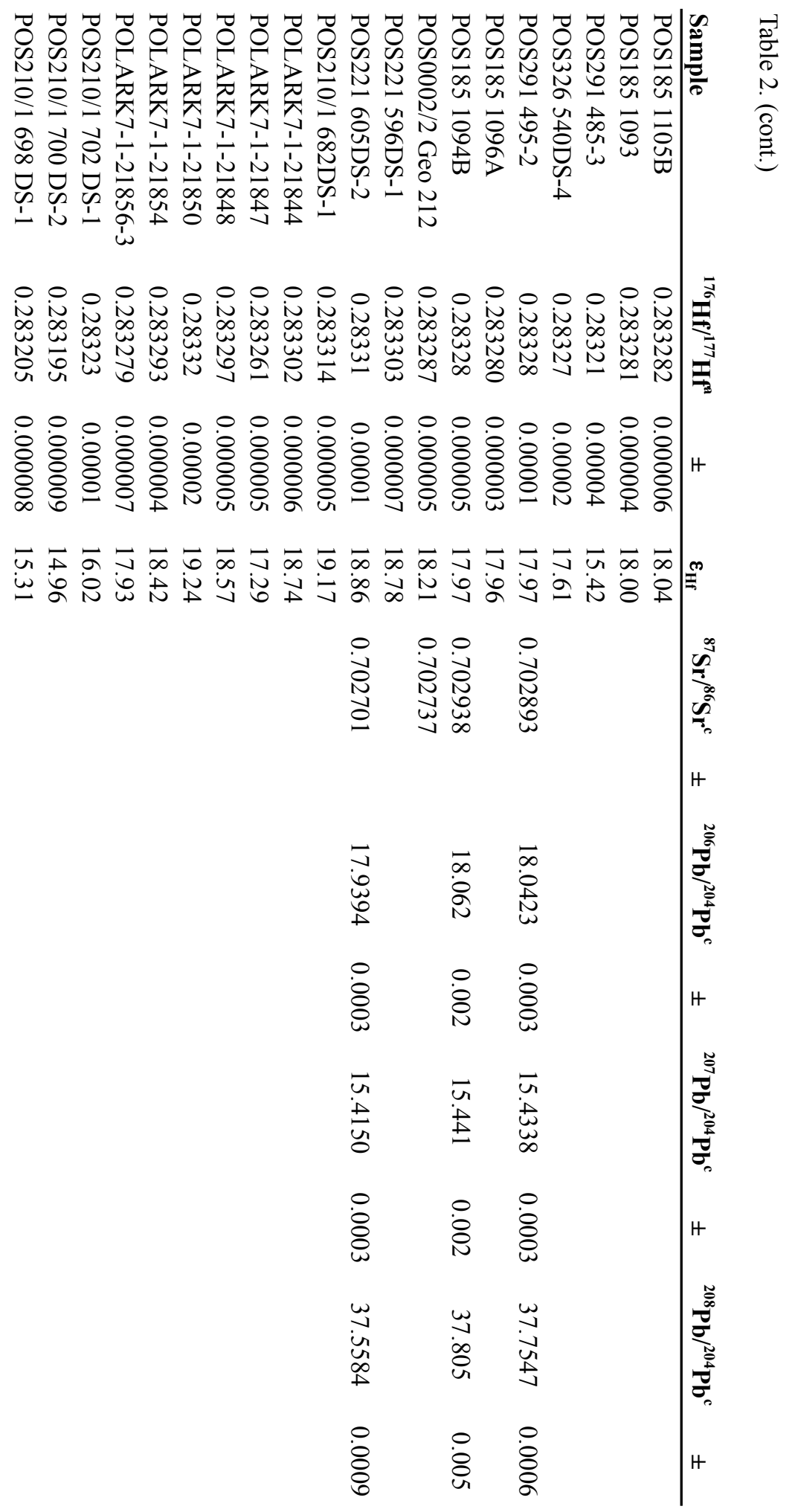




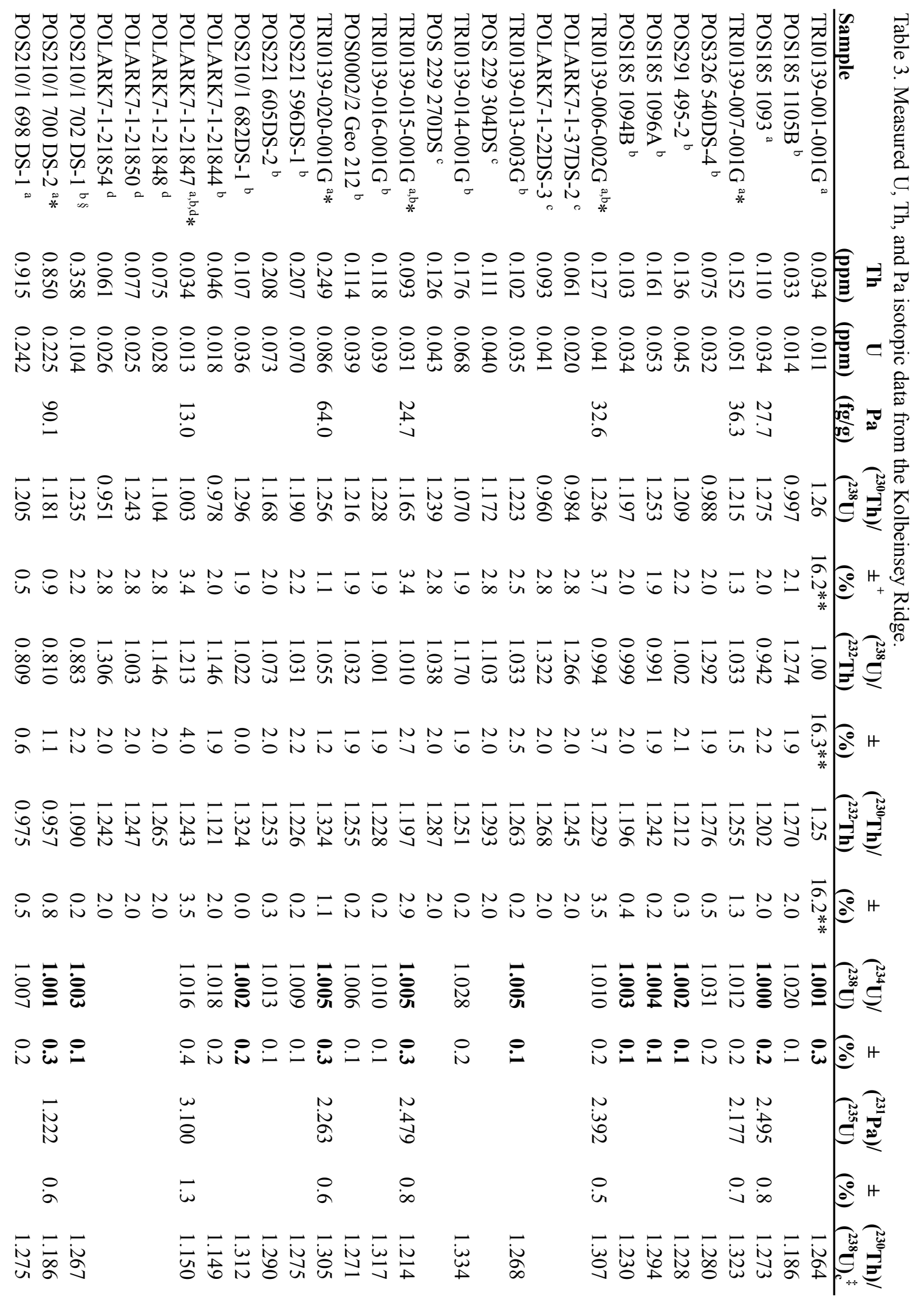




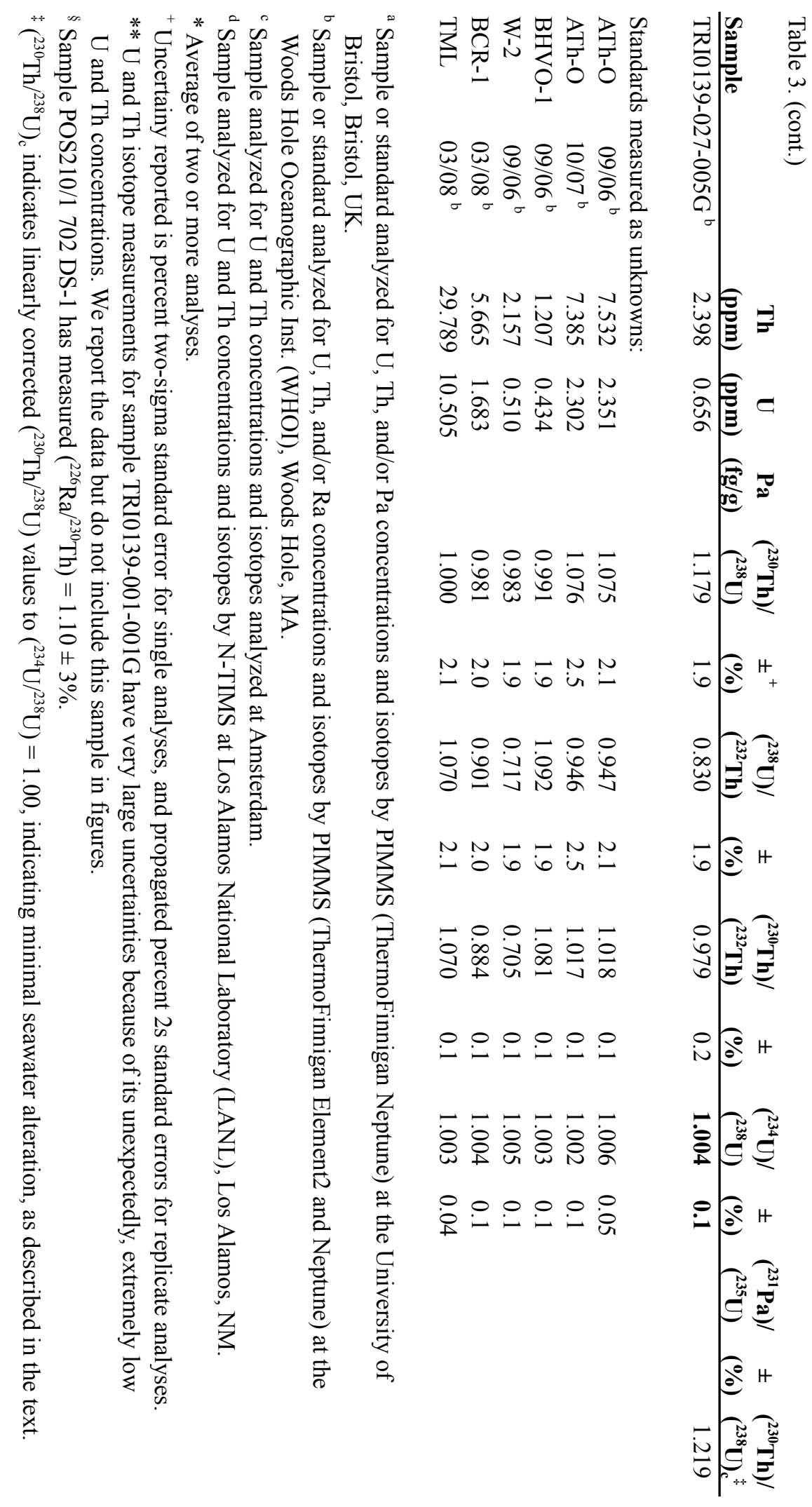




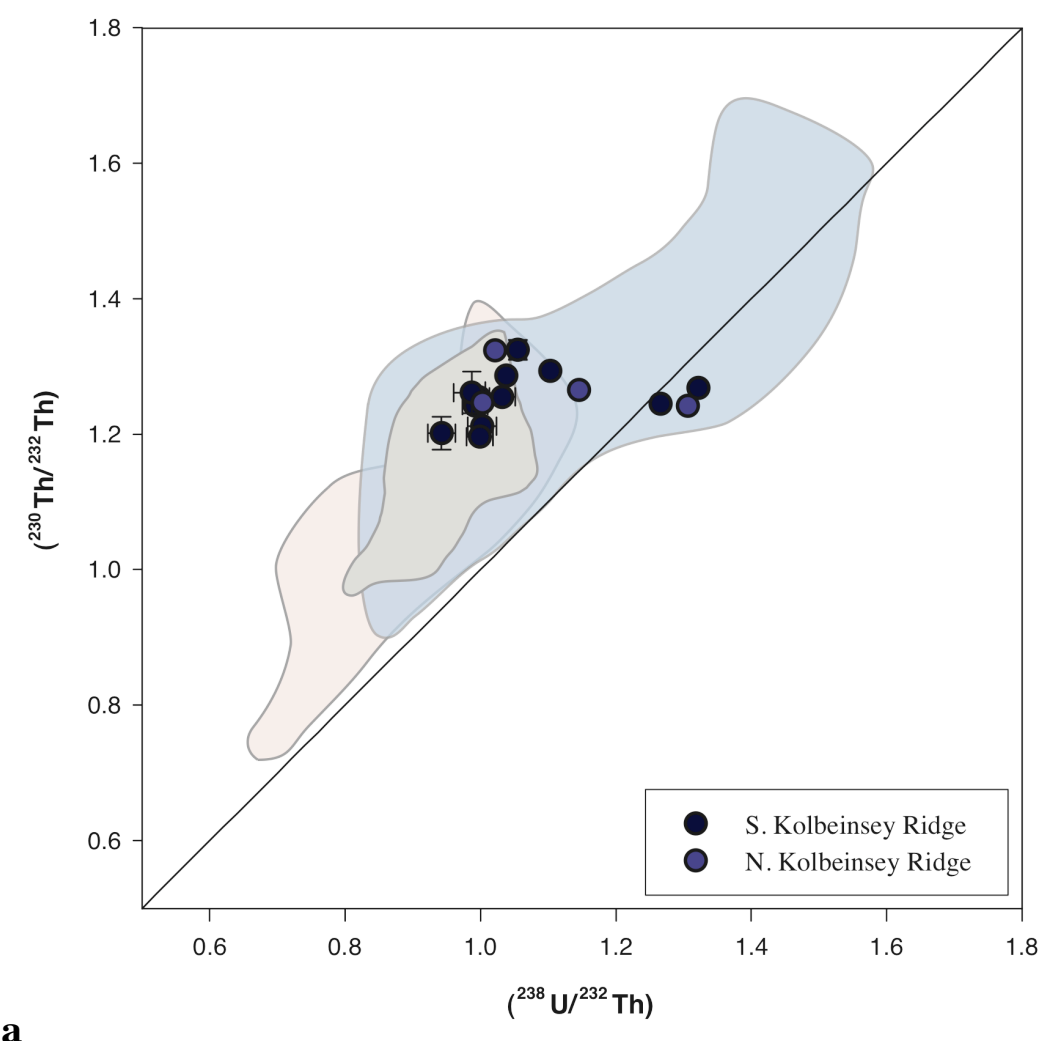

a

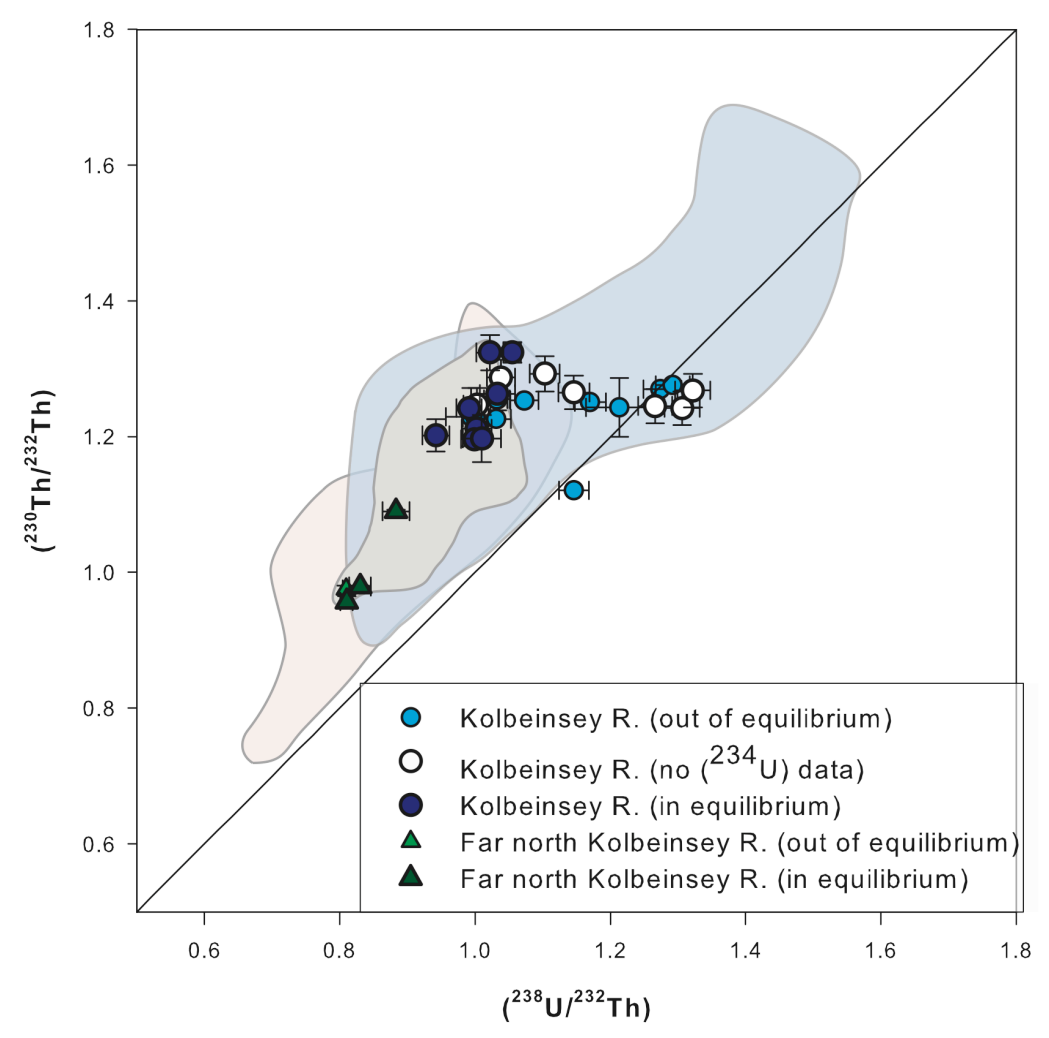




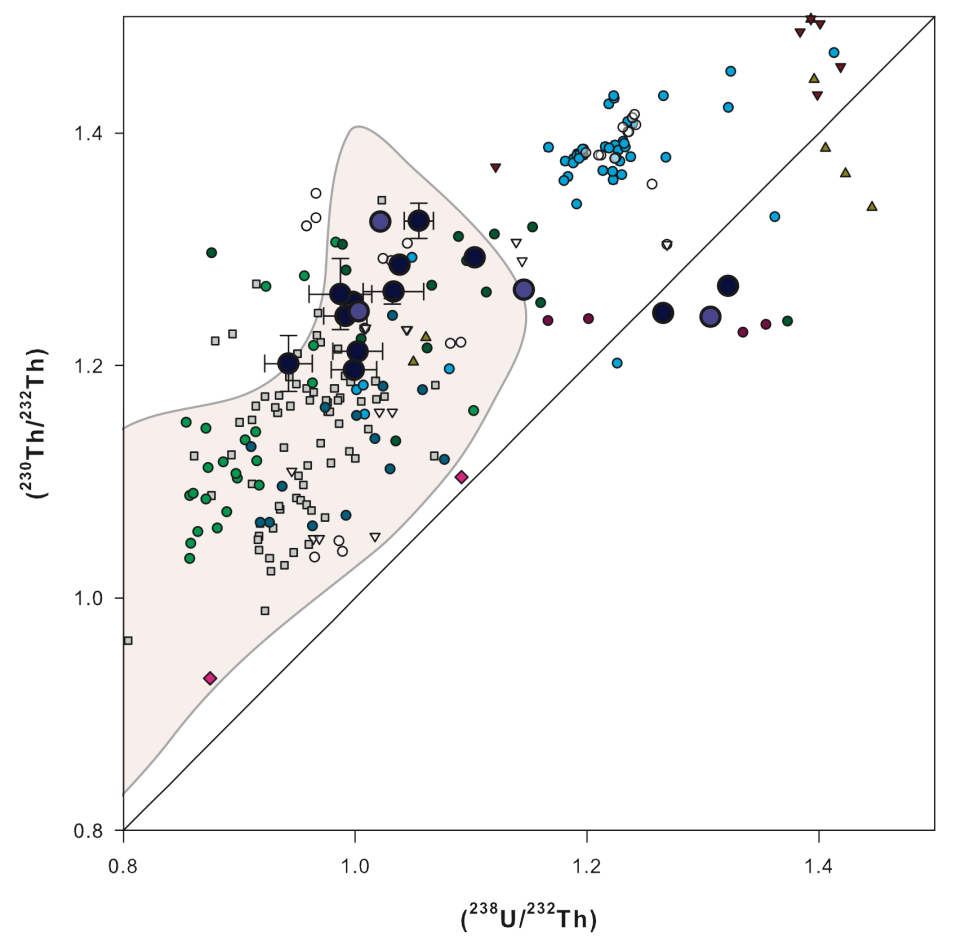

\begin{tabular}{|l|l|}
\hline$\bullet$ & Iceland \\
$\circ$ & EPR, Siquieros Transform \\
$\Delta$ & Garrett Transform \\
$\circ$ & Juan de Fuca Ridge \\
$\bullet$ & $37-40^{\circ}$ N Mid-Atlantic Ridge \\
$\bullet$ & $29-30^{\circ}$ N Mid-Atlantic Ridge \\
$\bullet$ & Australian-Antarctic Discordance \\
$\bullet$ & $22-23^{\circ}$ S EPR \\
$\nabla$ & Tamayo \\
$\bullet$ & Reykjanes Ridge \\
$\nabla$ & Gorda Ridge \\
$\bullet$ & $33^{\circ}$ S Mid-Atlantic Ridge \\
\hline &
\end{tabular}

Figure 3. $\left({ }^{230} \mathrm{Th} /{ }^{232} \mathrm{Th}\right)$ versus $\left({ }^{238} \mathrm{U} /{ }^{232} \mathrm{Th}\right)$ "equiline" diagram for measured basalts from Kolbeinsey Ridge, with the exception of sample TR139 1D-1g $\left(\left({ }^{238} \mathrm{U} /{ }^{232} \mathrm{Th}\right)=1.00,\left({ }^{230} \mathrm{Th} /{ }^{232} \mathrm{Th}\right)\right.$ $=1.25)$, because its large error bars make it difficult to view the rest of the data. For comparison we show (a) fields for global MORB data in blue (BOURDON et al., 1996a; GOLDSTEIN et al., 1989; GOLDSTEIN et al., 1992; GOLDSTEIN et al., 1993; LUNDSTROM et al., 1999; PEATE et al., 2001; SIMS et al., 1995; SIMS et al., 2002; STURM et al., 2000; TEPLEY et al., 2004), global ocean island basalt (OIB) data in red (except for Iceland) (BOURDON et al., 1998; CLAUDE-IVANAJ et al., 1998; CLAUDE-IVANAJ et al., 2001; PIETRUSZKA et al., 2001; SIGMARSSON et al., 1998; SIMS et al., 1999a; SIMS et al., 1995; SIMS and HART, 2006; SIMS et al., 2008b; TURNER et al., 1997; WIDOM et al., 1997), and Icelandic data in gray (KOKFELT et al., 2003; STRACKE et al., 2003a; STRACKE et al., 2003b), (b) the same data, broken down by determination of seawater alteration from measurements of $\left({ }^{234} \mathrm{U} /{ }^{238} \mathrm{U}\right)$, and (c) a field for global OIB data, with individual data points for Iceland and global MORB. The Kolbeinsey Ridge data form a horizontal array that overlaps with Icelandic samples at the high $\left({ }^{230} \mathrm{Th} /{ }^{238} \mathrm{U}\right)$ end and extends to $\left({ }^{230} \mathrm{Th} /{ }^{238} \mathrm{U}\right)<1$. 
a

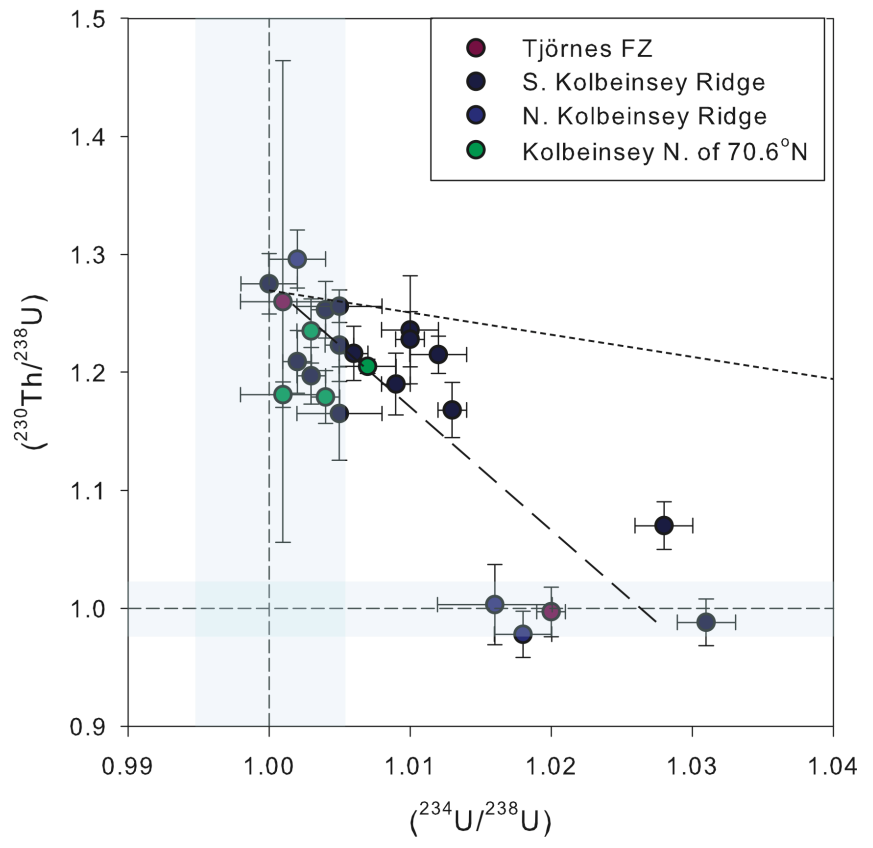

b

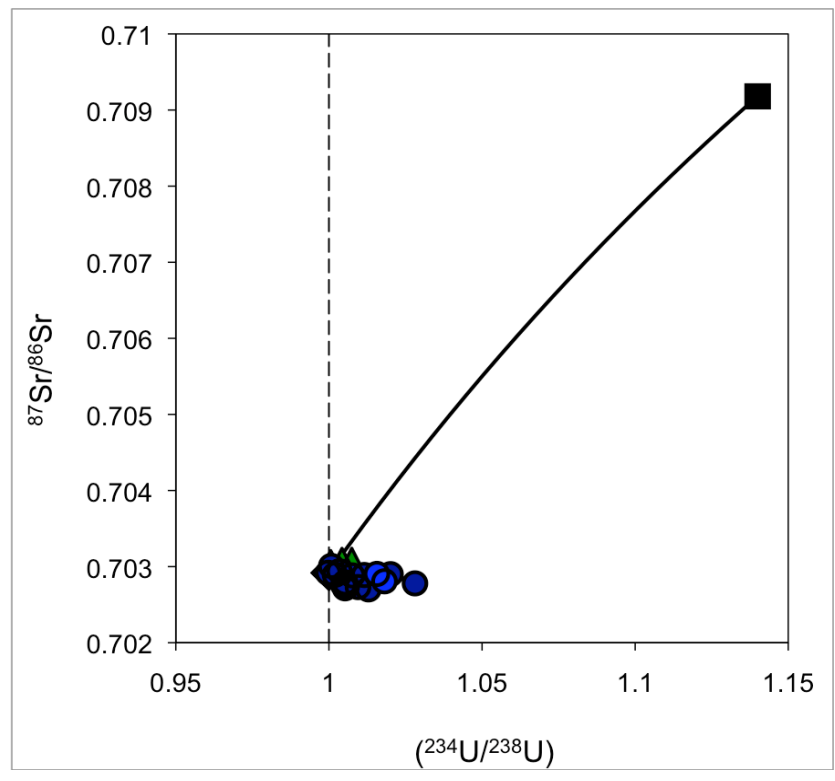

Figure 4. (a) $\left(^{234} \mathrm{U} /{ }^{238} \mathrm{U}\right)$ vs. $\left({ }^{230} \mathrm{Th} /{ }^{238} \mathrm{U}\right)$ for Kolbeinsey Ridge samples. Blue shaded regions are considered in equilibrium within analytical capabilities. The dotted black line shows a mixing trajectory between the average, unaltered Kolbeinsey Ridge sample and seawater with ${ }^{230} \mathrm{Th} /{ }^{238} \mathrm{U}$ ) $=1.0$ and $\left({ }^{234} \mathrm{U} /{ }^{238} \mathrm{U}\right)=1.14$, as described in the text. A simple linear fit to the Kolbeinsey data, as described in the text, is shown with a widely dashed line. (b) $\left({ }^{234} \mathrm{U} /{ }^{238} \mathrm{U}\right) \mathrm{vs} \cdot{ }^{87} \mathrm{Sr} /{ }^{86} \mathrm{Sr}$, showing samples from this study. The black square data point represents seawater, using isotopic compositions from Faure and Mensing (2005). The heavy black line shows a mixing trajectory between sample 1093 (the Kolbeinsey sample with $\left({ }^{234} \mathrm{U} /{ }^{238} \mathrm{U}\right.$ ) nearest to equilibrium) and seawater. U and Sr concentrations in seawater also from Faure and Mensing (2005). 

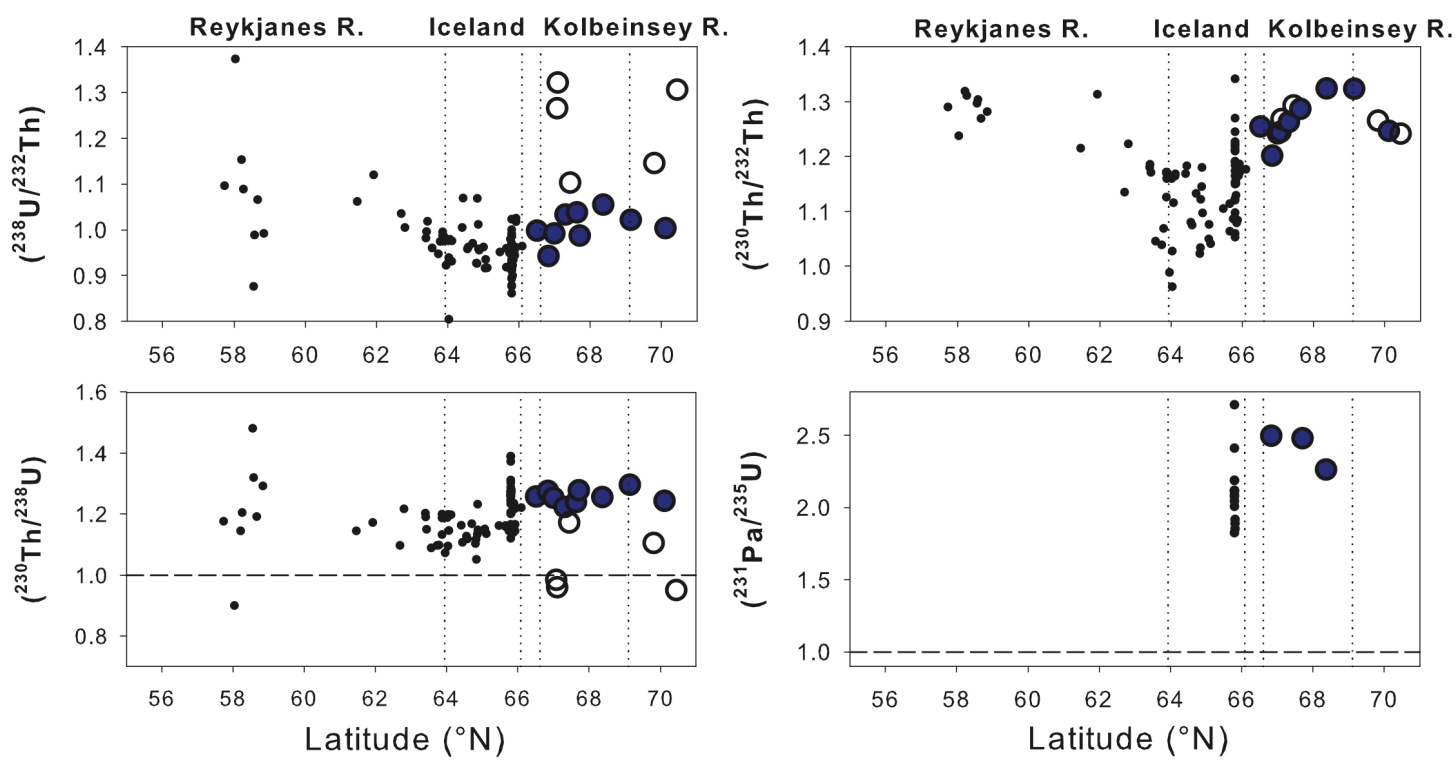

Figure 5. Uranium-series isotopes vs. latitude for the Reykjanes Ridge (PEATE et al., 2001), Iceland (KOKFELT et al., 2003; STRACKE et al., 2006; STRACKE et al., 2003a; STRACKE et al., 2003b), and the Kolbeinsey Ridge (this study); symbols as in Figure 2, with samples potentially altered by seawater as open circles (Section 3.3.1.1). $\left({ }^{230} \mathrm{Th} /{ }^{232} \mathrm{Th}\right.$ ) isotope ratios vary slightly along the ridge and overall mimic or mirror radiogenic isotope ratios as seen in Figure 2, while $\left({ }^{230} \mathrm{Th} /{ }^{238} \mathrm{U}\right)$ and $\left({ }^{238} \mathrm{U} /{ }^{232} \mathrm{Th}\right)$ vary widely but not systematically along the ridge. $\left({ }^{231} \mathrm{~Pa} /{ }^{235} \mathrm{U}\right)>1$ along the entire ridge.

efficiency of Th with TIMS). The similarity of replicate analyses from different facilities and using different mass spectrometry techniques provides confidence in the reliability of our analyses.

The four northernmost, unaltered Kolbeinsey Ridge samples $\left(70.7^{\circ} \mathrm{N}-71.3^{\circ} \mathrm{N}\right)$ have enriched long-lived radiogenic isotope signatures that increase northward towards the Jan Mayen FZ, in keeping with literature observations (Figure 2; (BLICHERT-TOFT et al., 2005; HAASE et al., 2003; MertZ et al., 2004; SCHILLING et al., 1999; TronNes et al., 1999). All of these northernmost samples also have more enriched $U / T h$ and $\left({ }^{238} U{ }^{232} \mathrm{Th}\right)$ ratios than we observe along the rest of the Kolbeinsey consistent with their enriched isotopic signatures (e.g. mean $\varepsilon_{\mathrm{Nd}}=+8.0$ near Jan Mayen vs. +9.7 along the rest of the ridge). Because they record the effects of different melting processes and/or mantle 
source compositions from the rest of the Kolbeinsey Ridge, we exclude them from the modeling described below for the purpose of focusing on how the majority of Kolbeinsey lavas formed.

$\left.{ }^{230} \mathrm{Th} /{ }^{232} \mathrm{Th}\right)$ activities for all other Kolbeinsey Ridge basalts are essentially constant $(1.20-1.32)$, but there is a large range in $\left.{ }^{238} \mathrm{U}{ }^{232} \mathrm{Th}\right)$ activities $(0.94-1.32)$, such that these data lie on a sub-horizontal array on a $\left({ }^{230} \mathrm{Th} /{ }^{232} \mathrm{Th}\right)-\left({ }^{238} \mathrm{U} /{ }^{232} \mathrm{Th}\right)$ "equiline" plot (Figure 3). The Kolbeinsey Ridge basalts show both ${ }^{238} \mathrm{U}$ excesses $\left(\left({ }^{230} \mathrm{Th} /{ }^{238} \mathrm{U}\right)<1\right)$ and ${ }^{230} \mathrm{Th}$ excesses $\left.\left({ }^{230} \mathrm{Th} /{ }^{238} \mathrm{U}\right)>1\right)$, with a full range of $\left({ }^{230} \mathrm{Th} /{ }^{238} \mathrm{U}\right)$ from $0.95-1.30$. However, as shown in Figure 4a and described in Section 3.3.1.1, samples with ${ }^{238} \mathrm{U}$ excesses are affected by secondary processes, and thus we infer that the horizontal array shown in Figure 3reflects shallow alteration of those samples with ${ }^{238} \mathrm{U}$ excess.

\subsubsection{3. ${ }^{235} \mathrm{U}^{231} \mathrm{~Pa}$}

${ }^{235} \mathrm{U}-{ }^{231} \mathrm{~Pa}$ data are also reported in Table 2; there are five $\left({ }^{231} \mathrm{~Pa} /{ }^{235} \mathrm{U}\right)$ measurements in unaltered Kolbeinsey samples, one of which is from the more isotopically enriched region near the Jan Mayen FZ. In all samples $\left({ }^{231} \mathrm{~Pa} /{ }^{235} \mathrm{U}\right)>1$ (Figure 5), consistent with other studies of OIB and MORB studies (LUNDSTROM, 2003; LundSTROM et al., 1998; PicketT and MURRELL, 1997; Sims et al., 1999a; SiMs et al., 2002; SIMS et al., 2008b).

\subsubsection{Radiogenic Isotope Results}

$\mathrm{Sr}, \mathrm{Nd}, \mathrm{Hf}$, and $\mathrm{Pb}$ isotope results for Kolbeinsey Ridge samples are shown in Table 3, Figure 2, and Figure 6. Results from our study are in good agreement with previous measurements from the literature, which are described above in Section 3.2. As shown in Figure 2, radiogenic isotopic ratios for Kolbeinsey samples south of $70.6^{\circ} \mathrm{N}$ are depleted (e.g. $\varepsilon_{\mathrm{Nd}}=+7.33-+8.10,{ }^{87} \mathrm{Sr}{ }^{86} \mathrm{Sr}=0.70272-0.70301$ ), while samples north of $70.6^{\circ} \mathrm{N}$ have more enriched isotopic values $\left(\varepsilon_{\mathrm{Nd}}=+8.43-+10.49,{ }^{87} \mathrm{Sr} /{ }^{86} \mathrm{Sr}=\right.$ 
$0.70306-0.70309)$. This is in keeping with observations from previous studies (e.g. (MERTZ et al., 2004); Section 3.1.2).

\subsection{DISCUSSION}

\subsubsection{Shallow Alteration}

The Kolbeinsey Ridge lavas represent a unique end member among global MORB for the combination of their relative isotopic depletion (BLICHERT-TOFT et al., 2005; HAASE et al., 2003; MertZ et al., 1991; MerTZ and HaASe, 1997; SchilLing et al., 1999), large melt fractions (e.g. low Na; ; KLEIN and LANGMUIR, 1987)), and very shallow ridge axis (KLEIN and LANGMUIR, 1987). In order to constrain how MORB are generated globally, it is of critical importance to understand processes at end member locations like the Kolbeinsey.

As described in Section 3.3.1, measured Kolbeinsey samples' $\left({ }^{234} U /{ }^{238} U\right)$ and $\left({ }^{230} \mathrm{Th} /{ }^{238} \mathrm{U}\right)$ vary systematically in Figure $4 \mathrm{a}$, suggesting a systematic relationship due to secondary processes, such as seawater-rock interaction. (We note that there are also a number of samples with ${ }^{238} \mathrm{U}$ excesses for which $\left({ }^{234} \mathrm{U} /{ }^{238} \mathrm{U}\right)$ was not measured, but given the observed relationship between $\left({ }^{234} \mathrm{U} /{ }^{238} \mathrm{U}\right)$ and $\left({ }^{230} \mathrm{Th} /{ }^{238} \mathrm{U}\right)$ it is likely that these samples have also experienced chemical exchange with seawater.) In Figure 4a, we show a calculated mixing trajectory for a possible closed-system mixing trend between a Kolbeinsey sample with $\left({ }^{234} \mathrm{U} /{ }^{238} \mathrm{U}\right)$ in equilibrium (sample 1093) and hypothesized seawater $\left(\left({ }^{234} \mathrm{U} /{ }^{238} \mathrm{U}\right)=1.14,\left({ }^{230} \mathrm{Th} /{ }^{238} \mathrm{U}\right)=1.0\right)$. Such a trajectory must be a straight line in Figure 4a (as the denominator is the same in both indices), so it cannot fit the Kolbeinsey Ridge data. It is very likely, however, that such surface alteration is instead an open-system process. A number of studies have indicated that surface alteration of basalt by seawater results in addition of $\mathrm{U}$ to altered glass (KROLIKOWSKA-CIAGLO et al., 2007), such that extensive alteration leads to a significant decrease in $\mathrm{Th} / \mathrm{U}$ ratios

(VERMA, 1992). However, recent preliminary results suggest that during minor alteration, 
there is a complex exchange of $U$ between seawater and MORB glass, such that $\left({ }^{234} U /{ }^{238} U\right)$ does not always correlate with U concentrations (GLASS et al., 2005). Thus U concentration cannot be predicted as a function of $\left({ }^{234} \mathrm{U} /{ }^{238} \mathrm{U}\right)$, and likewise $\mathrm{U}$ isotopes cannot be predicted based on $U$ concentration. Likewise, in Figure 4b, we show $\left({ }^{234} \mathrm{U} /{ }^{238} \mathrm{U}\right)$ vs. ${ }^{87} \mathrm{Sr} /{ }^{86} \mathrm{Sr}$ for the samples as well as seawater, with a calculated mixing trajectory between unaltered Kolbeinsey samples and seawater. In this case, the samples' $\mathrm{Sr}$ isotope compositions barely vary with increasing alteration as indicated by $\mathrm{U}$ isotopes, corroborating the observation that exchange between seawater and MORB glass is a complex process.

Nonetheless, for the relatively small change in $\left({ }^{234} \mathrm{U} /{ }^{238} \mathrm{U}\right)$ seen in our samples, we can approximate a linear alteration path. A simple linear fit to the Kolbeinsey Ridge data follows a slope of $-9.4 \pm 0.5$, excluding samples north of $70.6^{\circ} \mathrm{N}$ on the ridge (including those samples results in a slightly different slope of $-7.7 \pm 0.5)$. In Table 3 we calculate $\left({ }^{230} \mathrm{Th} /{ }^{238} \mathrm{U}\right)$ values for all samples, corrected back to a $\left({ }^{234} \mathrm{U} /{ }^{238} \mathrm{U}\right)$ value of 1.0. Corrected $\left({ }^{230} \mathrm{Th} /{ }^{238} \mathrm{U}\right)$ values span a range of $1.149-1.334$, which is similar to the range of uncertainty among samples within analytical uncertainty of secular equilibrium for $\left({ }^{234} \mathrm{U} /{ }^{238} \mathrm{U}\right)$ (i.e. samples with ${ }^{234} \mathrm{U} /{ }^{238} \mathrm{U}=1.00 \pm 0.05$ have $\left({ }^{230} \mathrm{Th} /{ }^{238} \mathrm{U}\right)$ of $\left.1.17-1.296\right)$. Samples with no $\left({ }^{234} \mathrm{U} /{ }^{238} \mathrm{U}\right)$ measured, if assumed to lie on the best linear fit to the data (Figure 4a), should have corrected $\left({ }^{230} \mathrm{Th} /{ }^{238} \mathrm{U}\right)=1.28 \pm 0.54$ when $\left({ }^{234} \mathrm{U} /{ }^{238} \mathrm{U}\right)=1.0$.

This suggests that Kolbeinsey MORB in fact have universally high $\left({ }^{230} \mathrm{Th} /{ }^{238} \mathrm{U}\right)$ values upon eruption, and that the measured ${ }^{238} \mathrm{U}$ excesses result from shallow crustal alteration. This is plausible, considering the thick crust along the Kolbeinsey Ridge and the depleted, easily contaminated nature of these MORB. However, without direct analysis of $\left({ }^{234} \mathrm{U} /{ }^{238} \mathrm{U}\right)$ on those samples, the array described in Section 3.3.2 might reflect primary melting processes and needs to be considered further. In the following section we consider how such an array may be explained using various forward melting model calculations. 


\subsubsection{Modeling the Horizontal Kolbeinsey Array}

If it in fact reflects primary melt composition, we have measured a very striking data array (Figure 3), which has large variations in $\left({ }^{238} \mathrm{U} /{ }^{232} \mathrm{Th}\right)$ coupled with nearly constant $\left({ }^{230} \mathrm{Th} /{ }^{232} \mathrm{Th}\right)$ for the Kolbeinsey Ridge. The observation that these lavas also have nearly uniform $\mathrm{Nd}, \mathrm{Sr}, \mathrm{Hf}$, and $\mathrm{Pb}$ isotopic compositions (Figure 2, Figure 6) indicates that melting processes and not source variability must be the dominant mechanism producing the observed range of $\left({ }^{230} \mathrm{Th} /{ }^{238} \mathrm{U}\right)$.

Given the indication of melting process control over ${ }^{238} \mathrm{U}^{230} \mathrm{Th}$ systematics for Kolbeinsey lavas, the simplest way to model this horizontal array is using a timeindependent, batch melting model with a single-lithology, peridotitic source. However, this simple model cannot account for the nearly uniform major and trace element compositions of the samples (we would expect batch melting to generate trace element systematics that parallel the U-Th fractionation observed; see Section 3.4.2.1). Previously, a heterogeneous source control has been suggested for data arrays on $\left({ }^{238} \mathrm{U} /{ }^{232} \mathrm{Th}\right)$ vs. $\left({ }^{230} \mathrm{Th} /{ }^{232} \mathrm{Th}\right)$ diagrams (LunDSTROM et al., 1998). If this were the case, then we would expect the enriched lavas along the array (i.e. lower U/Th ratios) to have more enriched isotopic signatures (e.g. higher ${ }^{87} \mathrm{Sr} /{ }^{86} \mathrm{Sr}$ ). Figure 6 shows that this is not the situation for Kolbeinsey MORB, however, so ingrowth of melts from two distinct source components (one enriched and one depleted) is not consistent with our observations.

In the following discussion we systematically explore more complex melting scenarios to explain the suggested array in terms of the ${ }^{238} \mathrm{U}_{-}^{230} \mathrm{Th}$, radiogenic isotopes, and major and trace element compositions of these lavas. Similar to Kolbeinsey Ridge, a lack of correlation between radiogenic isotopes and $\left({ }^{230} \mathrm{Th} /{ }^{238} \mathrm{U}\right)$ was also observed for 9$10^{\circ} \mathrm{N}$ on the EPR. The proposed explanation for the $9-10^{\circ} \mathrm{N}$ EPR N-MORB data was that the mantle beneath that region is homogeneous over the length scale of melting (SIMS et al., 2003; SIMS et al., 2002), such that melt transport occurs via both low-porosity reactive transport and high-porosity non-reactive transport. In this scenario, the erupted 
magmas are mixtures from the different transport regimes (JULL et al., 2002; KELEMEN et al., 1997; LUNDSTROM, 2000; SiMS et al., 2002; SiMS et al., 1999b). If reactive porous flow melting (also called "chromatographic" melting in the literature (SPIEGELMAN and ELLIOTT, 1993)) is important for the Kolbeinsey Ridge, we expect the results of such melting calculations to produce large-degree melts (i.e. low $\mathrm{Na}_{8}$ ) and depleted trace element ratios (e.g. low $\mathrm{La} / \mathrm{Sm}_{\mathrm{n}}$ ) similar to Kolbeinsey Ridge lavas, in addition to the observed ${ }^{238} \mathrm{U}^{230} \mathrm{Th}$ data array.

\subsubsection{Time-Independent Melting}

Time independent (batch and fractional) models are the simplest melting model calculations, and they can easily generate ${ }^{230} \mathrm{Th}$-excess or ${ }^{238} \mathrm{U}$-excess in melts by simple chemical fractionation of $\mathrm{U}$ and $\mathrm{Th}$. The $\left({ }^{230} \mathrm{Th} /{ }^{232} \mathrm{Th}\right)$ ratio of the melt and the residue remain constant, since without consideration of the time of melt production, there is neither decay nor ingrowth of ${ }^{230} \mathrm{Th}$. In the presence of garnet, small-degree, timeindependent melts have large ${ }^{230} \mathrm{Th}$-excesses due to the control of garnet on bulk partition coefficients. In the absence of garnet (or some clinopyroxene compositions that can also produce moderate ${ }^{230} \mathrm{Th}$ excess (e.g. 20\%; (LANDWEHR et al., 2001; WoOD et al., 1999)), fractionation is mainly controlled by clinopyroxene with $\mathrm{D}_{\mathrm{Th}}>\mathrm{D}_{\mathrm{U}}$, creating small ${ }^{238} \mathrm{U}$ excesses in the produced melt (BEattie, 1993a; BeAtTiE, 1993b; ElKins et al., 2008; HAuri et al., 1994; LA TOURETTE and BurnetT, 1992; LA TOURETTE et al., 1993; LANDWEHR et al., 2001; LUNDSTROM et al., 1994; SALTERS and LONGHI, 1999; SALTERS et al., 2002; WoOD et al., 1999). As melting progresses and degree of melting (F) increases, all melt compositions rapidly return to the equiline (where $\left({ }^{230} \mathrm{Th} /{ }^{238} \mathrm{U}\right.$ ) and $\left.\left({ }^{231} \mathrm{~Pa} /{ }^{235} \mathrm{U}\right)=1\right)$, such that $\left({ }^{231} \mathrm{~Pa} /{ }^{235} \mathrm{U}\right)$ and $\left({ }^{230} \mathrm{Th} /{ }^{238} \mathrm{U}\right)$ disequilibria can only be preserved in small-degree melts (generally $<1 \%$, though the precise value depends on the $\mathrm{D}$ values chosen).

To formally test and address time-independent models discussed above, we present results for batch and fractional melting calculations for a peridotitic source. In these calculations, all sources begin in a state of secular equilibrium. We choose a 

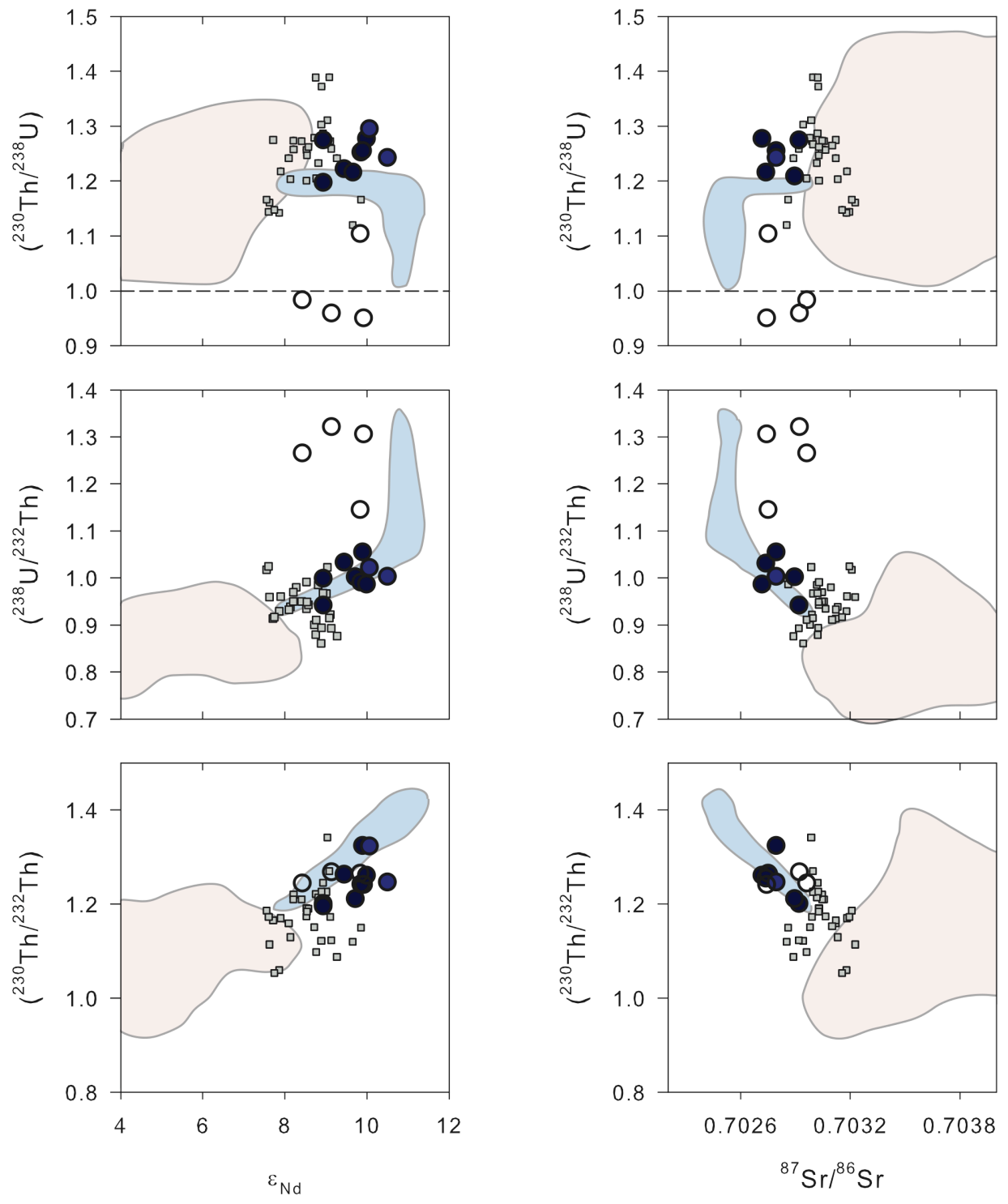

Figure 6. $\left({ }^{230} \mathrm{Th} /{ }^{238} \mathrm{U}\right)$ (top panels), $\left({ }^{232} \mathrm{Th} /{ }^{230} \mathrm{Th}\right)$ (middle panels), and $\left({ }^{238} \mathrm{U} /{ }^{232} \mathrm{Th}\right.$ ) (bottom panels) for Kolbeinsey Ridge basalts, plotted versus radiogenic isotope ratios ${ }^{87} \mathrm{Sr} /{ }^{86} \mathrm{Sr}$ (left) and $\varepsilon_{\mathrm{Nd}}$ (right). Data symbols and fields as in Figure 3, with potentially altered samples as open circles (Section 3.3.1.1). Kolbeinsey MORB are relatively homogeneous in $\left({ }^{230} \mathrm{Th} /{ }^{232} \mathrm{Th}\right),{ }^{87} \mathrm{Sr} /{ }^{86} \mathrm{Sr}$, and $\varepsilon_{\mathrm{Nd}}$, but not $\left({ }^{238} \mathrm{U} /{ }^{232} \mathrm{Th}\right)$ or $\left({ }^{230} \mathrm{Th} /{ }^{238} \mathrm{U}\right)$, indicating that while $\left({ }^{230} \mathrm{Th} /{ }^{232} \mathrm{Th}\right)$ reflects source composition, the amount of ${ }^{238} \mathrm{U}_{-}{ }^{230} \mathrm{Th}$ disequilibrium is not source-controlled. Overall, radiogenic isotopes vary very little along the Kolbeinsey Ridge.

peridotite source with initial $\left({ }^{238} \mathrm{U} /{ }^{232} \mathrm{Th}\right)=\left({ }^{230} \mathrm{Th} /{ }^{232} \mathrm{Th}\right)=1.25$ to best generate melt compositions near the $\left({ }^{230} \mathrm{Th} /{ }^{232} \mathrm{Th}\right)$ values of the samples on the horizontal Kolbeinsey 
Ridge array, and we calculate melts for both $100 \mathrm{~km}$ and $55 \mathrm{~km}$ melting columns. Hirschmann et al. (1999) found that productivity variations are significant during peridotite melting, so all of our peridotite melt calculations consider variable productivities. The relationship between the rate of melt production and the degree of melting in our calculations is shown in Figure 7 and is modeled after MELTS calculation results from Hirschmann et al. (1999), but with a lower peak melt productivity, due to the tendency for MELTS to overestimate total degree of melting. Unlike the approach by others like Braun et al. (2000), who estimate a fixed productivity of 1\%/kbar above the dry solidus, we choose to more closely emulate the progressively increasing productivity predicted by MELTS. Mineral partition coefficients for the garnet peridotite melt regime (deeper than $75 \mathrm{~km}$ ) and spinel peridotite regime (shallower than $75 \mathrm{~km}$ ) are fixed (Table

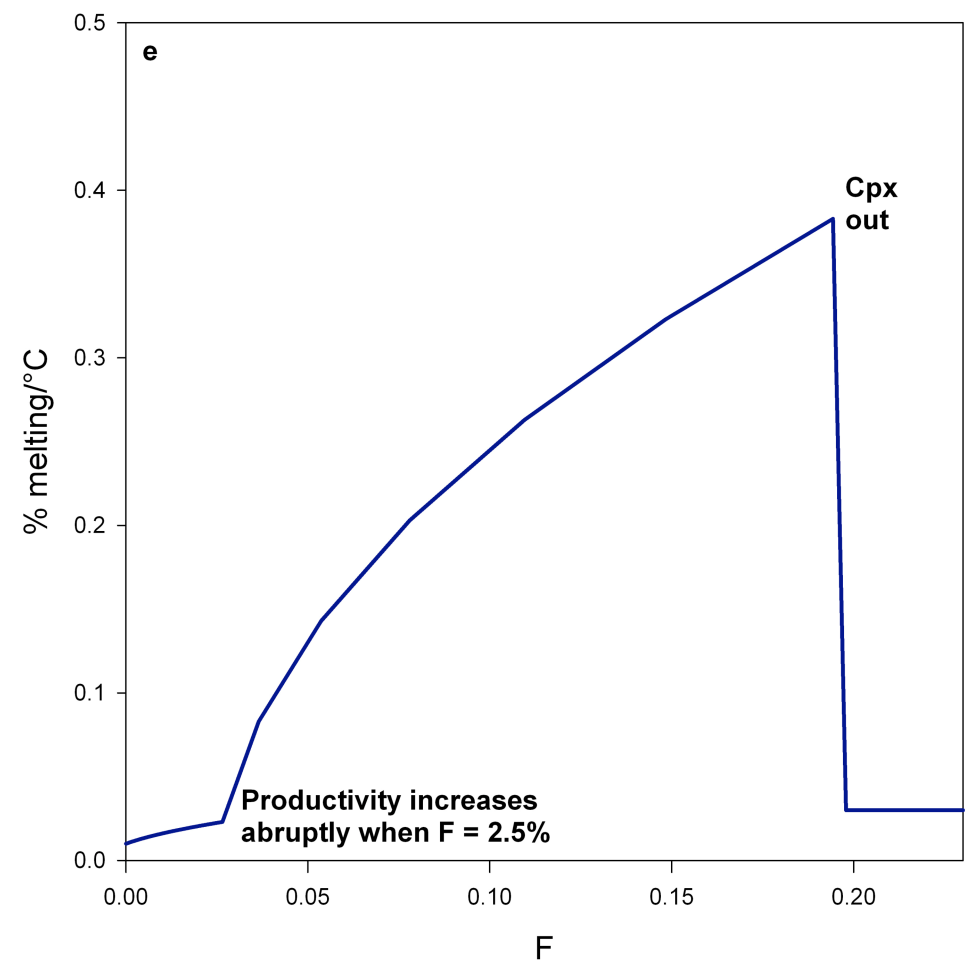

Figure 7. Productivity with distance along the melting column $(\mathrm{dF} / \mathrm{dz})$ vs. total degree of melting (F) input parameters for all peridotite melting models, as discussed in Section 3.4.1 and the Appendix. Chromatographic garnet peridotite melt trajectories in particular have a number of sharp turns and "kinks," which occur when there are changes in the bulk sense of U-Th partitioning (e.g. when garnet is exhausted or is no longer stable) and when there are significant increases or decreases in melt productivity (e.g. when clinopyroxene is exhausted, causing a large, sudden drop in melt productivity). 


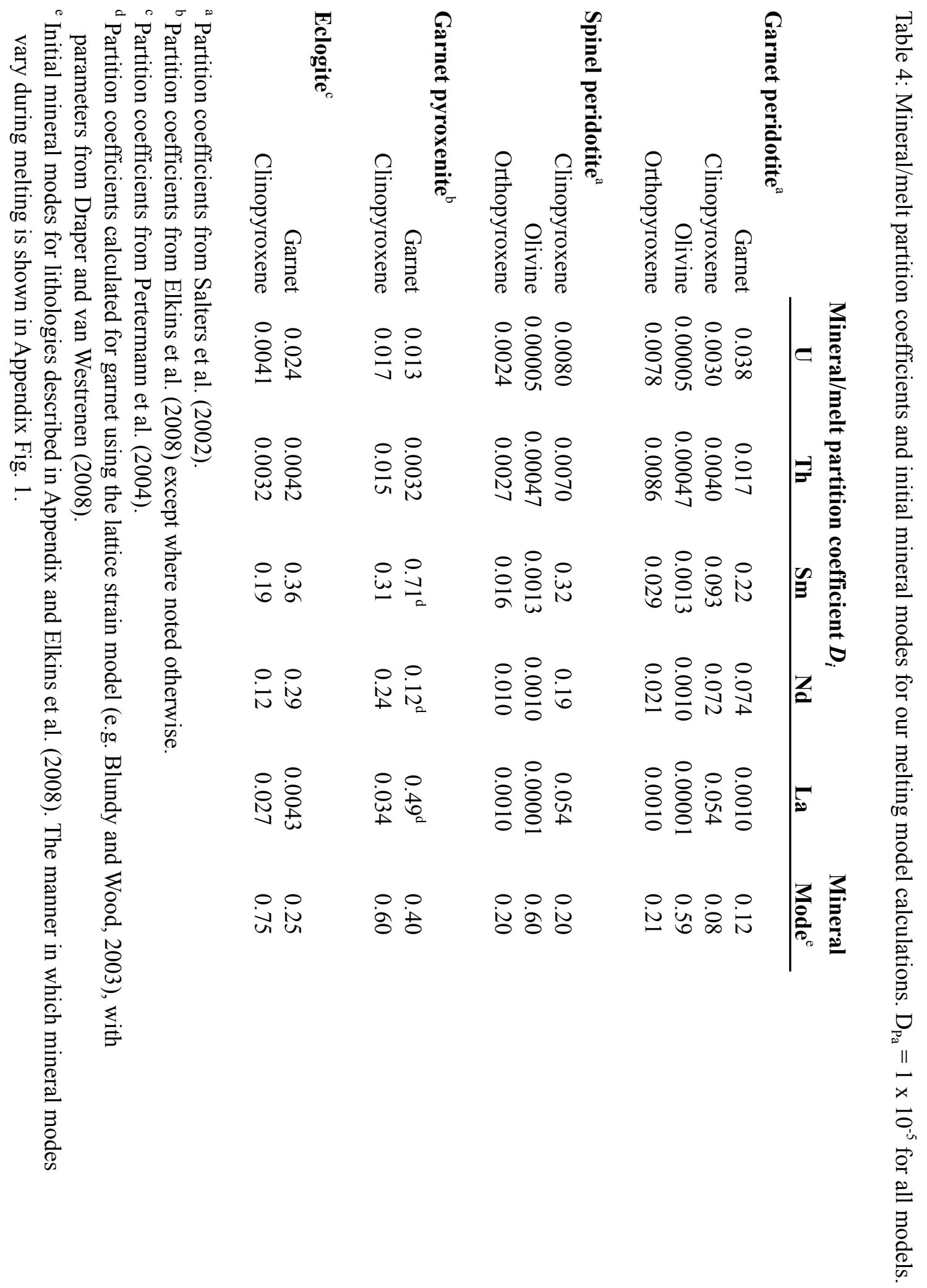


4), but peridotite mineral modes (Table 4) vary non-linearly during melting to approximate experimental observations from the literature as closely as possible (HIRSCHMANN et al., 1999). (Further details about these and our other melt calculations are provided in the Appendix.)

In Figure 8a we show results for calculations of time independent melting of peridotitic melting columns. Mixing deep and shallow batch or fractional melts from a single $100 \mathrm{~km}$ melting column (Figure 8a; Appendix) can generate a horizontal slope, but neither melt trajectory can generate enough ${ }^{238} \mathrm{U}$ excess anywhere in the melting column to explain the Kolbeinsey Ridge data (fractional melts are controlled by the initial melt compositions and generate no ${ }^{238} \mathrm{U}$ excess anywhere, and batch melts can generate only very small ${ }^{238} \mathrm{U}$ excesses). For each melt calculation the total degrees of melting must be small to observe any disequilibria $\left(<1 \%\right.$ melting for ${ }^{230} \mathrm{Th}$ excesses, and batch melts from shallower depths only preserve ${ }^{238} \mathrm{U}$ excesses of at most $\sim 1 \%$ when degrees of melting are below 5\%). Estimated degrees of melting for Kolbeinsey Ridge from major elements $\left(\mathrm{Na}_{8}\right.$ and $(\mathrm{Ca} / \mathrm{Al})_{8}$ calculations) range from 11 to $28 \%$, making these timeindependent melting models problematic (SCHILLING et al., 1999). We also note that with time-independent melting, we would expect lavas with ${ }^{230} \mathrm{Th}$ excesses to be trace element enriched and ${ }^{238} \mathrm{U}$ excess basalts to be trace element depleted, which is not observed: all of the Kolbeinsey basalts are trace element depleted. Furthermore, the Kolbeinsey Ridge has a half-spreading rate of $0.9 \mathrm{~cm} / \mathrm{yr}$, which translates to upwelling rates of a similar magnitude. Previous studies (BOURDON et al., 2006; KOKFELT et al., 2003; SiMS et al., 1999a) have demonstrated for ocean-island basalts (OIB) that at slow upwelling rates, ingrowth becomes significant and cannot be ignored. This should hold true for ridge settings as well. Thus, as outlined above, we do not consider time-independent melting to be plausible for explaining the Kolbeinsey Ridge lavas. Below we consider timedependent melting calculations. 


\subsubsection{Dynamic and Reactive Porous Flow Melting}

Dynamic melting calculations consider the effects of time on the U-series disequilibria during magma genesis, as melts are extracted fractionally above a threshold/constant critical residual melt porosity from an upwelling, melting residue (MCKENZIE, 1985; WILLIAMS and GILL, 1989). Ingrowth of daughter ${ }^{230} \mathrm{Th}$ from parent ${ }^{238} \mathrm{U}$ during ascent of the solid residue is considered. However, because melts are
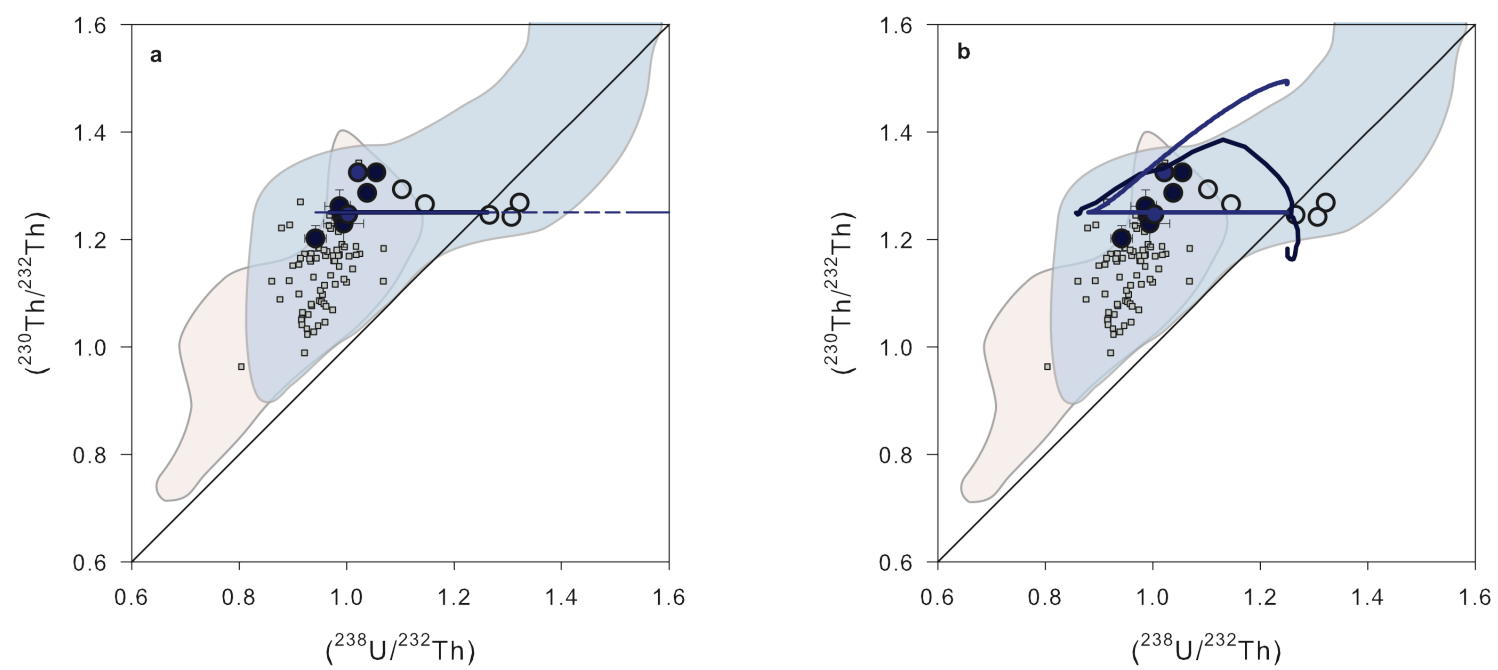

Figure 8. Equiline diagrams for the Kolbeinsey Ridge basalts with (a) time-independent, batch (dark blue line) and fractional (light blue line) garnet peridotite melt trajectories, and (b) a reactive porous flow melt trajectory (dark blue line); data symbols and fields as in Figure 6.

extracted instantaneously, $\mathrm{U}$ and $\mathrm{Th}$ are removed so efficiently by melting that the aggregated melt composition is controlled by the initial small-degree melts. This means that ${ }^{238} \mathrm{U}$ excess cannot be produced in a dynamic melting column that initiates in the garnet peridotite stability field, leaving no mechanism for mixing ${ }^{230} \mathrm{Th}$ excess melts from deep in the melting column with shallower, ${ }^{238} \mathrm{U}$ excess melts (see Appendix for evidence from calculations of continuous dynamic melting of a garnet peridotite source).

Producing the horizontal Kolbeinsey array by melt mixing requires that the mixing components have the same $\left({ }^{230} \mathrm{Th} /{ }^{232} \mathrm{Th}\right)$. A purely theoretical mechanism for this would be: 1) dynamically melting a source to produce a low-degree melt with $\left({ }^{230} \mathrm{Th} /{ }^{238} \mathrm{U}\right)>1$ and a residue with $\left.\left.{ }^{230} \mathrm{Th} /{ }^{238} \mathrm{U}\right)<1,2\right)$ generate a second, large degree melt of the residue 
with $\left({ }^{230} \mathrm{Th} /{ }^{238} \mathrm{U}\right)<1$, and 3) mix those two melts. While this scenario can produce a horizontal array spanning the range of Kolbeinsey Ridge MORB $\left({ }^{238} \mathrm{U} /{ }^{232} \mathrm{Th}\right)$ it also produces trends in the other trace element data that are not observed in the basalts. Such a scenario would generate systematic trace element variations along the horizontal array, with extreme trace element depletion in the ${ }^{238} \mathrm{U}$ excess endmember melt and relative trace element enrichment in the ${ }^{230}$ Th excess melt. This is not the case for the Kolbeinsey Ridge samples, which rules out a dynamic melting process for the origin of the Kolbeinsey MORB.

Unlike the efficient, disequilibrium extraction modeled by dynamic melting calculations, reactive porous flow melting takes into account the time scales of melting and melt migration (i.e. enhanced production of disequilibrium in melts due to ingrowth effects) resulting from chromatographic effects (i.e. melt and solid residence times and effective velocities of trace elements with different partitioning behavior) in a continuously equilibrating melt migrating through upwelling solid mantle. Such a model can generate large disequilibria from depth, particularly during relatively slow upwelling. We use the same partition coefficients, productivity variations, and starting conditions for our reactive porous flow model as for the $100 \mathrm{~km}$ batch, fractional, and dynamic melt calculations described above and in the Appendix.

As discussed above, the Kolbeinsey array requires the production of ${ }^{230} \mathrm{Th}$ excess melts from deep in the melting column as well as shallower melts with ${ }^{238} \mathrm{U}$ excess. This idea is not new: the observation that ${ }^{230} \mathrm{Th} /{ }^{238} \mathrm{U}$ is negatively correlated with the parameter $\alpha_{\mathrm{Sm}-\mathrm{Nd}}$ led to the suggestion that small and large degree melts (with no intermediate melt fractions) were involved in MORB genesis (SIMS et al., 1995) and then subsequently the observation of a negative global correlation between $\left({ }^{230} \mathrm{Th} /{ }^{238} \mathrm{U}\right)$ and $\left({ }^{226} \mathrm{Ra} /{ }^{230} \mathrm{Th}\right)$ in definitively young MORB suggested mixing between deep, ${ }^{230}$ Th excess melts and shallow melts with preserved ${ }^{226}$ Ra excesses (JULL et al., 2002; KELEMEN et al., 1997; SIMS et al., 2003; SIMS et al., 2002). Being able to detect melts from two different depths in a melting column requires that melts be extracted efficiently from deep in the mantle. Extraction of melts from the deep, garnet-bearing part of a peridotitic melt column can be envisioned in 
two ways: allowing the melts produced to migrate laterally and thus extract some of the deep, small degree melts from the corners of a two-dimensional, triangular melting regime; or rapidly extracting such melts through a higher-porosity zone, such as a dunite channel (Appendix Figure 1) (KELEMEN and DiCK, 1995; KELEMEN et al., 1997). These two possibilities are identical to calculate, as long as the extraction of the deep melt is isolated and rapid. Several workers have shown that melts can be removed rapidly enough in high-porosity channels to preserve ${ }^{230} \mathrm{Th}$-excesses generated at the bottom of the melting column (JULL et al., 2002; SIMS et al., 2002; TEPLEY et al., 2004), and that such processes may also preserve a wide range of possible trace element compositions (SPIEGELMAN and KELEMEN, 2003). Thus, for the sake of simplicity, we calculate a single melting column that originates in the garnet stability field for peridotite, and expand on previous model observations that mixing of deeper and shallower melts in such a column is possible and numerically robust. Our calculations add the complexity of variable bulk partition coefficients and productivities to previous calculations of this sort from the literature.

As shown in Figure 8b, reactive porous flow in a melt column can generate both ${ }^{230} \mathrm{Th}$ - and ${ }^{238} \mathrm{U}$ excesses with changing mineral modes and melt productivities along the column. The reactive porous flow model trajectory undergoes abrupt changes in direction and curvature that reflect changing bulk partition coefficients and melt productivity during ascent. We are able to preserve ${ }^{230} \mathrm{Th}$ excesses until melting is well within the spinel peridotite stability field, as well as significant ${ }^{238} \mathrm{U}$ excesses in the shallowest melts despite total degrees of melting up to or even exceeding $20 \%$. This works well with the predictions for degrees of melting for Kolbeinsey Ridge lavas from major elements (i.e. $\mathrm{Na}_{8},(\mathrm{Ca} / \mathrm{Al})_{8}$ (KLEIN and LANGMUIR, 1987)) We note, however, that the ${ }^{238} \mathrm{U}$ excesses generated by the model calculation shown in Figure $8 \mathrm{~b}$ are insufficiently large to explain all of the Kolbeinsey data.

However, all of these models, including reactive porous flow, predict that trace element concentrations (e.g. U concentrations) or ratios like $\mathrm{La} / \mathrm{Sm}_{\mathrm{N}}$ or $\mathrm{Sm} / \mathrm{Nd}$, should vary systematically along the mantle array. This is not the case. As described in Section 
3.4.1, we consider it likely that instead, the samples with low $\left({ }^{230} \mathrm{Th} /{ }^{238} \mathrm{U}\right)$ from Kolbeinsey Ridge are the result of shallow interaction with and alteration by seawater. If this is indeed the case, the observed horizontal array is not the result of primary magmatic processes, and unaltered Kolbeinsey samples have universally large ${ }^{230}$ Th excesses. A long melting column that originates well below the garnet-spinel transition can generate both ${ }^{230} \mathrm{Th}$ excesses and the large degrees of melting predicted for Kolbeinsey Ridge. This generally homogeneous data set is relatively straightforward to reproduce.

However, calculated $\alpha_{\mathrm{Sm}-\mathrm{Nd}}$ values $\left(\alpha_{\mathrm{Sm}-\mathrm{Nd}}=(\mathrm{Sm} / \mathrm{Nd})_{\text {sample }} /(\mathrm{Sm} / \mathrm{Nd})_{\text {source }}\right.$, where $(\mathrm{Sm} / \mathrm{Nd})_{\text {source }}$ is calculated from each sample's $\varepsilon_{\mathrm{Nd}}$ value for a model age of $\left.1.8 \mathrm{Ga}\right)$ for Kolbeinsey lavas range from 0.91 to 1.24 and are almost all greater than one (Figure 9a). $\mathrm{Sm}$ and $\mathrm{Nd}$ partitioning behavior is such that melting alone cannot produce this sense of fractionation, suggesting that $\mathrm{Sm} / \mathrm{Nd}$ ratios in the melts are decoupled from the long-lived source composition. These $\alpha_{\mathrm{Sm}-\mathrm{Nd}}$ values suggest that the $1.8 \mathrm{Ga}$ model age is incorrect. We also note that other trace element ratios (e.g. $\left.\mathrm{La} / \mathrm{Sm}_{\mathrm{N}}\right)$ are more depleted than predicted by our melting models (Figure 9b).
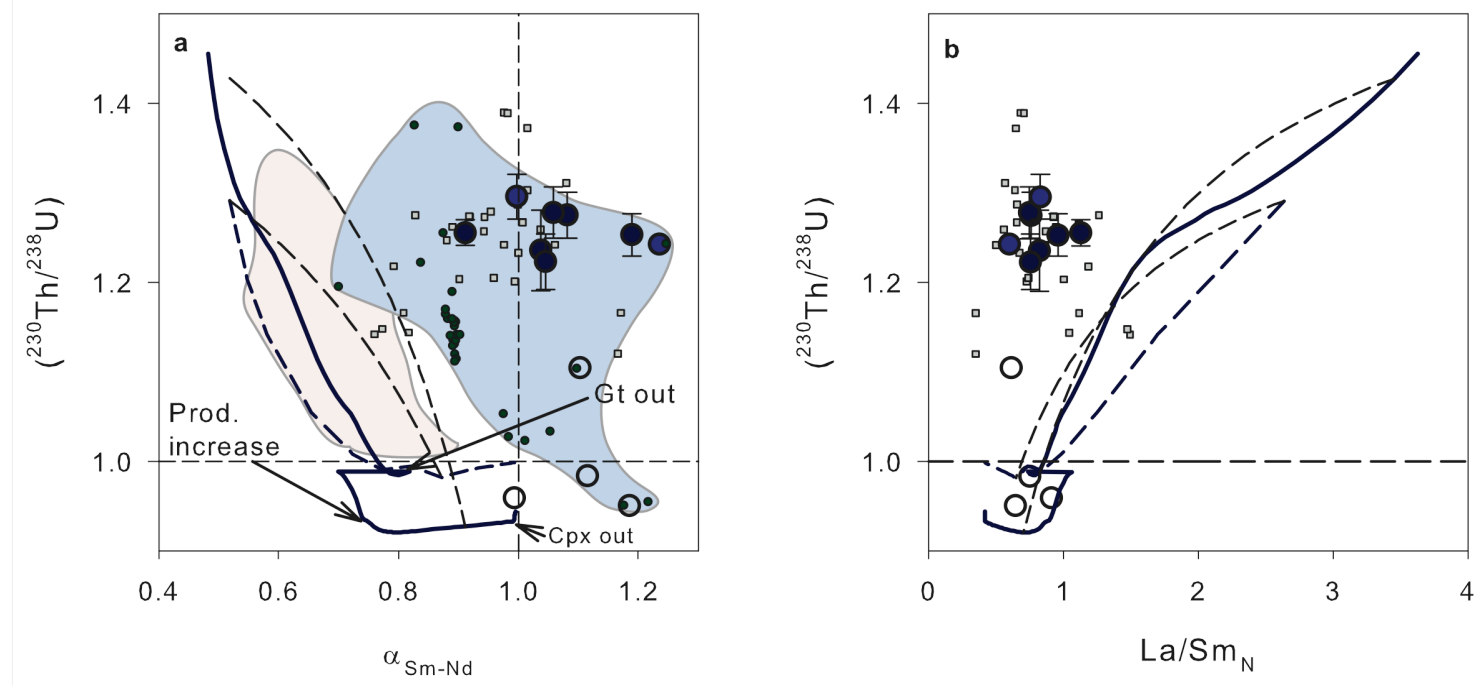

Figure 9. Measured data from Kolbeinsey Ridge, and garnet pyroxenite modeled melt trajectories with binary mixing curves. Blue solid lines represent calculated reactive porous flow melt trajectories and blue dashed lines indicate batch melts; data symbols and fields as in Figure 6. (a) $\left({ }^{230} \mathrm{Th} /{ }^{238} \mathrm{U}\right)$ vs. $\alpha_{\mathrm{Sm}-\mathrm{Nd}}$ diagram, and $(\mathrm{b})\left({ }^{230} \mathrm{Th} /{ }^{238} \mathrm{U}\right)$ vs. $(\mathrm{La} / \mathrm{Sm})_{\mathrm{N}}$ ratios, with both timeindependent and time-dependent melt trajectories for models described in Section 4.1.3. 
These anomalous trace element characteristics (very depleted $\mathrm{La} / \mathrm{Sm}_{\mathrm{n}}$, and $\alpha_{\mathrm{Sm}-\mathrm{Nd}}$ $>1$ ) are inconsistent with a simple progressive melting scenario and are in direct contrast to locations where $\alpha_{\mathrm{Sm}-\mathrm{Nd}}$ values are consistent with the U-series systematics (e.g. the Juan de Fuca and Gorda Ridges (SIMS et al., 1995), and the EPR (SIMS et al., 2002)). The Kolbeinsey Ridge $\alpha_{\text {Sm-Nd }}$ values imply in particular that the assumed model age of $1.8 \mathrm{Ga}$ for the source is incorrect, i.e. the source rock with which the melt last interacted must have recently become more depleted in $\mathrm{Nd}$ relative to $\mathrm{Sm}$ than the long-lived mantle source. Thus the trace element budget of the source has been potentially perturbed, but this must have occurred recently and shallow enough that it has not strongly affected the ${ }^{238} \mathrm{U}^{230} \mathrm{Th}$ disequilibria. A recent source depletion event could be explained by incursion into the source region of depleted residue from the nearby Iceland plume. However, a two-stage melting model would require an extremely hot mantle to generate the large degrees of melting required for Kolbeinsey Ridge. Alternately, the source age may be considerably younger than the average mantle model age of $1.8 \mathrm{Ga}$, perhaps because the Greenland basin only began rifting 55 Ma and the Kolbeinsey Ridge is the result of a more recent ridge jump that occurred between 26-45 Ma.

We also calculated $\left({ }^{231} \mathrm{~Pa} /{ }^{235} \mathrm{U}\right)$ in reactive porous flow and batch melts. The modeled melts reach initially large ${ }^{231} \mathrm{~Pa}$ excesses at low degrees of melting (e.g. $\left({ }^{231} \mathrm{~Pa} /{ }^{235} \mathrm{U}\right)>5$ for the initial batch melt $)$, and both reactive porous flow and batch melting models generate much larger ${ }^{231} \mathrm{~Pa}$ excesses $\left(\right.$ modeled $\left({ }^{231} \mathrm{~Pa} /{ }^{235} \mathrm{U}\right)=7.0$ when $\left({ }^{230} \mathrm{Th} /{ }^{238} \mathrm{U}\right)=1.25$, as in Kolbeinsey Ridge basalts) than observed for the Kolbeinsey $\operatorname{MORB}\left(\left({ }^{231} \mathrm{~Pa} /{ }^{235} \mathrm{U}\right)=2.263-2.495\right)$. Sims et al. (2002) and Stracke et al. (2006) were able to reproduce $\left({ }^{231} \mathrm{~Pa} /{ }^{235} \mathrm{U}\right)$ and $\left({ }^{230} \mathrm{Th} /{ }^{238} \mathrm{U}\right)$ values like those we measured in Kolbeinsey Ridge lavas (Table 3) with two-porosity melting models. Our models do not explicitly consider melt transport time in high-porosity channels, as others have modeled (Jull et al., 2002; LundSTROM, 2000; SIMS et al., 2002; SiMS et al., 1999b; TEPLEY et al., 2004). Taking into account the time of disequilibrium transport with variable melt productivities may better reproduce our Kolbeinsey $\left({ }^{231} \mathrm{~Pa} /{ }^{235} \mathrm{U}\right)$ values, since such a calculation does not allow for preservation of such large ${ }^{231} \mathrm{~Pa}$ excesses in the melts. 


\subsubsection{Global ${ }^{230} \mathrm{Th}^{238} \mathrm{U}$ Disequilibria, Spreading Rates, and Axial Depth}

It is relatively straightforward to generate the large and relatively uniform ${ }^{230} \mathrm{Th}$ excesses seen in our Kolbeinsey data set; we next consider the data in a global context, and look at how Kolbeinsey Ridge plays into global models for MORB geochemistry. Global studies (Brodholt and BATIZA, 1989; DicK et al., 1984; KLEIN and LANGMUIR, 1987; LANGMUIR et al., 1992) have shown that variations in the major- and trace element compositions of MORB are related to ridge depth and crustal thickness, suggesting systematic variations in the temperature and therefore the degree and depth of melting beneath large areas of the global ridge system. Klein and Langmuir (1987) proposed that the low $\mathrm{Na}_{8}$ ( $\mathrm{Na}$ contents corrected for low-pressure crystal fractionation to a $\mathrm{MgO}$ content of $8 \%$ ) and anomalously thick crust typical of shallow ridges are the result of large degrees of mantle melting. Based on experimental observations, they also interpreted the high $\mathrm{Fe}_{8}$ of lavas from these ridges as an indication of deep melting. The ridge with the most extreme chemical characteristics (shallowest axis, lowest $\mathrm{Na}_{8}$, highest $\mathrm{Fe}_{8}$ ) studied by Klein and Langmuir (1987) was the Kolbeinsey Ridge.

Despite the large degrees of melting postulated from major element calculations, Klein and Langmuir (1987) and Langmuir et al. (1992) observed that the trace element ratios for Kolbeinsey Ridge lavas require small degrees of melting. They attributed this to a heterogeneous mantle source, something we have shown is not supported by variations in radiogenic isotope ratios or melting models. Mertz et al. (1991) and Mertz and Haase (1997) also showed that the most isotopically enriched samples (i.e. high ${ }^{87} \mathrm{Sr} /{ }^{86} \mathrm{Sr}$ and low ${ }^{143} \mathrm{Nd} /{ }^{144} \mathrm{Nd}$ ) have the most depleted incompatible element signatures, which is inconsistent with the hypothesis that source variations control highly incompatible element abundances and ratios at the Kolbeinsey Ridge. In Section 4.3.1 and 4.3.2 we determined that Kolbeinsey MORB have large ${ }^{230} \mathrm{Th}$ excesses, indicating a long melt column that initiates in the garnet stability field and can generate the deep melting and high melt fraction $(\mathrm{F})$ signatures observed in the major elements of the lavas $\left(\mathrm{Fe}_{8}, \mathrm{Na}_{8}\right.$, $\left.(\mathrm{Ca} / \mathrm{Al})_{8}\right)$, but that trace elements indicate a relatively young mantle source. 
Bourdon et al. (1996b) have shown that on a global scale there is also a broad negative correlation between the amount of ${ }^{238} \mathrm{U}^{230} \mathrm{Th}$ disequilibrium and the axial ridge depth of MORB. Their interpretation was that this correlation reflects mantle temperature variations beneath the ridge: hotter mantle intersects its solidus at a greater depth, resulting in a longer melt column and more melt generation, which in turn generates thicker crust, a shallower ridge, and larger ${ }^{230} \mathrm{Th}$ excess (because of the longer melt column in the garnet stability field). Bourdon et al. (1996b) did not examine shallow ridges, but their model would predict that shallow ridges like the Kolbeinsey Ridge should have the highest ${ }^{230} \mathrm{Th}$ excesses.

However, although we have constrained the range of $\left({ }^{230} \mathrm{Th} /{ }^{238} \mathrm{U}\right)$ values for Kolbeinsey Ridge to be relatively narrow, we note that Figure 10 demonstrates a great deal of global variability. Peate et al. (2001) measured a large range of U-Th disequilibria for the Reykjanes Ridge, which they attribute to the influence of heterogeneous mantle sources and the upwelling effect of the Iceland plume. However, due to polybaric melt effects and to the likelihood of low-porosity zones that efficiently extract deep melts, only the maximum $\left({ }^{230} \mathrm{Th} /{ }^{238} \mathrm{U}\right)$ for a ridge segment should reflect the mantle temperature effect described by Bourdon et al. (1996b), because only the melts with the most ${ }^{230} \mathrm{Th}$ excess reflect the deepest part of the melting column. Since mixing in magma chambers is variable beneath MOR, masking variability at some locations, mean $\left({ }^{230} \mathrm{Th} /{ }^{238} \mathrm{U}\right)$ is probably a more accurate method for comparing global ridges with different spreading rates. Figure 10 shows that broadly, ridge-averaged $\left({ }^{230} \mathrm{Th} /{ }^{238} \mathrm{U}\right)$ for the global MORB data set support the observations of Bourdon et al. (1996b). 


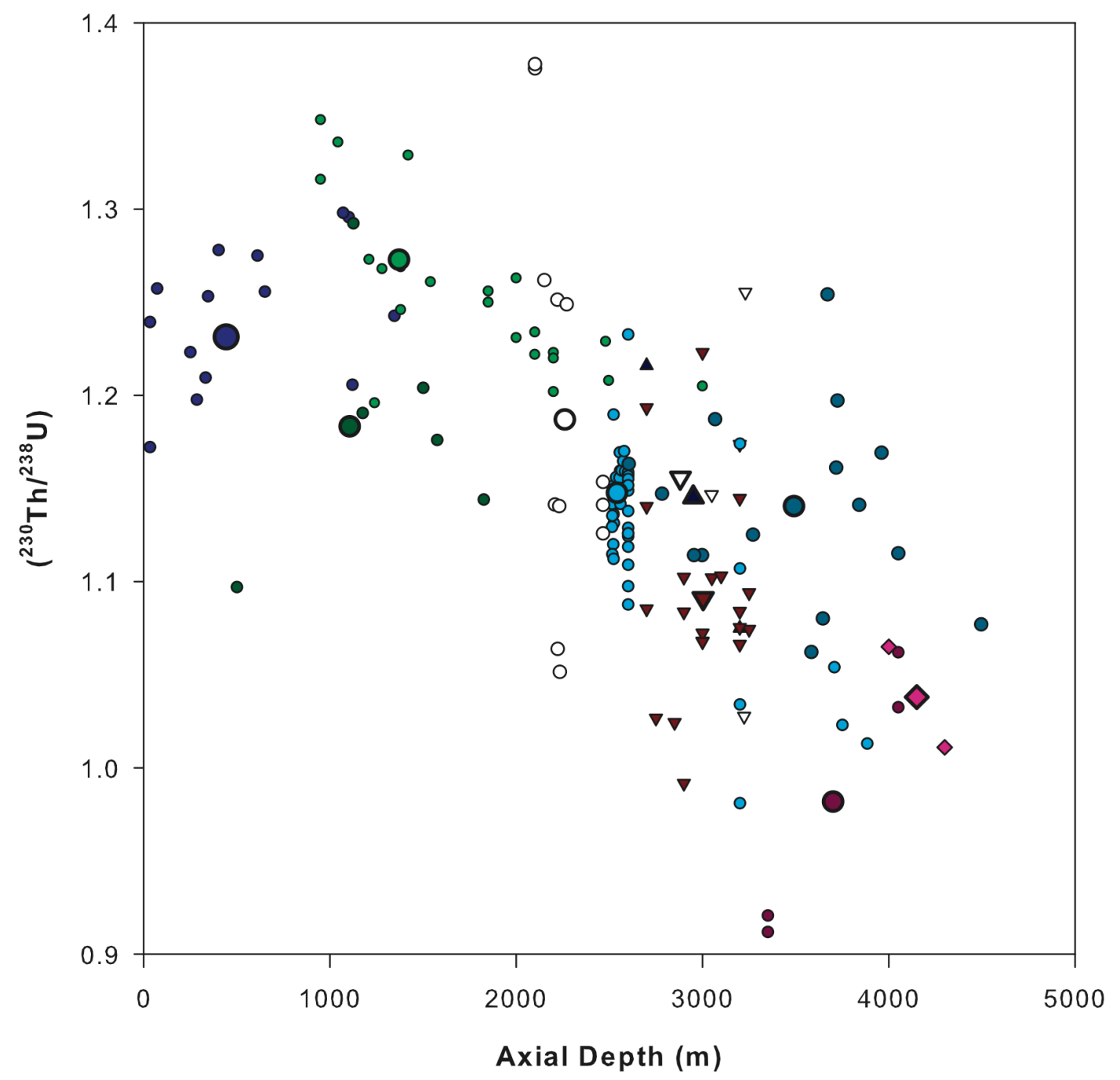

\begin{tabular}{|ll|}
\hline Kolbeinsey Ridge \\
O & $9-10$ N EPR/Siquieros \\
O & Juan de Fuca \\
O & $37-40$ N MAR \\
0 & $29-30 N$ MAR \\
0 & AAD \\
$\Delta$ & $22-23$ EPR \\
$\nabla$ & Tamayo \\
0 & Reykjanes \\
$\nabla$ & Gorda \\
$\mathbf{O}$ & 33S MAR \\
\hline
\end{tabular}

Figure 10. Axial ridge depth vs. MORB $\left({ }^{230} \mathrm{Th} /{ }^{238} \mathrm{U}\right)$ for global ridge segments, after Bourdon et al. (1996b), Lundstrom et al. (2003) and references therein. Kolbeinsey Ridge data are from this study. We only show Kolbeinsey Ridge samples with measured $\left({ }^{234} U /{ }^{238} U\right)$ in equilibrium (Table 2, Figure 4). 


\subsection{CONCLUSIONS}

1. The slow-spreading Kolbeinsey Ridge MORB data form a nearly horizontal trend (slope $=0.05)$ on a plot of $\left({ }^{230} \mathrm{Th} /{ }^{232} \mathrm{Th}\right)$ vs. $\left({ }^{238} \mathrm{U} /{ }^{232} \mathrm{Th}\right.$ ). This slope would appear to be consistent with a model relating the slopes of ridge segments to their solid mantle upwelling rates. However, such a model requires mixing of enriched and depleted sources to explain the slope dependence, and Kolbeinsey R. radiogenic isotope data do not correlate with ${ }^{238} \mathrm{U}^{230} \mathrm{Th}$ disequilibria, precluding heterogeneous source control. These disequilibria also fail to correlate with trace element abundances or ratios, also precluding a simple melting process. Correlation with $\left({ }^{234} \mathrm{U} /{ }^{238} \mathrm{U}\right)$ instead suggests that ${ }^{238} \mathrm{U}$ excess samples result from shallow crustal alteration in the presence of seawater. Unaltered Kolbeinsey MORB have universally high ${ }^{230} \mathrm{Th}$ excesses, indicating a deep, long melting column that can produce both the large degrees of melting indicated by major element systematics and the shallow ridge axis.

2. Trace element ratios and concentrations are more depleted than predicted by melting models. Most Kolbeinsey $\alpha_{\mathrm{Sm}-\mathrm{Nd}}$ ratios are also greater than one, which cannot be generated by simple one-stage melting of a single-age long-lived source. We suggest that a young, depleted source associated with the young Kolbeinsey Ridge can account for this signature.

3. Kolbeinsey Ridge $\left.{ }^{230} \mathrm{Th} /{ }^{238} \mathrm{U}\right)$ corroborate global observations by Bourdon et al. (1996b) that mantle temperature determines mean ridge $\left({ }^{230} \mathrm{Th} /{ }^{238} \mathrm{U}\right)$. The shallow ridge axis and thick crust on the Kolbeinsey Ridge predict a hot mantle and deep melt column, which is supported by our measured ${ }^{230} \mathrm{Th}$ excesses.

We thus present a working model for the Kolbeinsey Ridge MORB, which derive from a depleted, relatively young mantle source (as indicated by $\alpha_{\mathrm{Sm}-\mathrm{Nd}}$ ). These basalts are the result of melting in a long melt column that produces large ${ }^{230} \mathrm{Th}$ excesses and the 
thick crust and shallow Kolbeinsey Ridge axis. Shallow alteration is likely responsible for producing samples with low $\left({ }^{230} \mathrm{Th} /{ }^{238} \mathrm{U}\right)$.

\section{References}

Andres, M., Blichert-Toft, J., and Schilling, J. G., 2004. Nature of the depleted upper mantle beneath the Atlantic: evidence from Hf isotopes in normal mid-ocean ridge basalts from 79 degrees N to 55 degrees S. Earth Planet Sc Lett 225, 89103.

Ball, L., Sims, K. W. W., and Schwieters, J., 2008. Measurement of U-234/U-238 and Th-230/Th-232 in volcanic rocks using the Neptune MC-ICP-MS. Journal of Analytical Atomic Spectrometry 23, 173-180.

Baumann, K. H., Lackschewitz, K. S., Erlenkeuser, H., Henrich, R., and Junger, B., 1993. Late Quaternary Calcium-Carbonate Sedimentation and Terrigenous Input Along the East Greenland Continental-Margin. Mar Geol 114, 13-36.

Beattie, P., 1993a. The Generation of Uranium Series Disequilibria by Partial Melting of Spinel Peridotite - Constraints from Partitioning Studies. Earth Planet Sc Lett 117, 379-391.

Beattie, P., 1993b. Uranium Thorium Disequilibria and Partitioning on Melting of Garnet Peridotite. Nature 363, 63-65.

Blichert-Toft, J., 2001. On the Lu-Hf isotope geochemistry of silicate rocks. Geostandards Newsletter-the Journal of Geostandards and Geoanalysis 25, 4156.

Blichert-Toft, J., Agranier, A., Andres, M., Kingsley, R., Schilling, J. G., and Albarede, F., 2005. Geochemical segmentation of the Mid-Atlantic Ridge north of Iceland and ridge-hot spot interaction in the North Atlantic. Geochem Geophy Geosy 6, - .

Blundy, J. D. and Wood, B. J., 2003. Mineral-melt partitioning of uranium, thorium, and their daughters, Reviews in Mineralogy.

Bourdon, B., Joron, J. L., Claude-Ivanaj, C., and Allegre, C. J., 1998. U-Th-Pa-Ra systematics for the Grande Comore volcanics: melting processes in an upwelling plume. Earth Planet Sc Lett 164, 119-133.

Bourdon, B., Langmuir, C. H., and Zindler, A., 1996a. Ridge-hotspot interaction along the Mid-Atlantic Ridge between 37 degrees 30' and 40 degrees 30 'N: The U-Th disequilibrium evidence. Earth Planet Sc Lett 142, 175-189.

Bourdon, B., Ribe, N. M., Stracke, A., Saal, A. E., and Turner, S. P., 2006. Insights into the dynamics of mantle plumes from uranium-series geochemistry. Nature 444, 713-717.

Bourdon, B., Zindler, A., Elliott, T., and Langmuir, C. H., 1996b. Constraints on mantle melting at mid-ocean ridges from global U-238-Th-230 disequilibrium data. Nature 384, 231-235. 
Brandsdottir, B., Richter, B., Riedel, C., Dahm, T., Helgadottir, G., Kjartansson, E., Detrick, R., Magnusson, A., Asgrimsson, A. L., Palsson, B. H., Karson, J., Saemundsson, K., Mayer, L. A., Calder, B., and Driscoll, N. W., 2004. Tectonic details of the Tjornes fracture zone, an onshore-offshore ridge-transform in NIceland. Eos Trans. American Geophys. Union 85, Abstract T41A-1172.

Braun, M. G., Hirth, G., and Parmentier, E. M., 2000. The effects of deep damp melting on mantle flow and melt generation beneath mid-ocean ridges. Earth Planet Sc Lett 176, 339-356.

Brodholt, J. P. and Batiza, R., 1989. Global Systematics of Unaveraged Mid-Ocean Ridge Basalt Compositions - Comment. J Geophys Res-Solid 94, 4231-4239.

Claude-Ivanaj, C., Bourdon, B., and Allegre, C. J., 1998. Ra-Th-Sr isotope systematics in Grande Comore Island: a case study of plume-lithosphere interaction. Earth Planet Sc Lett 164, 99-117.

Claude-Ivanaj, C., Joron, J. L., and Allegre, C. J., 2001. U-238-Th-230-Ra-226 fractionation in historical lavas from the Azores: long-lived source heterogeneity vs. metasomatism fingerprints. Chem Geol 176, 295-310.

Cohen, R. S., Evensen, N. M., Hamilton, P. J., and Onions, R. K., 1980. U-Pb, Sm-Nd and Rb-Sr Systematics of Mid-Ocean Ridge Basalt Glasses. Nature 283, 149-153.

Condomines, M., Morand, P., Allegre, C. J., and Sigvaldason, G., 1981. Th-230-U-238 Disequilibria in Historical Lavas from Iceland. Earth Planet Sc Lett 55, 393-406.

Devey, C. W., Garbeschonberg, C. D., Stoffers, P., Chauvel, C., and Mertz, D. F., 1994. Geochemical Effects of Dynamic Melting beneath Ridges - Reconciling Major and Trace-Element Variations in Kolbeinsey (and Global) Midocean Ridge Basalt. J Geophys Res-Sol Ea 99, 9077-9095.

Dick, H. J. B., Fisher, R. L., and Bryan, W. B., 1984. Mineralogic Variability of the Uppermost Mantle Along Mid-Ocean Ridges. Earth Planet Sc Lett 69, 88-106.

Draper, D. S. and van Westrenen, W., 2007. Quantifying garnet-melt trace element partitioning using lattice-strain theory: assessment of statistically significant controls and a new predictive model. Contrib Mineral Petr.

Dupre, B. and Allegre, C. J., 1980. Pb-Sr-Nd Isotopic Correlation and the Chemistry of the North-Atlantic Mantle. Nature 286, 17-22.

Elkins, L. J., Gaetani, G. A., and Sims, K. W. W., 2008. Partitioning of U and Th during garnet pyroxenite partial melting: Constraints on the source of alkaline ocean island basalts. Earth Planet Sc Lett 265, 270-286.

Fairbanks, R. G., 1989. A 17,000-Year Glacio-Eustatic Sea-Level Record - Influence of Glacial Melting Rates on the Younger Dryas Event and Deep-Ocean Circulation. Nature 342, 637-642.

Faure, G. and Mensing, T. M., 2005. Isotopes: Principles and Applications. John Wiley and Sons, Inc., Hoboken, New Jersey.

Frujiter, C., Elliott, T., and Schlager, W., 2000. Mass-spectrometric 234U-230Th ages from the Key Largo Formation, Florida Keys, United States: Constraints on diagenetic age disturbance. Geological Society of America Bulletin 112, 267-277.

Furman, T., Frey, F. A., and Park, K. H., 1991. Chemical Constraints on the Petrogenesis of Mildly Alkaline Lavas from Vestmannaeyjar, Iceland - the Eldfell (1973) and Surtsey (1963-1967) Eruptions. Contrib Mineral Petr 109, 19-37. 
Glass, J. B., Cooper, K. M., Alt, J. C., Elliott, T., and Teagle, D. A., 2005. Recent Alteration of 15-Ma Oceanic Crust, ODP Site 1256, Leg 206. Eos Trans. American Geophys. Union 86, V43B-1568.

Goldstein, S. J., Murrell, M. T., and Jackecky, D. R., 1989. Th and U isotopic systematics of basalts from the Juan de Fuca and Gorda Ridges by mass spectrometry. Earth Planet Sc Lett 96, 134-146.

Goldstein, S. J., Murrell, M. T., Janecky, D. R., Delaney, J. R., and Clague, D. A., 1992. Geochronology and Petrogenesis of Morb from the Juan-De-Fuca and Gorda Ridges by U-238 Th-230 Disequilibrium. Earth Planet Sc Lett 109, 255-272.

Goldstein, S. J., Murrell, M. T., and Williams, R. W., 1993. Pa-231 and Th-230 Chronology of Midocean Ridge Basalts. Earth Planet Sc Lett 115, 151-159.

Haase, K. M., Devey, C. W., and Wieneke, M., 2003. Magmatic processes and mantle heterogeneity beneath the slow-spreading northern Kolbeinsey Ridge segment, North Atlantic. Contrib Mineral Petr 144, 428-448.

Hanan, B. B., Blichert-Toft, J., Kingsley, R., and Schilling, J. G., 2000. Depleted Iceland mantle plume geochemical signature: artifact of multicomponent mixing? Geochem Geophy Geosy 1.

Hardarson, B. S. and Fitton, J. G., 1997. Mechanisms of crustal accretion in Iceland. Geology 25, 1043-1046.

Hards, V. L., Kempton, P. D., and Thompson, R. N., 1995. The Heterogeneous Iceland Plume - New Insights from the Alkaline Basalts of the Snaefell Volcanic Center. $J$ Geol Soc London 152, 1003-1009.

Hart, S. R., Hauri, E. H., Oschmann, L. A., and Whitehead, J. A., 1992. Mantle Plumes and Entrainment - Isotopic Evidence. Science 256, 517-520.

Hauri, E. H., Wagner, T. P., and Grove, T. L., 1994. Experimental and Natural Partitioning of Th, U, Pb and Other Trace-Elements between Garnet, Clinopyroxene and Basaltic Melts. Chem Geol 117, 149-166.

Hemond, C., Arndt, N. T., Lichtenstein, U., Hofmann, A. W., Oskarsson, N., and Steinthorsson, S., 1993. The Heterogeneous Iceland Plume - Nd-Sr-O Isotopes and Trace-Element Constraints. J Geophys Res-Sol Ea 98, 15833-15850.

Henderson, G. M., Cohen, A. S., and Onions, R. K., 1993. U-234/U-238 Ratios and Th230 Ages for Hateruma Atoll Corals - Implications for Coral Diagenesis and Seawater U-234/U-238 Ratios. Earth Planet Sc Lett 115, 65-73.

Hilton, D. R., Thirlwall, M. F., Taylor, R. N., Murton, B. J., and Nichols, A., 2000. Controls on magmatic degassing along the Reykjanes Ridge with implications for the helium paradox. Earth Planet Sc Lett 183, 43-50.

Hirschmann, M. M., Asimow, P. D., Ghiorso, M. S., and Stolper, E. M., 1999. Calculation of peridotite partial melting from thermodynamic models of minerals and melts. III. Controls on isobaric melt production and the effect of water on melt production. J Petrol 40, 831-851.

Hirschmann, M. M., Kogiso, T., Baker, M. B., and Stolper, E. M., 2003. Alkalic magmas generated by partial melting of garnet pyroxenite. Geology 31, 481-484.

Hirschmann, M. M. and Stolper, E. M., 1996. A possible role for garnet pyroxenite in the origin of the "garnet signature" in MORB. Contrib Mineral Petr 124, 185-208.

Hoffmann, D. L., Prytulak, J., Richards, D. A., Elliott, T., Coath, C. D., Smart, P. L., and Scholz, D., 2007. Procedures for accurate $\mathrm{U}$ and $\mathrm{Th}$ isotope measurements by 
high precision MC-ICPMS. International Journal of Mass Spectrometry 264, 97109.

Hooft, E. E. E., Brandsdottir, B., Mjelde, R., Shimamura, H., and Murai, Y., 2006. Asymmetric plume-ridge interaction around Iceland: The Kolbeinsey Ridge Iceland Seismic Experiment. Geochem Geophy Geosy 7, -.

Jakobsson, M., Macnab, R., Mayer, L., Anderson, R., Edwards, M., Hatzky, J., Schenke, H. W., and Johnson, P., 2008. An improved bathymetric portrayal of the Arctic Ocean: Implications for ocean modeling and geological, geophysical and oceanographic analyses. Geophysical Research Letters 35, -.

Jull, M., Kelemen, P. B., and Sims, K., 2002. Consequences of diffuse and channelled porous melt migration on uranium series disequilibria. Geochim Cosmochim Ac 66, 4133-4148.

Kelemen, P. B. and Dick, H. J. B., 1995. Focused Melt Flow and Localized Deformation in the Upper-Mantle - Juxtaposition of Replacive Dunite and Ductile Shear Zones in the Josephine Peridotite, Sw Oregon. J Geophys Res-Sol Ea 100, 423-438.

Kelemen, P. B., Hanghoj, K., and Greene, A. R., 2004. One View of the Geochemistry of Subduction-related Magmatic Arcs, with an Emphasis on Primitive Andesite and Lower Crust. In: Holland, H. D. and Turekian, K. K. Eds.)Treatise on Geochemistry. Elsevier, Amsterdam.

Kelemen, P. B., Hirth, G., Shimizu, N., Spiegelman, M., and Dick, H. J. B., 1997. A review of melt migration processes in the adiabatically upwelling mantle beneath oceanic spreading ridges. Philosophical Transactions of the Royal Society of London Series a-Mathematical Physical and Engineering Sciences 355, 283-318.

Klein, E. M. and Langmuir, C. H., 1987. Global Correlations of Ocean Ridge Basalt Chemistry with Axial Depth and Crustal Thickness. J Geophys Res-Solid 92, 8089-8115.

Kodaira, S., Mjelde, R., Gunnarsson, K., Shiobara, H., and Shimamura, H., 1997. Crustal structure of the Kolbeinsey Ridge, North Atlantic, obtained by use of ocean bottom seismographs. J Geophys Res-Sol Ea 102, 3131-3151.

Kogiso, T., Hirschmann, M. M., and Frost, D. J., 2003. High-pressure partial melting of garnet pyroxenite: possible mafic lithologies in the source of ocean island basalts. Earth Planet Sc Lett 216, 603-617.

Kogiso, T., Hirschmann, M. M., and Pertermann, M., 2004. High-pressure partial melting of mafic lithologies in the mantle. J Petrol 45, 2407-2422.

Kokfelt, T. F., Hoernle, K., and Hauff, F., 2003. Upwelling and melting of the Iceland plume from radial variation of U-238-Th-230 disequilibria in postglacial volcanic rocks. Earth Planet Sc Lett 214, 167-186.

Krolikowska-Ciaglo, S., Deyhle, A., Hauff, F., and Hoernle, K., 2007. Boron isotope geochemistry and $\mathrm{U}-\mathrm{Pb}$ systematics of altered MORB from the Australian Antarctic Discordance (ODP Leg 187). Chemical Geology 242, 458-472.

Ku, T. L., Knauss, K. G., and Mathieu, G. G., 1977. Uranium in Open Ocean Concentration and Isotopic Composition. Deep-Sea Research 24, 1005-1017.

La Tourette, T. Z. and Burnett, D. S., 1992. Experimental determination of U-partitioning and Th-partitioning between cpx and natural and synthetic basaltic liquid. Earth Planet Sc Lett 110, 227-244. 
La Tourette, T. Z., Kennedy, A. K., and Wasserburg, G. J., 1993. Thorium-uranium fractionation by garnet: Evidence for a deep source and rapid rise of oceanic basalts. Science 261, 729-742.

Lackschewitz, K. S., Wallrabeadams, H. J., and Garbeschonberg, D., 1994. Geochemistry of Surface Sediments from the Midoceanic Kolbeinsey Ridge, North of Iceland. Mar Geol 121, 105-119.

Landwehr, D., Blundy, J., Chamorro-Perez, E. M., Hill, E., and Wood, B., 2001. U-series disequilibria generated by partial melting of spinel lherzolite. Earth Planet Sc Lett 188, 329-348.

Langmuir, C., Klein, E. M., and Plank, T., 1992. Petrological systematics of mid-ocean ridge basalts: constraints on melt generation beneath ocean ridges, Mantle Flow and Melt Generation at Mid-Ocean Ridges.

Lundstrom, C., 2000. Models of U-series disequilibria generation in MORB: the effects of two scales of melt porosity. Phys Earth Planet In 121, 189-204.

Lundstrom, C. C., 2003. Uranium-series disequilibria in mid-ocean ridge basalts: Observations and models of basalt genesis. Rev Mineral Geochem 52, 175-214.

Lundstrom, C. C., Sampson, D. E., Perfit, M. R., Gill, J., and Williams, Q., 1999. Insights into mid-ocean ridge basalt petrogenesis: U-series disequilibria from the Siqueiros Transform, Lamont Seamounts, and East Pacific Rise. J Geophys Res-Sol Ea 104, 13035-13048.

Lundstrom, C. C., Shaw, H. F., Ryerson, F. J., Phinney, D. L., Gill, J. B., and Williams, Q., 1994. Compositional Controls on the Partitioning of U, Th, Ba, Pb, Sr and Zr between Clinopyroxene and Haplobasaltic Melts - Implications for Uranium Series Disequilibria in Basalts. Earth Planet Sc Lett 128, 407-423.

Lundstrom, C. C., Williams, Q., and Gill, J. B., 1998. Investigating solid mantle upwelling rates beneath mid-ocean ridges using U-series disequilibria, 1: a global approach. Earth Planet Sc Lett 157, 151-165.

Mckenzie, D., 1985. Th-230-U-238 Disequilibrium and the Melting Processes beneath Ridge Axes. Earth Planet Sc Lett 72, 149-157.

Mertz, D. F., Devey, C. W., Todt, W., Stoffers, P., and Hofmann, A. W., 1991. Sr-Nd-Pb Isotope Evidence against Plume Asthenosphere Mixing North of Iceland. Earth Planet Sc Lett 107, 243-255.

Mertz, D. F. and Haase, K. M., 1997. The radiogenic isotope composition of the highlatitude North Atlantic mantle. Geology 25, 411-414.

Mertz, D. F., Sharp, W. D., and Haase, K. M., 2004. Volcanism on the Eggvin Bank (Central Norwegian-Greenland Sea, latitude similar to 71 degrees N): age, source, and relationship to the Iceland and putative Jan Mayen plumes. J Geodyn 38, 5783.

Michael, P., 1995. Regionally Distinctive Sources of Depleted Morb - Evidence from Trace-Elements and H2o. Earth Planet Sc Lett 131, 301-320.

Michael, P. J., Chase, R. L., and Allan, J. F., 1989. Petrologic and Geologic Variations Along the Southern Explorer Ridge, Northeast Pacific-Ocean. J Geophys ResSolid 94, 13895-13918.

Mjelde, R., Raum, T., Breivik, A. J., and Faleide, J. I., 2008. Crustal transect across the North Atlantic. Mar Geophys Res 29, 73-87. 
Mosar, J., Lewis, G., and Torsvik, T. H., 2002. North Atlantic sea-floor spreading rates: implications for the Tertiary development of inversion structures of the Norwegian-Greenland Sea. J Geol Soc London 159, 503-515.

Murton, B. J., Taylor, R. N., and Thirlwall, M. F., 2002. Plume-ridge interaction: A geochemical perspective from the Reykjanes Ridge. Journal of Petrology 43, 1987-2012.

Neumann, E. R. and Schilling, J. G., 1984. Petrology of Basalts from the MohnsKnipovich Ridge - the Norwegian-Greenland Sea. Contrib Mineral Petr 85, 209223.

O'Nions, R. K. and Pankhurs.Rj, 1973. Secular Variation in Sr-Isotope Composition of Icelandic Volcanic-Rocks. Earth Planet Sc Lett 21, 13-21.

Peate, D. W., Hawkesworth, C. J., van Calsteren, P. W., Taylor, R. N., and Murton, B. J., 2001. U-238-Th-230 constraints on mantle upwelling and plume-ridge interaction along the Reykjanes Ridge. Earth Planet Sc Lett 187, 259-272.

Pertermann, M. and Hirschmann, M. M., 2003. Anhydrous partial melting experiments on MORB-like eclogite: Phase relations, phase compositions and mineral-melt partitioning of major elements at 2-3 GPa. J Petrol 44, 2173-2201.

Pertermann, M., Hirschmann, M. M., Hametner, K., Gunther, D., and Schmidt, M. W., 2004. Experimental determination of trace element partitioning between garnet and silica-rich liquid during anhydrous partial melting of MORB-like eclogite. Geochem Geophy Geosy 5, - .

Pickett, D. A. and Murrell, M. T., 1997. Observations of $\left({ }^{231} \mathrm{~Pa}\right) /\left({ }^{235} \mathrm{U}\right)$ disequilibrium in volcanic rocks. Earth Planet Sc Lett 148, 259-271.

Pietruszka, A. J., Rubin, K. H., and Garcia, M. O., 2001. Ra-226-Th-230-U-238 disequilibria of historical Kilauea lavas (1790-1982) and the dynamics of mantle melting within the Hawaiian plume. Earth Planet Sc Lett 186, 15-31.

Poreda, R., Schilling, J. G., and Craig, H., 1986. Helium and Hydrogen Isotopes in Ocean-Ridge Basalts North and South of Iceland. Earth Planet Sc Lett 78, 1-17.

Prytulak, J., Elliott, T., Hoffmann, D. L., and Coath, C. D., 2008. Assessment of USGS BCR-2 as a reference material for silicate rock u-pa disequilibrium measurements. Geostand Geoanal Res 32, 55-63.

Regelous, M., Turner, S. P., Elliott, T. R., Rostami, K., and Hawkesworth, C. J., 2004. Measurement of femtogram quantities of protactinium in silicate rock samples by multicollector inductively coupled plasma mass spectrometry. Analytical Chemistry 76, 3584-3589.

Robinson, L. F., Henderson, G. M., Hall, L., and Matthews, I., 2004. Climatic control of riverine and Seawater uranium-isotope ratios. Science 305, 851-854.

Salters, V. J. M. and Longhi, J., 1999. Trace element partitioning during the initial stages of melting beneath mid-ocean ridges. Earth Planet Sc Lett 166, 15-30.

Salters, V. J. M., Longhi, J. E., and Bizimis, M., 2002. Near mantle solidus trace element partitioning at pressures up to 3.4 GPa. Geochem Geophy Geosy 3, -.

Salters, V. J. M. and White, W. M., 1998. Hf isotope constraints on mantle evolution. Chem Geol 145, 447-460.

Schilling, J. G., 1975. Rare-Earth Variations across Normal-Segments of Reykjanes Ridge, 60degrees-53degreesn N, Mid-Atlantic Ridge, 29degreess S, and East 
Pacific Rise, 2degrees-19degreess S, and Evidence on Composition of Underlying Low-Velocity Layer. J Geophys Res 80, 1459-1473.

Schilling, J. G., Kingsley, R., Fontignie, D., Poreda, R., and Xue, S., 1999. Dispersion of the Jan Mayen and Iceland mantle plumes in the Arctic: A He-Pb-Nd-Sr isotope tracer study of basalts from the Kolbeinsey, Mohns, and Knipovich Ridges. $J$ Geophys Res-Sol Ea 104, 10543-10569.

Schilling, J. G., Zajac, M., Evans, R., Johnston, T., White, W., Devine, J. D., and Kingsley, R., 1983. Petrologic and Geochemical Variations Along the MidAtlantic Ridge from 29-Degrees-N to 73-Degrees-N. Am J Sci 283, 510-586.

Sigmarsson, O., Carn, S., and Carracedo, J. C., 1998. Systematics of U-series nuclides in primitive lavas from the 1730-36 eruption on Lanzarote, Canary Islands, and implications for the role of garnet pyroxenites during oceanic basalt formations. Earth Planet Sc Lett 162, 137-151.

Sigurdsson, H., 1981. 1st-Order Major Element Variation in Basalt Glasses from the Mid-Atlantic Ridge - 29-Degrees-N to 73-Degrees-N. J Geophys Res 86, 9483 9502.

Sims, K. W. W., Blichert-Toft, J., Fornari, D. J., Perfit, M. R., Goldstein, S. J., Johnson, P., DePaolo, D. J., Hart, S. R., Murrell, P. J., Michael, P. J., Layne, G. D., and Ball, L. A., 2003. Aberrant youth: Chemical and isotopic constraints on the origin of off-axis lavas from the East Pacific Rise, 9 degrees-10 degrees N. Geochem Geophy Geosy 4, - .

Sims, K. W. W., DePaolo, D. J., Murrell, M. T., Baldridge, W. S., Goldstein, S., Clague, D., and Jull, M., 1999a. Porosity of the melting zone and variations in the solid mantle upwelling rate beneath Hawaii: Inferences from U-238-Th-230-Ra-226 and U-235-Pa-231 disequilibria. Geochim Cosmochim Ac 63, 4119-4138.

Sims, K. W. W., Depaolo, D. J., Murrell, M. T., Baldridge, W. S., Goldstein, S. J., and Clague, D. A., 1995. Mechanisms of Magma Generation beneath Hawaii and Midocean Ridges - Uranium/Thorium and Samarium/Neodymium Isotopic Evidence. Science 267, 508-512.

Sims, K. W. W., Gill, J. B., Dosseto, A., Hoffmann, D. L., Lundstrom, C. C., Williams, R. W., Ball, L., Tollstrup, D., Turner, S., Prytulak, J., Glessner, J. J. G., Standish, J. J., and Elliott, T., 2008a. An inter-laboratory assessment of the thorium isotopic composition of synthetic and rock reference materials. Geostand Geoanal Res 32, 65-91.

Sims, K. W. W., Goldstein, S. J., Blichert-Toft, J., Perfit, M. R., Kelemen, P., Fornari, D. J., Michael, P., Murrell, M. T., Hart, S. R., DePaolo, D. J., Layne, G., Ball, L., Jull, M., and Bender, J., 2002. Chemical and isotopic constraints on the generation and transport of magma beneath the East Pacific Rise. Geochim Cosmochim Ac 66, 3481-3504.

Sims, K. W. W. and Hart, S. R., 2006. Comparison of Th, Sr, Nd and Pb isotopes in oceanic basalts: Implications for mantle heterogeneity and magma genesis. Earth Planet Sc Lett 245, 743-761.

Sims, K. W. W., Hart, S. R., Reagan, M. K., Blusztajn, J., Staudigel, H., Sohn, R. A., Layne, G. D., and Ball, L. A., 2008b. 238U-Th-230-Ra-226-Pb-210-Po-210, Th232-Ra-228, and U-235-Pa-231 constraints on the ages and petrogenesis of Vailulu'u and Malumalu Lavas, Samoa. Geochem Geophy Geosy 9, -. 
Sims, K. W. W., Jull, M., and Kelemen, P., 1999b. U-series disequilibria and melt transport in the mantle beneath mid-ocean ridges. Transactions-American Geophysical Union, V22D.

Smith, W. H. F. and Sandwell, D. T., 1997. Global sea floor topography from satellite altimetry and ship depth soundings. Science 277, 1956-1962.

Spiegelman, M., 2000. UserCalc: a web-based uranium series calculator for magma migration problems. Geochem Geophy Geosy 1, 11.

Spiegelman, M. and Elliott, T., 1993. Consequences of Melt Transport for Uranium Series Disequilibrium in Young Lavas. Earth Planet Sc Lett 118, 1-20.

Spiegelman, M. and Kelemen, P. B., 2003. Extreme chemical variability as a consequence of channelized melt transport. Geochem Geophy Geosy 4, -.

Stecher, O., Carlson, R. W., and Gunnarsson, B., 1999. Torfajokull: a radiogenic endmember of the Iceland Pb-isotopic array. Earth Planet Sc Lett 165, 117-127.

Stracke, A., Bourdon, B., and McKenzie, D., 2006. Melt extraction in the Earth's mantle: Constraints from U-Th-Pa-Ra studies in oceanic basalts. Earth Planet Sc Lett 244, 97-112.

Stracke, A., Zindler, A., Salters, V. J. M., McKenzie, D., Blichert-Toft, J., Albarede, F., and Gronvold, K., 2003a. Theistareykir revisited. Geochem Geophy Geosy 4, -.

Stracke, A., Zindler, A., Salters, V. J. M., McKenzie, D., and Gronvold, K., 2003b. The dynamics of melting beneath Theistareykir, northern Iceland. Geochem Geophy Geosy 4, - .

Sturm, M. E., Goldstein, S. J., Klein, E. M., Karson, J. A., and Murrell, M. T., 2000. Uranium-series age constraints on lavas from the axial valley of the Mid-Atlantic Ridge, MARK area. Earth Planet Sc Lett 181, 61-70.

Sun, S. S. and Jahn, B., 1975. Lead and Strontium Isotopes in Postglacial Basalts from Iceland. Nature 255, 527-530.

Taras, B. D. and Hart, S. R., 1987. Geochemical evolution of the New England seamount chain: Isotopic and trace-element constraints. Chemical Geology 64, 35-54.

Tepley, F. J., Lundstrom, C. C., Sims, K. W. W., and Hekinian, R., 2004. U-series disequilibria in MORB from the Garrett Transform and implications for mantle melting. Earth Planet Sc Lett 223, 79-97.

Thirlwall, M. F., Gee, M. A. M., Taylor, R. N., and Murton, B. J., 2004. Mantle components in Iceland and adjacent ridges investigated using double-spike $\mathrm{Pb}$ isotope ratios. Geochim Cosmochim Ac 68, 361-386.

Todt, W., Cliff, R. A., Hanser, A., and Hofmann, A., 1996. Evaluation of a 202Pb-205Pb double spike for high-precision lead isotope analysis. In: Basu, A. and Hart, S. R. Eds.), Earth Processes Reading the Isotope Code. AGU.

Tronnes, R. G., Planke, S., Sundvoll, B., and Imsland, P., 1999. Recent volcanic rocks from Jan Mayen: Low-degree melt fractions of enriched northeast Atlantic mantle. J Geophys Res-Sol Ea 104, 7153-7168.

Turner, S., Hawkesworth, C., Rogers, N., and King, P., 1997. U-Th isotope disequilibria and ocean island basalt generation in the Azores. Chem Geol 139, 145-164.

Verma, S. P., 1992. Seawater alteration effects on REE, K, Rb, Cs, Sr, U, Th, Pb and Sr$\mathrm{Nd}-\mathrm{Pb}$ isotope systematics of Mid-Ocean Ridge Basalt. Geochemical Journal 26, 159-177. 
Waggoner, D., 1989. An isotopic and trace element study of mantle hterogeneity beneth the Norwegian-Greenland Sea, University of Rhode Island.

White, W. M., Albarede, F., and Telouk, P., 2000. High-precision analysis of Pb isotope ratios using multicollector ICP-MS. Chemical Geology 167, 270-275.

Widom, E., Carlson, R. W., Gill, J. B., and Schmincke, H. U., 1997. Th-Sr-Nd-Pb isotope and trace element evidence for the origin of the Sao Miguel, Azores, enriched mantle source. Chem Geol 140, 49-68.

Williams, R. W. and Gill, J. B., 1989. Effects of Partial Melting on the Uranium Decay Series. Geochim Cosmochim Ac 53, 1607-1619.

Wood, B. J., Blundy, J. D., and Robinson, J. A. C., 1999. The role of clinopyroxene in generating U-series disequilibrium during mantle melting. Geochim Cosmochim Ac 63, 1613-1620.

\section{APPENDIX}

For our batch, fractional, dynamic, and reactive porous flow melting calculations, productivity inputs for peridotite varied during melting in the manner illustrated in Figure 7, with a linear temperature-pressure relationship during upwelling (we assume a solidus slope of $120^{\circ} \mathrm{C} / \mathrm{GPa}$ for all lithologies). Hirschmann et al. (1999) showed that melt productivity at the peridotite solidus is equal to or lower than $0.4 \%$ melting per $\mathrm{km}$, but that in a batch melting regime, productivity increases to as much as $24 \% / \mathrm{GPa}$ by the time of clinopyroxene exhaustion at $\sim 18 \%$ melting. Although productivities are lower for fractional melting, the difference in productivity does not significantly affect our results, so for the sake of simplicity all peridotite melting models use the same productivity variations. We fix partition coefficients for the garnet peridotite and spinel peridotite melting regimes (as well as for other lithologies described below; see Table 4), but mineral modes vary to best reflect expected melting behavior and changes in mineral stability with depth (HIRSCHMANN et al., 1999). Appendix Figure 2 shows how mineral modes vary with depth peridotite (as well as other lithologies considered below). Initial source $\mathrm{U} / \mathrm{Th}$ ratios were chosen to best reproduce the available data, so that initial garnet and spinel peridotite melts had $\left({ }^{238} \mathrm{U} /{ }^{232} \mathrm{Th}\right)=\left({ }^{230} \mathrm{Th} /{ }^{232} \mathrm{Th}\right)=1.25$. In Figure 9 we show binary mixtures of deep, initial garnet peridotite melts $(\mathrm{F} \leq 0.1 \%)$ with shallower melts at $\mathrm{F}=2 \%$ (see Appendix Figure 1 for mechanisms for mixing deep and shallow melts), which is the point at which the largest ${ }^{238} \mathrm{U}$ excess is generated in our melt calculations. 
Batch melting calculations are straightforward, but to vary productivity variations and bulk partition coefficients with depth in fractional, dynamic, and reactive porous flow models requires more sophisticated calculations. In the case of fractional and dynamic melting, we accomplish this with incremental calculations. Our dynamic melt calculation resembles the incremental modeling spreadsheet published by Stracke et al. (2003b), but distance and time increments vary for each of the constant steps in degree of melting (see Figure 7). For reactive porous flow melting calculations, we use our input parameters for F, depth, and partition coefficients (Table 4; Figure 7; Appendix Figure 2) and the program UserCalc, developed by Spiegelman (2000). We use an upwelling rate equal to the half-spreading rate for Kolbeinsey Ridge, which is $9 \mathrm{~mm} / \mathrm{yr}$., and a porosity of $0.5 \%$.

We note that there are other, more complex mechanisms possible for producing and extracting both deep and shallow melts. One such scenario is a single melt column with two porosities of extraction, but in which the deep and shallow melts are the result of wet and dry melt pulses at different depths. This is a scenario where there is a small amount of wet melting at depth that dehydrates the residue, producing $\left({ }^{230} \mathrm{Th} /{ }^{238} \mathrm{U}\right)>1$ in an initial melt. This residue then undergoes a second pulse of melting at shallower depths upon reaching the dry peridotite solidus, producing a melt with ${ }^{238} \mathrm{U}$ excess. These deep and shallow melts variably mix prior to eruption. A reactive porous flow calculation for such a model, where there is a very small pulse of $0.01 \%$ melting very deep $(300 \mathrm{~km})$ and a second pulse initiating at shallower depths in the peridotite stability field, results in nearly identical results to those shown for reactive porous flow calculations in Figure 8 and Figure 9.

The results of dynamic melt calculations are shown in Appendix Figure 3 for a $100 \mathrm{~km}$ garnet peridotite melting column. The dynamic melt has the same productivity variations and varying bulk partition coefficients as used for the batch melt from Section 3.4.2.1, and uses the same upwelling rate and porosity as the reactive porous flow model. The resulting melt composition is so heavily controlled by melts produced at low $\mathrm{F}$ that no ${ }^{238} \mathrm{U}$ excess can be created.

The relative homogeneity of long-lived radiogenic isotopes along the Kolbeinsey Ridge, despite the large variations in $\left({ }^{230} \mathrm{Th} /{ }^{238} \mathrm{U}\right)$, implies that source heterogeneity does not control the Kolbeinsey ${ }^{238} \mathrm{U}_{-}{ }^{230} \mathrm{Th}$ systematics along the horizontal array. This implies 
lithologic homogeneity in the source as well. However, though the scenario is unlikely, it could be argued that Th isotopes alone reflect lithologic heterogeneity. We consider a two-lithology scenario where the garnet-bearing source is a mafic lithology like eclogite (60\% clinopyroxene (Cpx) and $40 \%$ garnet (Gt) for a deep solidus, or $75 \% \mathrm{Cpx}$ and $25 \%$ Gt with a shallower melting regime; (PERTERMANN et al., 2004)) or silica-poor garnet pyroxenite (70\% Cpx and $30 \% \mathrm{Gt}$ for deep melting, or $80 \% \mathrm{Cpx}$ and $20 \% \mathrm{Gt}$ for shallower melting), a lithology some have suggested to be a plausibly melting mantle lithology (HIRSCHMANN et al., 2003; KogISO et al., 2004). Here we calculate melts of those lithologies in a continuously melting column. We then calculate binary mixtures between the mafic lithology melts and melts of peridotites.

Sources begin in secular equilibrium. Eclogite and pyroxenite have deeper solidi than peridotite $(50 \mathrm{~km}$ and $6.5 \mathrm{~km}$ deeper than the peridotite solidus, respectively; (ELKINS et al., 2008; HirschmANn and STOLPER, 1996; KoGISO et al., 2004; PERTERmann and Hirschmann, 2003)), and productivities during melting vary considerably for all lithologies in question (ELKINS et al., 2008; HIRSCHMANN et al., 1999; Kogiso et al., 2003; PERTERmAnn and Hirschmann, 2003). As described in detail in Elkins et al. (2008), the different depths to the solidus and productivity variations for eclogite and silica-poor garnet pyroxenite are such that mafic melts are the result of much higher degrees of melting than peridotite melts extracted from the same depths, and this dominates the binary mixing paths predicted for all two-lithology melting scenarios. There are only constraints for batch melt productivities for these lithologies (KoGISO et al., 2003; PERTERMANN and HiRSCHMANN, 2003), although for the fractional melt extraction expected the degree of melting would be lower. Appendix Figure 2 shows that using batch melting productivities from the literature leads to $100 \%$ melting of both lithologies in the deep melting scenario (for shallow melting, the silica-poor pyroxenite only reaches between 60 and $70 \%$ melting using these estimates), which may not occur in a fractional melting regime; however, even with lower productivities the melt composition is dominated by initial melts, so the calculated results would be very similar to those shown in Appendix Figure 4 and discussed in Section 3.4.2.2. In Appendix Figure 4, we show mixtures of mafic melts with coexisting initial melts calculated for peridotite, i.e. mixing at the peridotite solidus, which is sufficient to demonstrate the 
mixing behavior predicted (see Elkins et al. (2008) for more details about mixing melts from two lithologies). We calculate mixtures of the first peridotite melt increment with either a $65 \%$ melt of an eclogite or a $5 \%$ melt for a garnet pyroxenite source. Initial mafic source U/Th ratios could be chosen at any value without changing the problems described in Section 3.4.2.2. Appendix Figure 4 shows results for a source that is only moderately enriched relative to the peridotite source, with $\left({ }^{238} \mathrm{U} /{ }^{232} \mathrm{Th}\right)=\left({ }^{230} \mathrm{Th} /{ }^{232} \mathrm{Th}\right)=1.00$. As a result of their deeper solidi, eclogite and pyroxenite melts produced deeper than the peridotite solidus (e.g. in veins of mafic material) cannot migrate through and equilibrate with the surrounding peridotite matrix without freezing. We thus restrict melt scenarios for mafic lithologies: only fractional and dynamic melts of these lithologies are considered, as they must be extracted without interaction with solid residue during ascent. All melts of the mafic lithologies are modal melts with constant partition coefficients and melt productivities, in part because constraints on eclogite and pyroxenite melt productivities are poor (batch melting estimates from previous studies cover wide ranges and are likely too high for fractional melts (KoGISO et al., 2003; PERTERMANN and HiRSCHMANN, 2003), and in part because only early, small F melts strongly impact the final aggregated melt composition for both fractional and dynamic models. For a summary of partition coefficients and mineral modes used, see Table 4.

Appendix Figure 4 shows the results of mixing between disequilibrium melts of the mafic mantle lithologies and equilibrium peridotite melts for (a, c) a deep melting column (peridotite solidus at a depth of $100 \mathrm{~km}$ ) and (b, d) a shallower column (peridotite solidus at $55 \mathrm{~km}$ ) for $(\mathrm{a}, \mathrm{b})$ time-independent (batch peridotite and fractional eclogite and garnet pyroxenite melts) and (c,d) time-dependent (chromatographic peridotite and dynamic mafic melts) melting models. As described above, U/Th ratios were chosen so the mafic lithology is only moderately more enriched than the peridotite. This is likely inconsequential - even with identical starting compositions mixing between melts of a mafic lithology and melts of a peridotite cannot explain most of the Kolbeinsey Ridge array. The depths to the solidi for both mafic lithologies tested are larger than for a peridotite. Also, these alternate lithologies have narrower melting intervals and are insulated super adiabatically by sub-solidus peridotite (HIRSCHMANN and STOLPER, 1996), such that even with the lower productivities that might be expected for fractional 
melting, the eclogite and pyroxenite melt must experience relatively large degrees of melting by the time the peridotite solidus is reached. With any of the melt scenarios used here, the eclogite and pyroxenite melts fail to preserve high ${ }^{230} \mathrm{Th}$ excesses by the time such large $\mathrm{F}$ values are reached (the degrees of melting at the onset of peridotite melting are possibly as high as $5 \%$ for garnet pyroxenite and $65 \%$ for eclogite, though such estimates are based on variable-productivity batch melting estimates from Pertermann et al. (2003).

When mafic melts mix with deep, small-degree peridotite melts generated at the same depth, there is no means to generate ${ }^{238} \mathrm{U}$ excess melts because all lithologies contain garnet. On the other hand, when mafic melts mix with shallow spinel peridotite melts, there is no means to generate the large ${ }^{230} \mathrm{Th}$ excesses observed in our sample suite because only the eclogite and pyroxenite are generating ${ }^{230} \mathrm{Th}$ excess in the melt, but they cannot preserve that excess. This is true for both time-independent and time-dependent models. Melts from mafic mantle lithologies, if present, cannot play a dominant role in generating the variability observed for Kolbeinsey Ridge. The deeper solidii and higher productivities of mafic lithologies than for peridotitic rocks make it impossible for e.g. eclogitic melts to have maintained large ${ }^{230} \mathrm{Th}$ excesses by the time the peridotite source begins melting. This prevents binary melt mixtures of a lithologically heterogeneous source from producing the Kolbeinsey Ridge array. This is the case regardless of initial $\mathrm{U} / \mathrm{Th}$ ratios used for the mafic source. 

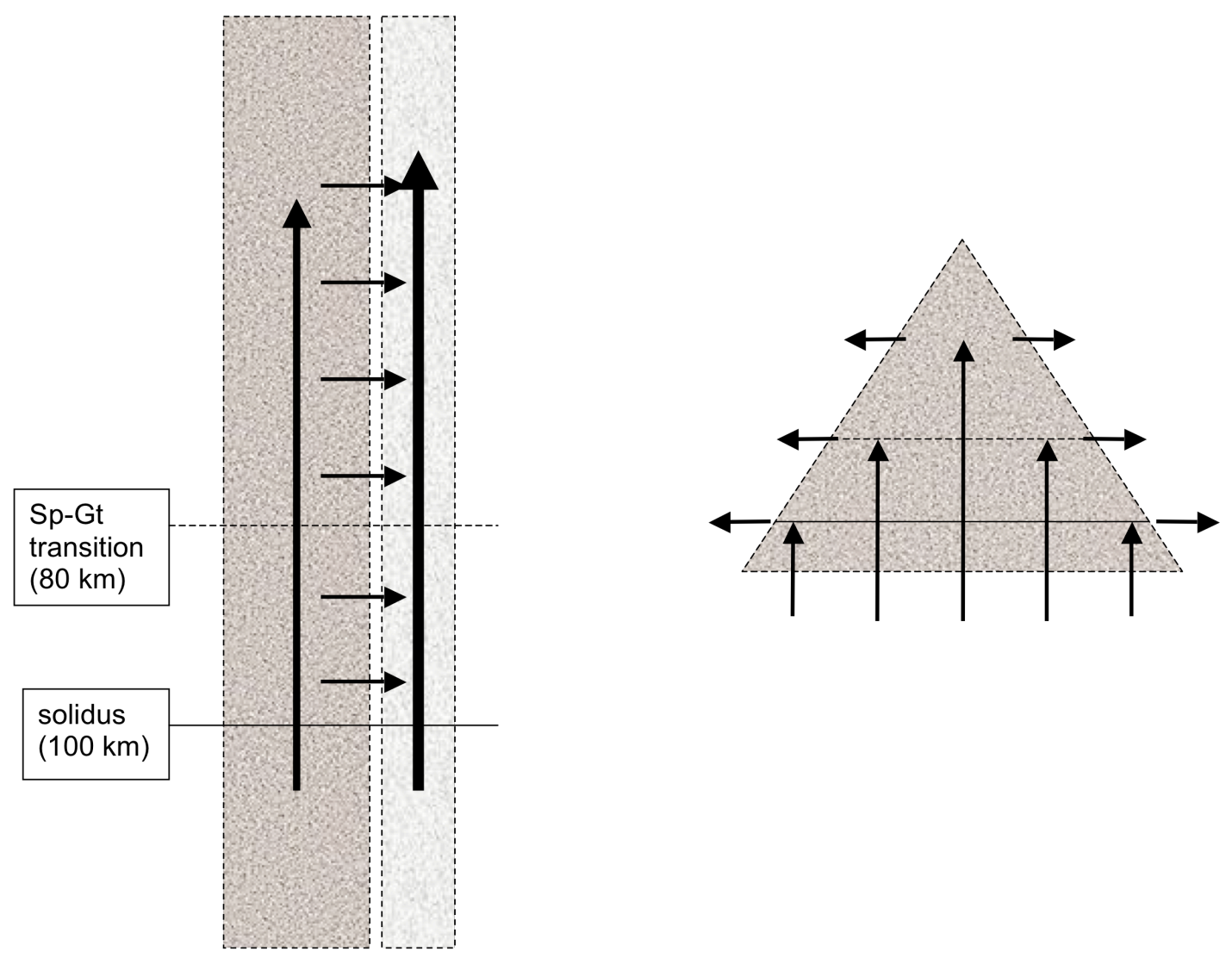

Appendix Figure 1. Schematic conceptual diagrams for two-porosity and two-dimensional melt transport regimes. On the left is a two-column melt regime, where equilibrium melts are produced in a low-porosity upwelling regime and then extracted into an adjacent, higher-porosity column, where they experience disequilibrium transport. On the right is a two-dimensional, triangular melting regime for a mid-ocean ridge setting, after Langmuir et al. (1992). 

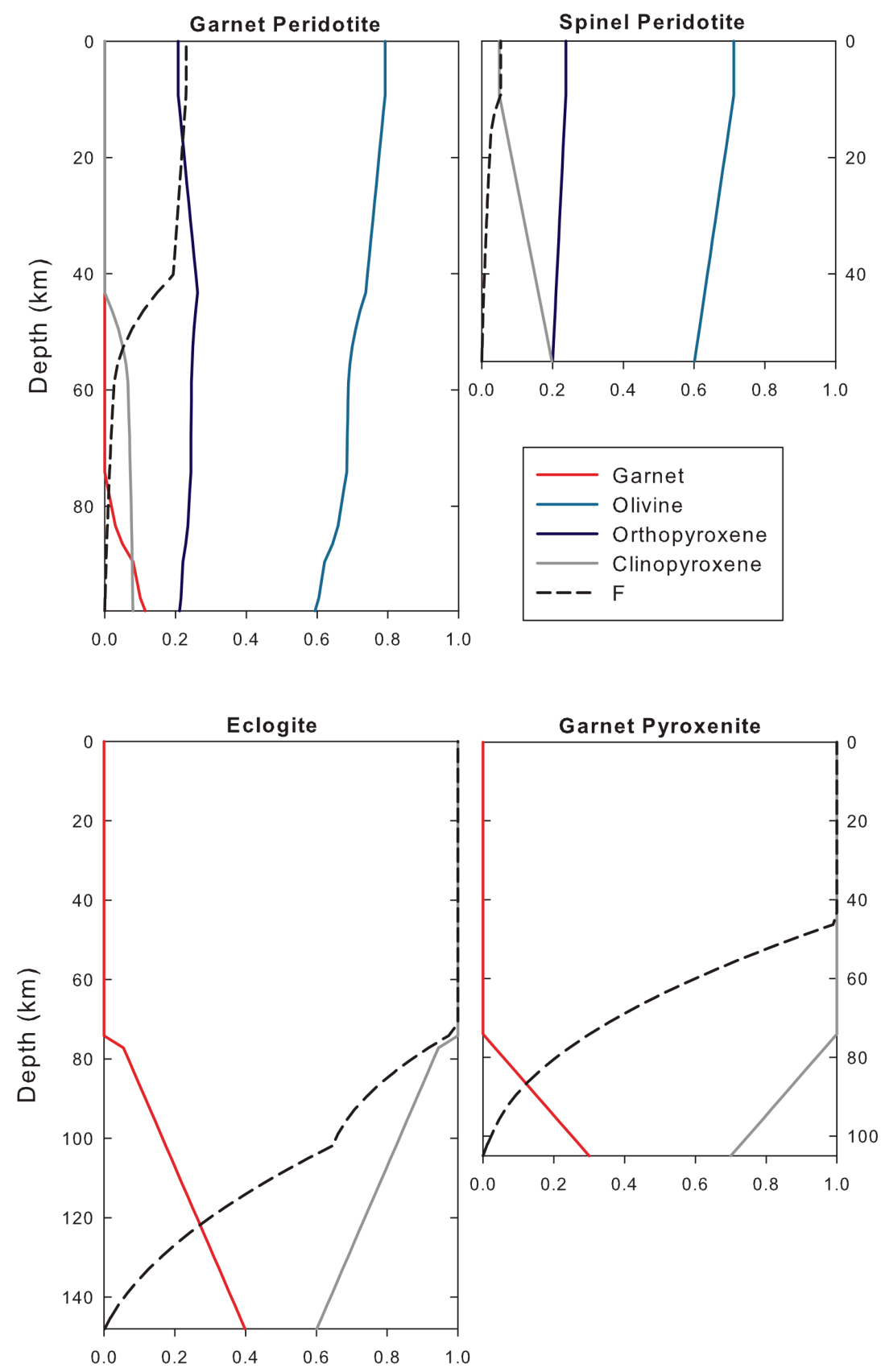

Appendix Figure 2. Model input parameters for garnet peridotite, spinel peridotite, deep eclogite, and deep garnet pyroxenite melting, as described in the Appendix. Black dashed lines represent the degree of melting $(F)$ and colored lines show the changes in mineral mode with depth in the melting columns. 


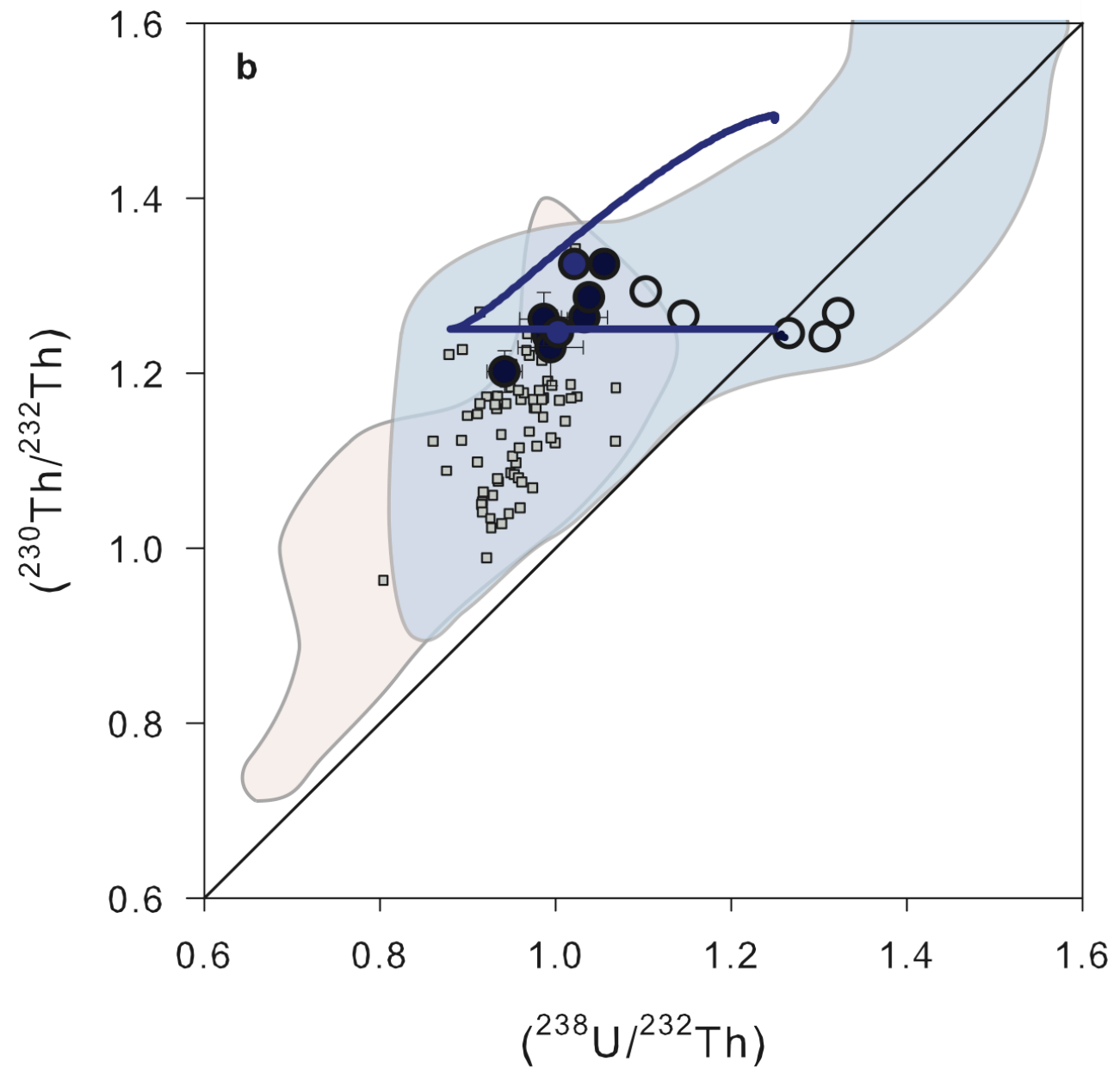

Appendix Figure 3. Equiline diagram for the Kolbeinsey Ridge basalts with a modeled garnet peridotite, continuously melting, dynamic melt trajectory (blue line), as described in the Appendix; data symbols and fields as in Figure 6. 
Two lithologies, deep melting
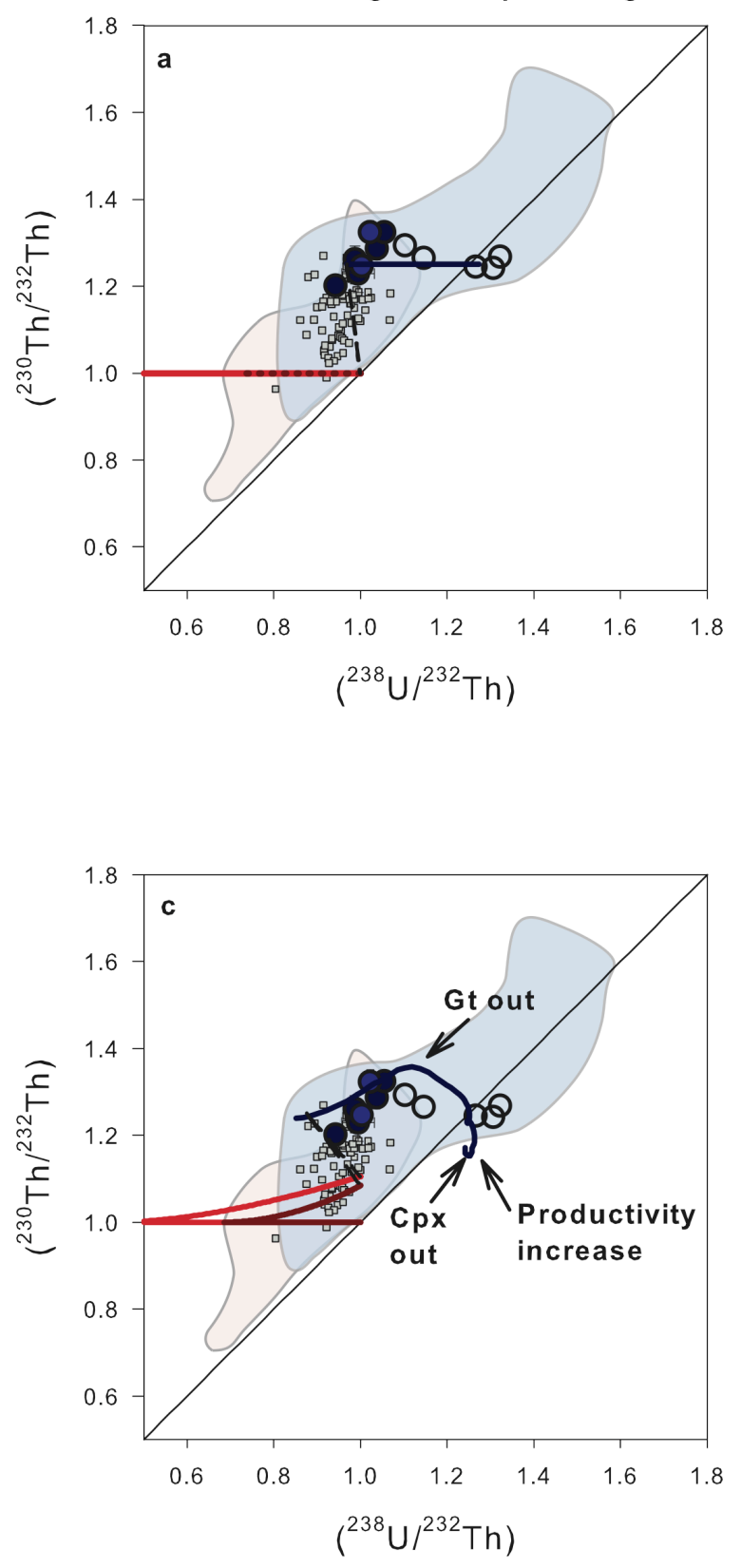

Two lithologies, shallow melting
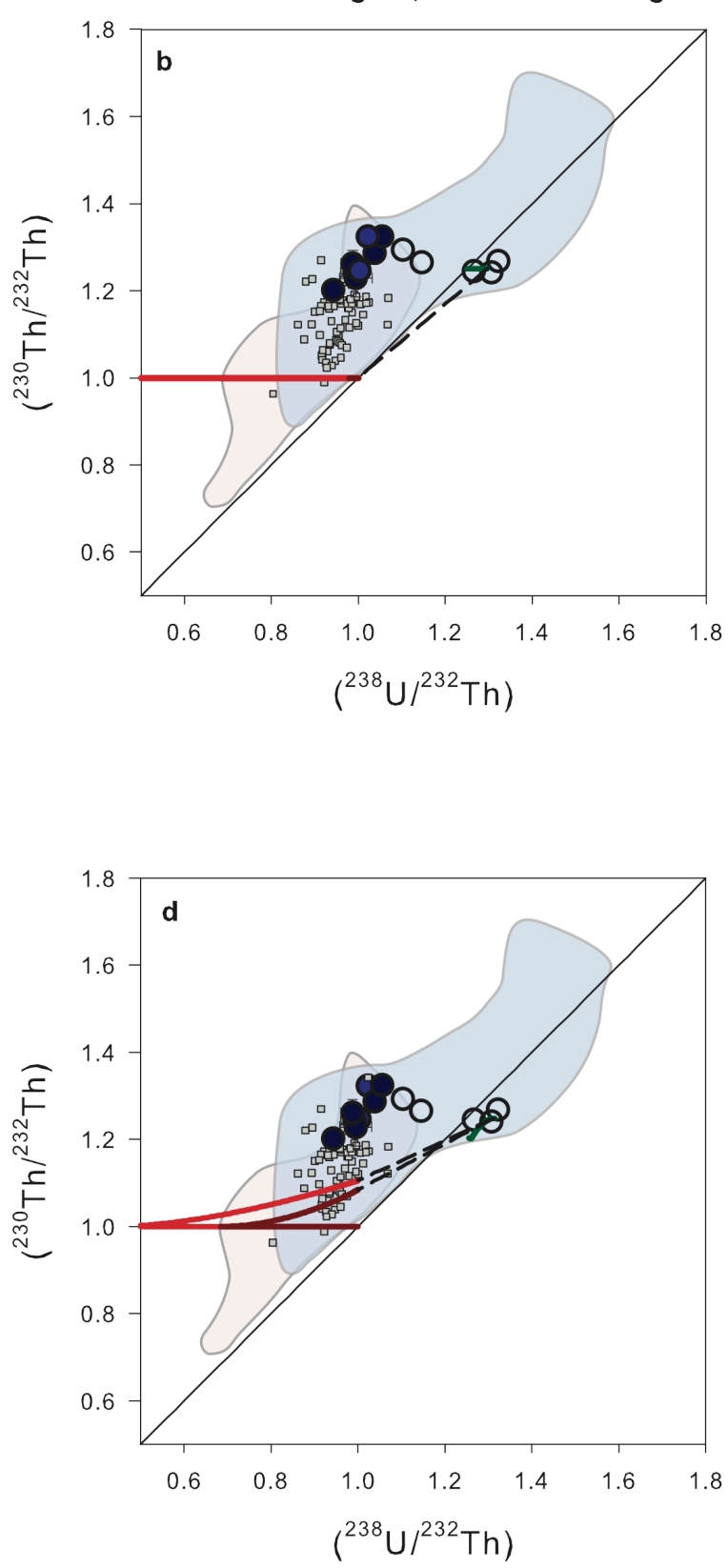

Appendix Figure 4. Equiline diagrams for the Kolbeinsey Ridge basalts, showing modeled melt trajectories for two mantle lithologies and binary melt mixing curves, as described in the Appendix. Garnet peridotite melting trajectories are shown in dark blue, spinel peridotite trajectories are green, eclogite melts are bright red lines, the trajectories for garnet pyroxenite are dark red lines, and binary mixtures are shown as dashed black lines; data symbols and fields as in Figure 6. (a) Deep melting column with time-independent melting; (b) shallow melting column with time-independent melting; (c) Deep melting column with time-dependent melting; (d) Shallow melting column with time-independent melting. 


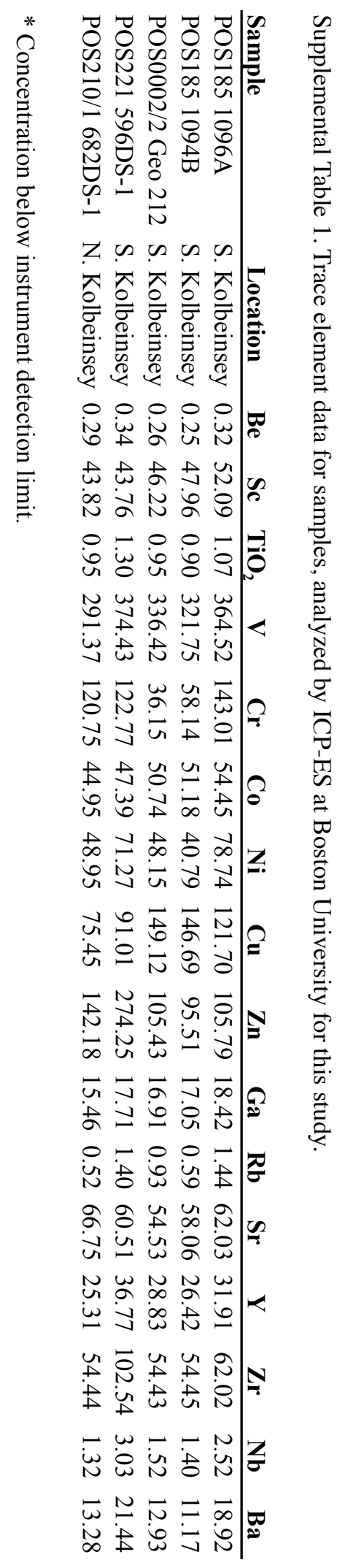




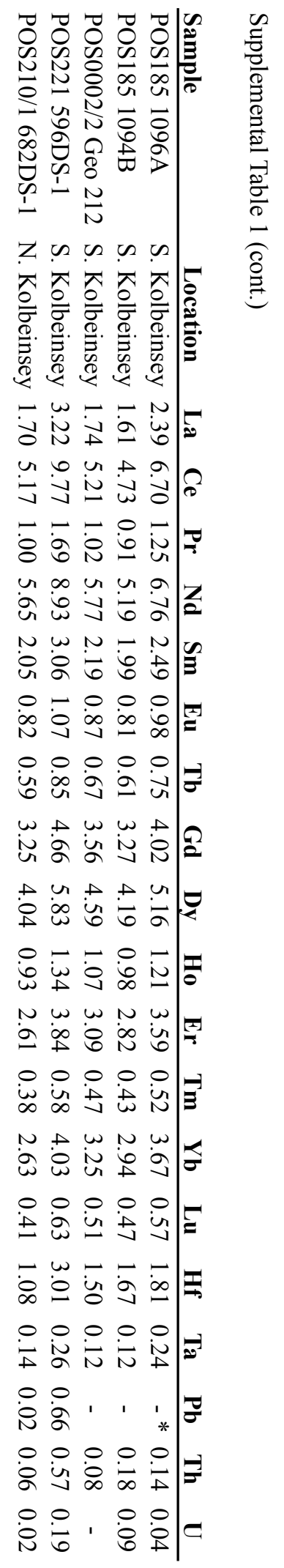


Supplemental Table 2. Calculated aSm-Nd values for samples in this study.

\begin{tabular}{llc} 
Sample & \multicolumn{1}{c}{ Location } & $\alpha_{\text {Sm-Nd }}{ }^{*}$ \\
\hline TRI0139-001-001G & Tjörnes FZ & 1.233 \\
POS185 1105B & Tjörnes FZ & 1.155 \\
POS185 1093 & S. Kolbeinsey & 1.082 \\
POS291 485-3 & S. Kolbeinsey & 1.088 \\
TRI0139-007-001G & S. Kolbeinsey & 0.983 \\
POS326 540DS-4 & S. Kolbeinsey & 1.035 \\
POS291 495-2 & S. Kolbeinsey & 1.053 \\
POS185 1096A & S. Kolbeinsey & 0.966 \\
POS185 1094B & S. Kolbeinsey & 1.024 \\
TRI0139-006-002G & S. Kolbeinsey & 1.037 \\
POLARK7-1-37DS-2 & S. Kolbeinsey & 1.115 \\
POLARK7-1-22DS-3 & S. Kolbeinsey & 0.993 \\
TRI0139-013-003G & S. Kolbeinsey & 1.045 \\
TRI0139-014-001G & S. Kolbeinsey & 0.998 \\
TRI0139-015-001G & S. Kolbeinsey & 1.058 \\
TRI0139-016-001G & S. Kolbeinsey & 1.028 \\
POS0002/2 Geo 212 & S. Kolbeinsey & 0.999 \\
TRI0139-020-001G & S. Kolbeinsey & 0.911 \\
POS221 596DS-1 & S. Kolbeinsey & 0.895 \\
POS221 605DS-2 & S. Kolbeinsey & 1.011 \\
POS210/1 682DS-1 & N. Kolbeinsey & 0.947 \\
POLARK7-1-21844 & N. Kolbeinsey & 1.081 \\
POLARK7-1-21847 & N. Kolbeinsey & 1.216 \\
POLARK7-1-21848 & N. Kolbeinsey & 1.103 \\
POLARK7-1-21850 & N. Kolbeinsey & 1.236 \\
POLARK7-1-21854 & N. Kolbeinsey & 1.185 \\
POS210/1 700 DS-2 & N. Kolbeinsey & 0.799 \\
POS210/1 702 DS-1 & N. Kolbeinsey & 0.924 \\
POS210/1 698 DS-1 & N. Kolbeinsey & 0.739 \\
TRI0139-027-005G & N. Kolbeinsey & 0.667 \\
& &
\end{tabular}

* $\alpha_{\mathrm{Sm}-\mathrm{Nd}}=(\mathrm{Sm} / \mathrm{Nd})_{\text {sample }} /(\mathrm{Sm} / \mathrm{Nd})_{\text {source, }}$, where $(\mathrm{Sm} / \mathrm{Nd})_{\text {source }}$ is derived from the measured $\varepsilon_{\mathrm{Nd}}$ value of the sample and a model age of $1.8 \mathrm{Ga}$. 


\title{
CHAPTER 4:
}

\section{GENERATION OF ${ }^{226} \mathrm{Ra}^{238} \mathrm{U}$, AND ${ }^{230}$ Th EXCESSES IN ARCTIC MID-OCEAN RIDGE BASALTS FROM THE KOLBEINSEY, MOHNS, KNIPOVICH, AND GAKKEL RIDGES}

\begin{abstract}
We present U-Th-Ra isotopic data for the slow- to ultraslow spreading Mohns, Knipovich, and Gakkel Ridges. On the ultraslow-spreading end member Gakkel Ridge, we find that MORB from the $85^{\circ} \mathrm{E}$ volcano on the Eastern Volcanic Zone are extremely homogeneous, with depleted radiogenic isotopic signatures (e.g. mean ${ }^{87} \mathrm{Sr} /{ }^{86} \mathrm{Sr}=$ $0.702612 \pm 1)$ and $\left({ }^{230} \mathrm{Th} /{ }^{238} \mathrm{U}\right)$ near $1.0($ mean $=1.01 \pm 4 \%)$ and ranging from small $(5 \%)$ ${ }^{230} \mathrm{Th}$ excesses to small ${ }^{238} \mathrm{U}$ excesses (also 5\%). All of these samples are age-constrained by $\left({ }^{226} \mathrm{Ra} /{ }^{230} \mathrm{Th}\right)$ ratios ranging from 3.07 to $3.65 \pm 3 \%$, and one sample is additionally constrained to younger than 100 years old by $\left({ }^{210} \mathrm{~Pb} /{ }^{226} \mathrm{Ra}\right)=0.89 \pm 9 \%$. The $\left({ }^{226} \mathrm{Ra} /{ }^{230} \mathrm{Th}\right)$ and $\left({ }^{230} \mathrm{Th} /{ }^{238} \mathrm{U}\right)$ lie along a global negative correlation, supporting their production by mixing of melts from different depths.

In Chapter 3, we found that mid-ocean ridge basalts (MORB) from Kolbeinsey Ridge have uniformly high ${ }^{230} \mathrm{Th}$ excess for a narrow range of $\left({ }^{230} \mathrm{Th} /{ }^{232} \mathrm{Th}\right)$ and formed in a long, deep mantle melting column. A relatively uniform degree of ${ }^{230} \mathrm{Th}^{238} \mathrm{U}$ disequilibrium is observed for isotopically enriched Kolbeinsey Ridge samples north of $70.6^{\circ} \mathrm{N}$, the Mohns Ridge, and the Knipovich Ridge $\left(\right.$ mean $\left.\left({ }^{230} \mathrm{Th} /{ }^{238} \mathrm{U}\right)=1.17 \pm 6 \%\right)$. Age-constrained $\left(\left({ }^{226} \mathrm{Ra} /{ }^{230} \mathrm{Th}\right)\right.$ values out of equilibrium) samples from Mohns Ridge cluster with mean $\left({ }^{230} \mathrm{Th} /{ }^{238} \mathrm{U}\right)=1.22$ (ranging from $1.165 \pm 0.007$ to $1.30 \pm 0.03$ ), while Knipovich Ridge samples form a sloped array parallel to the "equiline" on a $\left({ }^{238} \mathrm{U} /{ }^{232} \mathrm{Th}\right)$ vs. $\left({ }^{230} \mathrm{Th} /{ }^{232} \mathrm{Th}\right)$ diagram (slope $\left.=1.0 ; \mathrm{r}^{2}=0.8\right)$. Three samples from the Kolbeinsey Ridge north of $70.6^{\circ} \mathrm{N}$ also form a steeply-sloped array (slope $=1.9 ; \mathrm{r}^{2}=0.99$ ). If the
\end{abstract}


mantle below the Knipovich Ridge and Mohns Ridge is similar, as suggested by radiogenic isotopes, these data sets may together form a single sloped array. Position on this array correlates with radiogenic isotope compositions (e.g. ${ }^{87} \mathrm{Sr} /{ }^{86} \mathrm{Sr}$ and $\left.{ }^{147} \mathrm{Nd} /{ }^{144} \mathrm{Nd}\right)$, suggesting that mantle source heterogeneity controls the $\left({ }^{238} \mathrm{U} /{ }^{232} \mathrm{Th}\right)$ and $\left({ }^{230} \mathrm{Th} /{ }^{232} \mathrm{Th}\right)$ for this region. This is in direct contrast to the homogeneous source compositions and melt process control on ${ }^{238} \mathrm{U}_{-}^{230} \mathrm{Th}$ disequilibria for $85^{\circ} \mathrm{E}$ Gakkel Ridge and Kolbeinsey Ridge data.

Globally, mean $\left({ }^{230} \mathrm{Th} /{ }^{238} \mathrm{U}\right)$ vs. axial ridge depth for discrete MOR segments forms a negative correlation, supporting a global mantle temperature and peridotitic melting control on generation of U-Th disequilibrium in MORB. However, the variance of $\left({ }^{230} \mathrm{Th} /{ }^{238} \mathrm{U}\right)$ ratios in MORB and slopes of arrays formed by individual ridge segments result from a variety of factors including melting of heterogeneous mantle sources. This is in keeping with the relatively large variations in $\left({ }^{230} \mathrm{Th} /{ }^{238} \mathrm{U}\right)$ coupled with correspondingly small ${ }^{87} \mathrm{Sr} /{ }^{86} \mathrm{Sr}$ variations observed in MORB, also suggested by Sims and Hart (2006) to reflect the large variations in melt process occurring at MOR settings. 


\subsection{INTRODUCTION}

\subsubsection{Uranium-Series Isotopes at Slow-Spreading Mid-Ocean Ridges}

Uranium-series isotopes are an ideal tool for studying processes occurring over timescales similar to their half-lives, such as melting and melt transport in the mantle. The study of U-series isotopes, in combination with major element, trace element, and long-lived radiogenic isotopic data, can thus help constrain how source composition variations, timing of melting, melt transport, and upwelling rates impact mid-ocean ridge (MOR) basalt chemical and isotopic data. There have been systematic studies of MOR basalt (MORB) that include complete U-series, isotopic, and major and trace element data sets, but none in the Arctic MOR north of Iceland prior to the work presented in

Chapter 3. The slow- to ultraslow-spreading Arctic MOR provide a regional case study of melting in a slowly upwelling region.

Here we build on the work presented in Chapter 3 with data from a suite of samples for the full Arctic Ridge system northward of the Kolbeinsey Ridge. Previous Useries studies have suggested that melting to produce MORB must be complex, incorporating the effects of time-dependent melting, melt transport variations, and potential source compositional heterogeneities (BOURDON et al., 1996b; JULL et al., 2002; KELEMEN et al., 1997; LundSTROM, 2000; LundSTROM, 2003; LundSTROM et al., 1998a; Sims et al., 2002; Sims et al., 1999b; SPIEGElman and ElliotT, 1993; TEPLEY et al., 2004). In this chapter we evaluate such scenarios from the perspective of a set of extremely slow-spreading ridges, to better constrain the characteristics of melting beneath the global mid-ocean ridge system.

\subsubsection{Global Observations and the Arctic MOR}

In ocean island basalt (OIB) settings, which are characterized by active mantle upwelling, melting in regions of relatively slow upwelling produces enhanced ingrowth 
of ${ }^{230} \mathrm{Th}$ relative to its parent ${ }^{238} \mathrm{U}$, so that lavas from slowly upwelling regions are expected to have larger ${ }^{230} \mathrm{Th}^{2}{ }^{238} \mathrm{U}$ disequilibria than melts produced at fast upwelling regions, such as at plume centers (KOKFELT et al., 2003; SIMS et al., 1999a). In MORB settings the extent of disequilibria measured did not directly correlate with spreading rate, so Lundstrom et al. (1998b) suggested that the sloped arrays of MORB observed on plots of $\left({ }^{238} \mathrm{U} /{ }^{232} \mathrm{Th}\right)$ vs. $\left({ }^{230} \mathrm{Th} /{ }^{232} \mathrm{Th}\right)$ ("equiline" diagrams) for discrete ridge segments could result from binary mixing of melts of enriched mafic and depleted peridotitic lithologies at different upwelling rates. However, Sims et al. (2002) observed that the sloped array produced by data from $9-10^{\circ} \mathrm{N}$ EPR mid-ocean-ridge basalts (MORB) did not fit this model, because although the steep slope observed would be expected for a fast-spreading ridge such as the EPR, the radiogenic isotopes indicated a homogeneous mantle source. Sims et al. (2002) instead suggested that deep melts of a garnet peridotite, extracted in a high-porosity channel, could mix with shallower melts to produce the observed U-Th systematics. They suggested that the negative correlation between $\left({ }^{230} \mathrm{Th} /{ }^{238} \mathrm{U}\right)$ and $\left({ }^{226} \mathrm{Ra} /{ }^{230} \mathrm{Th}\right)$ disequilibria for the $9-10^{\circ} \mathrm{N}$ lavas, whose ages are young compared to the half-life of ${ }^{226} \mathrm{Ra}$ supported this scenario, since only shallow melts can preserve large ${ }^{226} \mathrm{Ra}$ excess (we note that this correlation was also observed for the Juan de Fuca and Gorda Ridges, but the ages of those samples were uncertain relative to the half-life of ${ }^{226} \mathrm{Ra}$ (Kelemen et al., 1997; Sims et al., 1995; Volpe and Goldstein, 1993)). Deep melts with strong garnet signatures (large ${ }^{230} \mathrm{Th}$ excesses) cannot preserve ${ }^{226} \mathrm{Ra}$ excess during melt transport to the surface, while melts with smaller ${ }^{230} \mathrm{Th}$ excesses or even ${ }^{238} \mathrm{U}$ excesses come from shallower depths in the melt column and can better preserve ${ }^{226} \mathrm{Ra}$ excesses during their shorter melt transport times.

Klein and Langmuir (1987) observed that the depth to mid-ocean ridge axes correlates with both the degree and the mantle depth of MORB melting, as indicated by major elements in the lavas (i.e. $\mathrm{Na}_{8}$ and $(\mathrm{Ca} / \mathrm{Al})_{8}$ for degree of melting, and $\mathrm{Fe}_{8}$ for depth of melting). They suggested that this indicates that a thicker crust is produced by a longer melt column and higher degree of melting. Bourdon et al. (1996b) later observed that the measured $\left({ }^{230} \mathrm{Th} /{ }^{238} \mathrm{U}\right)$ for MORB inversely correlates with depth to the ridge axis. They 
suggested that a thicker crust (i.e. higher degree of melting) and correspondingly deeper melt column produce larger ${ }^{230} \mathrm{Th}$-excess by generating more melt in the garnet stability field. Our new measurements from the slow- to ultraslow-spreading ridges north of Iceland range from the thick crustal endmember of Klein and Langmuir (1987), the Kolbeinsey Ridge (averaging $1100 \mathrm{~m}$ deep) to the deep Gakkel Ridge (up to $5000 \mathrm{~m}$ deep; see Figure 1b), making this region ideal for examining the relationship between ${ }^{238} \mathrm{U}^{230} \mathrm{Th}$ disequilibria and axial depth.

The mantle beneath the Mohns Ridge and the Knipovich Ridge is hypothesized to contain trapped subcontinental lithospheric material, based on long-lived radiogenic isotope systematics of MORB from those ridges (Blichert-Toft et al., 2005). This region provides a contrast to our findings in Chapter 3 for the Kolbeinsey Ridge, where the measured samples show very little isotopic variability (BLICHERT-TOFT et al., 2005; Devey et al., 1994; Mertz et al., 1991; MerTZ and HaASe, 1997; Schilling et al., 1999). The Mohns and Knipovich Ridges thus provide an opportunity to evaluate the influence of source heterogeneity on U-series isotope variations at similarly slow spreading rates to the Kolbeinsey Ridge.

Uranium-series analysis of Arctic lavas thus provides an endmember test for 1) the robustness of the two-porosity melting model for the full range of oceanic spreading rates, 2) the role of mantle heterogeneity, and 3) the relationship between crustal thickness and melt process. In this study we present the results of ${ }^{238} \mathrm{U},{ }^{230} \mathrm{Th},{ }^{226} \mathrm{Ra}$, and ${ }^{210} \mathrm{~Pb}$ isotopic analysis for a suite of 27 samples from the Arctic MOR system, and then we compare these results with data from the Kolbeinsey Ridge (see Chapter 3) as well as the global ridge system. We find that melt composition is generally controlled by mantle temperature as well as variations in the process of melting and melt extraction in a peridotitic melting column, but that the presence of significant compositional mantle heterogeneities can also influence melt composition. 


\subsection{GEOLOGIC SETTING}

Overall, the oceanic basins north of Iceland are relatively young in age. Rifting between Greenland and Eurasia began at 53-55 Ma, forming the Aegir, Jan Mayen, Mohns, and Gakkel Ridges (Blichert-Toft et al., 2005; Glebovsky et al., 2006; Schilling et al., 1999; Shipilov, 2008). At $45 \mathrm{Ma}$, a north-propagating rift axis initiated to the west of the Jan Mayen Ridge, simultaneous with continued Aegir Ridge spreading. The northern propagation of this early Kolbeinsey Ridge led to the breaking off of a fragment of the Jan Mayen Ridge around $43 \mathrm{Ma}$, and by 26 Ma spreading ceased on the Aegir Ridge and continued solely on the Kolbeinsey Ridge, trapping a fragment of continental lithospheric material south of Jan Mayen Island. At 25 Ma the spreading direction of the Mohns Ridge changed from NNW-SSE to NW-SE (Mjelde et al., 2008a). It has been suggested that the transform between the Mohns and Gakkel Ridges then began to experience spreading, developing into what is now the highly oblique Knipovich Ridge (e.g. (Okino et al., 2002)). (See Figure 1 for a regional map and sample locations for this study.)

Crustal thickness varies widely along the Arctic ridge system. Thicknesses along the Kolbeinsey Ridge axis reach 15 km (Kodaira et al., 1997; Mjelde et al., 2008b), most likely due to its proximity to Iceland and consequently hotter mantle temperatures.

Spreading is nearly orthogonal to the ridge axis (spreading rate is $\sim 18 \mathrm{~mm} / \mathrm{yr}$.; (Breivik et al., 2006; Mosar et al., 2002)) and the ridge is volcanically active along its entire length. The Mohns (17 mm/yr. spreading rate (Mosar et al., 2002)) and Knipovich Ridges (up to $16 \mathrm{~mm} / \mathrm{yr}$.; (Mosar et al., 2002)) have estimated crustal thicknesses of 4 to $8 \mathrm{~km}$, based on seismic data (Kandilarov et al., 2008; Klingelhofer et al., 2000; Ljones et al., 2004; Okino et al., 2002). The Mohns Ridge spreads NW-SE, which is oblique to the orientation of the axis, and Knipovich Ridge spreading is even more highly oblique (35 $49^{\circ}$ obliquity; (Okino et al., 2002)). The ultraslow Knipovich Ridge contains amagmatic as well as magmatic sections, and the ridge axis is located in a series of pull-apart basins along the strike of the ridge that are underlain by small-scale transform structures 


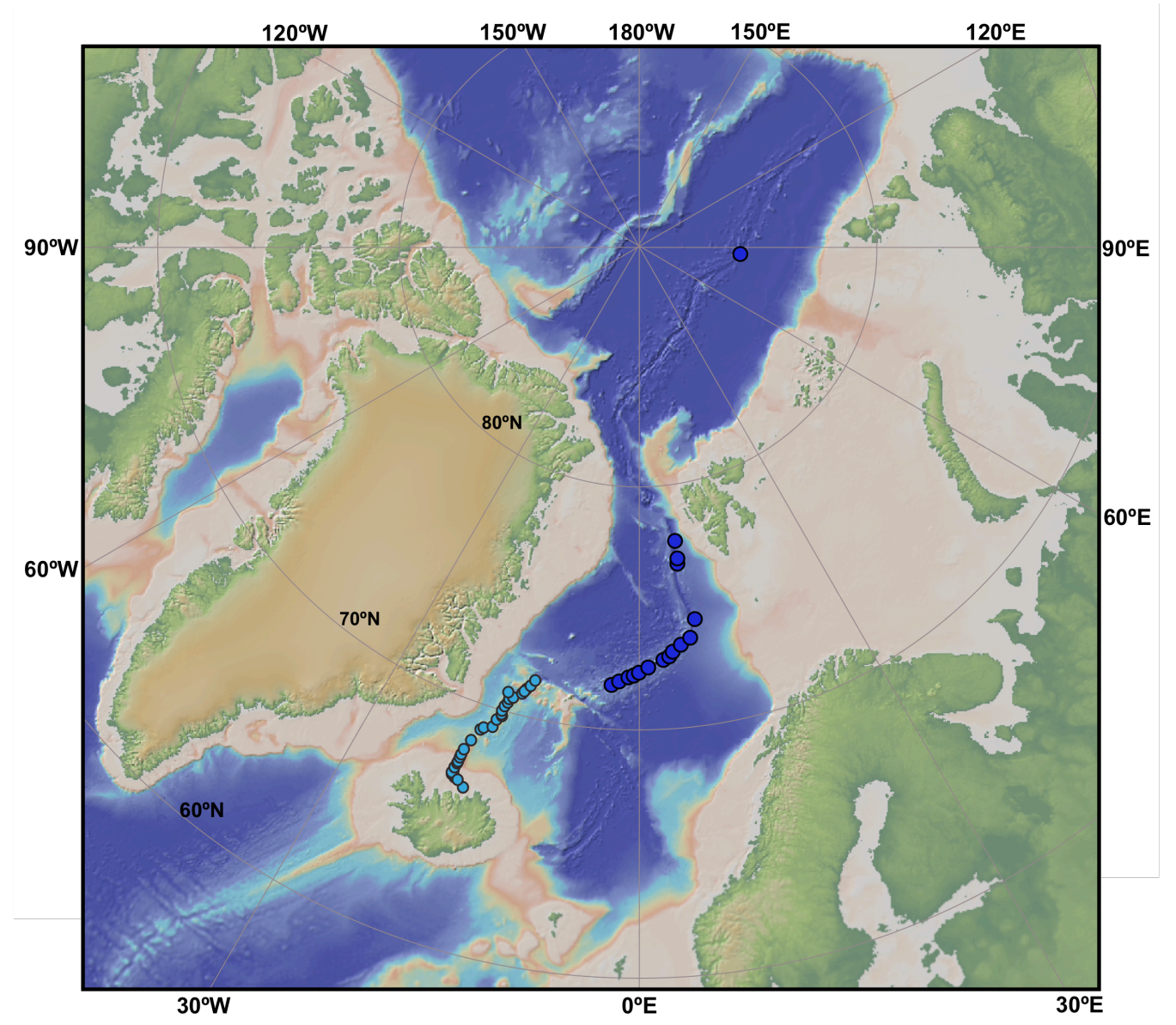

a

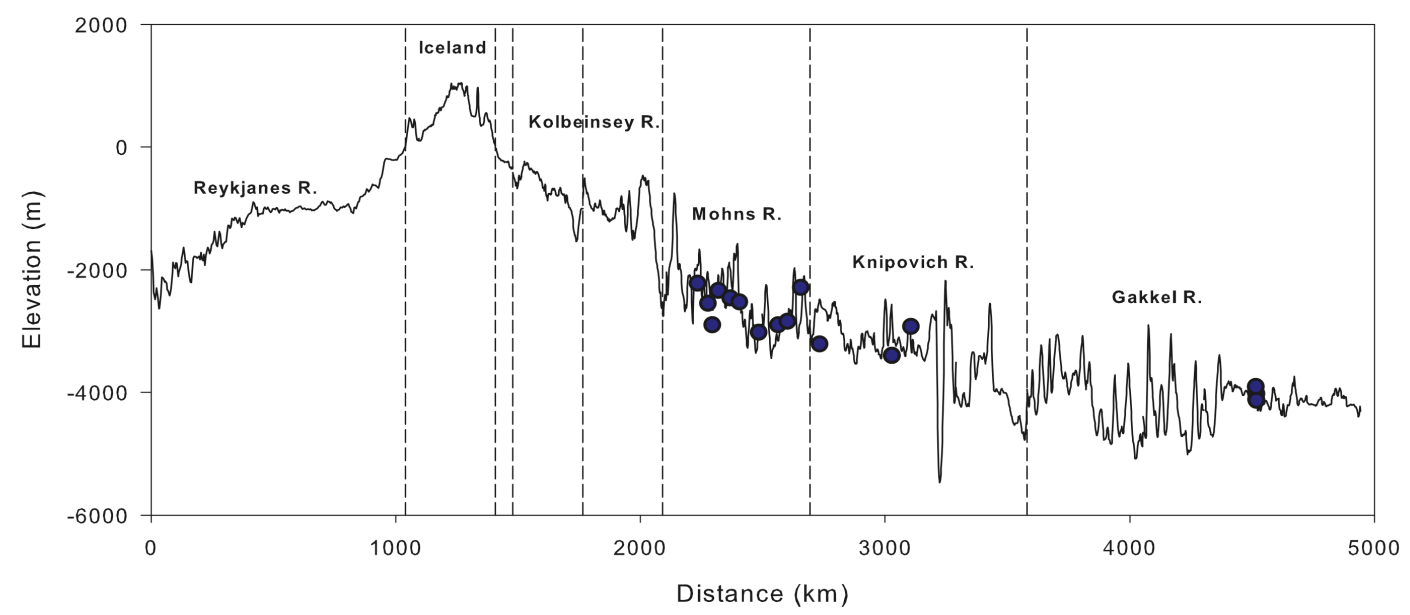

b

Figure 1. a) Regional map showing dredge and dive locations of samples analyzed in this study, with recent bathymetric data by Smith and Sandwell (1997) and Jakobsson et al. (2008). b) Bathymetric and topographic profile along the Arctic ridge system, showing sample locations for this study. 
(Okino et al., 2002). Gakkel Ridge crust, due to the cold, thick lithosphere underlying ultraslow spreading centers, is extremely thin $(\leq 3 \mathrm{~km})$ and amagmatic in many locations, with local thickening beneath isolated active volcanoes along the ridge axis (Jokat and Schmidt-Aursch, 2007). Gakkel is divided into three regions with distinct morphology and volcanic character: the Western Volcanic Zone (WVZ), which has active magmatic centers along its length and spreads at $\sim 13 \mathrm{~mm} / \mathrm{yr}$;; the Sparsely Magmatic Zone, where spreading is mainly amagmatic; and the EVZ, where volcanism occurs at discrete volcanic centers and spreading rate is less than $12 \mathrm{~mm} / \mathrm{yr}$. (Goldstein et al., 2008; Michael et al., 2003).

Previous work (Blichert-Toft et al., 2005; Devey et al., 1994; Mertz et al., 1991; Mertz and Haase, 1997; Schilling et al., 1999) has shown that MORB from the Kolbeinsey Ridge are overall radiogenic-isotope depleted as well as extremely traceelement depleted. Isotopic ratios are more enriched near Iceland and also near the Jan Mayen Platform and Fracture Zone (FZ) (Mertz et al., 2004), though trace elements remain depleted as far south as the Tjörnes FZ just offshore of the northern Icelandic margin (Figure 2). Elevated ${ }^{3} \mathrm{He} /{ }^{4} \mathrm{He}$ ratios with approach to Iceland along the Kolbeinsey Ridge suggest that the increased isotopic enrichment near Iceland is related to the Icelandic hotspot (Schilling et al., 1999). There is no such anomaly near Jan Mayen, however, and other sources for the increased isotopic enrichment have been suggested for the area near the Jan Mayen FZ. Haase et al. (1996) suggested that Jan Mayen may be the result of a locally wetter mantle, preferentially tapping mantle heterogeneities, or that there may be trapped lithospheric material present from early basin formation. Trønnes et al. (1999) suggested that Jan Mayen represented a small microplate of rifted Greenland material that is experiencing a relatively low degree of melting.

MORB north of the Jan Mayen FZ show variable amounts of isotopic and trace element enrichment, but are generally more enriched than the Kolbeinsey Ridge. Blichert-Toft et al. (2005) performed a principal-component analysis for the Kolbeinsey, Mohns, and Knipovich Ridges, and they suggested that while along the Kolbeinsey all of 

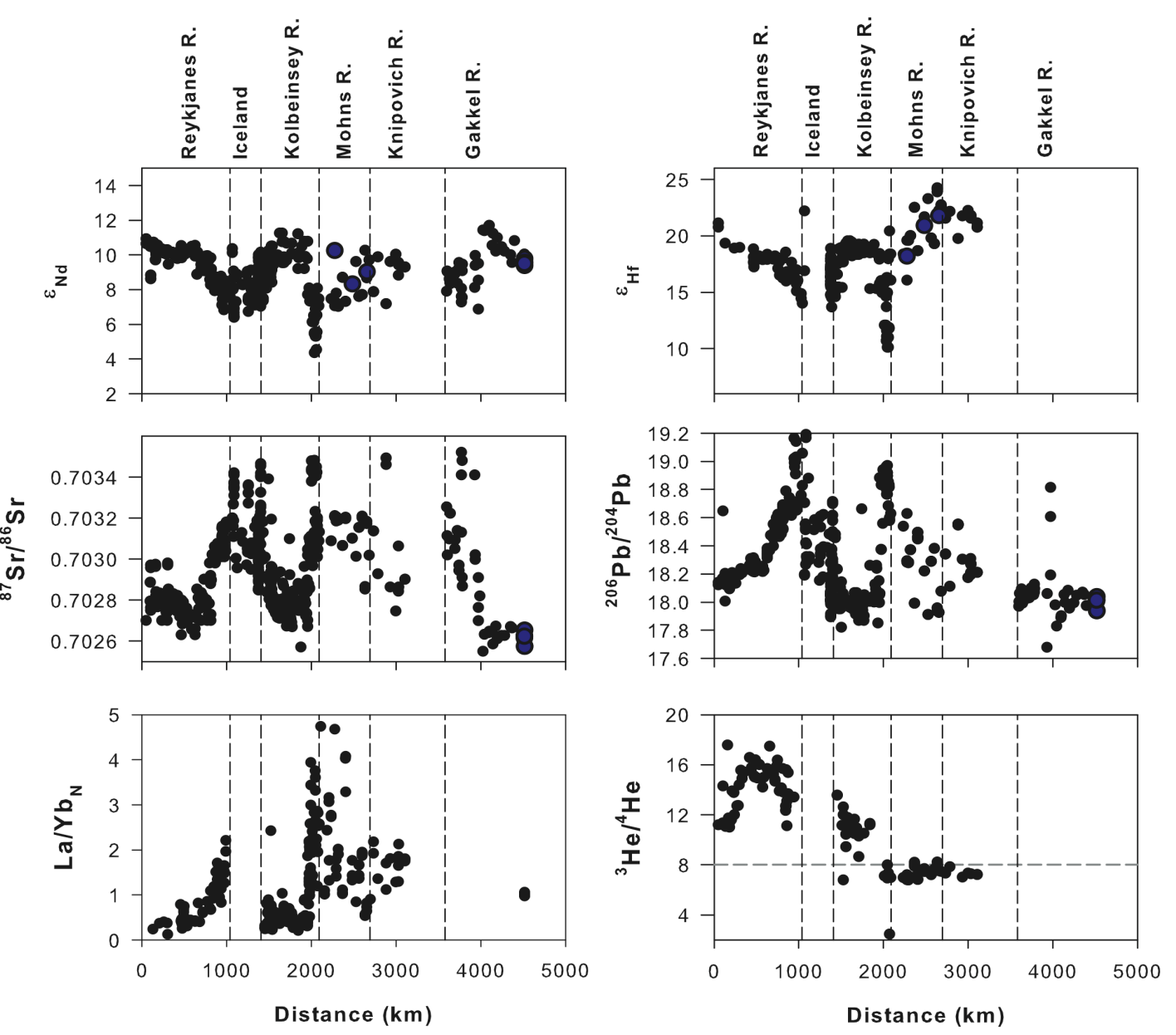

Figure 2. Distance along the Arctic ridge system vs. isotopic and trace element data in MORB (BLICHERT-TOFT et al., 2005; COHEN et al., 1980; CONDOMINES et al., 1981; DEVEY et al., 1994; DUPRE and ALLEGRE, 1980; FURMAN et al., 1991; GOLDSTEIN et al., 2008; HAASE et al., 2003; HANAN et al., 2000; HARDARSON and FITTON, 1997; HARDS et al., 1995; HEMOND et al., 1993; Hilton et al., 2000; MERTZ et al., 1991; MERTZ and HAASE, 1997; MURTON et al., 2002; NeumanN and Schilling, 1984; O'NiONS and PANKHURS.RJ, 1973; Peate et al., 2001; PoredA et al., 1986; SALTERS and WHITE, 1998; SCHILLING, 1975; SCHILling et al., 1999; SCHILLING et al., 1983; SIGURDSSON, 1981; STECHER et al., 1999; STRACKE et al., 2006; STRACKE et al., 2003a; STRACKE et al., 2003b; SUN and JAHN, 1975; THIRLWALL et al., 2004; WAGGONER, 1989). New data from this study are shown as blue data points. 
the variance can be explained by mixing between "depleted MORB mantle" (DMM) and "FOZO" (Hart et al., 1992) source components, the more northerly ridges have additional input from a more enriched source, though it was not possible to discern the exact composition of that enriched component. Anomalously depleted $\varepsilon_{\mathrm{Hf}}$ values relative to $\varepsilon_{\mathrm{Nd}}$ for these two ridges were cited by Blichert-Toft et al. (2005) to suggest the presence of streaks of subcontinental lithospheric material in the mantle beneath Mohns and Knipovich Ridges.

Goldstein et al. (2008) observed that Gakkel Ridge lavas from the WVZ are distinct from those in the EVZ. WVZ lavas have a Pb isotope "DUPAL" signature that the EVZ MORB lack, suggesting the presence of subcontinental material trapped in the WVZ mantle as well; Goldstein et al. (2008) suggested that this material was a remnant from Svalbard-Greenland rifting.

In Chapter 3, we found that Kolbeinsey MORB have high $\left({ }^{230} \mathrm{Th} /{ }^{238} \mathrm{U}\right)$ for a relatively narrow span of $\left({ }^{230} \mathrm{Th} /{ }^{232} \mathrm{Th}\right)$, as shown in Figure 3. These lavas have a relatively narrow range of ${ }^{87} \mathrm{Sr} /{ }^{86} \mathrm{Sr}, \varepsilon_{\mathrm{Nd}}, \varepsilon_{\mathrm{Hf}}, \mathrm{La} / \mathrm{Yb}$, and $\mathrm{Pb}$ isotopic values, indicating a relatively homogeneous mantle source. ${ }^{230}$ Th-excess in mantle melts requires melting in the presence of garnet $\left(\mathrm{D}_{\mathrm{U}}>\mathrm{D}_{\mathrm{Th}}\right.$; (BEAtTIE, 1993a; BEATtie, 1993b; Hauri et al., 1994; LA Tourette and BurnetT, 1992; LA Tourette et al., 1993; SALters and Longhi, 1999; SALTERS et al., 2002) or high-pressure clinopyroxene (Landwehr et al., 2001; Wood et al., 1999). In Chapter 3 we argued for a deep melt column to produce these lavas. Trace elements suggest a young, depleted mantle source.

As described in Chapter 3, lavas from the Kolbeinsey Ridge north of $70.6^{\circ} \mathrm{N}$, unlike other Kolbeinsey MORB, demonstrate enriched isotopic and trace element signatures associated with the adjacent Jan Mayen Ridge and Fracture Zone (MERTZ et al., 2004). We thus expect the far-north Kolbeinsey Ridge samples reported in Chapter 3 to be more similar to southern Mohns Ridge samples with enriched radiogenic isotopes than to the rest of the Kolbeinsey Ridge.

Samples measured for this study comprise dredged basaltic glasses from cruises R/V Trident leg 139 in 1971, R/V Endeavor leg 26 in 1973, and a R/V Professor 


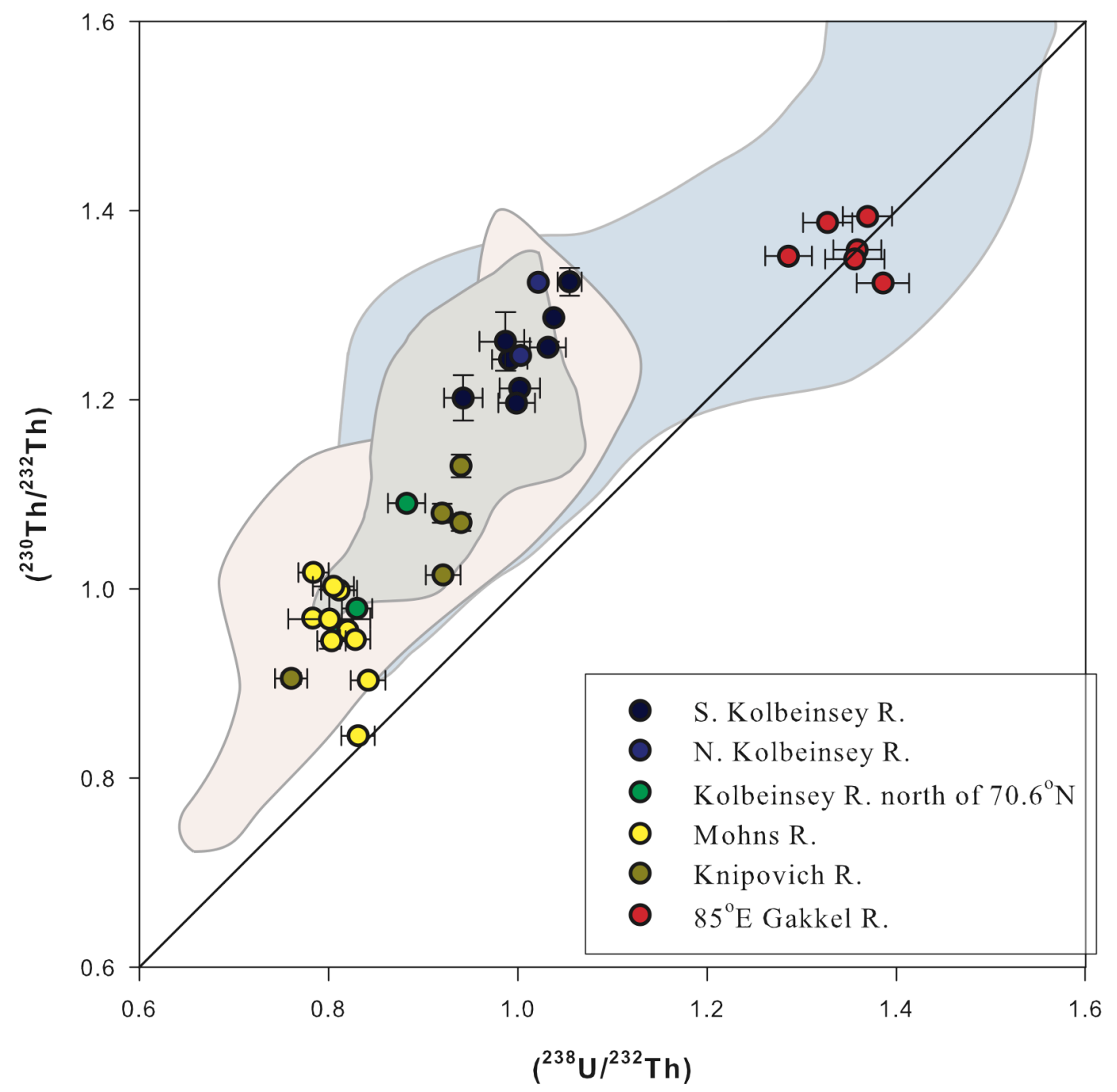

Figure 3. $\left({ }^{238} \mathrm{U} /{ }^{232} \mathrm{Th}\right)$ vs. $\left({ }^{230} \mathrm{Th} /{ }^{232} \mathrm{Th}\right)$ "equiline" diagram showing data from Chapter 3 (Kolbeinsey Ridge data points) and this study (Mohns Ridge, Knipovich Ridge, and Gakkel Ridge data), with global MORB (BOURDON et al., 1996a; GOLDSTEIN et al., 1989; GOLDSTEIN et al., 1992; GOLDSTEIN et al., 1993; LUNDSTROM et al., 1999; PEATE et al., 2001; SiMS et al., 1995; SIMS et al., 2002; STURM et al., 2000; TEPLEY et al., 2004), OIB (BOURDON et al., 1998; Claude-IVAnaJ et al., 1998; Claude-IVANaJ et al., 2001; PietruszKa et al., 2001; SIGMARSSON et al., 1998; SIMS et al., 1999a; SIMS et al., 1995; SIMS and HART, 2006; SIMS et al., 2008; TURNER et al., 1997; WIDOM et al., 1997), and Iceland (KOKFELT et al., 2003; STRACKE et al., 2003a; STRACKE et al., 2003b) fields in blue, red, and gray for comparison, respectively. Samples from north of $70.6^{\circ} \mathrm{N}$ on the Kolbeinsey Ridge, which are enriched and isotopically distinct, are separated from the rest of the Kolbeinsey data and more closely resemble Mohns Ridge and Knipovich Ridge samples. These northern Kolbeinsey samples and the Knipovich Ridge data both form sloped arrays. Age-constrained Mohns Ridge ${ }^{238} \mathrm{U}_{-}{ }^{230} \mathrm{Th}$ data (Table 2; see Section 4.4) cluster tightly at the enriched end of these arrays. Gakkel Ridge samples are highly depleted and homogeneous and range from $5 \%{ }^{230} \mathrm{Th}$ excess to $5 \%{ }^{238} \mathrm{U}$ excess. 
Logatchev cruise to the Knipovich Ridge in 1996, and samples retrieved by the Camper ROV on the R/V Oden Expedition 11/AGAVE cruise to the Gakkel Ridge (2007). The full suite of samples for which new data are reported in this study are listed in Table 1 and shown in Figure 1.

\subsection{RESULTS}

\subsection{1. ${ }^{238} \mathrm{U}_{-}^{234} \mathrm{U}$}

We analyzed $\left({ }^{234} \mathrm{U} /{ }^{238} \mathrm{U}\right)$ by Plasma Ionization Multi-collector Mass Spectrometry (PIMMS) at the Woods Hole Oceanographic Institution (WHOI), Woods Hole, MA and the University of Bristol, Bristol, UK (Table 2). $\left({ }^{234} \mathrm{U}{ }^{238} \mathrm{U}\right.$ ) is sensitive to contamination with seawater, which has $\left({ }^{234} U /{ }^{238} U\right)=1.14$, while newly erupted basalt has $\left({ }^{234} U /{ }^{238} U\right)$ in equilibrium (i.e. $\left({ }^{234} \mathrm{U} /{ }^{238} \mathrm{U}\right)=1.000$ ) (HENDERSON et al., 1993; KU et al., 1977). All analyses were performed on handpicked glass shards. We restrict further consideration of our samples to those samples with $\left({ }^{234} \mathrm{U} /{ }^{238} \mathrm{U}\right)=1.000 \pm 0.5 \%$, which indicates minimal post-eruption alteration of the rock. Four samples are excluded by this method. As in Chapter 3, one sample was not successfully measured at WHOI and three samples from Kiel, Germany (see Section 4.3.2) do not have measurements for $\left({ }^{234} U /{ }^{238} U\right.$ ). However, Figure 4 shows that unlike for Kolbeinsey Ridge, there is not a clear systematic relationship between $\left({ }^{234} \mathrm{U} /{ }^{238} \mathrm{U}\right)$ and $\left({ }^{230} \mathrm{Th} /{ }^{238} \mathrm{U}\right)$ for the more northerly ridges. For this reason and because they have relatively high $\left({ }^{230} \mathrm{Th} /{ }^{238} \mathrm{U}\right)$, we consider the ${ }^{230} \mathrm{Th}^{-238} \mathrm{U}$ disequilibrium measurements for samples without measured $\left({ }^{234} \mathrm{U} /{ }^{238} \mathrm{U}\right)$ results at face value.

\subsection{2. ${ }^{238} \mathrm{U}^{230} \mathrm{Th}$}

$\left({ }^{230} \mathrm{Th} /{ }^{238} \mathrm{U}\right.$ ) results are reported in Table 2 (Figure 5) and were measured by PIMMS at WHOI (methods as in (BALL et al., 2008; SIMS et al., 2008)), the University of 
Bristol (methods as in (HoffMANN et al., 2007; Sims et al., 2008)), and the Institute of Geosciences, Kiel University, Kiel, Germany (methods as in (FrETZDORFF et al., 2003)). We plot measured $\left({ }^{238} \mathrm{U} /{ }^{232} \mathrm{Th}\right)$ vs. $\left({ }^{230} \mathrm{Th} /{ }^{232} \mathrm{Th}\right)$ from this study on an "equiline" diagram in Figure 3. As described above, in Chapter 3 we found that lavas from the Kolbeinsey Ridge form a nearly horizontal array that ranges from large ${ }^{230}$ Th excesses to small ${ }^{238} \mathrm{U}$ excesses.

Mohns Ridge samples with age constraints (Table 2; see Section 4.4 below) cluster with a mean ${ }^{230} \mathrm{Th}$ excess of $22 \%$. Knipovich Ridge lavas form a sloped array with $\left({ }^{238} \mathrm{U} /{ }^{232} \mathrm{Th}\right)=0.76 \pm 0.02$ to $0.940 \pm 0.004$ and a slope of 1.0 in Figure 3, and the three samples from the Kolbeinsey Ridge north of $70.6^{\circ} \mathrm{N}$ also form a steep slope (1.9) (Chapter 3). Both the far-north Kolbeinsey Ridge and the Knipovich Ridge data arrays intersect the Mohns Ridge data field. Samples from $85^{\circ} \mathrm{E}$ on the Gakkel Ridge also cluster tightly, and they span a narrow range of $\left({ }^{230} \mathrm{Th} /{ }^{238} \mathrm{U}\right)$ values from $0.95 \pm 0.02$ (small ${ }^{238} \mathrm{U}$ excess) to $1.05 \pm 0.02$ (small ${ }^{230} \mathrm{Th}$ excess).

\subsection{3. ${ }^{230} \mathrm{Th}-{ }^{226} \mathrm{Ra}$}

Though we were sample limited, where possible we measured $\left({ }^{226} \mathrm{Ra} /{ }^{230} \mathrm{Th}\right)$ for our sample suite; all analyses of $\left({ }^{226} \mathrm{Ra}{ }^{230} \mathrm{Th}\right)$ were conducted by PIMMS at WHOI (SIMS et al., 2008). We measured 15 samples with ${ }^{226} \mathrm{Ra}$ excesses (Table 2). Figure 6 shows our $\left({ }^{226} \mathrm{Ra} /{ }^{230} \mathrm{Th}\right)-\left({ }^{230} \mathrm{Th} /{ }^{238} \mathrm{U}\right)$ isotope results together with global data. These data strongly support the negative global correlation described below and in the literature (Sims et al., 2002). Note that without age constraints for the data, these ${ }^{226} \mathrm{Ra}$ excesses are minima (see Section 4.4).

\subsection{4. ${ }^{226} \mathrm{Ra}^{2}{ }^{210} \mathrm{~Pb}$}

We measured ${ }^{210} \mathrm{~Pb}\left(\mathrm{t}_{1 / 2}=22.6 \pm 0.1\right.$ yrs. (Holden, 1990)) by alpha counting of

${ }^{210} \mathrm{Po}$ at the University of Iowa in four fresh, glassy samples from the Gakkel Ridge 
(Table 2). Uncertainties for the alpha counting measurements $(2 \sigma)$ range from $7-11 \%$ (Table 2). Sample Camper $13-1$ has a ${ }^{210} \mathrm{~Pb} \operatorname{deficit}\left(\left({ }^{210} \mathrm{~Pb} /{ }^{226} \mathrm{Ra}\right)=0.89 \pm 9 \%\right)$, and is the only sample out of equilibrium.

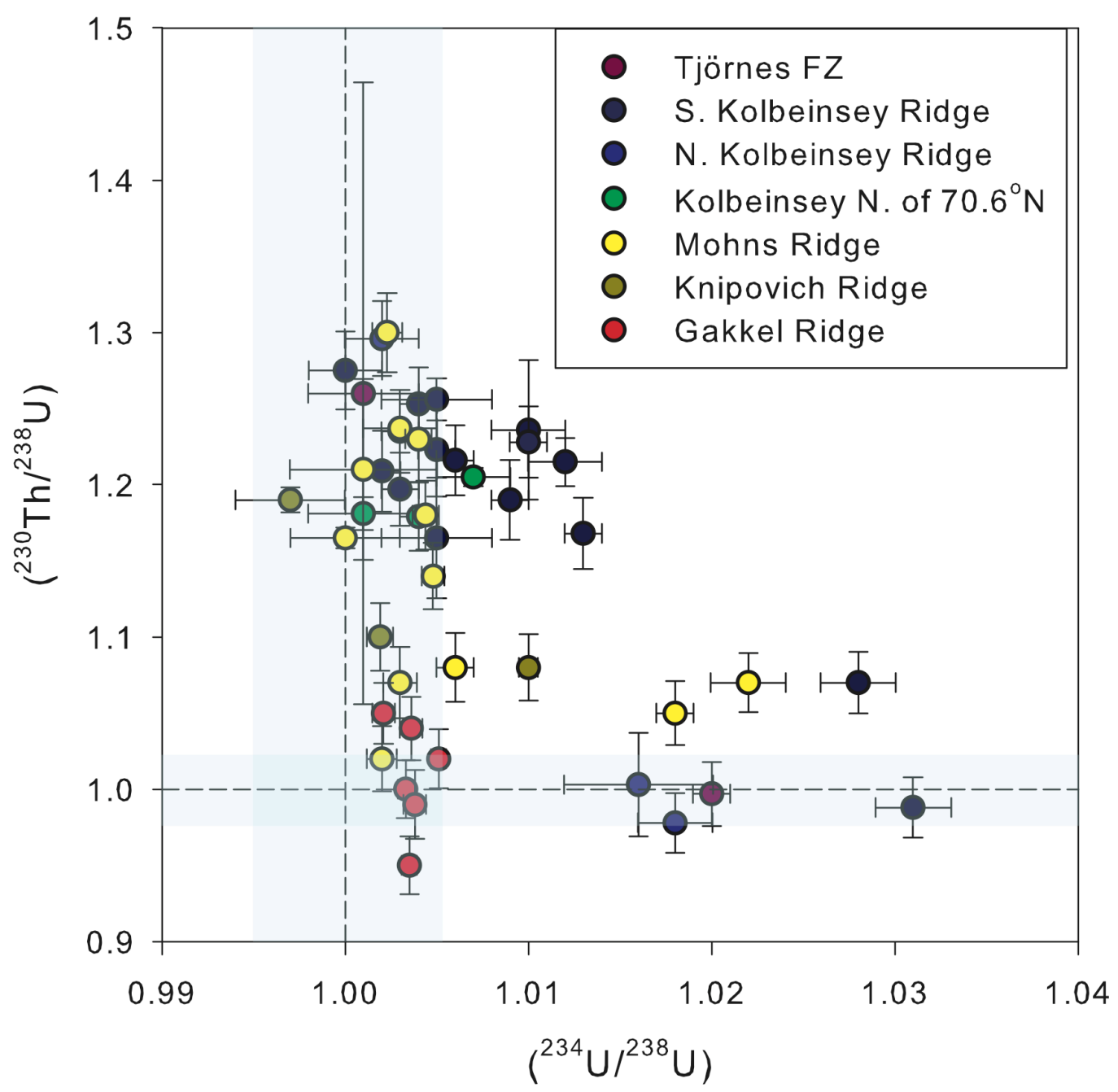

Figure 4. $\left({ }^{234} \mathrm{U} /{ }^{238} \mathrm{U}\right)$ vs. $\left({ }^{230} \mathrm{Th} /{ }^{238} \mathrm{U}\right)$ diagram showing results from Chapters 3 and 4 . Unlike the Kolbeinsey Ridge (Chapter 3), the more northern ridges show less systematic patterns of seawater alteration. 

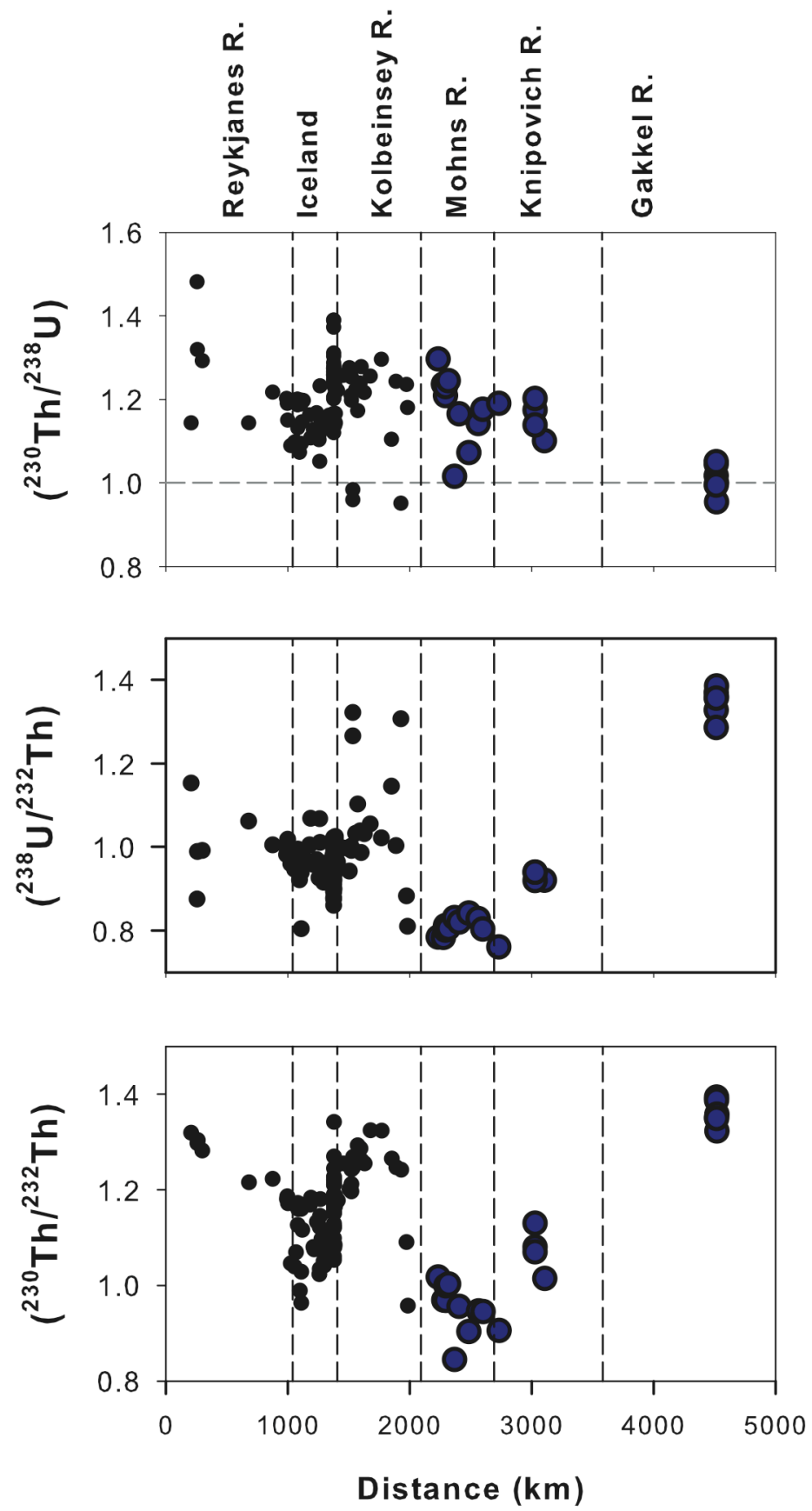

Figure 5. Distance along the Arctic ridge system vs. U-series data in MORB (KOKFELT et al., 2003; PEATE et al., 2001; STRACKE et al., 2003a; STRACKE et al., 2003b). Kolbeinsey Ridge data reported in Chapter 3; new data from this chapter are shown as blue data points. 


\subsubsection{Radiogenic Isotope Analyses}

Isotopic as well as major and trace element data are available from the literature for some of our samples (Blichert-Toft et al., 2005; Hanan et al., 2000; Neumann and Schilling, 1984; Schilling et al., 1999; Schilling et al., 1983; Sigurdsson, 1981; Waggoner, 1989). We measured radiogenic isotopes in those samples that lacked such data (Table 3). Hf and Nd isotope ratios were measured by PIMMS at l'École Normale Supérieure (l'ENS) de Lyon (methods as in (BLICHERT-TOFT, 2001)), and both $\mathrm{Sr}$ and Pb isotope ratios and replicate $\mathrm{Nd}$ isotope ratios were measured by PIMMS at WHOI (SIMS and HART, 2006; TARAS and HART, 1987; TODT et al., 1996; White et al., 2000). Our new results agree well with previous observations for the region (Figure 2; (Blichert-Toft et al., 2005)), and the replicate ${ }^{143} \mathrm{Nd} /{ }^{144} \mathrm{Nd}$ results reported in Table 3 show good interlab agreement within respective uncertainties.

Radiogenic isotopes in Gakkel Ridge lavas from the $85^{\circ} \mathrm{E}$ volcano on the EVZ are homogeneous and depleted (Table 3). In keeping with observations by Goldstein et al. (Goldstein et al., 2008) for EVZ lavas, the $85^{\circ} \mathrm{E}$ samples do not show a DUPAL anomaly, but are instead systematically depleted in all $\mathrm{Pb}$ isotope ratios (e.g. ${ }^{208} \mathrm{~Pb} /{ }^{206} \mathrm{~Pb}=2.087$ 2.093).

\subsection{AGE CONSTRAINTS}

With time, U-series disequilibria undergo radioactive decay that returns systems to a state of secular equilibrium within $\sim 5$ half-lives of the daughter nuclide in question. Thus, age constraints are necessary for correct interpretation of the measured U-series data in MORB. In the absence of age constraints, measured disequilibria can be treated as minimum values only.

As discussed in Chapter 3, Kolbeinsey Ridge lavas erupted through thick glacial outwash sediments and are thus constrained to be younger than the last glacial maximum $(10 \mathrm{ka})$. This is young enough that $\left({ }^{230} \mathrm{Th} /{ }^{238} \mathrm{U}\right)$ disequilibria from Kolbeinsey Ridge can 

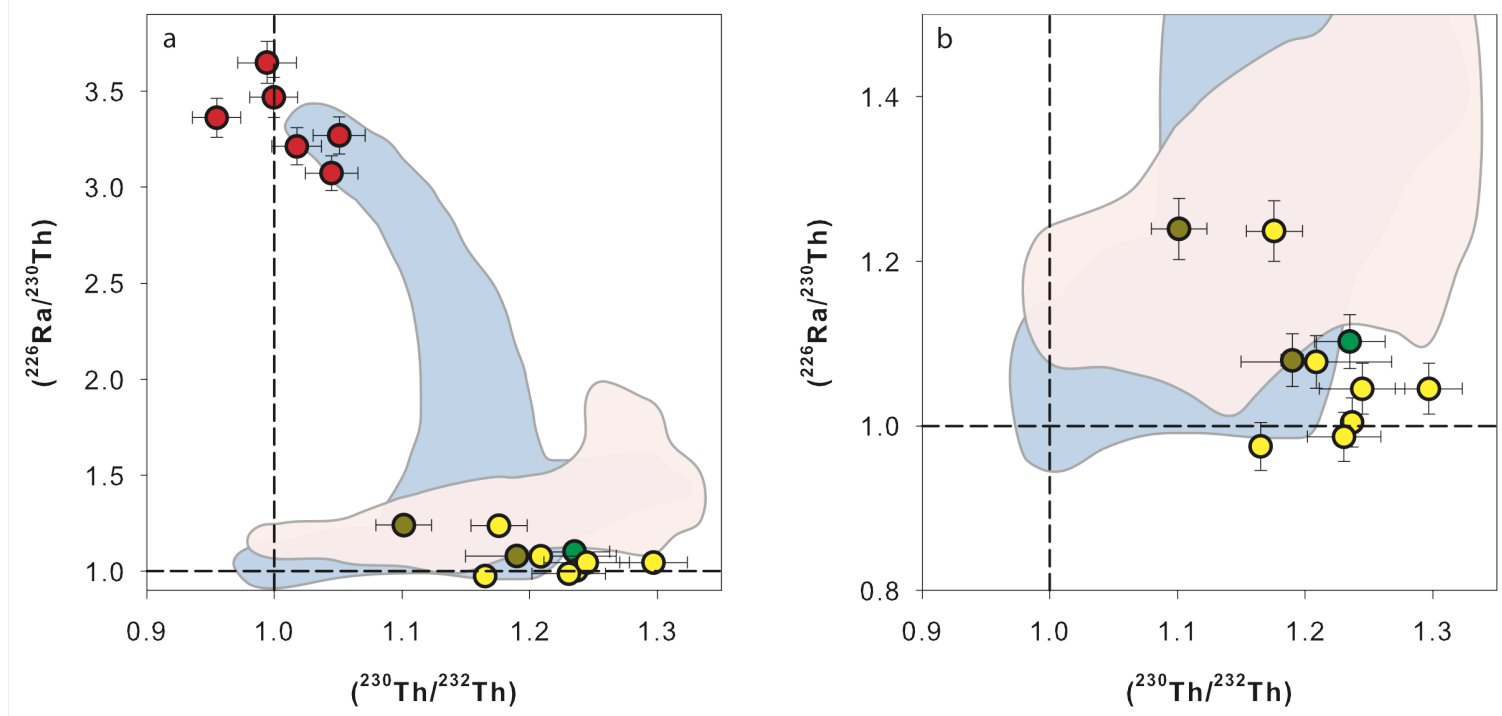

Figure 6. $\left({ }^{226} \mathrm{Ra} /{ }^{230} \mathrm{Th}\right)$ vs. $\left({ }^{230} \mathrm{Th} /{ }^{238} \mathrm{U}\right)$ disequilibria data for this study and Chapter 3 , with global MORB and OIB data (BOURDON et al., 1998; LunDSTROM et al., 1999; PEATE et al., 2001; SIMS et al., 1999a; SIMS et al., 2002; SIMS and HART, 2006; STRACKE et al., 2006; STURM et al., 2000; TEPLEY et al., 2004; TURNER et al., 1997) for comparison. a) Full global data set, and b) scaled to show samples with $\left({ }^{226} \mathrm{Ra} /{ }^{230} \mathrm{Th}\right)$ at or near equilibrium. Symbols as in Figure 3. Global OIB have relatively low ${ }^{226} \mathrm{Ra}$ excesses, while MORB data form a negative correlation that is suggested to indicate mixing of melts from different depths in MOR melting columns (SIMS et al., 2002).

be treated as unperturbed by decay associated with eruption age.

For the new MORB data we report in this study there is no such stratigraphic constraint on eruption age. Where we measure $\left({ }^{226} \mathrm{Ra} /{ }^{230} \mathrm{Th}\right)$ out of equilibrium, we can treat $\left({ }^{230} \mathrm{Th} /{ }^{238} \mathrm{U}\right)$ data as young enough to be unperturbed. Without younger time constraints we must treat all $\left({ }^{226} \mathrm{Ra} /{ }^{230} \mathrm{Th}\right)$ disequilibria as minima. The exception is the sample Camper 13-1 from the Gakkel Ridge, for which we measured a ${ }^{210} \mathrm{~Pb}$ deficit, indicating an eruption age less than 100 years old. That all Gakkel rocks analyzed have similar ${ }^{238} \mathrm{U}_{-}{ }^{230} \mathrm{Th}-{ }^{226} \mathrm{Ra}$ systematics and are very fresh, glassy samples suggests that all of the samples from $85^{\circ} \mathrm{E}$ are similarly young. 


\subsection{ARCTIC MELT GENERATION}

In Chapter 3, we calculated a series of forward model melt trajectories to explore the means by which our measured Kolbeinsey data could be generated by mantle melting processes. We suggested that melting of a relatively homogeneous, depleted, young mantle source in a long melt column could best reproduce the data.

Unlike on the Kolbeinsey Ridge, with its relatively homogeneous source composition, we observe a systematic relationship between isotopic composition and $\left({ }^{230} \mathrm{Th} /{ }^{238} \mathrm{U}\right)$ for the more northerly Knipovich Ridge (Figure 7). Arguably, this relationship may in fact apply to all samples from the Mohns, Knipovich, and far-north Kolbeinsey Ridge, since 1) similar mantle source variations have been suggested for the Mohns and Knipovich Ridges, 2) the Knipovich and far-north Kolbeinsey Ridge arrays form relatively steep slopes (1.0 and 1.9, respectively) and occupy a similar range in $\left({ }^{230} \mathrm{Th}{ }^{232} \mathrm{Th}\right)(0.905-1.130$ and $0.957-1.090$, respectively), and 3$)$ both arrays intersect the relatively enriched Mohns Ridge data. Thus, for at least the Knipovich Ridge lavas, and possibly for all three areas, mantle heterogeneity may play a role in generating U-Th isotope systematics. In Chapter 3 we observed that models that examined melting of two different mantle lithologies (a peridotite and one of two more mafic lithologies, either eclogite or silica-poor garnet pyroxenite) could not reproduce the Kolbeinsey systematics; however, such a scenario may be able to reproduce the Knipovich Ridge, northernmost Kolbeinsey Ridge, and possibly also Mohns Ridge data. The high productivities and deep solidi of mafic lithologies, addressed in Chapters 2 and 3, do not pose a problem for generating steeply sloping arrays by mixing of melts, as shown in Figure 8.

Using the same techniques for two-lithology melting described in detail in Chapter 3, in Figure 8 we plot trajectories for one possible melting and binary melt mixing scenario, in which an enriched, dynamic eclogite melt $\left(\right.$ initial $\left({ }^{238} \mathrm{U} /{ }^{232} \mathrm{Th}\right)=0.6$, similar to a Samoan-type end member (SIMS and HART, 2006)) mixes with the reactive porous flow melt of a depleted peridotite (initial $\left({ }^{238} \mathrm{U} /{ }^{232} \mathrm{Th}\right)=1.25$, as in Chapter 3 ). 

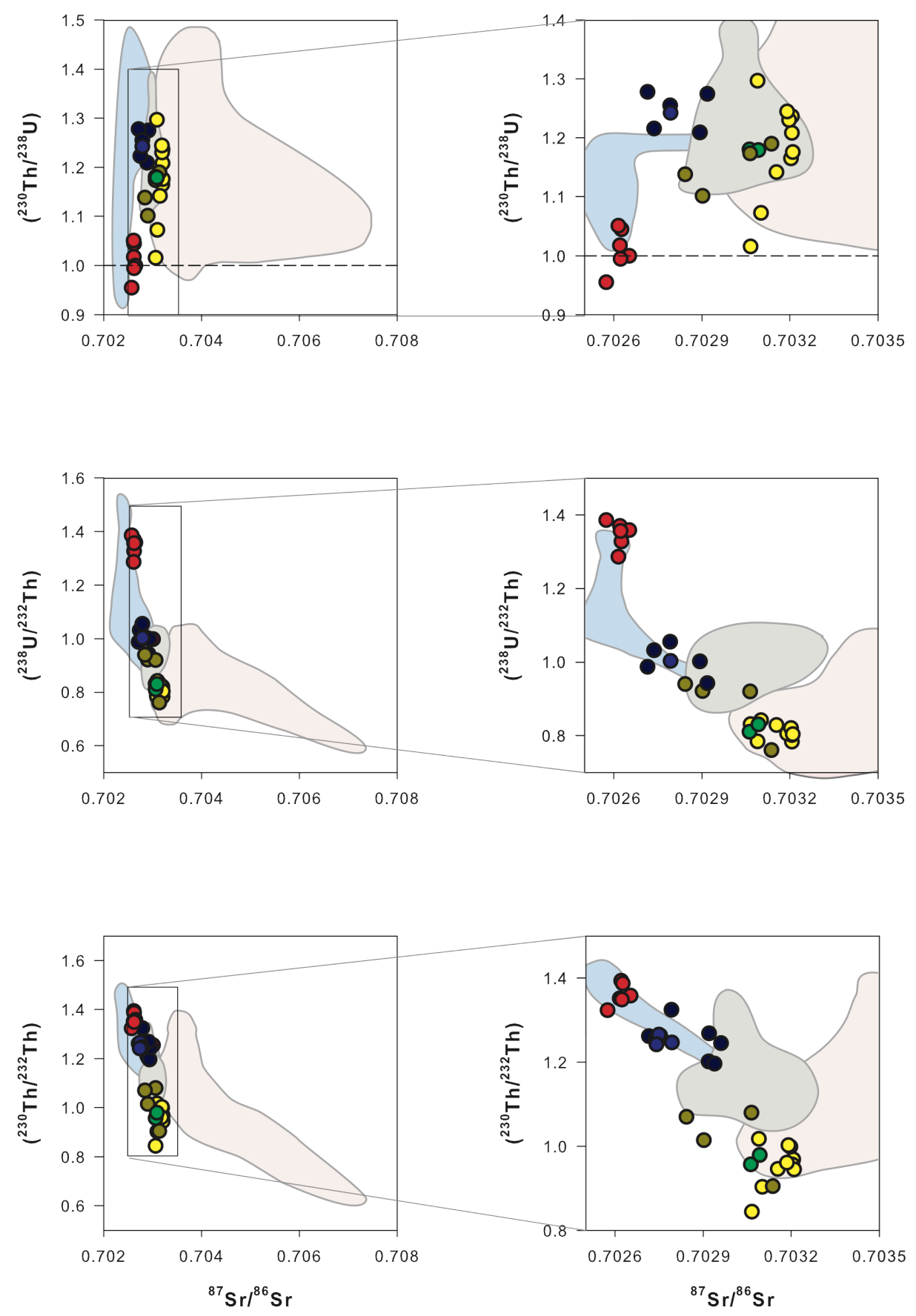

Figure $7 .{ }^{87} \mathrm{Sr} /{ }^{86} \mathrm{Sr}$ vs. $\left({ }^{230} \mathrm{Th} /{ }^{232} \mathrm{Th}\right.$ ) (top panels), $\left({ }^{238} \mathrm{U} /{ }^{232} \mathrm{Th}\right.$ ) (middle panels), and $\left({ }^{230} \mathrm{Th} /{ }^{238} \mathrm{U}\right.$ ) (bottom panels), with symbols as in Figure 3; radiogenic isotope data from this study and the literature (BLICHERT-TOFT et al., 2005; HANAN et al., 2000; NEUMANN and SCHILLING, 1984; SCHILling et al., 1999; SCHILLING et al., 1983; SIGURDSSON, 1981; WAGGONER, 1989). The position on the sloped array for Knipovich Ridge (e.g. $\left({ }^{238} \mathrm{U} /{ }^{232} \mathrm{Th}\right)$ ) does form a correlation, indicating that source composition may control the slope of the array shown in Figure 3. Gakkel Ridge samples are universally isotopically depleted. 
The melting scenario in Figure 8 can readily reproduce the Knipovich Ridge basalts, and a range of different melt models could also produce binary melt mixtures that approximate the Knipovich Ridge array (e.g. mixing melts of depleted and enriched garnet peridotite lithologies. Such compositional heterogeneity agrees with previous suggestions for a heterogeneous mantle underlying the Mohns, Knipovich (BLICHERTTOFT et al., 2005), and Western Gakkel Ridges (Goldstein et al., 2008).

EVZ Gakkel Ridge basalts erupt through thin crust (JOKAT and SCHMIDTAURSCH, 2007), and major element data (e.g. $\mathrm{Na}_{8}$ ) indicate that they are the result of smaller degrees of melting than MORB from the other Arctic ridge segments (Hellebrand et al., 2002). The one sample with measured ${ }^{238} \mathrm{U}$ excess (Camper 23-1) is dominated by relatively shallow melting with no garnet present, and the presence of large ${ }^{226} \mathrm{Ra}$ excesses in all of the $85^{\circ} \mathrm{E}$ samples implies that melt must interact with solid mantle until relatively shallow depths for all samples, and that deep melting in the presence of garnet is minimal. While this indicates a relatively short mantle melting column, even small ${ }^{230}$ Th excesses like those measured in Camper samples 13-1 and 19-1 generally is interpreted to require the presence of garnet. As shown in Elkins et al. (2008), however, spinel peridotites containing clinopyroxene $(\mathrm{Cpx})$ with $\mathrm{M} 2$ site radii smaller than $1.0 \AA$ could plausibly produce small ${ }^{230} \mathrm{Th}$ excesses, though most naturally occurring Cpx for which this is the case are aluminous and occur deep (BEATTIE, 1993a; BEATTIE, 1993b; HAuri et al., 1994; LA TOURETTE and BuRnetT, 1992; LA TOURETTE et al., 1993; LANDWEHR et al., 2001; SALTERS and LONGHI, 1999; SALTERS et al., 2002; WoOD et al., 1999). These ${ }^{230}$ Th excesses, however, are small compared to most MORB. Such ultraslow-spreading ridges are expected to have a thick lithospheric cap, so we envision a short melting column that is capped as far as $50 \mathrm{~km}$ below the surface. The strikingly high $\left({ }^{226} \mathrm{Ra} /{ }^{230} \mathrm{Th}\right)$ values we measure strongly favor shallow mantle-melt interaction for the lavas from $85^{\circ} \mathrm{E}$ Gakkel Ridge. This is supported by the high $\mathrm{MgO}$ contents and high $\mathrm{Na}_{8}$ of Gakkel lavas (Hellebrand et al., 2002; MiCHAEL et al., 2003). 


\subsection{GLOBAL MORB PETROGENESIS}

We compare data from this study with global MORB and OIB data in Figure 6, Figure 8, and Figure 9. Figure 6 shows that the Gakkel Ridge data, with their low $\left({ }^{230} \mathrm{Th} /{ }^{238} \mathrm{U}\right)$ near the equiline and high $\left({ }^{226} \mathrm{Ra} /{ }^{230} \mathrm{Th}\right)$ ranging from 3.07 to $3.65 \pm 3 \%$, corroborate the global inverse trend observed by Sims et al. (2002): the data from this study lie along the negative $\left({ }^{226} \mathrm{Ra} /{ }^{230} \mathrm{Th}\right)-\left({ }^{230} \mathrm{Th} /{ }^{238} \mathrm{U}\right)$ correlation for global MORB. This supports the model that overall MORB are mixtures of deep and shallow (or shallow-reacting) melts in a two-porosity system (JULL et al., 2002; KELEMEN et al., 1997; SIMS et al., 2003; SIMS et al., 1995; SIMS et al., 2002).

In Figure 9a we add data for the sloped Knipovich array to a global compilation of calculated ridge segment slopes. Previously Lundstrom et al. (2003; 1998b) observed a positive trend between spreading rate and slope (excluding FAZAR data because of proximity to the Azores, which implies possible effects of active upwelling), which they suggested arose from binary mixing of enriched and depleted melts in different upwelling regimes. As discussed above, Sims et al. (2002) noted that the data array for $9-10^{\circ} \mathrm{N}$ on the EPR, which seemed to contribute to the positive correlation, was not in fact produced by source heterogeneity. This means that the slope of a MORB array is not solely the product of upwelling rates and mixing of melts from heterogeneous source materials. On the other hand, our new Knipovich Ridge data may be controlled by source heterogeneity; however, the slope is much steeper than that predicted by the correlation observed by Lundstrom et al. (1998b). Even when there is a clear mantle heterogeneity control over the slope of an array on an equiline diagram, the prediction of shallower slopes in regions with slower upwelling does not hold true in all cases. This could reflect the effects of different "enriched" mantle source compositions in different locales, for example. Thus, a combination of factors (initial source compositional variations preserved in the long-lived radiogenic isotope signatures of the melts, as well as progressive source depletion within the melting column) contribute to the slopes 
produced, indicating MORB melting is not simply the result of mixing between melts of heterogeneous sources, as suggested by Lundstrom et al. (2003; 1998b).

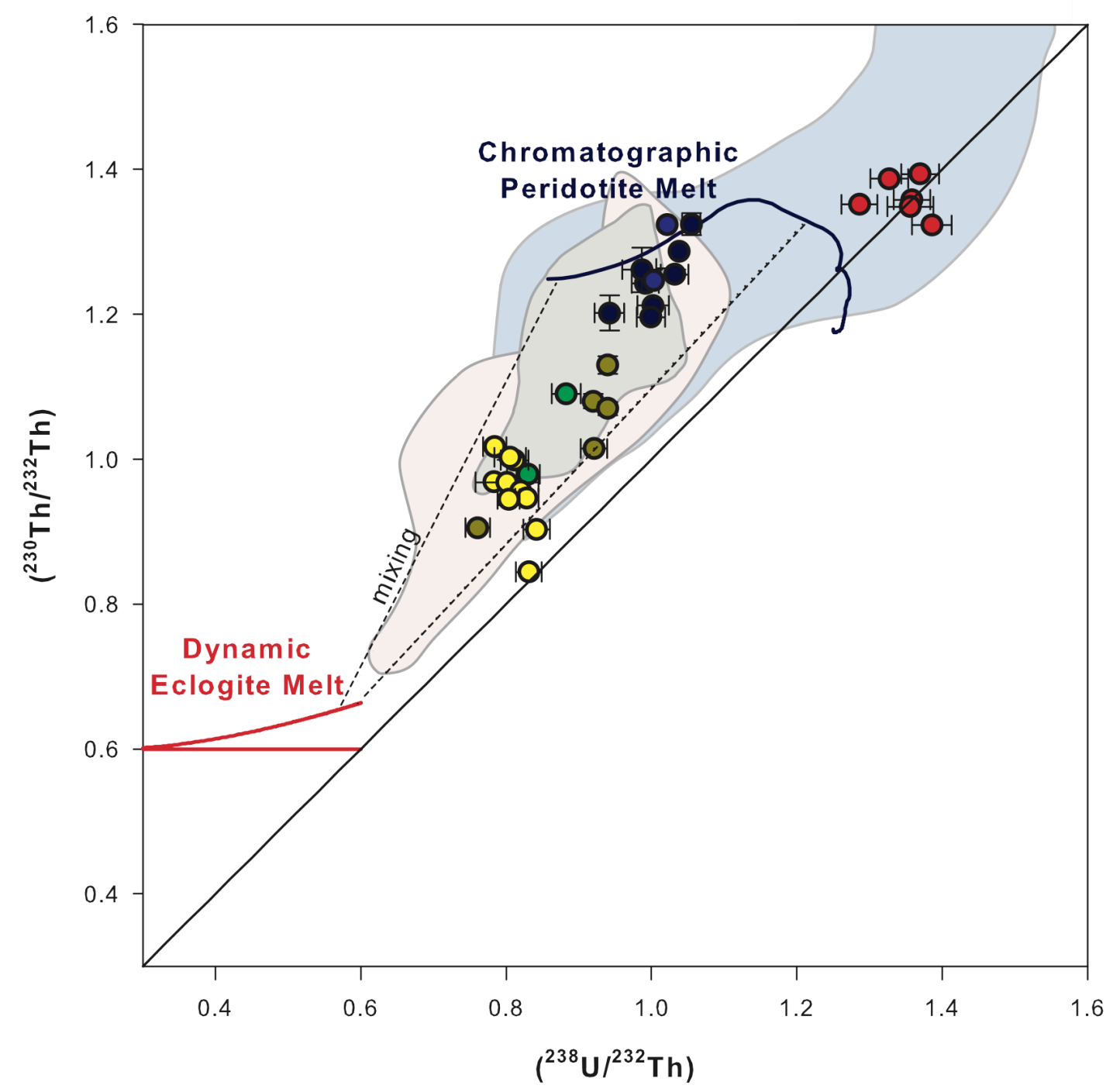

Figure 8. Equiline diagram showing melting model calculations described in Section 5, after Chapter 3. Red line indicates the dynamic melt trajectory for an enriched eclogitic mantle source, and the blue line shows a reactive porous flow garnet peridotite melt. The black dashed lines show possible binary mixtures between these melts $(0.1 \%$ melt of peridotite with $50 \%$ melt of eclogite, and $6 \%$ melt of peridotite with $100 \%$ melt of eclogite). Symbols and fields as in Figure 3. Such a mixing scenario can readily produce the sloped Knipovich and northern Kolbeinsey arrays. A scenario where an enriched peridotite melts instead of an eclogite can also produce plausible mixing trajectories. 
In Figure $9 b$ we plot $\left({ }^{230} \mathrm{Th} /{ }^{238} \mathrm{U}\right)$ vs. axial depth for the global data set, after Bourdon et al. (1996) and Chapter 3. Large data points show the average depth and $\left({ }^{230} \mathrm{Th} /{ }^{238} \mathrm{U}\right)$ for each ridge segment. Overall the negative trend observed and modeled by Bourdon et al. (1996b) is supported by the global data, if the mean $\left({ }^{230} \mathrm{Th} /{ }^{238} \mathrm{U}\right)$ produced is considered to reflect an average depth in the melting column (where length of the column controls the relative amount of melt produced in the garnet stability field). Bourdon et al. (1996b) explained this correlation by inferring a mantle temperature control over melt column depth (i.e. the depth to the peridotite solidus). Thus on average, peridotite melting controls the global production of MORB. That the variance seen at individual ridge segments does not obey the predicted trend suggests that the spread of $\left({ }^{230} \mathrm{Th} /{ }^{238} \mathrm{U}\right)$ data (like the slope of an array) is influenced by factors other than mantle temperature. Mantle heterogeneity is likely one important factor in places like the Knipovich Ridge.

We thus concur with Bourdon et al. (1996b) that mantle temperature and length of peridotitic melt columns, and thus the mean degree of melting, determines the broad, global systematics of ${ }^{238} \mathrm{U}_{-}{ }^{230} \mathrm{Th}$ variations. This encourages us to believe that while minor lithologic heterogeneities surely exist in the mantle and may influence melt composition in some localities, overall MORB production mechanisms are controlled by the melting of peridotite everywhere. Such broad variations are predicted by Sims and Hart (2006), and are a function of the large, variable melt fractions and predicted melting column lengths of MORB, which globally have large $\left({ }^{230} \mathrm{Th} /{ }^{238} \mathrm{U}\right)$ and correspondingly small ${ }^{87} \mathrm{Sr} /{ }^{86} \mathrm{Sr}$ variations, while OIB show the opposite relationship due to their shorter melting columns, lower degrees of melting, and heterogeneous source signatures that overwhelm melt process signals (Figure 10). In keeping with these observations, variations in upwelling rate and mantle compositional variability can affect the variance of measured ${ }^{238} \mathrm{U}_{-}{ }^{230} \mathrm{Th}$ data and the sloped arrays produced on an equiline diagram by individual ridge segments. 


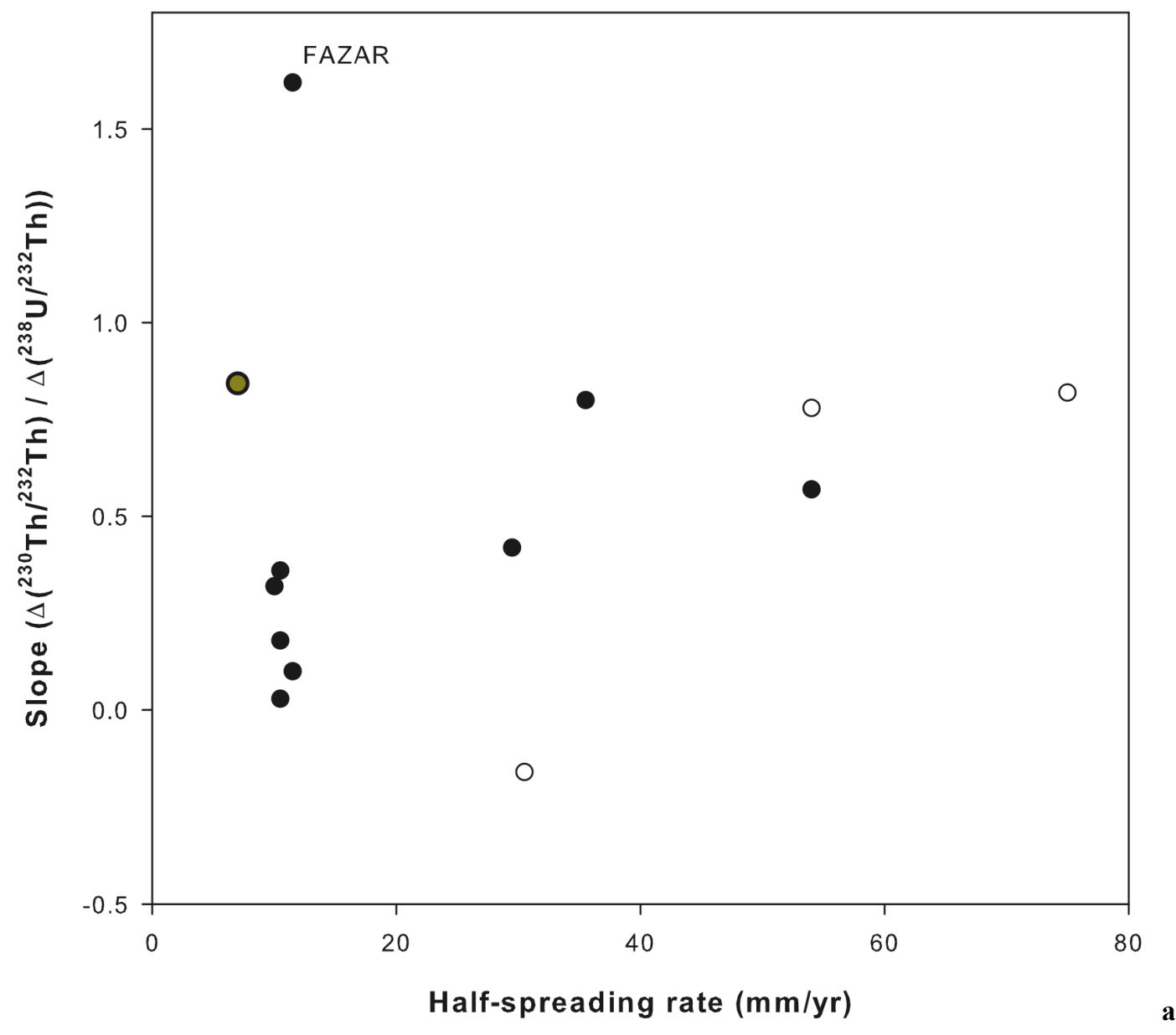



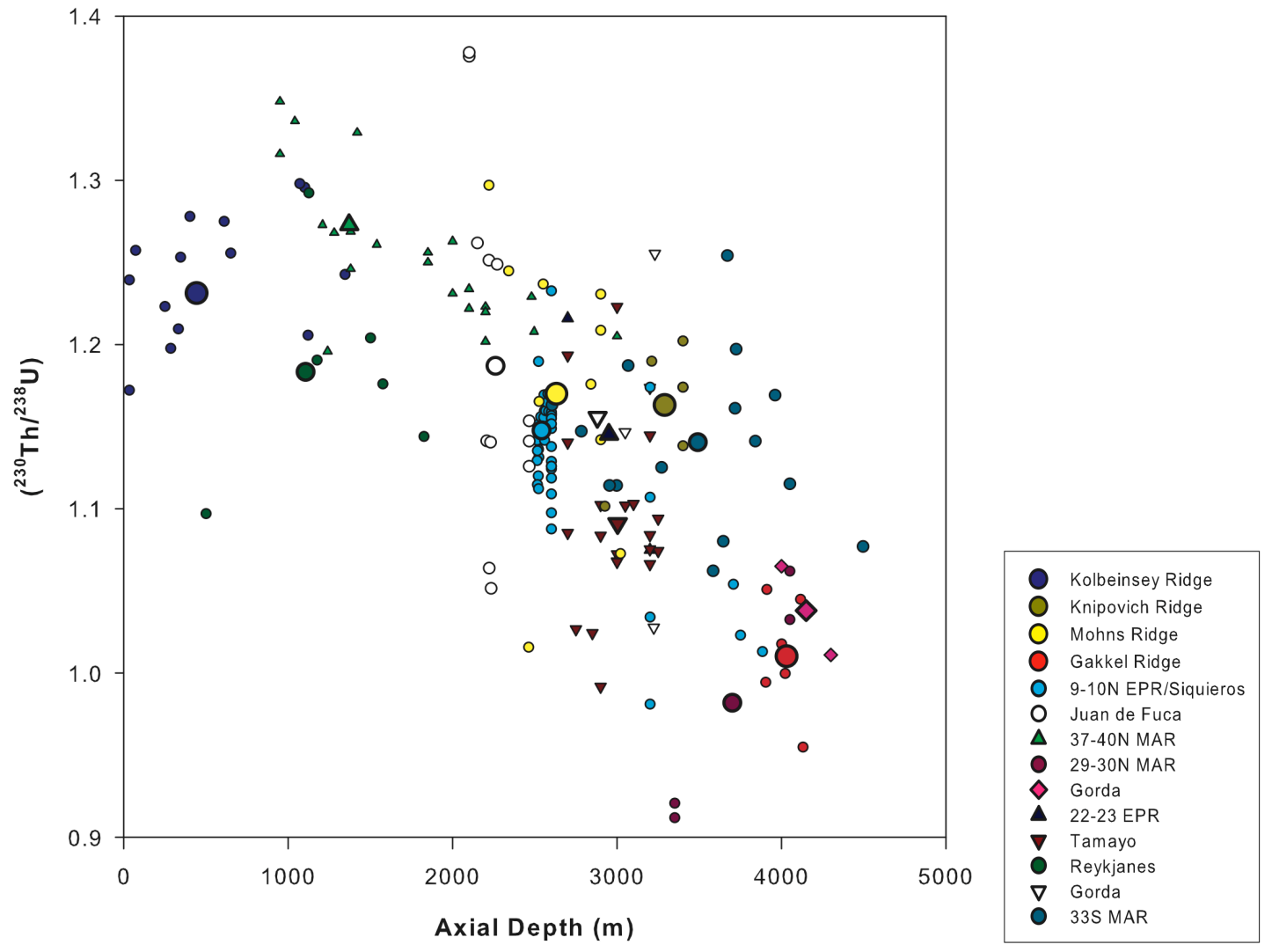

Figure 9. a) Diagram of slopes of arrays on equiline diagrams vs. spreading rates for discrete MOR segments ((LUNDSTROM, 2003) and refs therein), after Lundstrom et al. (1998, 2003). Our new Knipovich array does not agree with the positive correlation previously observed. Open circles indicate alpha counting data, which have larger uncertainties than mass spectrometric data. b) Diagram of measured $\left({ }^{230} \mathrm{Th} /{ }^{238} \mathrm{U}\right)$ vs. axial ridge depth for global ridge data ((BOURDON et al., 1996b; LUNDSTROM, 2003) and refs therein), showing both full data sets (small data points) and ridge averages (larger symbols), after Bourdon et al. (1996). The trend for mean ridge data supports the suggestion by Bourdon et al. (1996) that regional mantle temperature controls depth of peridotite melting and $\left({ }^{230} \mathrm{Th} /{ }^{238} \mathrm{U}\right)$, but the variations of individual ridge segments are influenced by other factors and do not as clearly follow this trend. This likely reflects variable sampling of deep and shallow melts in two-porosity systems, coupled with variations in the amount of mixing in magma chambers. 


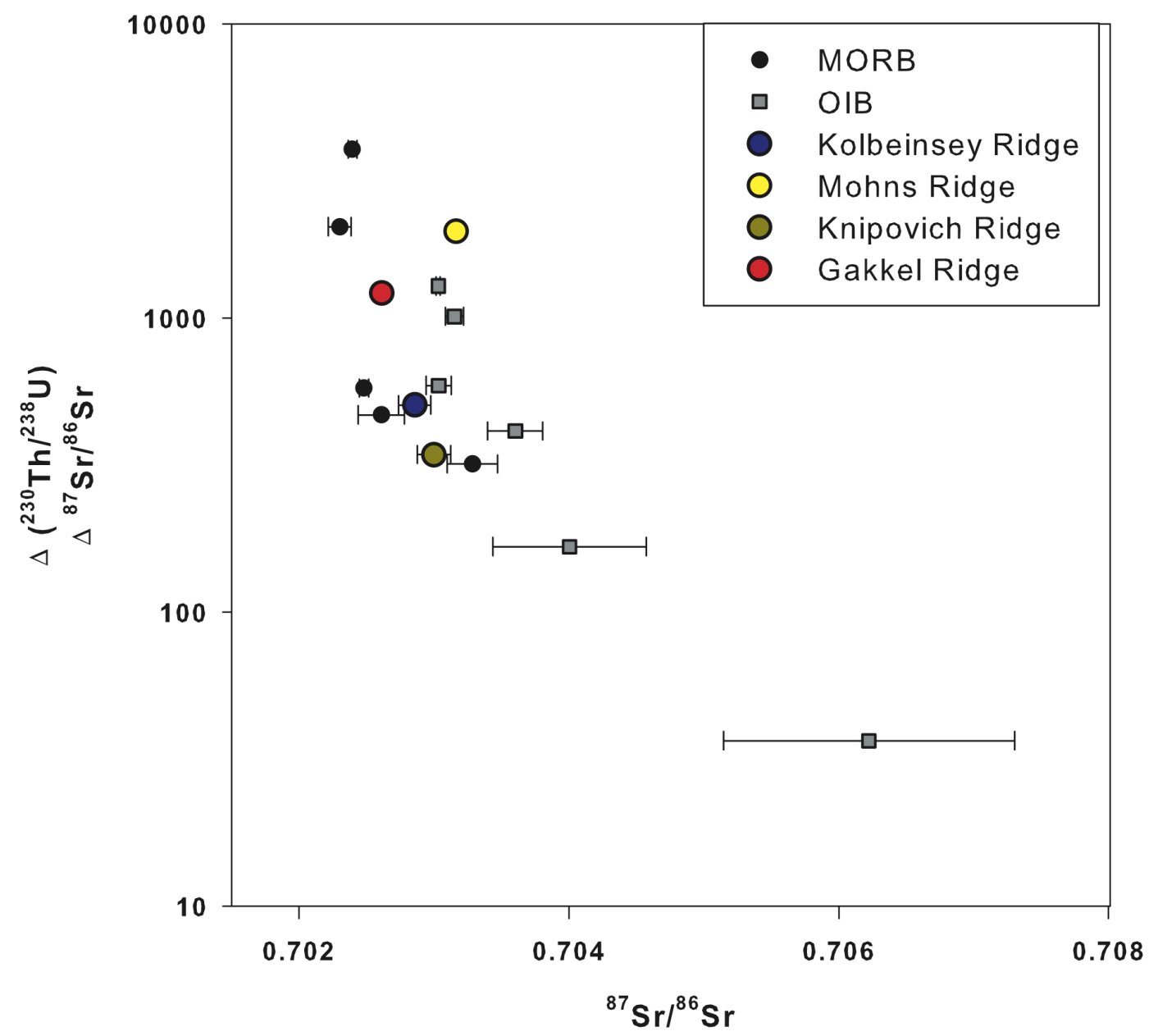

Figure 10. Diagram showing the ratio of the ranges of $\left({ }^{230} \mathrm{Th} /{ }^{238} \mathrm{U}\right)$ and ${ }^{87} \mathrm{Sr} /{ }^{86} \mathrm{Sr}$ data vs. mean ${ }^{87} \mathrm{Sr} /{ }^{86} \mathrm{Sr}$ for MOR segments (black circles) and OIB settings, including Iceland (gray squares; (SIMS and HART, 2006) and references therein), with data from the four Arctic Ridges from this study and Chapter 3. Error bars show $1 \sigma$ standard deviations for ${ }^{87} \mathrm{Sr} /{ }^{86} \mathrm{Sr}$ data from individual MOR and OIB locales. Global MORB, including data from this study, have greater ranges of disequilibria and correspondingly smaller variations in radiogenic isotopes than OIB.

\subsection{CONCLUSIONS}

In Chapter 3 we found that MORB from the Kolbeinsey Ridge north of Iceland have universally high ${ }^{230}$ Th excesses which are best explained by a deep peridotite melt column and a young, depleted, relatively homogeneous mantle source that experiences a 
large degree of melting to produce the thick crust and observed major element systematics of the lavas.

Here we find that basalts from $85^{\circ} \mathrm{E}$ on the Gakkel Ridge are highly homogeneous and have low $\left({ }^{230} \mathrm{Th} /{ }^{238} \mathrm{U}\right)$ ranging from $5 \%{ }^{230} \mathrm{Th}$ excess to $5 \%{ }^{238} \mathrm{U}$ excess, with large $\left.{ }^{226} \mathrm{Ra}{ }^{230} \mathrm{Th}\right)$ ratios, all greater than 3 . These samples lie on the negative global correlation between $\left({ }^{226} \mathrm{Ra} /{ }^{230} \mathrm{Th}\right)$ and $\left({ }^{230} \mathrm{Th} /{ }^{238} \mathrm{U}\right)$ observed by Sims et al. (2002), indicating that the Gakkel MORB are the result of mixing of melts extracted from different depths during upwelling.

MORB from the Kolbeinsey Ridge immediately adjacent to the Jan Mayen FZ, from the Mohns Ridge, and from the Knipovich Ridge are more isotopically enriched than either the Kolbeinsey or Gakkel Ridge lavas. Far-north Kolbeinsey and Knipovich basalts form sloped arrays on an equiline diagram that intersect the relatively enriched Mohns Ridge data. We observe a correlation between position on the sloped arrays (e.g. $\left.\left({ }^{238} \mathrm{U} /{ }^{232} \mathrm{Th}\right)\right)$ and radiogenic isotopic composition (e.g. ${ }^{87} \mathrm{Sr} /{ }^{86} \mathrm{Sr}$ ), suggesting that ${ }^{238} \mathrm{U}$ ${ }^{230} \mathrm{Th}$ data in these MORB are controlled by heterogeneity in the mantle source, unlike the majority of Kolbeinsey Ridge lavas or MORB from $85^{\circ} \mathrm{E}$ on the Gakkel Ridge. This heterogeneity likely reflects the presence of trapped subcontinental lithospheric material in the subsurface beneath these ridges (BLICHERT-TOFT et al., 2005). Despite this source heterogeneity control, the slope of the data array is steeper than that predicted by Lundstrom et al. (1998b), suggesting that the relationship they predicted for array slopes and upwelling rates does not sufficiently account for global source compositional variations.

We argue that global MORB $\left({ }^{230} \mathrm{Th} /{ }^{238} \mathrm{U}\right)$ is controlled, on average, by mantle temperature and, thus, by the depth of peridotite melting, as suggested by Bourdon et al. (1996b). The range of $\left({ }^{230} \mathrm{Th} /{ }^{238} \mathrm{U}\right)$ observed and slope on an equiline diagram, however, is affected by factors such as progressive source depletion in a two-porosity melting regime, the presence as well as the compositional range of isotopic and/or lithologic heterogeneities in the source, and variable mixing in crustal magma chambers. 


\section{References}

Ball, L., Sims, K. W. W., and Schwieters, J., 2008. Measurement of U-234/U-238 and Th-230/Th-232 in volcanic rocks using the Neptune MC-ICP-MS. Journal of Analytical Atomic Spectrometry 23, 173-180.

Beattie, P., 1993a. The Generation of Uranium Series Disequilibria by Partial Melting of Spinel Peridotite - Constraints from Partitioning Studies. Earth Planet Sc Lett 117, 379-391.

Beattie, P., 1993b. Uranium Thorium Disequilibria and Partitioning on Melting of Garnet Peridotite. Nature 363, 63-65.

Blichert-Toft, J., 2001. On the Lu-Hf isotope geochemistry of silicate rocks. Geostandards Newsletter-the Journal of Geostandards and Geoanalysis 25, 4156.

Blichert-Toft, J., Agranier, A., Andres, M., Kingsley, R., Schilling, J. G., and Albarede, F., 2005. Geochemical segmentation of the Mid-Atlantic Ridge north of Iceland and ridge-hot spot interaction in the North Atlantic. Geochem Geophy Geosy 6, -

Bourdon, B., Joron, J. L., Claude-Ivanaj, C., and Allegre, C. J., 1998. U-Th-Pa-Ra systematics for the Grande Comore volcanics: melting processes in an upwelling plume. Earth Planet Sc Lett 164, 119-133.

Bourdon, B., Langmuir, C. H., and Zindler, A., 1996a. Ridge-hotspot interaction along the Mid-Atlantic Ridge between 37 degrees 30' and 40 degrees $30 ' \mathrm{~N}$ : The U-Th disequilibrium evidence. Earth Planet Sc Lett 142, 175-189.

Bourdon, B., Zindler, A., Elliott, T., and Langmuir, C. H., 1996b. Constraints on mantle melting at mid-ocean ridges from global U-238-Th-230 disequilibrium data. Nature 384, 231-235.

Breivik, A. J., Mjelde, R., Faleide, J. I., and Murai, Y., 2006. Rates of continental breakup magmatism and seafloor spreading in the Norway Basin-Iceland plume interaction. J Geophys Res-Sol Ea 111, -.

Claude-Ivanaj, C., Bourdon, B., and Allegre, C. J., 1998. Ra-Th-Sr isotope systematics in Grande Comore Island: a case study of plume-lithosphere interaction. Earth Planet Sc Lett 164, 99-117.

Claude-Ivanaj, C., Joron, J. L., and Allegre, C. J., 2001. U-238-Th-230-Ra-226 fractionation in historical lavas from the Azores: long-lived source heterogeneity vs. metasomatism fingerprints. Chem Geol 176, 295-310.

Cohen, R. S., Evensen, N. M., Hamilton, P. J., and Onions, R. K., 1980. U-Pb, Sm-Nd and Rb-Sr Systematics of Mid-Ocean Ridge Basalt Glasses. Nature 283, 149-153.

Condomines, M., Morand, P., Allegre, C. J., and Sigvaldason, G., 1981. Th-230-U-238 Disequilibria in Historical Lavas from Iceland. Earth Planet Sc Lett 55, 393-406.

Devey, C. W., Garbeschonberg, C. D., Stoffers, P., Chauvel, C., and Mertz, D. F., 1994. Geochemical Effects of Dynamic Melting beneath Ridges - Reconciling Major and Trace-Element Variations in Kolbeinsey (and Global) Midocean Ridge Basalt. J Geophys Res-Sol Ea 99, 9077-9095. 
Dupre, B. and Allegre, C. J., 1980. Pb-Sr-Nd Isotopic Correlation and the Chemistry of the North-Atlantic Mantle. Nature 286, 17-22.

Elkins, L. J., Gaetani, G. A., and Sims, K. W. W., 2008. Partitioning of U and Th during garnet pyroxenite partial melting: Constraints on the source of alkaline ocean island basalts. Earth Planet Sc Lett 265, 270-286.

Fretzdorff, S., Haase, K. M., Leat, P. T., Livermore, R. A., Garbe-Schonberg, C. D., Fietzke, J., and Stoffers, P., 2003. Th-230-U-238 disequilibrium in East Scotia backarc basalts: Implications for slab contributions. Geology 31, 693-696.

Furman, T., Frey, F. A., and Park, K. H., 1991. Chemical Constraints on the Petrogenesis of Mildly Alkaline Lavas from Vestmannaeyjar, Iceland - the Eldfell (1973) and Surtsey (1963-1967) Eruptions. Contrib Mineral Petr 109, 19-37.

Glebovsky, V. Y., Kaminsky, V. D., Minakov, A. N., Merkur'ev, S. A., Childers, V. A., and Brozena, J. M., 2006. Formation of the Eurasia Basin in the arctic ocean as inferred from geohistorical analysis of the anomalous magnetic. Geotectonics $\mathbf{4 0}$, 263-281.

Goldstein, S. J., Murrell, M. T., and Jackecky, D. R., 1989. Th and U isotopic systematics of basalts from the Juan de Fuca and Gorda Ridges by mass spectrometry. Earth Planet Sc Lett 96, 134-146.

Goldstein, S. J., Murrell, M. T., Janecky, D. R., Delaney, J. R., and Clague, D. A., 1992. Geochronology and Petrogenesis of Morb from the Juan-De-Fuca and Gorda Ridges by U-238 Th-230 Disequilibrium. Earth Planet Sc Lett 109, 255-272.

Goldstein, S. J., Murrell, M. T., and Williams, R. W., 1993. Pa-231 and Th-230 Chronology of Midocean Ridge Basalts. Earth Planet Sc Lett 115, 151-159.

Goldstein, S. L., Soffer, G., Langmuir, C. H., Lehnert, K. A., Graham, D. W., and Michael, P. J., 2008. Origin of a 'Southern Hemisphere' geochemical signature in the Arctic upper mantle. Nature 453, 89-U5.

Haase, K. M., Devey, C. W., Mertz, D. F., Stoffers, P., and GarbeSchonberg, D., 1996. Geochemistry of lavas from Mohns ridge, Norwegian-Greenland Sea: Implications for melting conditions and magma sources near Jan Mayen. Contrib Mineral Petr 123, 223-237.

Haase, K. M., Devey, C. W., and Wieneke, M., 2003. Magmatic processes and mantle heterogeneity beneath the slow-spreading northern Kolbeinsey Ridge segment, North Atlantic. Contrib Mineral Petr 144, 428-448.

Hanan, B. B., Blichert-Toft, J., Kingsley, R., and Schilling, J. G., 2000. Depleted Iceland mantle plume geochemical signature: artifact of multicomponent mixing? Geochem Geophy Geosy 1.

Hardarson, B. S. and Fitton, J. G., 1997. Mechanisms of crustal accretion in Iceland. Geology 25, 1043-1046.

Hards, V. L., Kempton, P. D., and Thompson, R. N., 1995. The Heterogeneous Iceland Plume - New Insights from the Alkaline Basalts of the Snaefell Volcanic Center. $J$ Geol Soc London 152, 1003-1009.

Hart, S. R., Hauri, E. H., Oschmann, L. A., and Whitehead, J. A., 1992. Mantle Plumes and Entrainment - Isotopic Evidence. Science 256, 517-520. 
Hauri, E. H., Wagner, T. P., and Grove, T. L., 1994. Experimental and Natural Partitioning of Th, U, $\mathrm{Pb}$ and Other Trace-Elements between Garnet, Clinopyroxene and Basaltic Melts. Chemical Geology 117, 149-166.

Hellebrand, E., Snow, J. E., and Muhe, R., 2002. Mantle melting beneath Gakkel Ridge (Arctic Ocean): abyssal peridotite spinel compositions. Chemical Geology 182, 227-235.

Hemond, C., Arndt, N. T., Lichtenstein, U., Hofmann, A. W., Oskarsson, N., and Steinthorsson, S., 1993. The Heterogeneous Iceland Plume - Nd-Sr-O Isotopes and Trace-Element Constraints. J Geophys Res-Sol Ea 98, 15833-15850.

Henderson, G. M., Cohen, A. S., and Onions, R. K., 1993. U-234/U-238 Ratios and Th230 Ages for Hateruma Atoll Corals - Implications for Coral Diagenesis and Seawater U-234/U-238 Ratios. Earth Planet Sc Lett 115, 65-73.

Hilton, D. R., Thirlwall, M. F., Taylor, R. N., Murton, B. J., and Nichols, A., 2000. Controls on magmatic degassing along the Reykjanes Ridge with implications for the helium paradox. Earth Planet Sc Lett 183, 43-50.

Hoffmann, D. L., Prytulak, J., Richards, D. A., Elliott, T., Coath, C. D., Smart, P. L., and Scholz, D., 2007. Procedures for accurate U and Th isotope measurements by high precision MC-ICPMS. International Journal of Mass Spectrometry 264, 97 109.

Holden, N. E., 1990. Total Half-Lives for Selected Nuclides. Pure and Applied Chemistry 62, 941-958.

Jakobsson, M., Macnab, R., Mayer, L., Anderson, R., Edwards, M., Hatzky, J., Schenke, H. W., and Johnson, P., 2008. An improved bathymetric portrayal of the Arctic Ocean: Implications for ocean modeling and geological, geophysical and oceanographic analyses. Geophysical Research Letters 35, -.

Jokat, W. and Schmidt-Aursch, M. C., 2007. Geophysical characteristics of the ultraslow spreading Gakkel Ridge, Arctic Ocean. Geophysical Journal International 168, 983-998.

Jull, M., Kelemen, P., and Sims, K., 2002. Consequences of diffuse and channelled porous melt migration on uranium series disequilibria. Geochim Cosmochim Ac 66, A719-A719.

Kandilarov, A., Mjelde, R., Okino, K., and Murai, Y., 2008. Crustal structure of the ultraslow spreading Knipovich Ridge, North Atlantic, along a presumed amagmatic portion of oceanic crustal formation. Mar Geophys Res 29, 109-134.

Kelemen, P. B., Hirth, G., Shimizu, N., Spiegelman, M., and Dick, H. J. B., 1997. A review of melt migration processes in the adiabatically upwelling mantle beneath oceanic spreading ridges. Philosophical Transactions of the Royal Society of London Series a-Mathematical Physical and Engineering Sciences 355, 283-318.

Klein, E. M. and Langmuir, C. H., 1987. Global Correlations of Ocean Ridge Basalt Chemistry with Axial Depth and Crustal Thickness. J Geophys Res-Solid 92, 8089-8115.

Klingelhofer, F., Geli, L., and White, R. S., 2000. Geophysical and geochemical constraints on crustal accretion at the very-slow spreading Mohns Ridge. Geophysical Research Letters 27, 1547-1550. 
Kodaira, S., Mjelde, R., Gunnarsson, K., Shiobara, H., and Shimamura, H., 1997. Crustal structure of the Kolbeinsey Ridge, North Atlantic, obtained by use of ocean bottom seismographs. J Geophys Res-Sol Ea 102, 3131-3151.

Kokfelt, T. F., Hoernle, K., and Hauff, F., 2003. Upwelling and melting of the Iceland plume from radial variation of U-238-Th-230 disequilibria in postglacial volcanic rocks. Earth Planet Sc Lett 214, 167-186.

Ku, T. L., Knauss, K. G., and Mathieu, G. G., 1977. Uranium in Open Ocean Concentration and Isotopic Composition. Deep-Sea Research 24, 1005-1017.

La Tourette, T. Z. and Burnett, D. S., 1992. Experimental determination of U-partitioning and Th-partitioning between cpx and natural and synthetic basaltic liquid. Earth Planet Sc Lett 110, 227-244.

La Tourette, T. Z., Kennedy, A. K., and Wasserburg, G. J., 1993. Thorium-uranium fractionation by garnet: Evidence for a deep source and rapid rise of oceanic basalts. Science 261, 729-742.

Landwehr, D., Blundy, J., Chamorro-Perez, E. M., Hill, E., and Wood, B., 2001. U-series disequilibria generated by partial melting of spinel lherzolite. Earth Planet Sc Lett 188, 329-348.

Ljones, F., Kuwano, A., Mjelde, R., Breivik, A., Shimamura, H., Murai, Y., and Nishimura, Y., 2004. Crustal transect from the North Atlantic Knipovich Ridge to the Svalbard margin west of hornsund. Tectonophysics 378, 17-41.

Lundstrom, C., 2000. Models of U-series disequilibria generation in MORB: the effects of two scales of melt porosity. Phys Earth Planet In 121, 189-204.

Lundstrom, C. C., 2003. Uranium-series disequilibria in mid-ocean ridge basalts: Observations and models of basalt genesis. Rev Mineral Geochem 52, 175-214.

Lundstrom, C. C., Gill, J., Williams, Q., and Hanan, B. B., 1998a. Investigating solid mantle upwelling beneath mid-ocean ridges using U-series disequilibria. II. A local study at 33 degrees Mid-Atlantic Ridge. Earth Planet Sc Lett 157, 167-181.

Lundstrom, C. C., Sampson, D. E., Perfit, M. R., Gill, J., and Williams, Q., 1999. Insights into mid-ocean ridge basalt petrogenesis: U-series disequilibria from the Siqueiros Transform, Lamont Seamounts, and East Pacific Rise. J Geophys Res-Sol Ea 104, 13035-13048.

Lundstrom, C. C., Williams, Q., and Gill, J. B., 1998b. Investigating solid mantle upwelling rates beneath mid-ocean ridges using U-series disequilibria, 1: a global approach. Earth Planet Sc Lett 157, 151-165.

Mertz, D. F., Devey, C. W., Todt, W., Stoffers, P., and Hofmann, A. W., 1991. Sr-Nd-Pb Isotope Evidence against Plume Asthenosphere Mixing North of Iceland. Earth Planet Sc Lett 107, 243-255.

Mertz, D. F. and Haase, K. M., 1997. The radiogenic isotope composition of the highlatitude North Atlantic mantle. Geology 25, 411-414.

Mertz, D. F., Sharp, W. D., and Haase, K. M., 2004. Volcanism on the Eggvin Bank (Central Norwegian-Greenland Sea, latitude similar to 71 degrees N): age, source, and relationship to the Iceland and putative Jan Mayen plumes. $J$ Geodyn 38, 5783. 
Michael, P. J., Langmuir, C. H., Dick, H. J. B., Snow, J. E., Goldstein, S. L., Graham, D. W., Lehnert, K., Kurras, G., Jokat, W., Muhe, R., and Edmonds, H. N., 2003. Magmatic and amagmatic seafloor generation at the ultraslow-spreading Gakkel ridge, Arctic Ocean. Nature 423, 956-U1.

Mjelde, R., Breivik, A. J., Raum, T., Mittelstaedt, E., Ito, G., and Faleide, J. I., 2008a. Magmatic and tectonic evolution of the North Atlantic. J Geol Soc London 165, 31-42.

Mjelde, R., Raum, T., Breivik, A. J., and Faleide, J. I., 2008b. Crustal transect across the North Atlantic. Mar Geophys Res 29, 73-87.

Mosar, J., Lewis, G., and Torsvik, T. H., 2002. North Atlantic sea-floor spreading rates: implications for the Tertiary development of inversion structures of the Norwegian-Greenland Sea. J Geol Soc London 159, 503-515.

Murton, B. J., Taylor, R. N., and Thirlwall, M. F., 2002. Plume-ridge interaction: A geochemical perspective from the Reykjanes Ridge. J Petrol 43, 1987-2012.

Neumann, E. R. and Schilling, J. G., 1984. Petrology of Basalts from the MohnsKnipovich Ridge - the Norwegian-Greenland Sea. Contrib Mineral Petr 85, 209223.

O'Nions, R. K. and Pankhurs.Rj, 1973. Secular Variation in Sr-Isotope Composition of Icelandic Volcanic-Rocks. Earth Planet Sc Lett 21, 13-21.

Okino, K., Curewitz, D., Asada, M., Tamaki, K., Vogt, P., and Crane, K., 2002. Preliminary analysis of the Knipovich Ridge segmentation: influence of focused magmatism and ridge obliquity on an ultraslow spreading system. Earth Planet Sc Lett 202, 275-288.

Peate, D. W., Hawkesworth, C. J., van Calsteren, P. W., Taylor, R. N., and Murton, B. J., 2001. U-238-Th-230 constraints on mantle upwelling and plume-ridge interaction along the Reykjanes Ridge. Earth Planet Sc Lett 187, 259-272.

Pietruszka, A. J., Rubin, K. H., and Garcia, M. O., 2001. Ra-226-Th-230-U-238 disequilibria of historical Kilauea lavas (1790-1982) and the dynamics of mantle melting within the Hawaiian plume. Earth Planet Sc Lett 186, 15-31.

Poreda, R., Schilling, J. G., and Craig, H., 1986. Helium and Hydrogen Isotopes in Ocean-Ridge Basalts North and South of Iceland. Earth Planet Sc Lett 78, 1-17.

Salters, V. J. M. and Longhi, J., 1999. Trace element partitioning during the initial stages of melting beneath mid-ocean ridges. Earth Planet Sc Lett 166, 15-30.

Salters, V. J. M., Longhi, J. E., and Bizimis, M., 2002. Near mantle solidus trace element partitioning at pressures up to $3.4 \mathrm{GPa}$. Geochem Geophy Geosy 3, -

Salters, V. J. M. and White, W. M., 1998. Hf isotope constraints on mantle evolution. Chem Geol 145, 447-460.

Schilling, J. G., 1975. Rare-Earth Variations across Normal-Segments of Reykjanes Ridge, 60degrees-53degreesn N, Mid-Atlantic Ridge, 29degreess S, and East Pacific Rise, 2degrees-19degreess S, and Evidence on Composition of Underlying Low-Velocity Layer. J Geophys Res 80, 1459-1473.

Schilling, J. G., Kingsley, R., Fontignie, D., Poreda, R., and Xue, S., 1999. Dispersion of the Jan Mayen and Iceland mantle plumes in the Arctic: A He-Pb-Nd-Sr isotope 
tracer study of basalts from the Kolbeinsey, Mohns, and Knipovich Ridges. $J$ Geophys Res-Sol Ea 104, 10543-10569.

Schilling, J. G., Zajac, M., Evans, R., Johnston, T., White, W., Devine, J. D., and Kingsley, R., 1983. Petrologic and Geochemical Variations Along the MidAtlantic Ridge from 29-Degrees-N to 73-Degrees-N. Am J Sci 283, 510-586.

Shipilov, E. V., 2008. Generations of spreading basins and stages of breakdown of Wegener's pangea in the geodynamic evolution of the Arctic Ocean. Geotectonics 42, 105-124.

Sigmarsson, O., Carn, S., and Carracedo, J. C., 1998. Systematics of U-series nuclides in primitive lavas from the 1730-36 eruption on Lanzarote, Canary Islands, and implications for the role of garnet pyroxenites during oceanic basalt formations. Earth Planet Sc Lett 162, 137-151.

Sigurdsson, H., 1981. 1st-Order Major Element Variation in Basalt Glasses from the Mid-Atlantic Ridge - 29-Degrees-N to 73-Degrees-N. J Geophys Res 86, 94839502.

Sims, K. W. W., Blichert-Toft, J., Fornari, D. J., Perfit, M. R., Goldstein, S. J., Johnson, P., DePaolo, D. J., Hart, S. R., Murrell, P. J., Michael, P. J., Layne, G. D., and Ball, L. A., 2003. Aberrant youth: Chemical and isotopic constraints on the origin of off-axis lavas from the East Pacific Rise, 9 degrees-10 degrees N. Geochem Geophy Geosy 4, -.

Sims, K. W. W., DePaolo, D. J., Murrell, M. T., Baldridge, W. S., Goldstein, S., Clague, D., and Jull, M., 1999a. Porosity of the melting zone and variations in the solid mantle upwelling rate beneath Hawaii: Inferences from U-238-Th-230-Ra-226 and U-235-Pa-231 disequilibria. Geochim Cosmochim Ac 63, 4119-4138.

Sims, K. W. W., Depaolo, D. J., Murrell, M. T., Baldridge, W. S., Goldstein, S. J., and Clague, D. A., 1995. Mechanisms of Magma Generation beneath Hawaii and Midocean Ridges - Uranium/Thorium and Samarium/Neodymium Isotopic Evidence. Science 267, 508-512.

Sims, K. W. W., Goldstein, S. J., Blichert-Toft, J., Perfit, M. R., Kelemen, P., Fornari, D. J., Michael, P., Murrell, M. T., Hart, S. R., DePaolo, D. J., Layne, G., Ball, L., Jull, M., and Bender, J., 2002. Chemical and isotopic constraints on the generation and transport of magma beneath the East Pacific Rise. Geochim Cosmochim Ac 66, 3481-3504.

Sims, K. W. W. and Hart, S. R., 2006. Comparison of Th, $\mathrm{Sr}, \mathrm{Nd}$ and $\mathrm{Pb}$ isotopes in oceanic basalts: Implications for mantle heterogeneity and magma genesis. Earth Planet Sc Lett 245, 743-761.

Sims, K. W. W., Hart, S. R., Reagan, M. K., Blusztajn, J., Staudigel, H., Sohn, R. A., Layne, G. D., and Ball, L. A., 2008. 238U-Th-230-Ra-226-Pb-210-Po-210, Th232-Ra-228, and U-235-Pa-231 constraints on the ages and petrogenesis of Vailulu'u and Malumalu Lavas, Samoa. Geochem Geophy Geosy 9, -.

Sims, K. W. W., Jull, M., and Kelemen, P., 1999b. U-series disequilibria and melt transport in the mantle beneath mid-ocean ridges. Transactions-American Geophysical Union, V22D. 
Smith, W. H. F. and Sandwell, D. T., 1997. Global sea floor topography from satellite altimetry and ship depth soundings. Science 277, 1956-1962.

Spiegelman, M. and Elliott, T., 1993. Consequences of Melt Transport for Uranium Series Disequilibrium in Young Lavas. Earth Planet Sc Lett 118, 1-20.

Stecher, O., Carlson, R. W., and Gunnarsson, B., 1999. Torfajokull: a radiogenic endmember of the Iceland Pb-isotopic array. Earth Planet Sc Lett 165, 117-127.

Stracke, A., Bourdon, B., and McKenzie, D., 2006. Melt extraction in the Earth's mantle: Constraints from U-Th-Pa-Ra studies in oceanic basalts. Earth Planet Sc Lett 244, 97-112.

Stracke, A., Zindler, A., Salters, V. J. M., McKenzie, D., Blichert-Toft, J., Albarede, F., and Gronvold, K., 2003a. Theistareykir revisited. Geochem Geophy Geosy 4, -.

Stracke, A., Zindler, A., Salters, V. J. M., McKenzie, D., and Gronvold, K., 2003b. The dynamics of melting beneath Theistareykir, northern Iceland. Geochem Geophy Geosy 4, -.

Sturm, M. E., Goldstein, S. J., Klein, E. M., Karson, J. A., and Murrell, M. T., 2000. Uranium-series age constraints on lavas from the axial valley of the Mid-Atlantic Ridge, MARK area. Earth Planet Sc Lett 181, 61-70.

Sun, S. S. and Jahn, B., 1975. Lead and Strontium Isotopes in Postglacial Basalts from Iceland. Nature 255, 527-530.

Taras, B. D. and Hart, S. R., 1987. Geochemical evolution of the New England seamount chain: Isotopic and trace-element constraints. Chemical Geology 64, 35-54.

Tepley, F. J., Lundstrom, C. C., Sims, K. W. W., and Hekinian, R., 2004. U-series disequilibria in MORB from the Garrett Transform and implications for mantle melting. Earth Planet Sc Lett 223, 79-97.

Thirlwall, M. F., Gee, M. A. M., Taylor, R. N., and Murton, B. J., 2004. Mantle components in Iceland and adjacent ridges investigated using double-spike $\mathrm{Pb}$ isotope ratios. Geochim Cosmochim Ac 68, 361-386.

Todt, W., Cliff, R. A., Hanser, A., and Hofmann, A., 1996. Evaluation of a 202Pb-205Pb double spike for high-precision lead isotope analysis. In: Basu, A. and Hart, S. R. Eds.), Earth Processes Reading the Isotope Code. AGU.

Tronnes, R. G., Planke, S., Sundvoll, B., and Imsland, P., 1999. Recent volcanic rocks from Jan Mayen: Low-degree melt fractions of enriched northeast Atlantic mantle. J Geophys Res-Sol Ea 104, 7153-7168.

Turner, S., Hawkesworth, C., Rogers, N., and King, P., 1997. U-Th isotope disequilibria and ocean island basalt generation in the Azores. Chemical Geology 139, 145164.

Volpe, A. M. and Goldstein, S. J., 1993. Ra-226 Th-230 Disequilibrium in Axial and OffAxis Midocean Ridge Basalts. Geochim Cosmochim Ac 57, 1233-1241.

Waggoner, D., 1989. An isotopic and trace element study of mantle hterogeneity beneth the Norwegian-Greenland Sea, University of Rhode Island.

White, W. M., Albarede, F., and Telouk, P., 2000. High-precision analysis of Pb isotope ratios using multicollector ICP-MS. Chemical Geology 167, 270-275. 
Widom, E., Carlson, R. W., Gill, J. B., and Schmincke, H. U., 1997. Th-Sr-Nd-Pb isotope and trace element evidence for the origin of the Sao Miguel, Azores, enriched mantle source. Chem Geol 140, 49-68.

Wood, B. J., Blundy, J. D., and Robinson, J. A. C., 1999. The role of clinopyroxene in generating U-series disequilibrium during mantle melting. Geochim Cosmochim Ac 63, 1613-1620. 


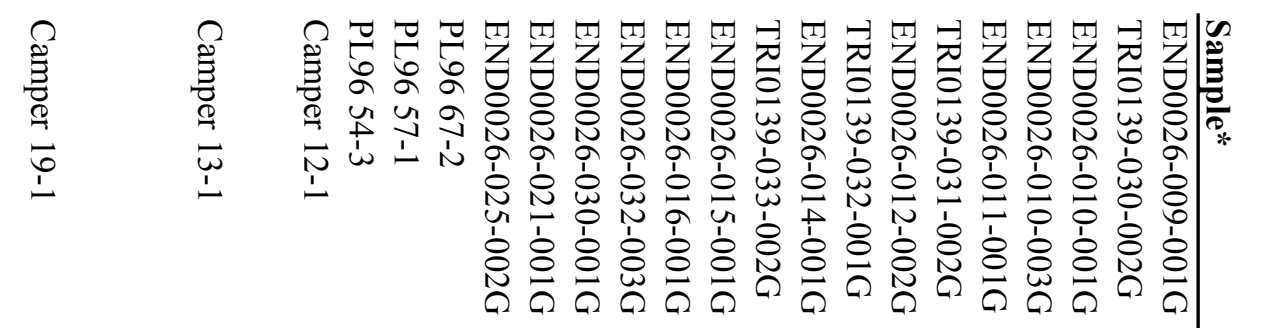

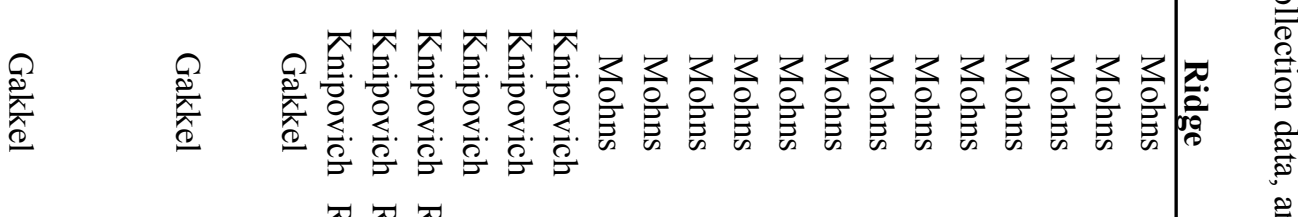

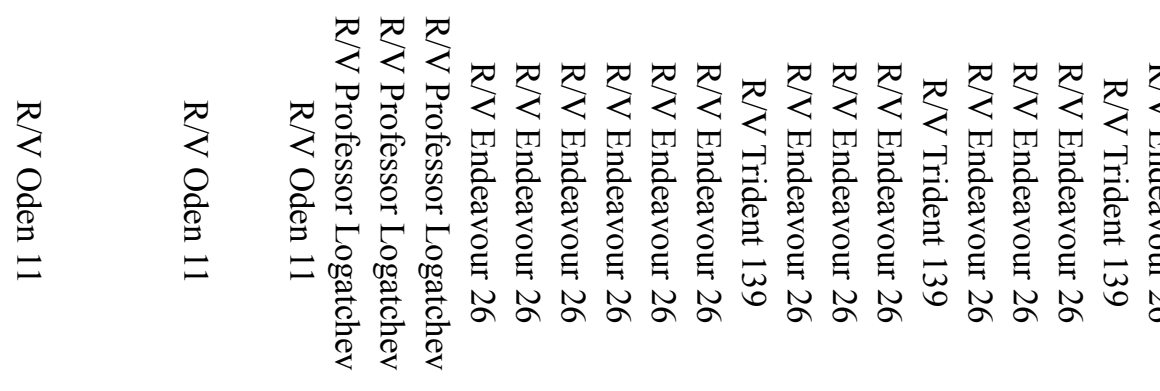

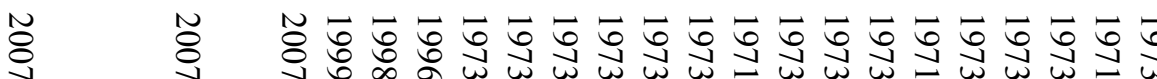

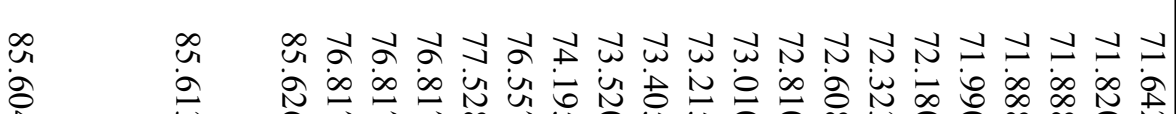

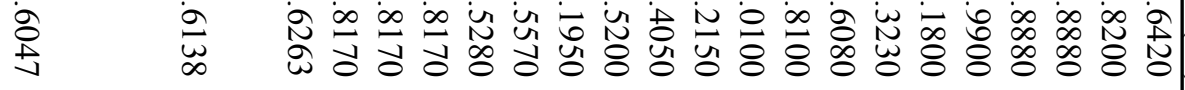

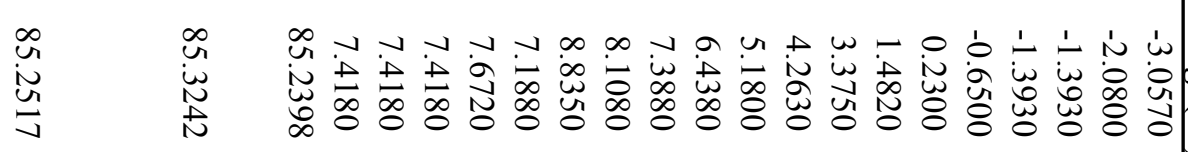

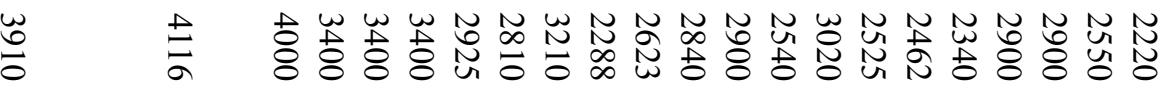

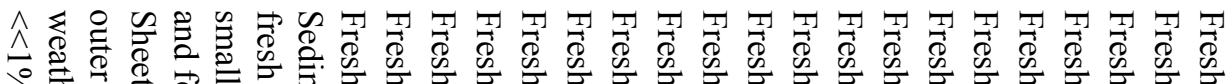

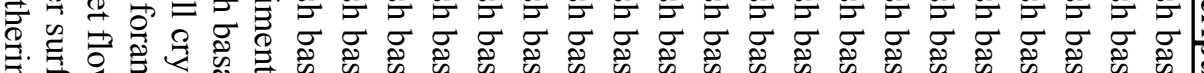

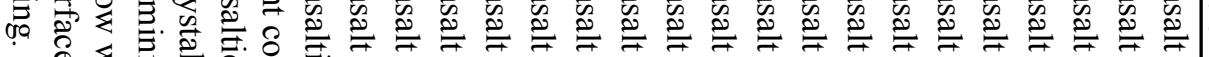
T]

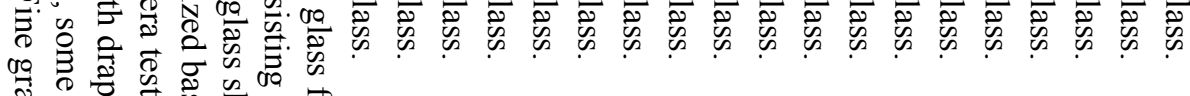

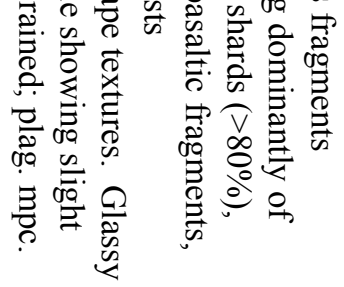




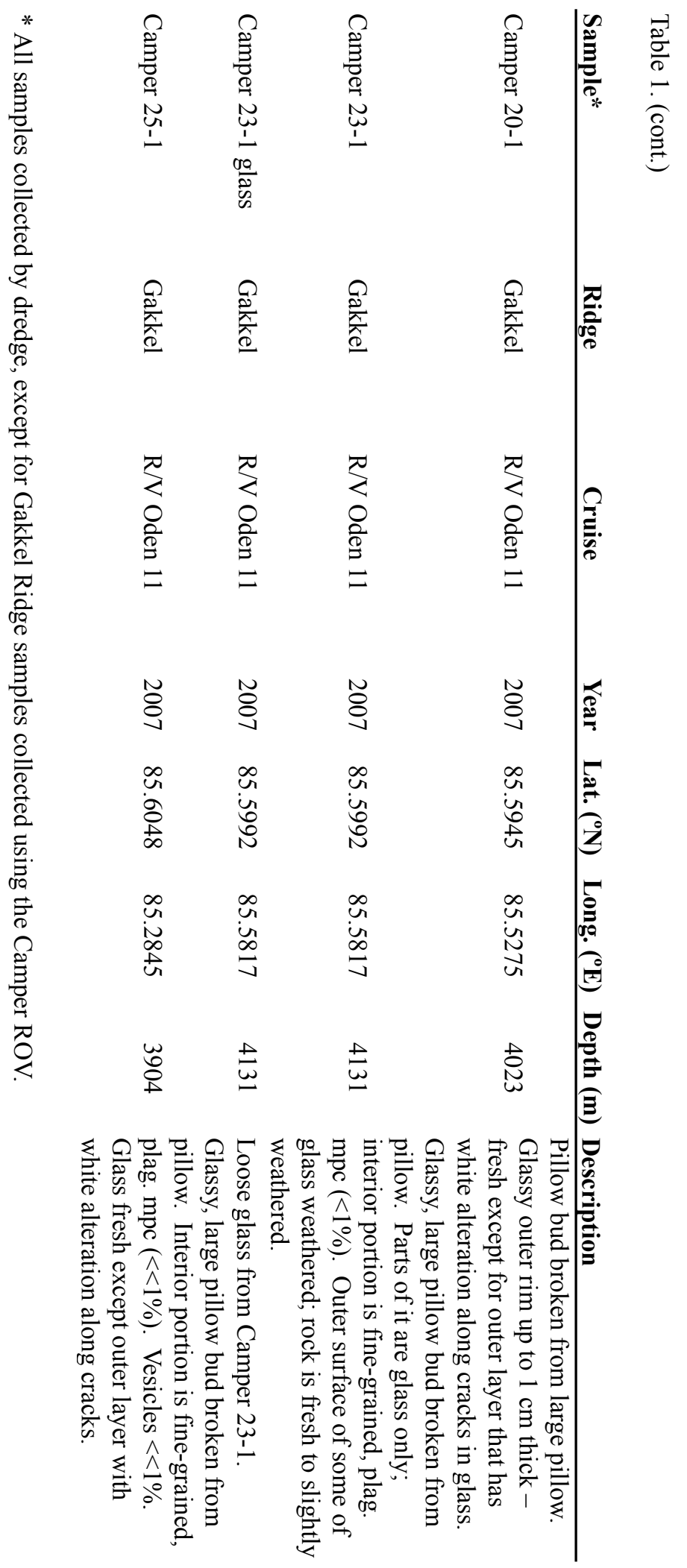




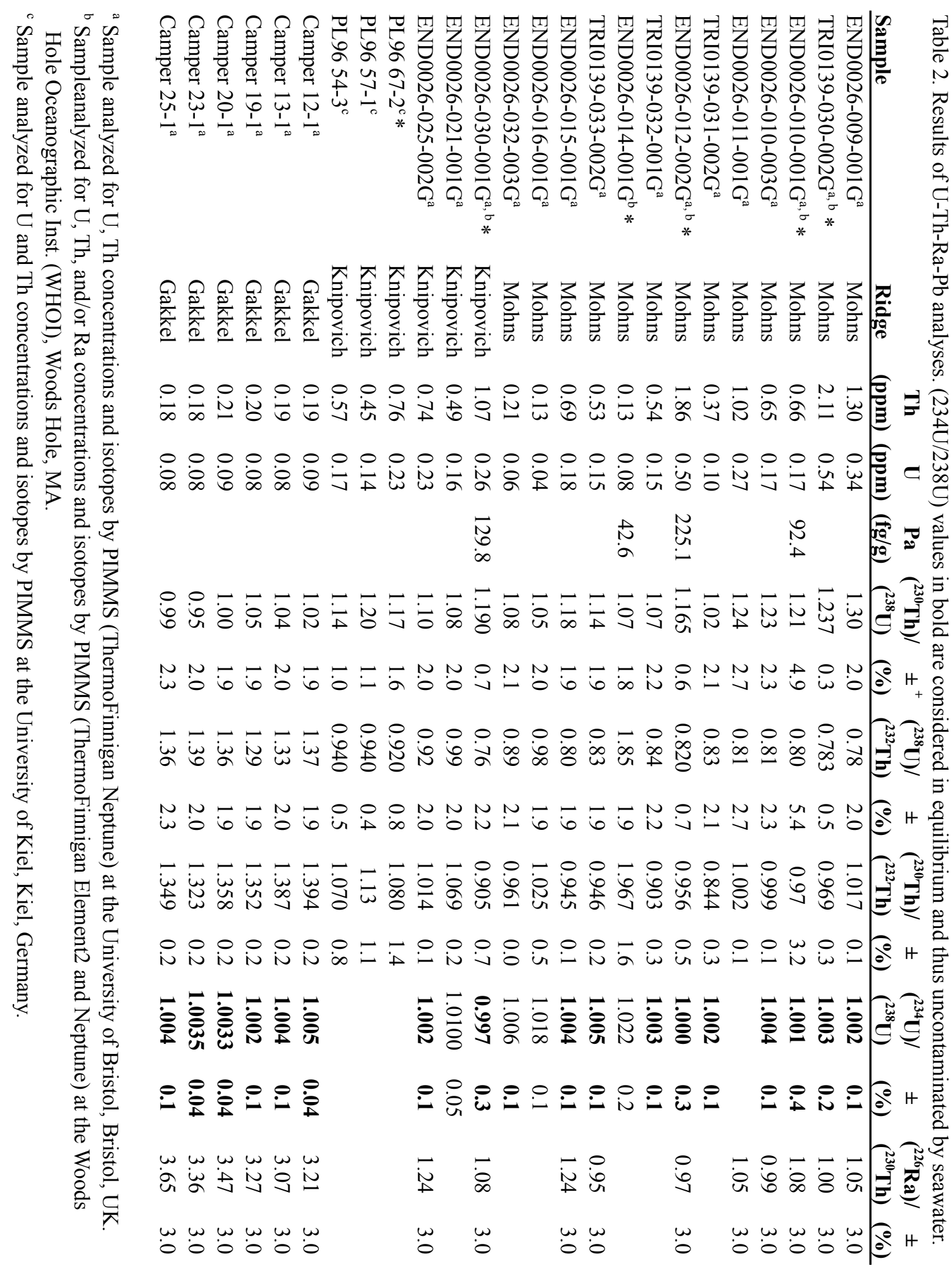




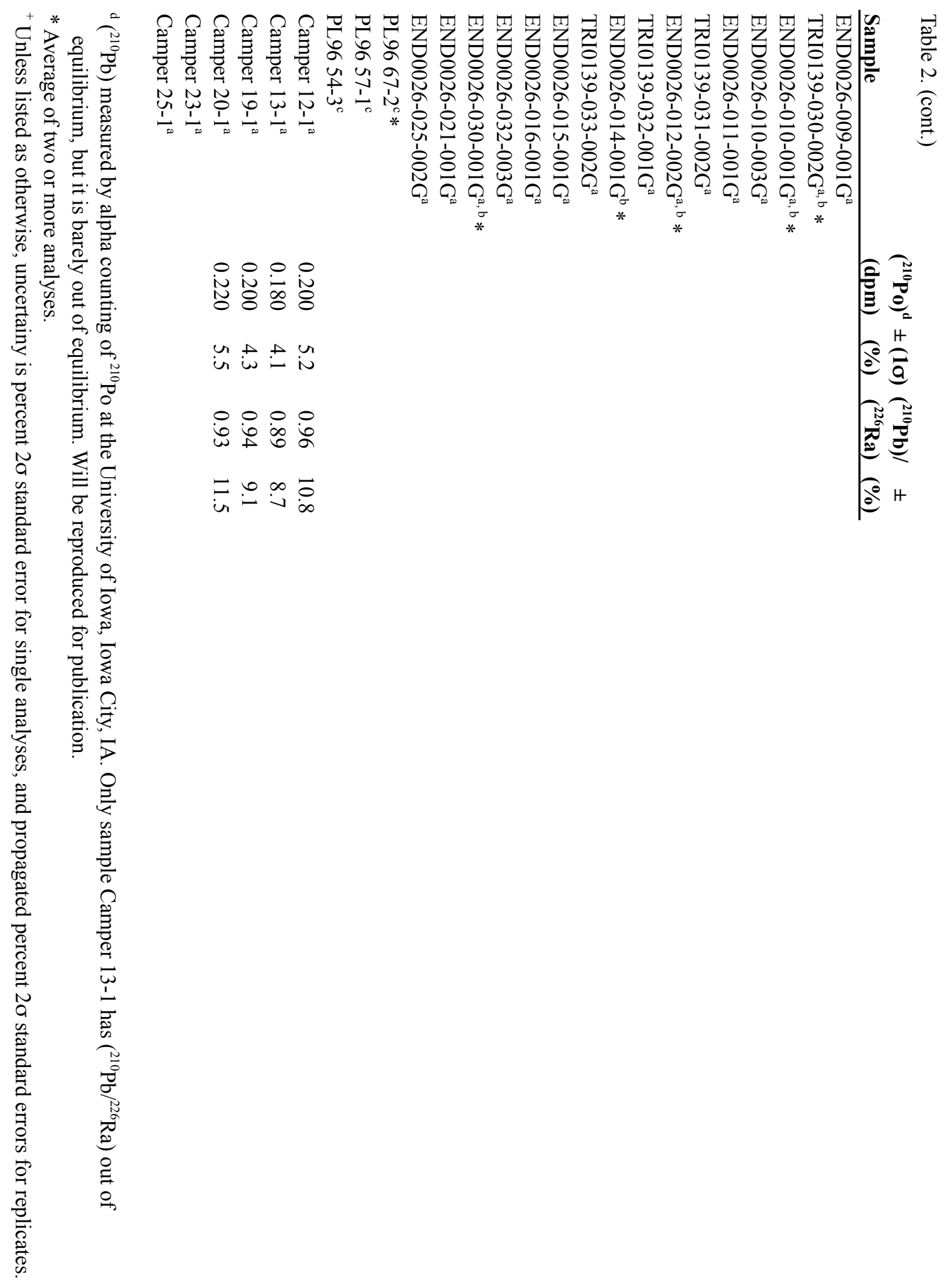




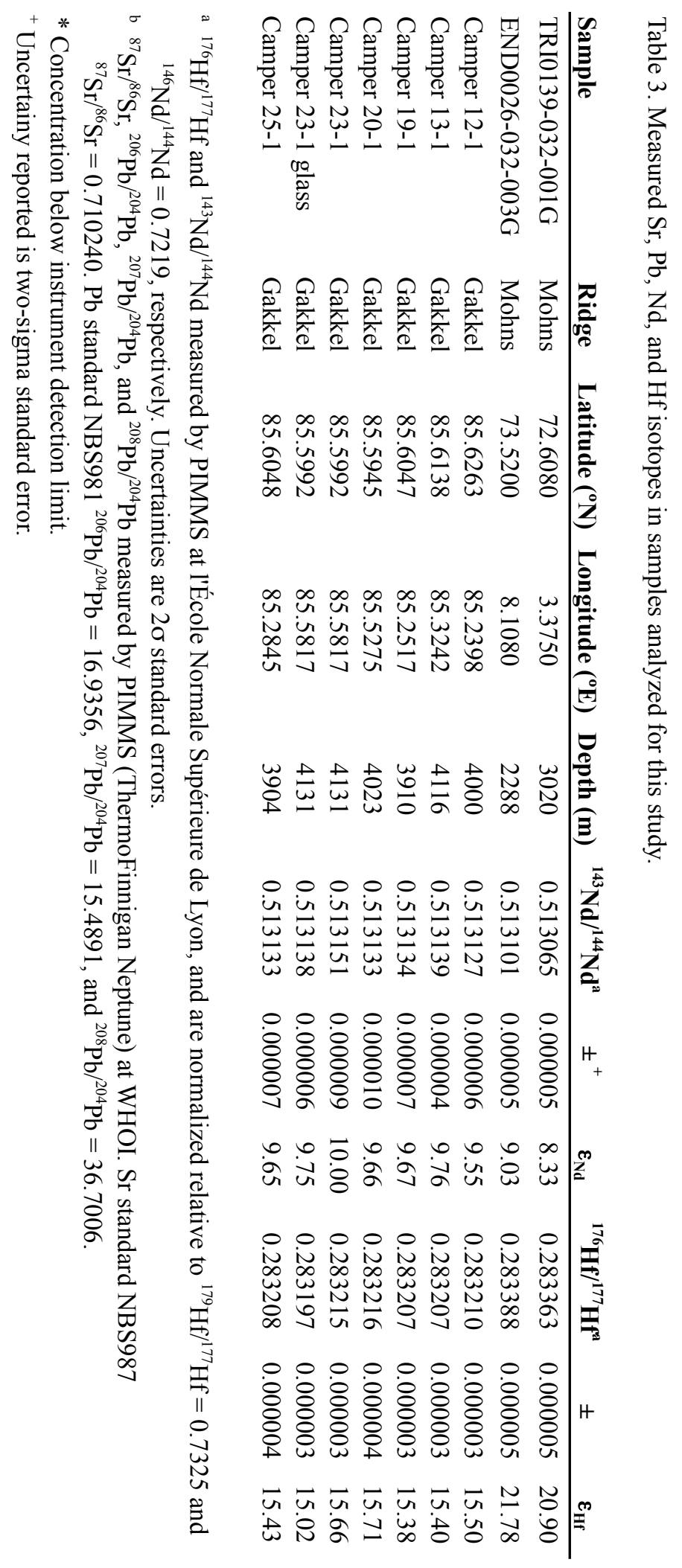




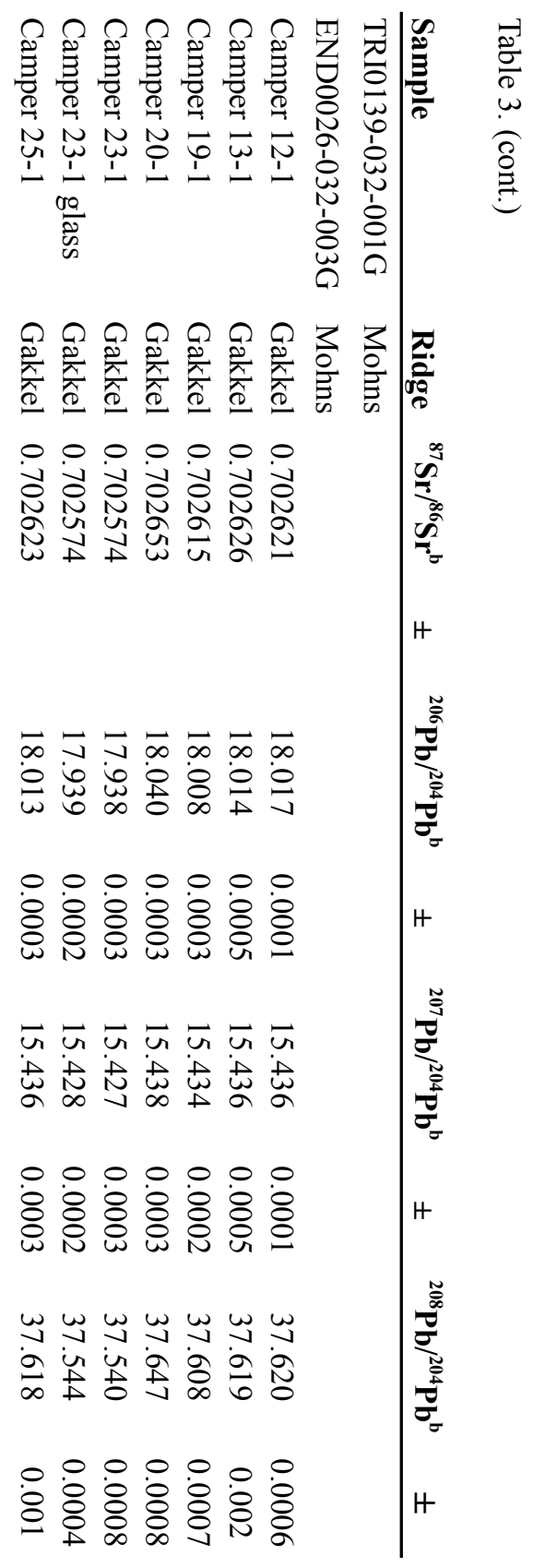

